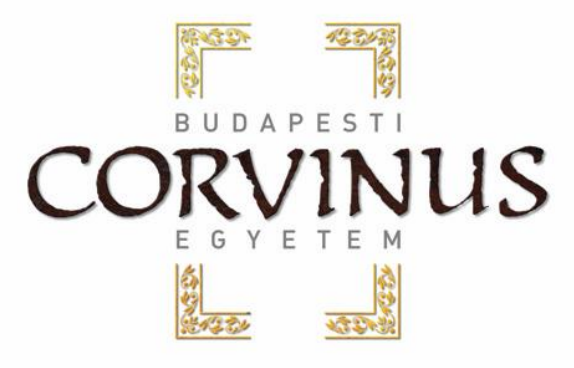

\title{
A SZŐLŐ (VITIS VINIFERA L.) KORAI FENOLÓGIAI VÁLASZADÁSÁNAK MODELLEZÉSE A KUNSÁGI BORVIDÉKEN \\ NÖVÉNYFELVÉTELEZÉSEK, IDŐJÁRÁSI MEGFIGYELÉSEK ÉS REGIONÁLIS KLÍMAMODELL ALAPJÁN
}

Doktori értekezés

Hlaszny Edit

Témavezetők:

Dr. Bisztray György Dénes DSc

egyetemi tanár
Dr. Ladányi Márta PhD egyetemi docens

Budapest 


\section{A doktori iskola}

megnevezése: Kertészettudományi Doktori Iskola

tudományága: Növénytermesztési és Kertészeti Tudományok

vezetője: $\quad$ Dr. Tóth Magdolna

egyetemi tanár, DSc

Budapesti Corvinus Egyetem, Kertészettudományi Kar,

Gyümölcstermö Növények Tanszék

Témavezetők:

Dr. Bisztray György Dénes DSc egyetemi tanár

Budapesti Corvinus Egyetem

Szőlészeti és Borászati Intézet

Szőlészeti tanszék
Dr. Ladányi Márta PhD egyetemi docens

és Budapesti Corvinus Egyetem

Kertészettudományi Kar

Matematika és Informatika Tanszék

A jelölt a Budapesti Corvinus Egyetem Doktori Szabályzatában elöírt valamennyi feltételnek eleget tett, az értekezés mühelyvitájában elhangzott észrevételeket és javaslatokat az értekezés átdolgozásakor figyelembe vette, ezért az értekezés nyilvános vitára bocsátható.

Dr. Tóth Magdolna

Az iskolavezető jóváhagyása
Dr. Bisztray György Dénes

A témavezető jóváhagyása
Dr. Ladányi Márta

A témavezető jóváhagyása

A Budapesti Corvinus Egyetem Élettudományi Területi Doktori Tanácsának 2012. október 2-ai határozatában a nyilvános vita lefolytatására az alábbi bíráló Bizottságot jelölte ki: 
BÍRÁLÓ BIZOTTSÁG:

Elnöke

Kállay Miklós, CSc, BCE

Tagjai

Tóth Magdolna, DSc, BCE

Deák Tamás, $\mathrm{PhD}, \mathrm{BCE}$

Szentteleki Károly, CSc, BCE

Báló Borbála, PhD, SzBKI Eger

Mika János, DSc, Eszterházy Károly Főiskola

Opponensei

Teszlák Péter, PhD, SzBKI Pécs

Puskás János, PhD, NyME

Titkár

Deák Tamás, $\mathrm{PhD}, \mathrm{BCE}$ 


\section{TARTALOM}

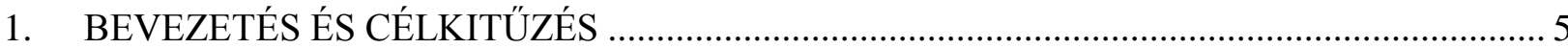

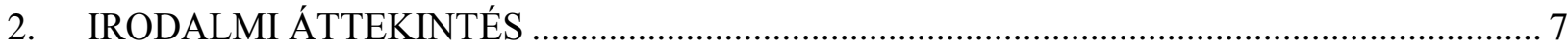

2.1. Az éghajlatváltozás általános tünetei és lehetséges okai ............................................... 7

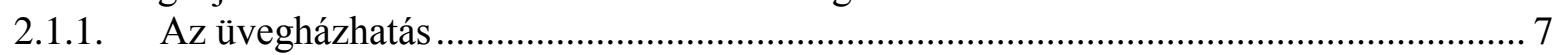

2.1.2. Az üvegházhatás kutatásának előzményei és első eredményei ................................... 8

2.1.3. Az éghajlatváltozás kutatása és eredményei napjainkban ........................................ 10

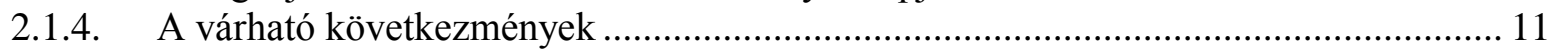

2.2. Az éghajlatváltozás hatása a növények fenológiájára ....................................................... 14

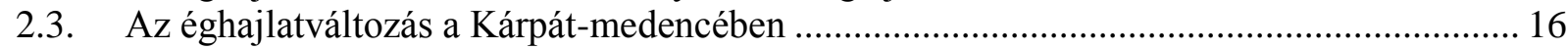

2.4. A szőlő (Vitis vinifera, L.) rügynyugalma, rügyfakadása és virágzása ................................ 17

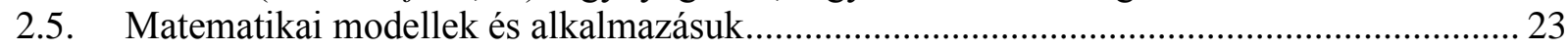

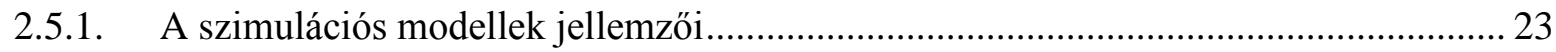

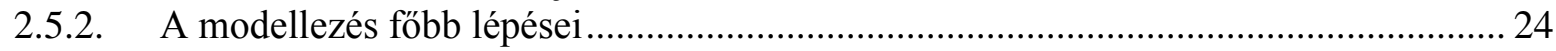

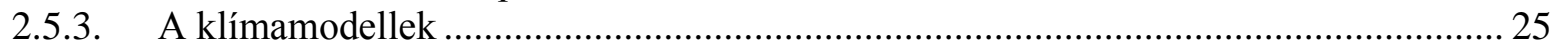

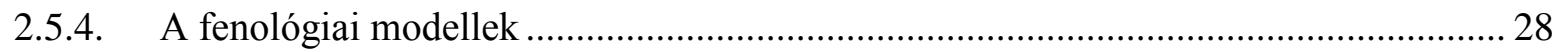

2.6. A klímaváltozásnak a szölötermesztésre gyakorolt hatásai ................................................ 33

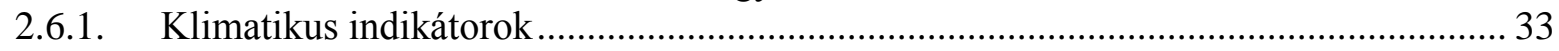

2.6.2. Megfigyelések, prognózisok a világ különböző tájairól......................................... 41

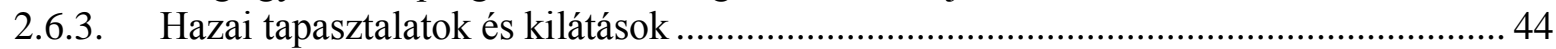

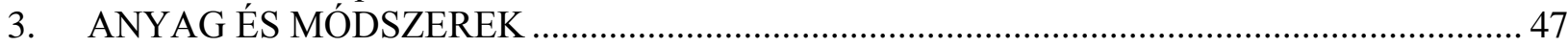

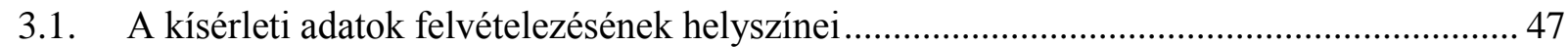

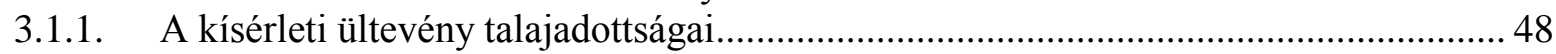

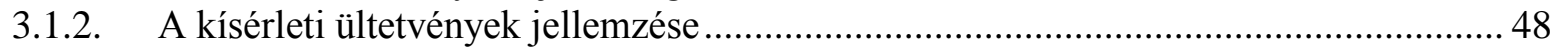

3.1.3. A kísérleti ültetvények kezeltsége …......................................................................... 49

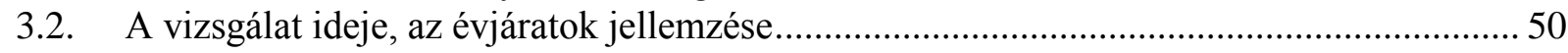

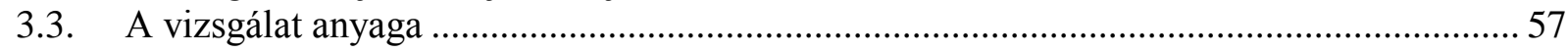

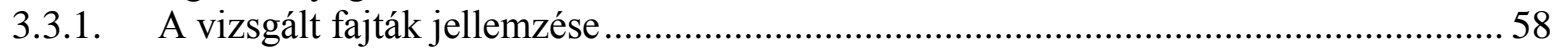

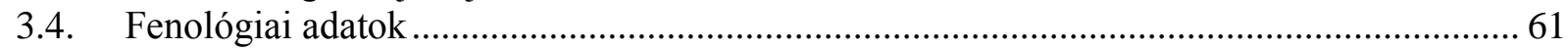

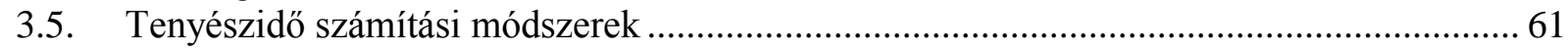

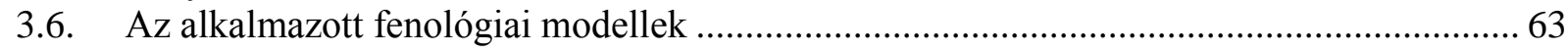

3.6.1. Egyszerü höösszeg modell a rügyfakadás idejének becslésére ................................... 63

3.6.2. Egyszerü höösszeg modell a fővirágzás kezdetének idejére ......................................... 64

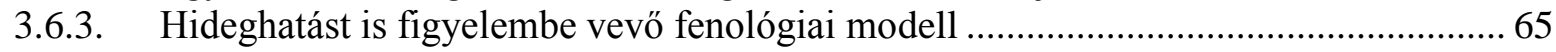

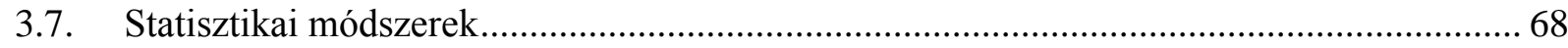

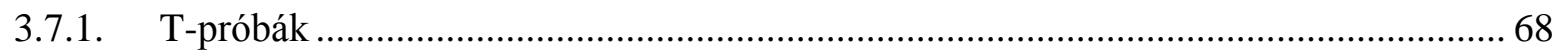

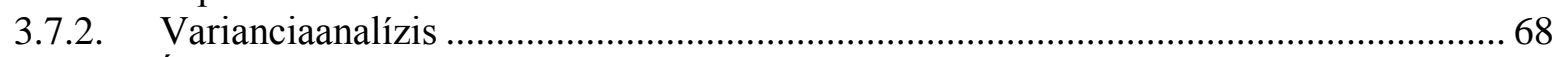

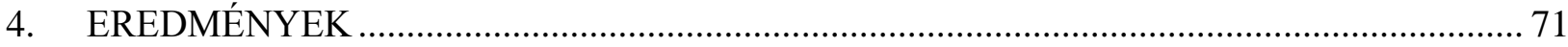

4.1. A klimatikus indikátorok számítási eredményei …….................................................... 71

4.1.1. A klimatikus indikátorok változásai 1977 és 2003 között Kecskeméten ..................... 71

4.1.2. A klimatikus indikátorok a RegCM3.1 regionális klímamodell becslései alapján,

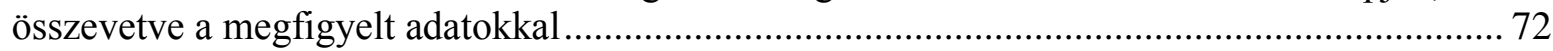

4.2. Tenyészidő számítási módszerek kritikai összehasonlítása .............................................90

4.3. Egyszerü höösszeg modell a rügyfakadás idejének becslésére .......................................91

4.4. Egyszerü höösszeg modell a fővirágzás kezdetének idejére ............................................ 93

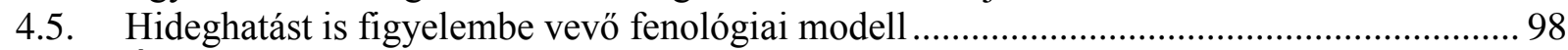

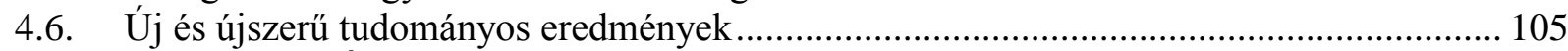

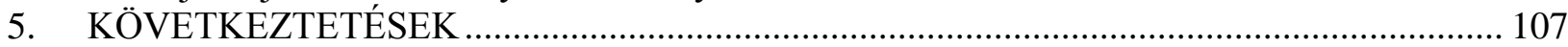

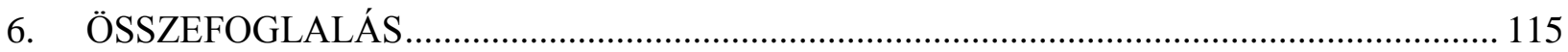

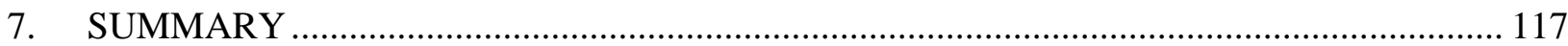

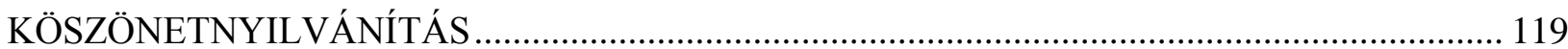

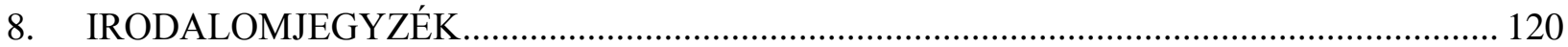

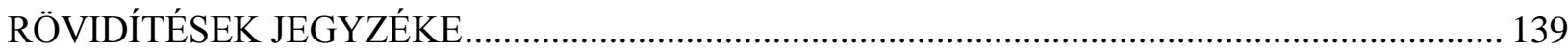

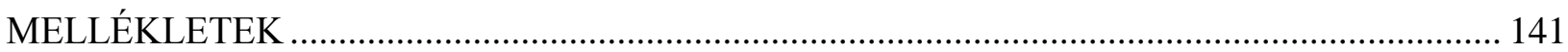




\section{BEVEZETÉS ÉS CÉLKITÜZÉS}

A közelmúltban megkezdődött, és a szakemberek által már bizonyított, az egész Földre kiterjedő éghajlatváltozás hatásai nem kerülik el a mezőgazdaság egyetlen ágazatát, köztük a szőlőtermesztést sem. Az elmúlt 50 év melegedése ugyan kedvező hatással volt a termés és a borok minőségére, azonban számításba kell venni, hogy a szőlőtermesztés földrajzi határai áthelyeződnek, számolni kell az öntözés és a vízhiány problémájával, a fenológiai események időpontjainak változásával és az extrém időjárási jelenségek gyakoribbá és súlyosabbá válásával. Mindez magával hozza az esetleges fajtaváltás, illetve új, ellenálló fajták bevezetésének lehetőségét.

A világ legjelentősebb borvidékein az elmúlt 50 évben a tenyészidőszak átlaghőmérséklete 1,3 ${ }^{\circ} \mathrm{C}$-kal emelkedett, Európában pedig már átlagosan $1,7{ }^{\circ} \mathrm{C}$-os emelkedést mértek a tenyészidőszakban. Magyarországon a klímaváltozás hatására bekövetkező melegedés a hüvösebb klímájú országrészeken kedvező hatással lehet a szőlőtermesztésre, azonban a csapadékhiányos területeken, elsősorban az Alföldön tovább növekedhet az aszálykárok okozta terméskiesés és minőségcsökkenés. Mindez a fenológiai átrendeződéssel a szőlőtermesztés több területének (növényvédelem, fajtaválasztás, kármegelőzés, termesztéstechnológia stb.) szerkezetét átalakíthatja, ami megfelelő válaszadásra kényszeríti a különböző szintü döntéshozókat.

Az éghajlatváltozás lehetséges hatásai iránt ezért erősen megnövekedett az érdeklődés. A szőlő fenológiai szakaszai közül a rügyfakadás és a fővirágzás kezdetének modellezése fontos lehet a sikeres növényvédelem vagy a termesztési technológia tervezésének szempontjából. Munkánk céljául így azt választottuk, hogy megvizsgáljuk néhány Vitis vinifera L. fajta várható válaszadását a Magyarországon várható klimatikus változásokra. Arra kerestük a választ, hogy egyrészt milyen klimatikus indikátorrendszerrel lehetne jellemezni a már lezajlott, illetve a várható változásokat, illetve hogy milyen, a rendelkezésünkre álló adatbázis minőségére és mennyiségére jól alapozható matematikai modellekkel lehetne leírni és vizsgálni a szőlő rügyfakadási és fővirágzási idejének várható módosulását, tudjuk-e igazolni az eltolódást, és ha igen, az milyen irányú és mértékü lesz a közeljövőben.

A Duna Borrégió a Kárpát-medence csapadékban legszegényebb területén helyezkedik el. Megfigyelési adataink erről a szárazságnak és fagyoknak kitett területről, a Kunsági borvidék két termőhelyéről, Helvéciáról és Kecskemétről származnak. Vizsgálatainkba többnyire a nyugati változatcsoporthoz tartozó, a világ legtöbb borvidékén megtalálható fehér- és vörösborszőlő fajtákat, egy pontuszi változatcsoportba tartozó magyar fajtát, illetve egy viszonylag új, hazai nemesítésü, ígéretes fajtát vontunk be. 
A fentiek alapján az alábbi célkitüzéseket fogalmaztam meg:

1. A szakirodalom alapján olyan klimatikus indikátorrendszer összeállítása, amelynek tagjai kis adatigényüek (napi hőmérsékleti és csapadékadatokból előállíthatóak), és amelyek segítségével jól jellemezhetőek a régiók, illetve évjáratok, valamint amelyek megváltozásai a szőlőtermesztésben várhatóan markáns változásokat indukálnak. Az indikátorrendszer alapján a megfigyelt, valamint a RegCM3.1 regionális klímamodell által a 1961-1990-es referencia-időszakra, valamint a 2021-2050 és a 2071-2100-as jövőbeli időszeletre vonatkozó becslések alapján a historikus adatok elemzése és a várható változások megfogalmazása a Kunsági borvidék területére.

2. A szakirodalomban használt tenyészidőszak-számítási módszerek összehasonlítása és javaslat a klímaváltozás esetén is helytálló módszer használatára.

3. A szakirodalomban használt fenológiai modellek felkutatása, ideértve nemcsak a szőlőtermesztésben, hanem egyéb fásszárúakra alkalmazott modelleket is, olyan fenológiai modell vagy modellek megfogalmazása céljából, amely(ek) a szőlö rügyfakadásának, illetve virágzásának idejét megfelelő pontossággal becsüli(k). Esettanulmány végzése a megfogalmazott modellekre a rendelkezésre álló, minél hosszabb fenológiai adatok alapján.

4. A fenológiai modellek lehetőség szerinti továbbfejlesztése.

5. Összehasonlító vizsgálatok a rendelkezésre álló adatok alapján különböző modellekre és fajtákra azzal a céllal, hogy javaslatot tehessünk egy, a vizsgálatba bevont modellek közül a legmegfelelőbbre.

6. Összehasonlító vizsgálatok a fenológiai modellekre a RegCM3.1 regionális klímamodell által a 1961-1990-es referencia-időszakra, valamint a 2021-2050 és a 2071-2100-as jövőbeli időszeletre vonatkozó becslések alapján, a Kunsági borvidéken várható változások megfogalmazása céljából. 


\section{IRODALMI ÁTTEKINTÉS}

\subsection{Az éghajlatváltozás általános tünetei és lehetséges okai}

Ma már bizonyított tény, hogy a Föld éghajlata lassan, de folyamatosan változik. Ennek egyrészt természetes okai vannak. E természetes változás elsősorban a Föld pályájának kismértékủ módosulásával, a Nap kisugárzásának a változásával, a planetáris albedó természetes átalakulásával és a légkör kémiai összetételének természetes változásával függ össze (Salma, 2006). Másfelől az éghajlatváltozáshoz hozzájárulhatnak antropogén hatások, melyek leginkább a fosszilis energiahordozók elégetése és az erdőirtások következtében megnövekedett széndioxid-koncentráció okozta földfelszíni átlaghőmérséklet emelkedésben nyilvánulnak meg. Már a 19. század közepén ismert volt, hogy bolygónk felszínének átlaghőmérséklete lényegesen magasabb, mint ami pusztán a közvetlenül elnyelt napenergia alapján várható lenne (Arrhenius, 1896; Callendar, 1938; Haszpra és Barcza, 2005).

Korábban voltak már jégkorszakok és melegebb periódusok is a Föld történetében. Előfordultak jégkorszakok százezer éves ciklusokban az elmúlt 700 ezer évben, és voltak melegebb periódusok is a jelenleginél, annak ellenére, hogy akkor a széndioxid-szint alacsonyabb volt, mint napjainkban. A mostani felmelegedés kismértékü a korábbiakhoz képest, de a jelentőségét nem szabad lebecsülni, mivel a felmelegedés és a változás túlságosan gyorsan, és a korábbi változásokhoz képest gyakoribb, illetve súlyosabb extremális jelenséggel (viharok, jégverések, aszály, özönvíz, hőhullám stb.) tarkítva történik. Tulajdonképpen ez okozza a fő problémát. Korábban az éghajlat változásainak okai kizárólag természetes eredetüek voltak, de az ipari forradalom nem elhanyagolható változást hozott. A globális felmelegedés jelenleg tapasztalható felgyorsulásának legfőbb oka az üvegházhatású gázok koncentrációjának növekedése a légtérben. A nemzetközi mérési adatok szerint az 1850-es évek óta a Föld globális átlaghőmérséklete $0,76^{\circ} \mathrm{C}$-kal emelkedett (IPCC, 2007; Harnos et al., 2008).

\subsubsection{Az üvegházhatás}

Az üvegházhatás létfontosságú természeti jelenség, mely hozzájárult az élet kialakulásához bolygónkon. Földünk felületére energia érkezik a Napból napfény formájában. A napfény energiájának egy része elsősorban a felhőkről és a levegőből visszaverődik az ürbe (kb. $31 \%$ ), másik része elnyelődik a levegőben (kb. 20\%), a maradék energia eléri a Föld felszínét és elnyelődik benne (kb. 49\%). Az elnyelt energia a Föld felszínét bizonyos hőmérsékleten tartja, aminek következtében a Föld, mint adott hőmérsékletü szilárd test elektromágneses sugárzást bocsájt ki hősugárzás (infravörös sugárzás) formájában. A Föld felszínéről távozó hősugárzást a levegő bizonyos, általában nyomnyi mennyiségben lévő összetevői - vízgőz, szén-dioxid, metán, dinitrogén-oxid, halogénezett szénhidrogének és az ózon - (mintegy 90\%-os valószínűséggel) 
elnyelik. Ezen összetevőket nevezzük üvegházhatású gázoknak. Az üvegházhatású gázok által elnyelt és visszajuttatott energia következtében a Föld felszínén a globális átlaghőmérséklet +15 ${ }^{\circ} \mathrm{C}$, szemben a -18 ${ }^{\circ} \mathrm{C}-\mathrm{kal}$, ami az említett gázok nélkül alakulna ki (Mitchell, 1989; Salma, 2006).

A légköri üvegházhatás antropogén erősödése miatt a 21. század közepére a Föld hőmérséklete magasabbra emelkedhet, mint az emberi történelem során valaha (IPCC, 2007). Ezért az olyan üvegházgázok emelkedő tendenciája felelős, mint a szén-dioxid $\left(\mathrm{CO}_{2}\right)$, a metán $\left(\mathrm{CH}_{4}\right)$, a dinitrogén-oxid $\left(\mathrm{N}_{2} \mathrm{O}\right)$, a halogénezett szénhidrogének és a felszín közelében szaporodó (bár a sztratoszférában csökkenő) mennyiségü ózon $\left(\mathrm{O}_{3}\right)$ (Mitchell, 1989; Mika, 1988, 1991$)(1$. ábra).
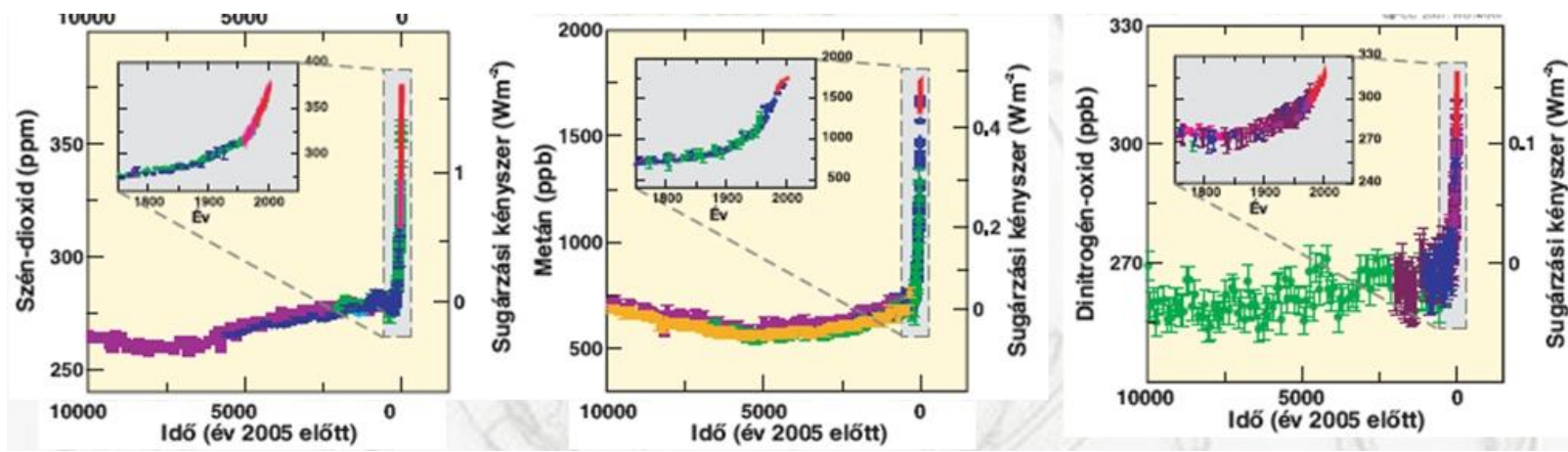

1. ábra: Üvegházhatású gázok változásai: a szén-dioxid, metán és dinitrogén-oxid légköri koncentrációja az elmúlt 10 ezer évben (nagy mezők) és 1751 óta (beszúrt mezők). A mérések jégszelvényekből és légköri mérésekből származnak (IPCC jelentés, 2007)

\subsubsection{Az üvegházhatás kutatásának elözményei és elsö eredményei}

Az első elméletek a 19. század második felében születtek meg a Föld légkörének és hőmérsékletének összefüggéséről (American Institute of Physics, www.aip.com). 1861-ben egy angol fizikus, John Tyndall (1820-1893), felvetette, hogy kapcsolat van a Föld légkörének $\mathrm{CO}_{2}$ szintje és a globális hőmérséklet között. Tyndall egy elméletet alkotott arról, hogy a légkörben az emelkedő $\mathrm{CO}_{2}$ szint több hőenergiát fog fel, mielőtt kisugározná azt az űrbe. Mivel a $\mathrm{CO}_{2}$ egy szigetelő réteget alkot, ezért légköri hömérséklet-emelkedést okoz. Svante August Arrhenius (1859-1927) svéd kémikus elsőként hozta összefüggésbe a levegő széndioxid-tartalmát az atmoszféra átlaghőmérsékletével. Ö volt az első, aki már 1896-ban azt állította, hogy a fosszilis üzemanyagok elégetése végső fokon globális felmelegedést okozhat. Bebizonyította a légköri széndioxid-koncentráció és a hőmérséklet közötti kapcsolatot. Tyndall és Arrhenius voltak az első gondolkodók, akik felvetették a klímaváltozás lehetőségét, mint az ipari forradalom egyik lehetséges következményét. Véleményükkel akkor egyedül maradtak.

A szén-dioxid a legfontosabb emberi tevékenységhez kötődő üvegházhatású gáz. Az első széndioxidkoncentráció-méréseket Charles David Keeling kezdte el 1958-ban Hawaii Mauna Loa nevü hegyén. Róla nevezték tehát el a Keeling-görbét, mely a légkör széndioxid- 
mennyiségét mutatja évekre vonatkoztatva (2. ábra).

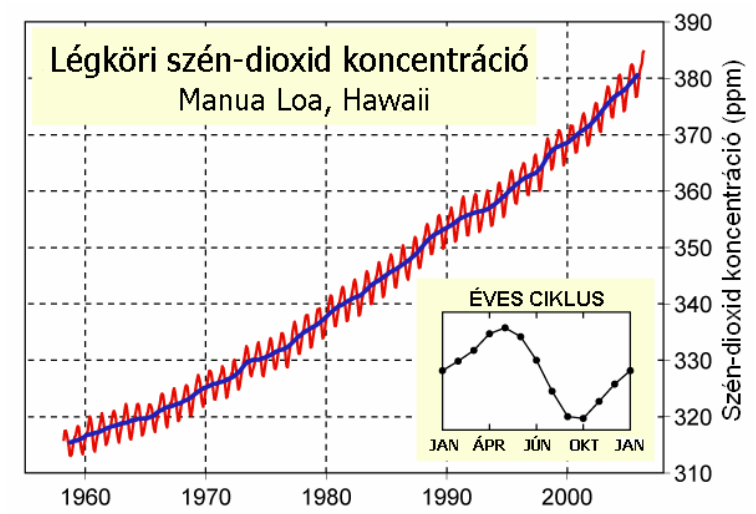

2. ábra: A légköri széndioxid-koncentrációt ábrázoló Keeling-görbe. A kisebbik grafikonon a széndioxid-koncentráció éves változása van feltüntetve.

Forrás: http://upload.wikimedia.org/wikipedia/commons/3/30/Mauna_Loa_Carbon_Dioxidehu.png

A mérések tisztán megmutatják a $\mathrm{CO}_{2}$ növekedését az atmoszférában. Látható továbbá az ábrán az is, hogy a széndioxid-koncentrációjának van egy évszakos ciklusa is, ami a mérsékelt övi területek lombhullató erdeinek asszimilációs ciklusaiból ered.

Az 1960-as és még inkább a 70-es évektöl egyre többen gondolták úgy, hogy a növekvő széndioxid-koncentráció éghajlatváltozást idézhet elő, fontosnak tartották tehát, hogy megfelelő technikai háttérrel rendelkező mérőállomásokat hozzanak létre. A széndioxid-koncentráció mérése kötelező feladatává vált a Meteorológiai Világszervezet (WMO - World Meteorological Organization) levegőszennyezettség-mérő alapállomásainak (www.wmo.int). Magyarországon az Országos Meteorológiai Szolgálat (OMSz) mérőállomásán 1981-ben indult meg a légköri széndioxid-koncentráció folyamatos megfigyelése. 1994 szeptemberében a Magyar-Amerikai Közös Alap támogatásával az OMSz és a NOAA közremüködésével megkezdte működését az első magas mérőtornyos, kifejezetten a regionális bioszféra légköri széncseréjének hosszú távú megfigyelésére létrehozott európai állomás (Haszpra és Barcza, 2005).

1988-ban végre világszerte széles körben elfogadottá vált, hogy az éghajlat melegebb, mint bármilyen periódusban 1880 óta. Az üvegházhatás-elméletet megnevezték, és az ENSZ Környezetgazdálkodási Program, valamint a Világ Meteorológiai Szervezete megalapították a Éghajlatváltozási Kormányközi Testületet (IPCC - Intergovernmental Panel on Climate Change - http://www.ipcc.ch/). Ez a szervezet számos nemzetközi kutatóintézet és egyetem tudósainak munkáját összegyűjtve és szintetizálva megpróbálja az üvegházhatás következményeit előre jelezni létező klímamodellek és irodalmi adatok segítségével. A Testület több mint 2500 tudományos és technikai szakértőt alkalmaz szerte a világon, több mint 60 országból. A tudósok igen távoli kutatási területeken dolgoznak, mint például klimatológia, ökológia, ökonómia, orvostudomány és óceonográfia. Az IPCC a történelem legmesszemenőbben felülvizsgált 
tudományos együttmüködési terve. Az IPCC klímaváltozás-jelentést adott ki 1990-ben (First Assessment Report - FAR), 1995-ben (Second Assessment Report - SAR), 2001-ben (Third Assessment Report-TAR) és utoljára 2007-ben (Fourth Assessment Report-AR4).

\subsubsection{Az éghajlatváltozás kutatása és eredményei napjainkban}

Az IPCC negyedik jelentése szerint a szén-dioxid globális légköri koncentrációja az iparosodás előtti 280 ppm értékről 2005-re 379 ppm-re nőtt. A széndioxid-koncentráció éves növekedési üteme az elmúlt 10 évben magasabb (1995-2005-ös átlagban 1,9 ppm/év) volt, mint a folyamatos közvetlen légköri mérések kezdete óta eltelt teljes időszakban (1960-2005-ös átlagban 1,4 ppm/év), noha a növekedési arány évenként is ingadozik. A sarkokon lévő jégmag buborékaiból kiderült, hogy a levegő CO2-koncentrációja a 280 ppmv értéket soha nem haladta meg az elmúlt 450 ezer év során (1. ábra).

A metán globális légköri koncentrációja az iparosodás előtt kb. 715 ppb értékről az 1990es évek elejére 1732 ppb-re nőtt, és 2005-ben az értéke 1774 ppb. Ez az érték messze meghaladta az utolsó 650000 év természetes tartományát (320-790 ppb), ahogy az szintén a jégszelvényekből meghatározható. A növekedési ütem az 1990-es évek elejétől csökkent. Nagyon valószínü, hogy a metánkoncentráció megfigyelt növekedése antropogén tevékenységeknek, elsősorban a mezőgazdaságnak és fosszilis üzemanyagok felhasználásának tudható be.

A dinitrogén-oxid globális légköri koncentrációja az iparosodás előtti 270 ppb értékről 2005-re 319 ppb-re nőtt. A növekedési ütem 1980-tól nagyjából állandó. A dinitrogénoxidkibocsátás több mint egyharmada antropogén eredetü, amelynek forrása elsősorban a mezőgazdaság (IPCC, 2007).

A Testület valószínünek tartja, hogy az éves üvegházgáz-kibocsátás a kétszeresére fog emelkedni az elkövetkező 50-100 évben (IPCC, 2007).

Az üvegházgázok lényeges tulajdonsága, hogy hosszú légköri tartózkodási idejük miatt a forrásoktól távolra sodródva egyenletesen elkeverednek az egész Föld körül. E tulajdonságuk egyben azt is jelenti, hogy az üvegházhatás erősödése csak a Föld valamennyi szennyező forrására kiterjedő korlátozással mérsékelhető (Mitchell, 1989; Szász és Tőkei, 1997).

Az üvegházhatás mellett még nagyon sokféle erőhatás befolyásolhatja a Föld éghajlatát. Például, amikor a Nap sugárzása erősebbé válik, a bolygó több energiát és meleget kap. Amikor vulkánok törnek ki, port és hamut juttatnak a légkörbe, amely visszaveri a napfényt, ezáltal a bolygó hűlni kezd. Ezeket a hatásokat nevezzük külső erőknek, mivel a bolygó energiaegyensúlyának megváltoztatásával okozzák az éghajlat változását. Az nyilvánvalóan igaz, hogy a múlt klímaváltozásait természeti erők okozták. Az üvegházgázok természetes eredetü növekedése többször okozott klímaváltozást a Föld történetében, de ehhez most minden 
bizonnyal hozzáadódik egy gyorsuló ütemü, antropogén eredetü üvegházgázkoncentrációnövekedés a légkörben (IPCC, 2007).

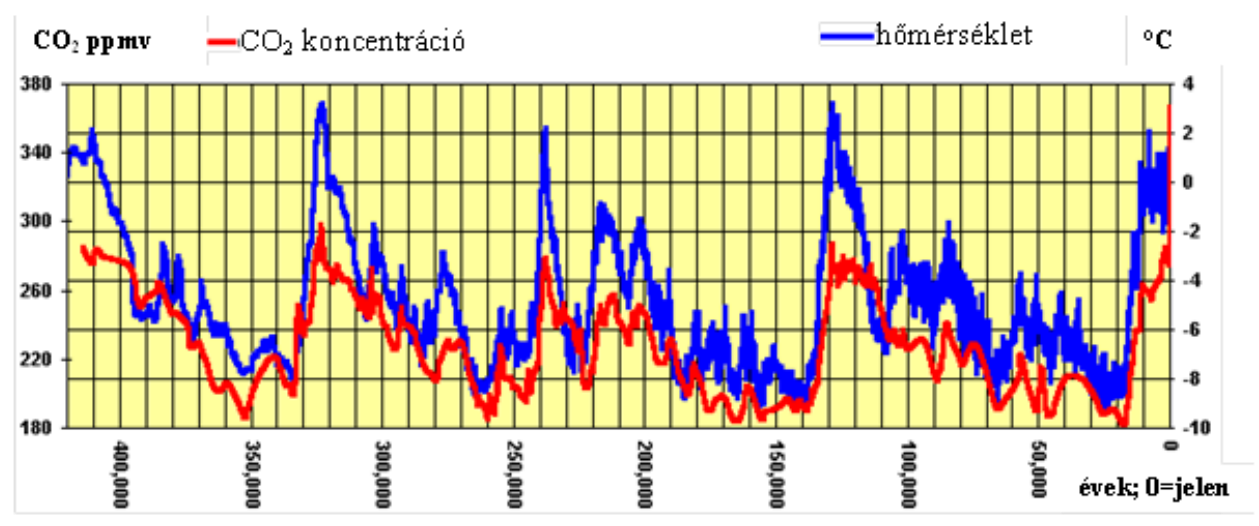

3. ábra: Az Antarktisz jégmintáinak felhasználásával készült széndioxid-vizsgálatok eredménye Forrás: Carbon Dioxide Information Analysis Center http:// cdiac.ornl.gov/

A sarki jégsapkák jégmintáiban megfagyott légbuborékok összetevőinek elemzésével ma már meg tudjuk mondani az elmúlt hőmérséklet-változások mértékét, a naptevékenység szintjét, az üvegházgázok és a vulkáni por légköri mennyiségét (Arctic Climate Impact Assessment (ACIA, 2004 amap.no/acia). Ezekből az adatokból meghatározhatjuk, hogy a hőmérséklet miatt hogyan változott a bolygó múltbeli energia-egyensúlya. Ha a Földtörténet különböző időszakaira pillantunk, láthatjuk, hogy amikor a bolygó hőt kap, a pozitív visszacsatolás fokozza a melegedést. Ezért tapasztaltunk olyan drámai változást a hömérsékletben a múltban is. Éghajlatunk túlságosan érzékeny a hőmérséklet-változásokra. Még azt is számszerüen meghatározhatjuk, amikor figyelembe vesszük a pozitív visszacsatolást, hogy a $\mathrm{CO}_{2}$ szint megkétszereződése $3^{\circ} \mathrm{C}$ körüli hömérséklet-emelkedést okozhat.

Ha a grafikont megnézzük (3. ábra), azt látjuk, hogy a $\mathrm{CO}_{2}$-mennyiség hogyan változott a Föld történetének elmúlt 400 ezer évében, továbbá láthatjuk a napjainkban (a nulla értéknél) gyorsuló ütemben emelkedő széndioxid-szintet (piros vonal), valamint az ehhez szorosan kötődő hőmérséklet-változást (kék vonal). Ebből a grafikonból láthatjuk, hogy a széndioxidkoncentráció a légkörben az elmúlt 420 ezer évben nem szárnyalta túl a mai szintet és valószínüleg az elmúlt 20 millió évben sem (NOAA - National Oceanic and Atmospheric Administration), pedig azt a kutatók már bizonyosan tudják, hogy voltak a mostaninál melegebb periódusok a Föld története során. Az elörejelzések szerint a széndioxid-koncentráció a jelenlegi 490 ppmv-ről 2100-ig 1260 ppmv értékre emelkedik (IPCC, 2007).

\subsubsection{A várható következmények}

A fentiekben bemutatott természetes és antropogén hatások feltehetőleg az alábbi események bekövetkezését eredményezi (IPCC, 2007): 
- A sarki jég olvadása és az óceánok kiterjedése. Ez áradásokat okoz a partközeli területeken, a mélyföldeken és a folyók deltájában. Néhány kis sziget talán teljesen eltűnhet az áradások következtében. A sarki jégsapkákban a fagyott állapotban lévő széndioxid a jég elolvadásával tovább növeli a légkör széndioxid-tartalmát, és fokozza a felmelegedést.

- Az Atlanti-óceán sókoncentrációjának csökkenése módosítja a hideg és meleg öböláramlatokat, mely végső soron nagy valószínűséggel jégkorszakot is okozhat.

- A trópusi viharok és ciklonok száma, súlyossága növekszik.

- A mezőgazdasági területeken áradás és erózió várható. Ez károsítja a talajt, és csökkenti a terméseredményt. A csapadék eloszlása egyenetlenné válik.

- Nagy változások az ökoszisztémában és csökkenő biodiverzitás.

- A vízkészletek elpárolgása ivóvízhiányt okoz.

- A sós tengervíz behatolása a talajvíz zónába.

- A szélsőségesebb időjárás melegebb, szárazabb nyarakat és hidegebb teleket okoz.

- Több fertőző betegség megjelenése, mivel a környezet kedvezőbbé válik a kórokozók és olyan veszélyes rovarok számára, mint a malária szúnyog.

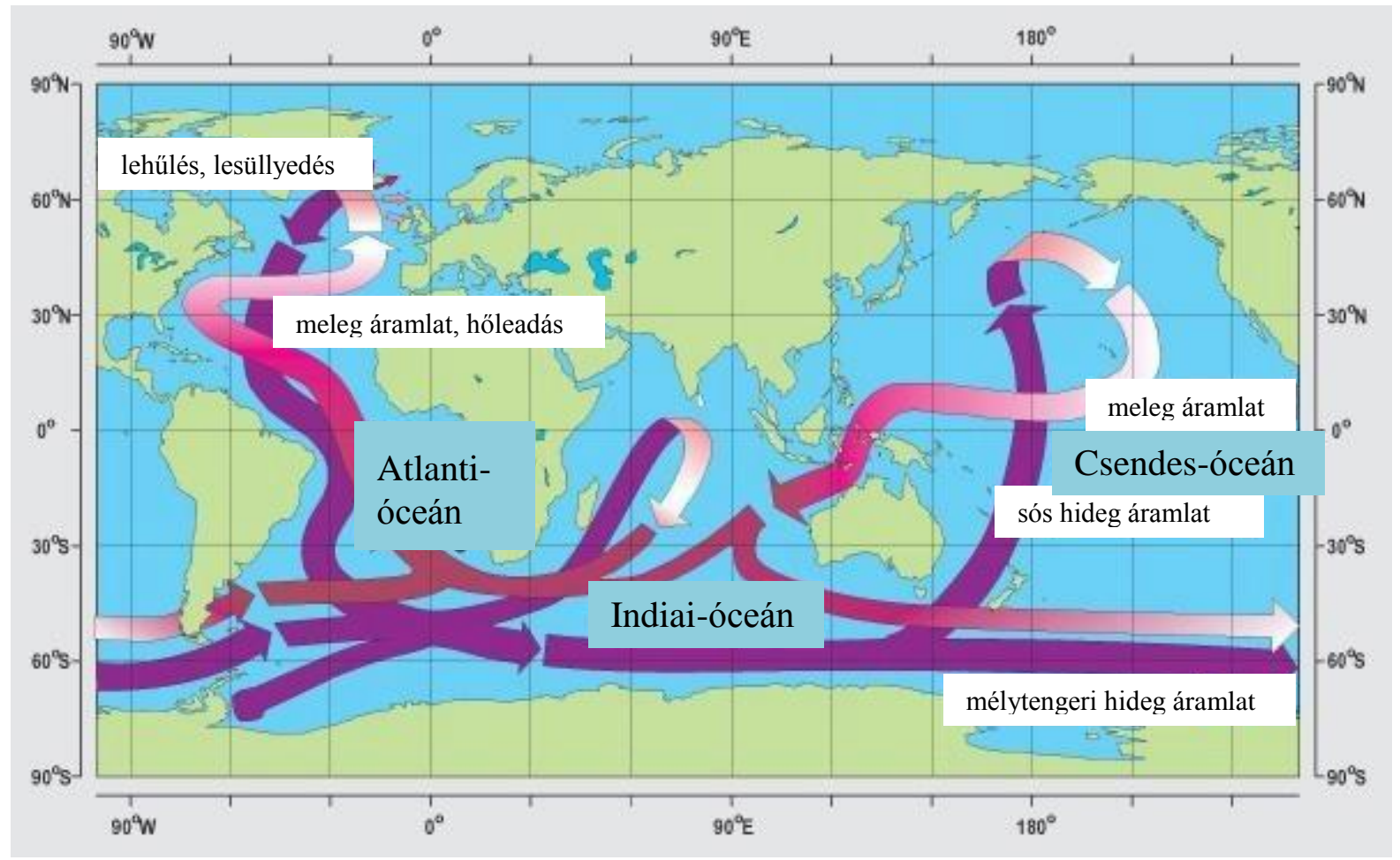

4. ábra: Az óceánok főbb áramlatai a Földön. A sötétebb sávok jelölik a hideg áramlatokat, a világosabbak a meleget (http://www.windows2universe.org).

2004-ben, mint biztonsági kockázat foglalkoztatta az éghajlat kutatóit és a közvéleményt a sajtóban közzétett Pentagon-jelentés (Schwartz és Randall, 2003), ami arról az elméleti 
lehetőségről szól, hogy az ún. óceáni szállítószalag (Broecker, 1987; Czelnai, 1999) leállhat, s ennek nyomán a Föld éghajlata a melegedésből egyszerre csak lehülésbe, esetleg jégkorszakba fordulhat. A melegedő éghajlat egyik következménye ugyanis a sarki jégsapkák és a sarkköri gleccserek olvadása. Ez nemcsak tengerszint-emelkedést okozhat, hanem befolyásolhatja az óceáni áramlatokat is (4. ábra), ezáltal a légkörünket. Amikor ugyanis a tengervíz megfagy a sarki jéghegyek körül, kiveti magából a sót. A hideg vízréteg a tengeri jég alatt sósabbá és sürübbé válik, így elég nehézzé válik, ahhoz, hogy lesüllyedjen. Az Arktisznál a hideg víz lesüllyed a Norvég-Grönland-tengerbe. Ennek következtében a hideg víz kicserélődik a sekély, meleg vízre, mely északkelet felé mozog a trópusokról. Ha azonban a sarki jég és a gleccserek elolvadnak, édesvíz jut az óceánba. Az édesvíz felhígítja a tengervizet, csökken a sókoncentráció, ezáltal a keverékvíz nem elég sürü, hogy lesüllyedjen. Így fékeződhetnek, sőt leállhatnak az óceáni áramlatok, ami hatással van a hőcserére a pólusok és a trópusok között, kiváltva ezzel egy kisebb jégkorszakot az Európai kontinensen.

Bár ilyen horderejű kérdésnél különösen szükséges megvárni, amíg a vizsgálatokat több mühelyben is elvégzik, néhány újabb vizsgálat nyomán megkockáztatjuk, hogy a jégkorszak bekövetkezése ma kevésbé valószínü, mint ahogy ezt néhány évvel ezelött gondoltuk. Eddig ugyanis egyik klímamodell sem mutatott teljes leállást a melegedéssel párhuzamosan. Továbbá nem tudjuk, hogy a tízezer évnél régebbi korokban, amikor a pár száz év alatti többfokos felmelegedésekkel és lehülésekkel párhuzamosan gyakran volt a mainál sokkal gyengébb az áramlás, a vízkörzés gyengülése oka vagy éppenséggel következménye volt-e a változásoknak. Végül, egy olyan kísérletben, ahol mesterségesen „kapcsolták ki” a hőszállítást (Wood et al., 2003), a jelen éghajlathoz képest ugyan $10{ }^{\circ} \mathrm{C}$-ot meghaladó lehűlés alakult ki az Atlanti-óceán északi medencéiben, ám a kontinenseken a csökkenés jóval kisebb volt, Közép-Európában például csak 2-3 ${ }^{\circ} \mathrm{C}$. Amikor pedig az óceáni szállítást a fokozódó melegedéssel párhuzamosan „kapcsolták ki” akkor a mainál hidegebb klíma az Atlanti-óceán térségére korlátozódott. Eközben a szárazföldek felett az üvegházhatás fokozódása miatti melegedés hatása erősebb volt, mint a szállítószalag leállása miatti lehűlés (Wood et al., 2003; Bartholy és Mika, 2005).

Az IPCC 1996-os jelentése szerint az éghajlatot befolyásoló antropogén hatások körébe immár bele kell érteni a troposzferikus aeroszolokat is a továbbra is domináns üvegházgázok mellett. A légkör cseppfolyós és szilárd alkotórészei az elmúlt évtizedekben - föleg az iparosodott területek tágabb környezetében - korlátozták az üvegházgázok okozta felmelegedést. Az előrejelzések szerint a szulfát-aeroszolok a jövőbeni globális átlagában kb. egyharmadával fékezhetik az üvegházhatás erősödését (NASA, Earth Observing System, 1999; Haywood és Bouchet, 2000; Szász és Tőkei, 1997). Az aeroszolokhoz történt antropogén hozzájárulások (elsősorban szulfát, szerves szén, feketeszén, nitrát és por) együttesen hűtőhatást fejtettek ki, 
összesen -0,5 W/m2 közvetlen sugárzási kényszer és - $0,7 \mathrm{~W} / \mathrm{m} 2$ közvetett felhö-albedó kényszer mértékben. Ezek a kényszerértékek a jobb közvetlen helyszíni, müholdas és felszínbázisú méréseknek, továbbá az átfogóbb modellezésnek köszönhetően ma már jobban érthetők, mint a 3. IPCC jelentés idejében, de a sugárzási kényszerben továbbra is jelentős a bizonytalanság. Az aeroszolok befolyásolják a felhők élettartamát és a csapadékképződést is.

$\mathrm{Az}$ éghajlati rendszer melegedése tehát az IPCC mai álláspontja szerint vitán felül áll, mivel ez ma már nyilvánvaló a globálisan átlagolt levegő- és óceán-hőmérséklet emelkedéséből, a hó- és jégtakaró kiterjedt olvadásából és a globális átlagos tengerszint-emelkedés megfigyeléseiböl (IPCC, 2007).

\subsection{Az éghajlatváltozás hatása a növények fenológiájára}

A világ számos országában kutatók és kutatócsoportok foglalkoznak az éghajlatváltozás lehetséges következményeinek feltárásával. Erre a célra az egyik legalkalmasabb, leginkább kifejező indikátor-jellegü tudományterület a fenológia, mely a növények és állatok életének körforgásában a környezet (különösen a hőmérséklet és a csapadék évszakos változásai) által befolyásolt periodikus eseményeket tanulmányozza. Réaumur (1735) vetette fel először, és azóta számos kutatócsoport bizonyította, hogy a növények fenológiai jelenségeire hatással vannak a meteorológiai feltételek (Rosenzweig et al, 2007; Bonhomme, 2000; Chuine és Cour, 1999; Chuine et al., 1998, 1999; Cleland et al., 2007; Menzel et al., 2006, Bradley et al., 1999).

Az időjárás és fenológia kapcsolatát vizsgáló publikációk egybehangzóan állítják, hogy a hőmérséklet a fő mozgatója számos növény fejlődési folyamatainak. A magasabb hőmérséklet általában gyorsítja a fejlödést és így korábban lép a növény a következő egyedfejlödési stádiumba. Az IPCC 2001-es jelentése szerint 1901 és 2000 között megközelítőleg 0,6 ${ }^{\circ} \mathrm{C}$ fokkal emelkedett a földi átlaghőmérséklet (IPCC 2001). A 2007-es jelentésben viszont a frissített 100 éves lineáris trend (1906-2005) már 0,74 ${ }^{\circ} \mathrm{C}$ átlaghőmérséklet emelkedést jelez. Az összes hőmérséklet-emelkedés az 1850-1899 közötti időszaktól a 2001-2005 közötti időszakig 0,76 ${ }^{\circ} \mathrm{C}$ (IPCC, 2007).

Az éghajlat melegedésének a természetes és kultivált ökoszisztémákra gyakorolt hatásait a világ számos részén (Európa, Amerika, Ázsia) megfigyelték, és különböző hosszúságú fenológiai idősorok felhasználásával igazolák (Penuelas és Finella, 2001; Walther et al., 2002; Parmesan és Yohe, 2003; Root et al, 2003). A publikációk főként az elmúlt 20 évről szólnak, amikor már kifejezetten a klímaváltozás kutatásához kapcsolódó monitoring rendszereket alkalmaztak a világ számos pontján, de igazi kincsnek számítanak a hosszú idősorok feldolgozásán alapuló jelentések (Arakawa, 1955, 1956; Beaubien és Hamann, 2011). A növényfenológiai változások szoros összefüggésben vannak a megfigyelt hőmérsékletváltozással, melynek az 1970-es éveket követő megfigyeléseiről egyre gyakrabban számolnak be 
(Menzel és Fabian, 1999; Menzel és Estrella, 2001; Larcher, 1995; Keeling et al. 1996; Myneni et al., 1997; Price és Waser, 1998; Dunne et al., 2003; Aerts et al., 2004). Sparks és munkatársai (2009) megjegyzik, hogy 1990 és 2008 között a fenológia kifejezésnek a klímaváltozással kapcsolatos használata a tudományos közleményekben meghétszereződött. Hughes (2000), Wuethrich (2000), McCarty (2001), továbbá Walther és munkatársai (2001) szerint a klímaváltozás hatása a virágzásfenológiára nemcsak közvetlenül az egyes növényfajokra hat, hanem megváltoztathatja a szélesebb közösségi szerkezetet és az ökoszisztéma müködését is. Geber és Dawson (1993), Bradshaw és McNeilly (1991), Holfman és Parson (1997), RodriguezTrellis és Rodriguez (1998), de Jong és Brakefield (1998) szerint az éghajlat melegedése különböző válaszidejü evolúciós módosulásra késztetheti az élő rendszereket. A klímaváltozás közvetlenül megváltoztathatja a növény alkalmazkodóképességét (Galen és Stanton, 1991, 1993; Wookey et al. 1993), valamint módosíthatja a növények szaporodási sikerét és fenológiáját (Hughes, 2000; Beattie et al., 1973; Schemske, 1977; Gross és Werner, 1983; Lacey és Pace, 1983; Schmitt, 1983; English-Loeb és Karba, 1992; Peterson, 1997; Bishop és Schmeske, 1998).

Khanduri és munkatársai (2008) az őszi és a tavaszi fenológiai változásokat több mint 650 mérsékelt övi növényfaj esetében megfigyelték. Eredményeik szerint a 20. század végéig átlagosan 1,9 nappal korábban indul meg a tavaszi fejlődés, és 1,4 nappal későbben következnek be az őszi események minden egyes évtizedben. Ezáltal átlagosan 3,3 nappal megnövekedett a vegetációs időszak évtizedenként. Bár az őszi fenológiai változásokról a tavasziakkal szemben kevesebb elérhető információnk van (Khanduri et al., 2008), néhányan az őszi fenológiai események késését figyelték meg. Európában és Japánban például a levélszínváltozás 0,3-1,6 napos késést mutat dekádonként, ahol a vegetációs időszak hossza 3,6 nappal növekedett dekádonként az elmúlt 50 évben (Menzel és Fabian, 1999; Menzel, 2000; Matsumoto et al., 2003). Általában a melegebb ősz korábbi gyümölcséréshez vezet, viszont késik a levelek öregedése (Cleland et al, 2007).

A kutatók számos eszközt és módszert alkalmaznak, hogy faj szintü megfigyelésekre alapozva igazolják a fenológiai változásokat (Menzel et al., 2006; Sparks és Carey, 1995; Parmesan és Yohe, 2003; Root et al, 2003; Walther et al., 2002), hogy távérzékeléssel kövessék az ökoszisztémák produktivitásának változását (Myneni, et al., 1997; Zhou et al., 2001), valamint megfelelő monitoring rendszerrel mérjék a légköri széndioxid-mennyiséget és a fotoszintetikus aktivitást (Randerson et al., 1999; Keeling et al., 1996). Ezek közül az elmúlt években számos tanulmányban dokumentálták a kora tavaszi fenológia és az emelkedő hőmérséklet közötti korrelációt, de eltérő hatásokat találtak a tenyészidőszak végére vonatkozóan (Estrella és Menzel, 2006; Menzel, 2003). A klímaváltozás hatását vizsgáló kutatások között kiemelt szerepe van a növekvő átlaghömérséklet, a csapadékeloszlás változása, valamint az 
emelkedő széndioxid-koncentráció fajokra és ökoszisztémákra, mint rendszerekre gyakorolt hatásának is (Cleland et al., 2007; Dunne et al., 2003; Penuelas et al., 2004; Arft et al., 1999). A melegedéssel egyidőben számos esetben a növények növekedésének és a virágzásának gyorsulását dokumentálták (Dunne et al., 2003, Arft et al., 1999, Price és Waser, 1998), különösen a kora tavaszi virágzású fajok esetében (Dunne et al., 2003). Érdekes módon a tenyészidőszakban később fakadó növények esetében arról is beszámoltak, hogy azok vagy nem reagálnak szignifikánsan a melegedésre (Dunne et al., 2003), vagy késik a fenológiai fázisuk, különösen, ha a hőmérséklet fiziológiai türöképességük fölé emelkedik (Sherry et al., 2007).

\subsection{Az éghajlatváltozás a Kárpát-medencében}

Európában a római korok óta többször történt klímaváltozás napjainkig, kisebb -nagyobb jégkorszakok melegebb időszakokat váltottak. A „római klímaoptimum” során Németország, Hollandia és Anglia területén is meghonosították a szőlőtermesztést a rómaiak. Eközben a Kárpát-medencében az észak-olaszországihoz hasonló éghajlat uralkodott. A népvándorlás egyik kiváltó okának tekintik az éghajlat hidegebbé válását, mely időszak során a szőlőtermesztés is visszaszorult. A 9. században ismét egy melegebb időszak következett, amivel beköszöntött a „középkori éghajlati optimum”. Az éghajlat szárazabbá, de jóval enyhébbé vált, a szőlőtermesztés északi határa pedig egészen a Baltikumig terjedt. Ennek a szőlő számára kedvező klímának vetett véget a 14. században bekövetkezett „kis jégkorszak”, ami lényegében a 19. század végéig tartott. Ezután ismét a melegedő éghajlat tette kedvezőbbé az életet. Az ipari forradalmat követően a megnövekedett légköri szén-széndioxid koncentráció tovább növelte az átlaghőmérsékletet, mely napjainkban is folytatódik (Zanathy, 2008).

Az Európai Unió „Alkalmazkodás a klímaváltozáshoz” címü Zöld Könyve szerint (2007, http://eur-lex.europa.eu/LexUriServ/site/hu/com/2007/com2007_0354hu01.pdf)

Európa legsérülékenyebb területe Dél-Európa és a Földközi-tenger teljes medencéje, ahol a jelentős hőmérséklet-emelkedés és a csökkenő csapadékmennyiség együttes hatása olyan területeken jelentkezik, melyeken már most is vízhiánnyal küzdenek. Magyarország e régió határán, a Kárpát-medence a nedves óceáni, a száraz kontinentális és a nyáron száraz, télen nedves mediterrán éghajlati régiók határán helyezkedik el (Harnos et al., 2008). E határzónában pedig az éghajlati övek kismértékű eltolódása is oda vezethet, hogy a Kárpát-medence „átcsúszik” a három hatás valamelyikének egyértelmű uralma alá (Szász és Tőkei, 1997). A 2007-es ENSZjelentés szerint Magyarország a klímaváltozás természeti sokszínűségre gyakorolt hatása szempontjából a világ egyik legsérülékenyebb állama (SEG, 2007). Harnos és munkatársai (2008) szerint a hazai átlaghőmérséklet emelkedése másfélszer gyorsabb, mint a globális felmelegedés üteme. Elsősorban a nagyobb szárazság és az édesvízkészletek relatív hiánya miatt lehetnek negatív következményei Magyarországra nézve a globális felmelegedésnek. 
Gyakoribbá válhatnak az extrém időjárási események is, és ugyancsak kedvezőtlen, hogy a kevés csapadék is egyenetlenebbül oszlik majd el: várhatóan egyre gyakrabban zúdul ránk kiadós eső, ami sokkal nagyobb károkat okozhat, mint az eddigi csapadékhullás. Nálunk az Alföldön figyelhető meg leginkább ez a jelenség, ahol új növény- és rovarfajok telepednek meg, míg mások az életfeltételek módosulása nyomán visszaszorulnak. A növényzet megritkulása nyomán a homokos talaj kevésbé áll ellen a szél erejének, ami viszont a sivatagosodási folyamat felgyorsulását idézheti elő. Az ELTE Meteorológiai Tanszékén a század utolsó harmadára futtatott klímamodellek, többek között az alábbi Magyarországon várható változásokra hívják fel a figyelmünket (Bartholy et al., 2004, 1. táblázat):

- növekvő középhömérséklet: nyáron akár $4-5{ }^{\circ} \mathrm{C}$-os is, de több mint $2,5-3{ }^{\circ} \mathrm{C}$ minden évszakban és régióban;

- téli-tavaszi csapadéknövekedés akár $30 \%$-ot is meghaladóan, nyári-őszi csapadékcsökkenés 20-30\%-os mértékben;

- évente 140-150 napos $25^{\circ} \mathrm{C}$ feletti napi maximum hőmérséklet.

1. táblázat: Az időjárási rekordok előfordulásának várható gyakorisága 2071 után az 1961-90-es bázisidőszakhoz viszonyítva (Pongrácz és Bartholy, 2007)

\begin{tabular}{|l|c|}
\hline \multicolumn{1}{|c|}{ Extrém indikátorok } & $\begin{array}{c}\text { A változás várható } \\
\text { mértéke }\end{array}$ \\
\hline A $25{ }^{\circ} \mathrm{C}$ feletti napi maximumhőmérsékletü napok száma & $+39 \%$ \\
\hline A $30^{\circ} \mathrm{C}$ feletti napi maximumhőmérsékletü napok száma & $+91 \%$ \\
\hline A $35{ }^{\circ} \mathrm{C}$ feletti napi maximumhömérsékletü napok száma & $+250 \%$ \\
\hline A 0 ${ }^{\circ} \mathrm{C}$ alatti napi maximumhömérsékletü napok száma & $-75 \%$ \\
\hline A $-10{ }^{\circ} \mathrm{C}$ alatti napi minimumhömérsékletű napok száma & $-83 \%$ \\
\hline A $0{ }^{\circ} \mathrm{C}$ alatti napi minimumhőmérsékletű napok száma & $-65 \%$ \\
\hline A $20^{\circ} \mathrm{C}$ feletti napi minimumhömérsékletü napok száma & $+625 \%$ \\
\hline
\end{tabular}

\subsection{A szőlő (Vitis vinifera, L.) rügynyugalma, rügyfakadása és virágzása}

A szőlőtőke évi biológiai ciklusa a nedvkeringés tavaszi megindulásától a szőlő vegetációs nyugalmának a befejezéséig tart, s ezek a ciklusok évről évre ismétlődnek. A biológiai ciklus alatt a vegetatív periódust, azaz a tenyészidőszakot értjük, valamint az ezt követő vegetációs nyugalmat. A biológiai ciklus a termőhelyen a biológiai nulla fok feletti hőmérsékleten indul meg. A szakirodalomban a biológiai nulla fokot széles körben $+10^{\circ} \mathrm{C}$-ban jelölik meg, de természetesen ez az érték egy durva becslés. A vegetációs periódus a rügyfakadástól a lombhullásig, a vegetációs nyugalom pedig a lombhullástól a következő évi rügyfakadásig tart (Kozma, 1991).

A szőlőtőke vegetációs nyugalmi periódusa lombhullástól a tavaszi nedvkeringés megindulásáig tart. A szőlő szerveinek fiziológiai nyugalmi ideje nem teljesen azonos, a gyökérzetnek például nincs mély fiziológiai nyugalmi ideje. A rügyekre jellemző a legjobban a 
szervi fiziológiai nyugalom, s ezt a tulajdonságot a szőlő hosszú evolúciós folyamat során szerezte meg a külső környezet hatására. Ezáltal kedvező körülmények esetén sem fakadnak ki a rügyek a tél folyamán (Kozma, 1991).

A rügynyugalom definíciója még vitatott, mivel ez alapvetően egy változó folyamat: átmenet az alig észlelhető növekedési állapotból az igazi téli nyugalomba, majd a kényszernyugalomba (Chuine és Cour, 1999). A rügynyugalom Perry (1971) szerint egy fiziológiai állapot, melyet rendszerint csökkent növekedési rátájú periódusként definiálnak, kisszámú vagy semmilyen sejtosztódással, és amelyben a pozitív hidegösszegek szükségesek a növekedés és a fejlödés újrakezdéséhez (Perry, 1971). Számos kísérlet bizonyítja, hogy a rügynyugalmat megtörheti a $10^{\circ} \mathrm{C}$ alatti pozitív hidegösszeg az ősz és a tél folyamán (Perry, 1971, Hänninen és Backman, 1994; Sarvas, 1974), de az ezt megelőző periódus hatását a rügynyugalomra és a rügyfakadásra korábban nemigen tanulmányozták (Mauget, 1977, Champagnat, 1983). Pedig a rügyfakadást megelőző nyár hőmérsékleti összege is hatással lehet a nyugalmi állapot intenzitására és a rügyfakadás időpontjára (Chuine és Cour, 1999).

A vegetációs nyugalom periódusát a mélynyugalom (endodormancy) és a kényszernyugalom (ecodormancy) időszakokra bonthatjuk, az elsőben a növény fiziológiailag meghatározott módon éli nyugalmát, a másodikban a még nem megfelelő környezeti tényezők tartják fent ezt az állapotot (Lang, 1987). Tavasszal a fakadó rügyböl, mely a szőlő esetében összetett rügy, hajtás fejlődik, majd ennek hónaljában kifejlődik a tenyészidőszak folyamán a következő évi alvó vagy látens rügy. Tavasszal és kora nyáron körülbelül 10 levélkezdemény fejlődik minden rügyben, míg a förügyekben a virágzatkezdemény is kialakul (Boss et al., 2003). A nyár közepén a rejtett rügyek a feltételes nyugalom fázisába lépnek (paradormancy), melyben a rügyfakadást elnyomják bizonyos más növényi szövetekből származó faktorok, elsősorban a tenyészőcsúcsból származó auxin hormon (Lang, 1987; Lavee és May, 1997). Az ősz folyamán csökkenő fotoperiódus és hőmérséklet indukálja a rügyek mélynyugalmát (endodormancy), mialatt a rügyfakadást hormonális faktorok gátolják (Lang, 1987, Lavee és May, 1997). Ez Magyarországon általában augusztus 10-e és szeptember eleje között következik be (Kozma, 1991). Ahhoz, hogy a rügyek a nyugalmi ciklus során tovább fejlődjenek, elegendő hideg hőösszegnek kell érnie a rügyeket, ami végül a mélynyugalmi állapot megszünéséhez vezet (Lavee és May, 1997, Dookazalian, 1999). Ez Magyarországon általában december közepérevégére bekövetkezik. December végétől a szőlőtőke a kényszernyugalmi (ecodormancy) szakaszba kerül, és ha a hideg hőösszeg előfeltételei teljesültek, akkor a rügyfakadás kedvező időjárási feltételek mellett már megtörténhet, mivel ekkor a gátló faktorok immár a környezeti feltételek, a túl alacsony hőmérsékletek (Lang, 1987; Or et al., 1999, Kozma, 1991). 
A nyugalmi időszak szabályozása egyes (pl. hideg telü vagy trópusi éghajlatú) régiókban nagyon fontos a kereskedelmi szőlötermesztés és más mérsékletövi gyümölcstermő növények szempontjából (Saure, 1985). Hideg telü területeken a hidegösszegek hamar összegyülnek, ezáltal a mélynyugalmi állapot korán megszünik. A tartósan alacsony hőmérséklet fagykárokat okozhat, mely a termésmennyiség csökkenéshez vezethet, valamint a fagyvédelmi módszerek megnövelik a termelés költségeit (Cattiavelli és Bartlet 1992, Kadir és Proebsting, 1994). Ezért ezeken a területeken fagytürő fajták alkalmazása javasolt, melyek a kedvezőtlen körülmények között is képesek alkalmazkodni és megfelelöen fejlödni (Or, 2009).

2. táblázat: A szőlőrügyek nyugalmi periódusának szakaszai és ezek főbb jellemzői (Bényei et al. 1999)

\begin{tabular}{|c|c|c|c|c|c|c|}
\hline & \multirow[b]{2}{*}{$\begin{array}{l}\text { A szakasz } \\
\text { neve }\end{array}$} & \multicolumn{3}{|c|}{ A gátlás } & \multirow[b]{2}{*}{ Időszak } & \multirow{2}{*}{$\begin{array}{l}\text { A fakadáshoz } \\
\text { szükséges idő } \\
\text { (h) } 25^{\circ} \mathrm{C}-\text { os } \\
\text { vízben. }\end{array}$} \\
\hline & & megnevezése & kiváltó oka & eredete & & \\
\hline 1. & $\begin{array}{l}\text { A nyugalmat } \\
\text { megelőző } \\
\text { fázis }\end{array}$ & $\begin{array}{l}\text { csúcsdominanci } \\
\text { a, korrelációs } \\
\text { gátlás }\end{array}$ & Auxin (IES) & $\begin{array}{c}\text { tenyészöcsúcsok } \\
\text {, nyári rügy, } \\
\text { levelek }\end{array}$ & $\begin{array}{c}\text { júniustól } \\
\text { augusztus első } \\
\text { dekádjáig }\end{array}$ & 200 \\
\hline 2. & $\begin{array}{c}\text { A } \\
\text { nyugalomba } \\
\text { lépés fázisa }\end{array}$ & $\begin{array}{l}\text { endogén } \\
\text { nyugalom }\end{array}$ & $\begin{array}{c}\text { Abszcizinsav } \\
\text { (ABS) } \\
\text { növekvő } \\
\text { koncentrációja }\end{array}$ & kifejlett levelek & $\begin{array}{l}\text { augusztus } 10- \\
\text { től szeptember } \\
\text { elejéig }\end{array}$ & $200-300$ \\
\hline 3. & $\begin{array}{l}\text { A nyugalom } \\
\text { fázisa }\end{array}$ & $\begin{array}{l}\text { endogén } \\
\text { nyugalom }\end{array}$ & $\begin{array}{c}\text { Abszcizinsav } \\
\text { (ABS) } \\
\text { maximális } \\
\text { koncentrációja }\end{array}$ & kifejlett levelek & $\begin{array}{l}\text { augusztus } \\
\text { végétől } \\
\text { november } \\
\text { végéig }\end{array}$ & $480-1800$ \\
\hline 4. & $\begin{array}{c}\text { A } \\
\text { nyugalomból } \\
\text { ébredés } \\
\text { fázisa }\end{array}$ & $\begin{array}{l}\text { endogén } \\
\text { nyugalom }\end{array}$ & $\begin{array}{c}\text { Abszcizinsav } \\
\text { (ABS) } \\
\text { csökkenő } \\
\text { koncentrációja }\end{array}$ & kifejlett levelek & $\begin{array}{c}\text { október eleje- } \\
\text { közepétől } \\
\text { decemberig }\end{array}$ & $\begin{array}{l}\text { A fázis elején } \\
\text { 1300-1500, a } \\
\text { fázis végén } \\
500-600\end{array}$ \\
\hline 5. & $\begin{array}{l}\text { A nyugalom } \\
\text { utáni fázis }\end{array}$ & $\begin{array}{c}\text { exogén } \\
\text { nyugalom }\end{array}$ & $\begin{array}{c}\text { alacsony } \\
\text { hőmérséklet }\end{array}$ & $\begin{array}{l}\text { időjárás } \\
\text { (éghajlat) }\end{array}$ & $\begin{array}{l}\text { októbertől } \\
\text { márciusig, } \\
\text { áprilisig }\end{array}$ & $0-200$ \\
\hline
\end{tabular}

Enyhe telü vidékeken az elegendő mennyiségü hidegösszegek hiánya a fő gátja a kereskedelmi minőségű szőlő előállításának. A hosszú nyugalmi időszak tünetei a megkésett és alacsony százalékú rügyfakadás, a késleltetett virágzási szezon, a rendellenes érés, a csökkent terméshozam, a növekedési erély gyors csökkenése (Dookazalian és Williams, 1995; Lavee és May, 1997; Dookazalian, 1999). Ezeken a területeken a sikeres termeléshez elengedhetetlen a nyugalmi szakasz kémiai vagy fizikai megszakítása (Erez, 1987; Erez és Lavee, 1974). 
$\mathrm{Az}$ áttelelö vagy alvó (látens) rügyeknek a fejlödéstörténet folyamán a környezeti viszonyok függvényében kialakult, s genetikusan meghatározott sajátságos fejlődési ciklusa, azon belül nyugalmi periódusa van, $\mathrm{s}$ a periódus jól jellemezhető fázisokra tagolódik (2. táblázat).

A nyugalmi periódus hossza fajok és fajták szerint változó. A korán fakadó és érő európai, továbbá a kelet-ázsiai fajok rügyei öntözéses viszonyok között korán, már augusztus elején belépnek a nyugalmi fázisba. Ugyanezeknek a fajoknak a fajtái száraz viszonyok között később kezdik vegetációs nyugalmi fázisukat. A későbbi érésủ nyugat-európai és a pontuszi fajták csak augusztus második felében lépnek a mélynyugalmi fázisba (Kozma, 1991).

A rügyek nyugalmi fázisa a korai fakadású és érésű fajtáknál rövidebb, viszont a kései és igen kései érésü fajtáknál jóval hosszabb. A trópusi származású fajok rügyei nem lépnek a nyugalom fázisába, nem vesztik el növekedési és fakadási képességüket, mint a mérsékelt övi fajták. Ez is bizonyítja, hogy a rügynyugalom képessége a hidegebb klímaviszonyokhoz való alkalmazkodás eredménye (Kozma, 1991).

A rügyfakadás a szőlő vegetációs periódusának kezdeti szakasza, ideje több tényezőtől függ, például a szőlőfajok és -fajták sajátságaitól, környezeti és termesztési viszonyoktól, a tőkék fiziológiai és egészségi állapotától, a rügyek helyzetétől, a tél és a tavasz hőviszonyaitól. Közelítőleg azonban elmondhatjuk, hogy a rügyfakadás akkor indul meg, amikor az adott fajta számára összegyülik a szükséges hatásos hőösszeg. Ez fajtánként változó érték, sőt klónjaik esetében is vannak eltérések (Chuine et al., 2003).

Amikor a tavaszi nedvkeringés megindul, a szőlő föld feletti részei megtelnek vízzel és a megvágott szőlővesszőn keresztül láthatóvá válik a könnyezési nedv. A rügyek duzzadni, a hajtáskezdemények sejtjei osztódni kezdenek. A megduzzadt rügy pikkelylevelei kinyílnak, megjelenik közöttük a primordiális szerveket védö rügygyapot, majd áthatol azon a hajtáskezdemény csúcsi része, megjelennek az első levélkezdemények, s ezzel befejeződik a rügyfakadás (5. ábra). Ennek ideje Magyarországon április közepe-vége. A szőlő összetett rügyeiből többnyire csak a központi vagy förügy hajt ki (Kozma, 1991).

A rügyfakadás fokozataival már több kutató is foglalkozott. Bos (1893) növényfenológiai értekezésében meghatározta a rügyfakadás definícióját, amely szerint az a nap, amelyen normál, ránctalan levelek láthatóak számos helyen, a fákon, de még nem bontakoztak ki teljesen. Hasonló definíciót alkalmaztak a németországi fenológiai megfigyelésekhez (Deutsche Wetterdienst, 1991). Az egyik legismertebb rendszer, mely a szőlő összes fenológiai fázisát részletesen leírja, az Eichorn és Lorenz által 1977-ben elkészített 47 fokozatból álló felosztás (3. táblázat). 
Az Eichorn-Lorenz-féle felosztás módosított változatát Coombe publikálta 1995-ben. Egyéb ismert rendszerek még a tőke fejlődési stádiumai (Baillod és Baggiolini, 1993), valamint a BBCH skála (Lorenz et al., 1994).

3. táblázat: A szőlőrügyek fenológiai stádiumai az Eichorn-Lorenz rendszer szerint a rügyfakadás és a virágzás folyamán (Eichorn és Lorenz, 1977)

\begin{tabular}{|c|c|}
\hline Fokozat & Fenológiai stádium \\
\hline EL 01 & Téli nyugalmi időszak alatti alvó rügy \\
\hline EL 02 & A nedvkeringés megindult, a rügyek megduzzadnak \\
\hline EL 03 & A rügypikkelyek fokozatosan szétnyílnak és közöttük megjelenik a rügygyapot. \\
\hline EL 04 & A szétnyílt rügypikkelyek között már zöldül a hajtáskezdemény. \\
\hline EL 05 & A levélrozetta megjelenik. \\
\hline EL 07 & Megjelennek az első levelek rozetta alakban. \\
\hline EL 19 & A virágzás kezdete (a pártasapkák kezdenek fellazulni és lehullani) \\
\hline EL 21 & Korai virágzási stádium (a pártasapkák 25 \%-a lehullott) \\
\hline EL 23 & Teljes virágzási stádium (a pártasapkák 50 \%-a lehullott) \\
\hline EL 25 & Kései virágzási stádium (a pártasapkák $80 \%$-a lehullott) \\
\hline
\end{tabular}

A szőlőfajták rügyfakadásának ismeretében meghatározható, hogy egyes termőhelyekre milyen fajtákat, illetve klónjaikat érdemes telepíteni. Egyes kártevők, pl. atkák (szőlőgubacsatkák, takácsatkák és levélatkák) és kórokozók, mint a szőlőlisztharmat (Uncinula necator Sch. Burr.) nagy számban telelnek át a rügyekben, és rügyfakadás után a fiatal hajtásokat károsítják. Kellö időben és a rügyfakadás ismeretében végzett, célzott növényvédelemmel az általuk okozott kár jelentősen csökkenthető. Ezért a rügyfakadás időpontjának minél pontosabb becslése növényvédelmi szempontból nézve is kívánatos. A növényvédelemhez szükséges fenológiai stádiumokat Csepregi és Zilai (1988) határozták meg a rügyfakadásra vonatkozóan, a következőképpen:

„A" állapot: a rügy nyugalmi állapota

„B” állapot: a rügyek duzzadnak és a rügygyapot éppen megjelenik

„C” állapot: a rügy megnyúlik, és a vége kizöldül

„D” állapot: az első levelek kibújnak rügyből, de még a rügygyapot összetartja őket (Csepregi és Zilai, 1988).

A szőlő virágzása Magyarországon általában május vége és június közepe között zajlik, mely az elmúlt évtizedek során tapasztalt klímaváltozás és az időjárási anomáliák miatt módosulhat. Az időjárási tényezők közül elsősorban a hőmérséklet és a levegő relatív páratartalma határozza meg a szőlő virágzásának kezdetét. Jelentős eltérések vannak továbbá a Vitis vinifera L. és az 
észak-amerikai vagy kelet-ázsiai szőlőfajok virágzási ideje, valamint a korai és későn érő fajták között (Bényei et al., 1999).

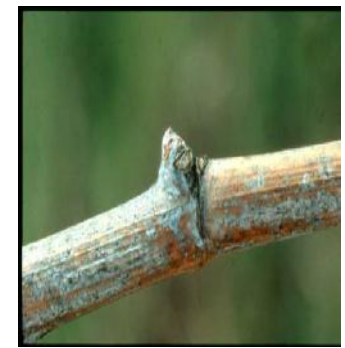

EL 01

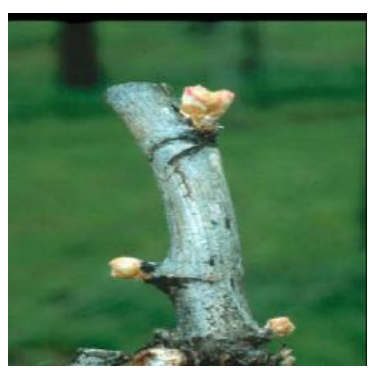

EL 04

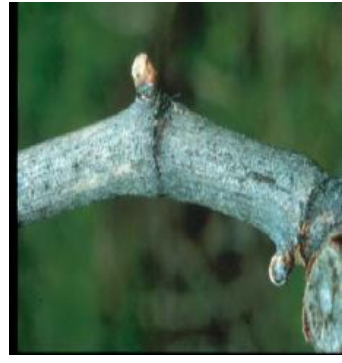

EL 02

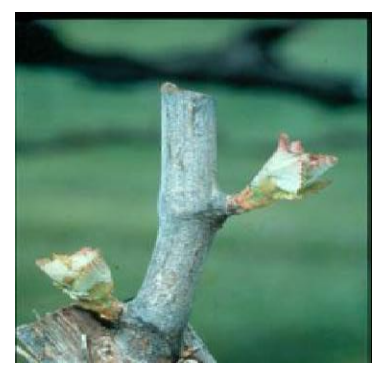

EL 05

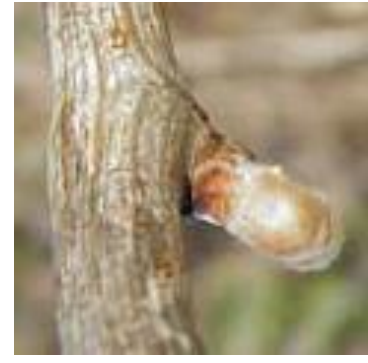

EL 03

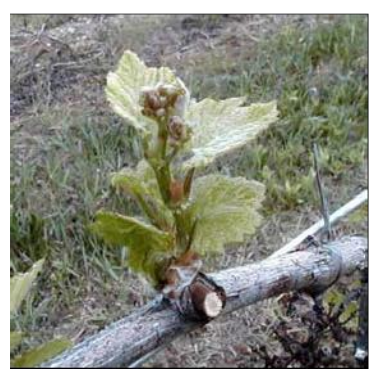

EL 07

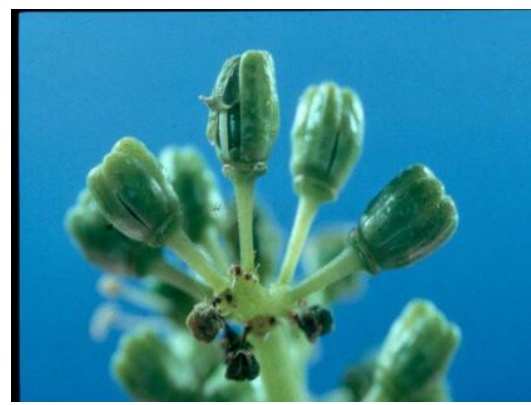

EL 19

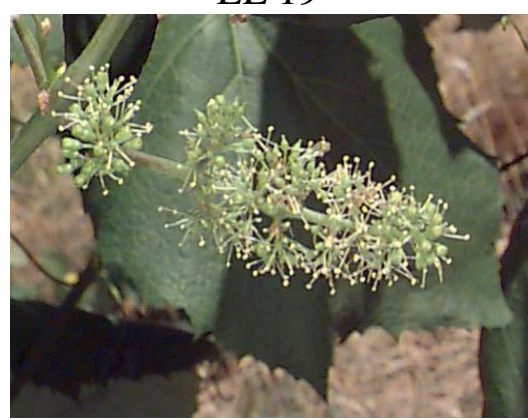

EL 23

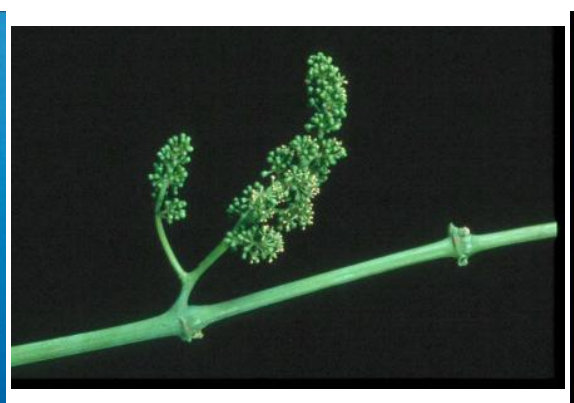

EL 21

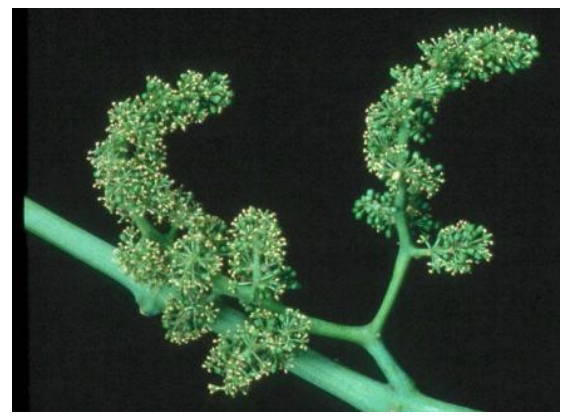

El 25

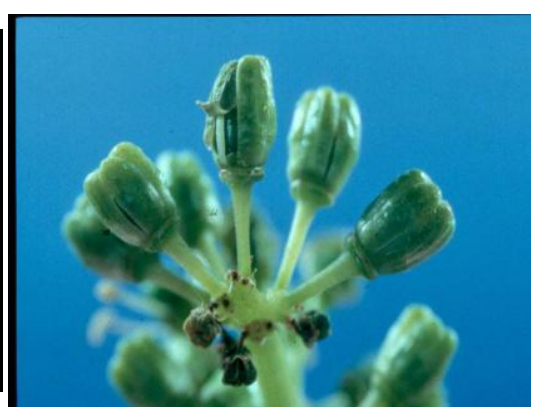

EL 19

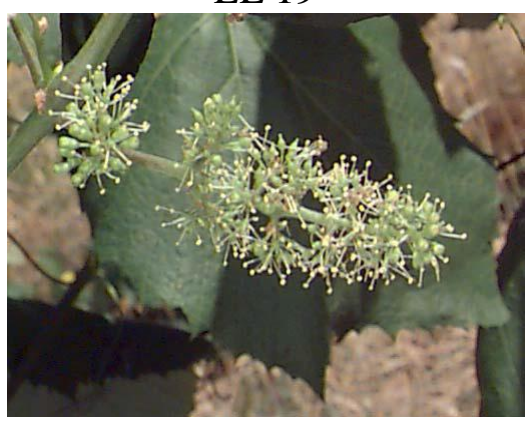

EL 23

5. ábra: A rügyfakadás és virágzás fázisai az Eichorn-Lorenz rendszer szerint (Stafne és Ker, 2009). Grapevine Phenology and Data Collection, Oklahoma State University.

Forrás:

http://www.grapes.okstate.edu/PDFs/2009/GrapevinePhenologyandDataCollection2009.pdf A szőlő virágzásához ideális hőmérséklet 20 és 26 Celsius fok között mozog, kedvezötlen viszont a nagyon alacsony páratartalom száraz időjárás esetén, illetve a túlzott mennyiségü csapadék is hátrányos. A virágnyílást akkor tekintjük megkezdettnek, amikor a virágok 4-5\%-a kinyílt. A tömeges virágzás (fővirágzás) időpontját pedig arra a napra határozták meg, amikor az adott fajtánál a virágok 60-70 \%-a kinyílt (Kozma, 1991; Bényei et al., 1999). 
Munkánk során hosszú idősorok adataira, és így a megfigyelést végző szakemberek ítéletére támaszkodtunk. A rügyfakadás időpontját arra a napra jegyezték fel, amikor a rügyek 50\%-a kipattant (EL05), a virágzást pedig arra a napra, amikor a teljes virágzás kezdetét észlelték (EL23).

\subsection{Matematikai modellek és alkalmazásuk}

A múlt század második felében a modellezés az ökológiai, genetikai és fiziológiai törvényszerüségek megismerésével egyidőben, azzal párhuzamosan igen gyorsan fejlődött. A terepi mérőmüszerek színvonalának és megbízhatóságának rohamos növekedése jó alapot adott ehhez a fejlődéshez, ámde az egyre bővülő információmennyiség egy-egy modellbe való bevonása az ötvenes-hatvanas évek egyszerü, világos modelljeit a hetvenes-nyolcvanas évekre bonyolulttá és nehézkessé duzzasztotta. A modellezés elmélete ebben a fázisában új megoldásokat követelt, amihez a számítógépek elterjedése adott lehetőséget és motivációt. Az ökológiai rendszerek elsősorban elméleti célból végzett biológiai-matematikai leírásától, a klasszikus értelemben vett modellezéstől elkezdték megkülönböztetni a gyakorlati alkalmazás céljából végzett ún. szimulációt. Korábban egy modell minél általánosabb, annál értékesebb volt, egy szimuláció azonban akkor bizonyult jobbnak, ha minél több részletre terjedt ki, azaz minél specifikusabb volt. A szimulációs modellezés első képviselői (de Wit és Keulen, 1972; de Wit és Goudriaan, 1974; Passioura, 1973; de Wit, 1982) a modellezés-tudomány fejlődését új pályára terelték. A nyolcvanas-kilencvenes évek feladata az volt, hogy a túlbonyolított, kezelhetetlen rendszereket megfelelő módon leegyszerüsítsék, és jól működő, megfelelően aprólékos, ámde áttekinthető rendszereket alkossanak (Goudriaan és Zadoks, 1995).

\subsubsection{A szimulációs modellek jellemzői}

A múlt század végi kezdeti tapasztalatok alapján nyilvánvalóvá vált, hogy nem lehet a szimulációs modelleket egyszerűen ,jo’” és „rossz” kategóriába sorolni, hanem alkalmazásuk, illetve értékelésük előtt részletesen meg kell határozni (Ladányi, 2006):

- mit kívánunk modellezni (ekkor szükségszerüen kiragadunk egy általunk önkényesen középpontba állított problémakört, jelenség(csoport)ot, és azt mutatjuk be, minden mást bemenő adatnak, kimenő adatnak tekintünk, illetve elhanyagolunk);

- a modellünket hol, milyen körülményekre szeretnénk alkalmazhatóvá tenni;

- milyen célból végezzük a modellezést (tudományos kutatás, oktatás, tanácsadás);

- fiziológiai (biológiai-oksági kapcsolatokat feltáró) vagy statisztikai (mért adatok összefüggéseit leíró modellt választunk-e;

- sztochasztikus (a véletlen eseményektől való függést is ábrázoló) vagy determinisztikus szemléletet képviselünk-e; 
- analitikus vagy empirikus modellt alkotunk-e (az előbbinél bizonyos törvényszerüségeket matematikailag írunk le, a hangsúly a modell valóságosnak megfelelő müködésén van, az utóbbi esetben a leíró függvény alakja nem illeszkedik tudományos törvényszerüségre, ámde a függvény értékei jól közelítik a megfigyelt értékeket);

- diszkrét vagy folytonos időszemléletü legyen-e a modell, diszkrét modell esetén milyen léptéket válasszunk;

- a modellt leírásra vagy elörejelzésre szeretnénk-e használni (esetleg mindkettőre);

- milyen bemenő adatokra lesz szükségünk, ezek az adatok elérhetőek-e, illetve milyen adatkorrekcióra lesz szükségünk a megfelelő inputok előállításához (le-, illetve felskálázási problémák tisztázása);

- milyen szoftver segítségével, illetve milyen nyelven írjuk a modellt;

- milyen számítógépes támogatottságot igényel a modell futtatása.

A kérdések más-más módon való megválaszolása igen eltérő szimulációs modelleket eredményez. Ennek is köszönhető, hogy az elmúlt közel 30 év alatt a világ számos területén szimulációs modellek tízezrei születtek, egyes helyeken egész iskolák alakultak ki. Európában a leghíresebbek a holland wageningeni modellező iskola, a francia INRA intézet iskolája, illetve a német geisenheimi modellező iskola. Egy jól működő modellt más területen, más feltételekkel való alkalmazása igen nagy körültekintést igényel, erre a modellek megfelelő korrigálásával számos példát ismerünk. A szük keresztmetszetet az esetek nagy részében nem is a modell struktúrája jelenti, hanem a szükséges bemenő adatok típusának különbözősége, elérhetősége, avagy teljes hiánya. A szimulációs modellezés ez okból részben a kutatók „lokális” problémához rendelt feladata lett.

\subsubsection{A modellezés föbb lépései}

- A szimulációs modellezés első lépésében a fent felsorolt kérdéseket kell tisztáznunk, azaz a céljainkat világosan meg kell határoznunk. A modell megalkotása után ez alapján végezhetjük el a modell értékelését.

- Az általunk kiemelt ökológiai-biológiai összefüggéseket matematikailag megfogalmazzuk. Ezután következhet a modell értékelése.

- Az értékelés során ellenőrizzük, hogy a modell matematikai-ökológiai-biológiai összefüggései önmagukban egymásnak megfelelnek-e (úgy „viselkedik-e” a modell, ahogy azt az ökológiai-biológiai törvények „elöírják”, nincs-e benne ellentmondás);

- Ezután az elméleti modellt futtatható alakra hozzuk valamely szoftver vagy programozási nyelv alkalmazásával, és igazoljuk a célok között meghatározott érvényességi körben, hogy a futó modell elvileg helyesen müködik. 
- A rendelkezésünkre álló tapasztalati (kísérleti, megfigyelt stb.) adatok egy részével, mint bemenő adattal futtatjuk a modellt, s az eredményt összehasonlítjuk a bemenő adatokhoz tartozó tapasztalati adatokkal (validálás). Nagyobb modellek esetén szükség lehet a komplex modell némileg önálló egységekre való felbontására, és az egyes részmodellek külön-külön való validálására.

- A validálás során valamely függvénnyel meghatározott hibát a paraméterek megfelelő módon és mértékben való változtatásával minimálisra, illetve adott türéshatáron alulira csökkentjük, azaz meghatározzuk az optimális paramétereket, vagy azok egy családját (kalibrálás); az előrejelzésre szánt modellezésnél az alacsony hibahatár különös hangsúlyt kap. (A kalibráláshoz és a validáláshoz más-más adatcsaládot használunk, pl. különböző évek adatait. A kalibráláshoz - megfelelő kontrollal - generált bemenő adatok is használhatóak (Wolf et al., 1995). A más célra, más körülményekre már futó modellek saját célra és környezetre való adaptációja is a kalibrálással kezdődik.

- A bizonytalansági tényezők detektálása: ökológiai modelleknél különösen is fontos figyelembe vennünk a bemenő (pl. időjárási, talaj minőségi) adatok bizonytalanságát. Megvizsgáljuk, hogy a bemenő adatok bizonytalansága a kimenő adatokban milyen bizonytalanságot eredményez. Ha a kimenő adatok bizonytalansága nagyon megnövekszik, akkor megkeressük ennek okát. Ha a bemenő adatok között magas a korreláció (hőmérséklet, csapadék, hőösszeg, stb.), akkor az a kimenő adatok bizonytalanságát növeli. Ilyenkor szükség lehet a bemenő adatok információjának tömörítésére (faktoranalízis).

- Érzékenységi vizsgálat: megvizsgáljuk, hogyan reagál a modell a bemenő paraméterek finom változtatására. Ezzel részben pontosabban kijelölhetjük a modell alkalmazhatósági területét, részben pedig kiszürhetjük azokat a paramétereket, amelyek változására a modell nem érzékeny. A hangsúlytalan bemenő paraméterek ugyanis torzítják az optimális paraméterértékeket. Ha az ilyen paramétereket el tudjuk hagyni a modellből, vagy (akár több ízben, különböző értékeken) rögzíthetjük azokat, akkor a validálást újra és újra el kell végezni egy feltehetően jobb eredmény reményében. A modell egyes bemenő adatokra való nagyfokú érzékenységére sok esetben elvi magyarázatot találunk.

\subsubsection{A klímamodellek}

A klímamodellek alapvető eszközök az éghajlati változások megértéséhez, melyek lehetővé teszik a lényeges légköri, óceonográfiai, krizoszférikus és földfelszíni adatok szintézisét, előrejelzéseket nyújtva a természetes és antropogén klímaváltozásról. A klímamodellek bonyolult, egymással szoros összefüggésben álló fizikai folyamatokat írnak le nagyszámú matematikai formulával, és így modellezik többek között a légkör és az óceán 
mozgását, hőmérsékletét, sürüségét, a levegő nyomását, páratartalmát, a víz körforgását, felhők és ciklonok képződését stb. A Föld felszínére egy képzeletbeli rácshálózatot illesztve a számításokat egy-egy rácspontra vonatkozóan végzik el. Attól függően, hogy milyen célra szeretnénk alkalmazni, ezek a modellek szolgálhatják a rövid- vagy hosszú távú előrejelzést, vagy akár az éghajlat 20-50 vagy 100 év múlva várható változásának leírását is. A modellek pontossága függ attól, hogy milyen egyszerüsítéseket alkalmaznak a fizikai folyamatok leírásánál, a mérőállomások milyen sürün fedik le a vizsgált területet, milyen változékonyak a domborzati viszonyok, milyen sürü rácspontokon futtatják a modelleket stb. Ha pedig a klímaváltozást leíró modellekről beszélünk, akkor nem hagyhatjuk figyelmen kívül az emberi tevékenység hatásait sem.

Az éghajlat előrejelezhetőségének és a klímaváltozás antropogén tényezőinek kutatására 1980-ban alapított Földi Éghajlatkutató Program intézménye (WCRP-World Climate Research Programme - http://www.wcrp-climate.org/) és a Meteorológiai Világszervezet (WMO - World Meteorological Organization - http://www.wmo.int/pages/) Időjáráskutató Programja (WWRP - World Weather Research Programme) - 2008-ban összehívott egy szakértői csoportot, hogy felülvizsgálják a jelenlegi modellezés állapotát és javasoljanak stratégiát egy egységes időjárási és éghajlati előrejelzésre, napjainktól az elkövetkező évszázadokra. A csoport végső következtetése az volt, hogy a jelenlegi klímamodellek generációjának kivetítése nem elégséges ahhoz, hogy pontos és megbízható előrejelzéseket adjon a regionális éghajlati változásokról, beleértve a szélsőséges események statisztikáit és az erős időjárási hatásokat, melyek szükségesek a regionális és lokális stratégiák átültetéséhez. Egy új modellezési rendszert terveztek, amely képes elöre jelezni mind a belső változékonyságot, mind a külső erőhatások változásait, valamint megjósolja a felszíni hőmérséklet-változásokat a korábbinál lényegesen nagyobb pontossággal, több dekádon keresztül, globálisan és több régióban (WMO, 2009).

A globális klímamodellek a fizikai törvényszerüségeken túl a klimatikus viszonyokat nagymértékben befolyásoló gazdasági és társadalmi folyamatok jellemzésére szolgáló ún. alapszcenáriók ('forgatókönyvek') feltételrendszerére épülnek. A kutatók négy alapszcenáriót dolgoztak ki, ezek a következők (6. ábra):

A1: globális gazdasági szcenárió - a gazdasági-társadalmi problémákra elsősorban globális és rövidtávon is gazdaságos megoldások születnek. Ez a legsúlyosabb következményekkel járó változat, de sajnos egyelőre ez a legvalószínűbb. Ezért ezt további három részre bontották (A1F1 - fosszilis intenzív, A1B - egyensúlyban van a fosszilis üzemanyagok használata és a megújúló energiaforrásokra épülő technológiák kivitelezése, A1T - nem-fosszilis energiaforrások használata); 
A2: gazdasági regionális szcenárió - a gazdasági-társadalmi problémákra elsősorban regionális és rövidtávon is gazdaságos megoldások születnek;

B1: globális környezeti - a gazdasági-társadalmi problémákra elsősorban globális és rövidtávon nem feltétlenül gazdaságos, a környezet védelmét előtérbe helyező megoldások születnek;

B2: regionális környezeti szcenárió - a gazdasági-társadalmi problémákra elsősorban regionális és rövidtávon nem feltétlenül gazdaságos, a környezet védelmét előtérbe helyező megoldások születnek. Ez a legkevésbé valószínü forgatókönyv, realitása igen kétséges (IPCC, 2007).

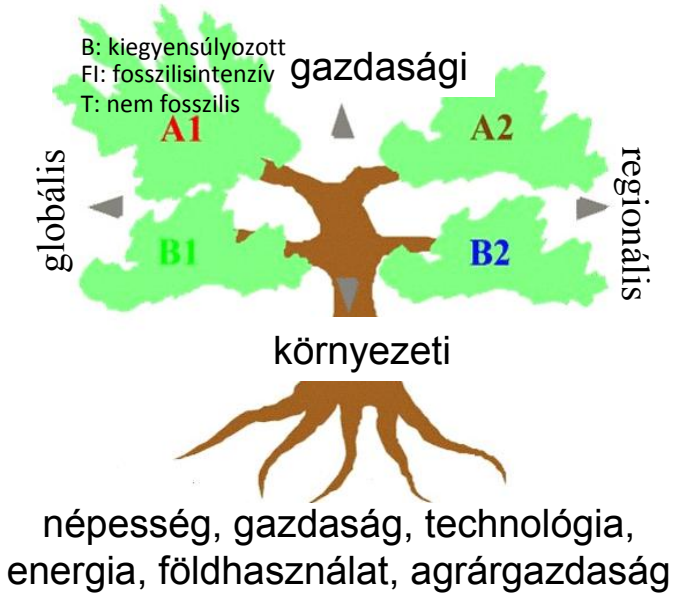

6. ábra: SRES éghajlatváltozási forgatókönyvek (forrás: IPCC, 2007)

A globális klímamodellek jellemzően 100 km (vagy annál durvább) felbontásúak. Az A1, B1 és az A2, B2 szcenáriópárok a globalizációs folyamatok felgyorsulása, illetve a régiónkénti fejlődés mentén prognosztizálják a jövőt. Az A1, A2 szcenáriók esetén a gyors gazdasági fejlődésé, míg a B1, B2 esetben a környezettudatos technológiai fejlesztéseké az elsőbbség (Harnos et al., 2008, 6. ábra). Ennek következtében a kibocsátás (s egyben a klímaváltozás mértéke) szempontjából az A1 a leginkább pesszimista és a B2 a leginkább optimista forgatókönyv. Az A1 forgatókönyv három alcsoportja (A1T, A1B, A1F1) közül a leggyakrabban az A1B emissziós szcenáriót alkalmazzák. Ez egy olyan jövőt prognosztizál, amelyben a népességszám 2050-ig gyors ütemben növekszik, eléri a körülbelül 9 milliárdos értéket, majd csökkenni kezd. Az évek során új, hatékony technológiák kerülnek bevezetésre, és a különféle társadalmak között egyre több kulturális egymásra hatás érvényesül, ennek következtében csökkennek a különböző földrajzi régiók közötti eltérések. Továbbá feltételezi a fosszilis és nem fosszilis energiaforrásokra támaszkodó energiatermelő rendszerek technológiai fejlődését. Az A1B forgatókönyv tehát egy mérsékelten optimista és egy mérsékelten pesszimista jövőkép ötvözeteként jött létre (IPCC, 2001, Harnos et al., 2008). 


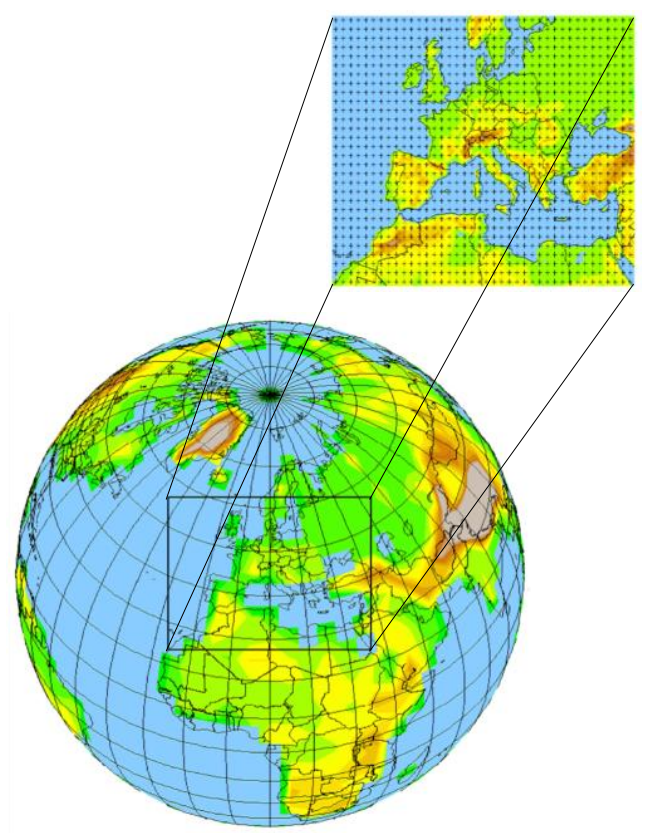

7. ábra: A globális klímamodellek regionális leskálázása (forrás: WMO)

Finomabb térbeli eredmények elérésének érdekében nagyobb felbontású, ún. regionális modellek is használatosak. A regionális modellekhez globális modellek szolgáltatják a futáshoz szükséges kezdeti- és peremfeltételeket. A regionális modell a durvább felbontású globális klímamodellbe beágyazva, egy kisebb régióra, finomabb felbontás mellett végzi el a számításokat, ezáltal regionális szintű információkat szolgáltat a felhasználónak (7. ábra). A RegCM3.1-gyel a beágyazásos módszert alkalmazták a regionális A1B éghajlati jövőkép elkészítéséhez az ELTE Meteorológiai Tanszékén (Bartholy et al., 2007, 2009 és 2010), ahol 2005 óta folynak RegCM-en alapuló kutatások. A módosított RegCM3.1 (Torma et al., 2011) modell futtatásához az ECHAM5 (Roeckner et al., 2003) globális éghajlati modell biztosította a kezdeti- és peremfeltételeket. Az adatbázisban elérhető adatok horizontális felbontása $10 \mathrm{~km}$.

Bár a rácspontok sűrítésével előállított regionális klímamodellek bizonytalansága az idők során nagymértékben csökkent, sajnos még mindig elég magas maradt. Ez mégsem elég ok arra, hogy ne használjuk fel a jövőbeli éghajlatunkról ily módon nyert információt.

\subsubsection{A fenológiai modellek}

Az 1970-es évek óta felismerték, hogy a fenológia kiemelkedő szerepet játszik az ökoszisztémák produktivitásának modellezésében (Lieth, 1971). A szakirodalomban fóleg az erdészeti kutatásokban találkozhatunk fenológiai modellekkel, gyümölcsfákra az ilyen jellegü kutatások még gyerekcipőben járnak. A fák rügyfakadásának idejét előrejelző modelleket az erdészetben már csaknem két évtizede széles körben alkalmazzák, hogy feltárják a globális felmelegedésnek a fák fenológiájára vonatkozó hatását (Hänninen et al., 1993; Kramer, 1994b; Hänninen, 1995; Kramer, 1995; Hänninen et al., 1996; Hänninen, 1996). Fenológiai modelleket alkalmaznak a fásszárúak szárazföldi szénkörforgalomban betöltött szerepének leírására is 
(Lieth, 1971; Kramer et al., 1996; Kramer és Mohren, 1996). A fenológiai modellekben a hőmérséklet elismerten a legfontosabb szabályozó változó, mely meghatározza a rügyfakadás, valamint a virágzás időzítését.

A fenológiai modellekre szükség van az ökoszisztémák környezeti szolgáltatásának becsléséhez, előrejelzéséhez és a szükséges helyreállítást célzó stratégiák kidolgozásához is (Lieth, 1971; Kramer és Mohren, 1996; Kramer et al., 1996). Fenológiai modellek segítségével becsülhető a fagykár-kockázat a melegedő éghajlaton (Cannell és Smith, 1986; Murray et al., 1989, 1994; Prentice et al., 1991; Hänninen et al., 1993; Kramer, 1994 a, 1995; Hänninen, 1996), valamint alkalmazásukkal pontos döntéstámogató eszközök fejleszthetök ki a növénytermesztök és az újraerdősítési programok számára.

A fenológiai modellek másik fontos alkalmazási területe a fajok elterjedésének térbeliidőbeli előrejelzése az éghajlatváltozás fényében (Chuine és Beaubien, 2001). A növényeknek a környezeti feltételekhez történő alkalmazkodása erősen függ a fejlődés ütemezésétől az éghajlat szezonális változásai során. Ezért az éghajlat egyik fő, az adaptív kapacitást nagymértékben befolyásoló vonása, hogy a fenológián keresztül meghatározza a populáció éves szaporodási sikerét, ezáltal a fajok alkalmazkodóképességét és az előfordulás valószínüségét bizonyos éghajlati feltételek között (Morin és Chuine, 2005).

A 21. századra történő fajspecifikus elörejelzések néhány alapvető és alkalmazott tudományos kérdés tekintetében sarkalatos tényezőkké váltak. Az egyre megbízhatóbb fenológiai elörejelzések mind jobban növelik az ökoszisztéma-szolgáltatás és a légköri gázcsere prognózisok pontosságát, ezáltal a jövőbeli éghajlatra való visszacsatolt hatásuk predikcióit; segítségükkel jobban megértjük a populációdinamikai törvényszerüségeket többfajú interakciós rendszerekben (különösen növények és állatok között); segítenek a termesztőknek kiválasztani azokat a fajtákat, amelyek fokozottabban alkalmazkodóképesek az új éghajlati feltételekhez (Cleland et al., 2007).

A fenofázisok kezdőpontjának elörejelzésére alkalmazható fenológiai modelleknek három fö típusát különböztetjük meg: elméleti modellek, statisztikai modellek és folyamat-alapú modellek (Chuine et al., 2003).

- Az elméleti modellek a leveleknek a gazdaságtudományokban kifejlesztett költség-haszon modellekkel kifejezhető produkciós folyamatain alapulnak, mégpedig úgy, hogy a fák leveleinek fejlődését szimulálják, optimalizálva a biomassza-nyereséget.

- A statisztikai modellek összekapcsolják a fenológiai események és a klimatikus tényezők tapasztalati megfigyeléseit számos matematikai függvény segítségével (Schwartz, 2003; Sparks és Tryjanowski, 2005). 
- A folyamatalapú modellek formailag írnak le ismert vagy feltételezett ok-okozati kapcsolatokat biológiai folyamatok és néhány meghatározó környezeti faktor között.

Folyamatalapú és statisztikai fenológiai modelleket használtak a múlt éghajlati változásainak rekonstruálásához történelmi fenológiai idősorokat felhasználva, például az 1370 óta Franciaországban feljegyzett, világviszonylatban is páratlan értékü szőlő szüreti adatokra is (Chuine et al., 2004).

\section{Höösszegen alapuló fenológiai modellek}

A rügyfakadás időpontjára vonatkozó fenológiai modellek azon az általánosan elfogadott feltevésen alapulnak, hogy a szőlő rügyfakadását a nyugalomban ért hideghatást követően elsősorban a növényt ért hatásos hőmennyiség határozza meg (Carbonneau et al., 1992, Jones, 2003, Jones et al., 2005). A szakirodalomban számos szerző foglalkozik fenológiai modellezéssel különböző fajtákra és termesztési feltételekre. Szinte minden modellben közös, hogy egy adott időponttól kezdődően egy adott bázishőmérséklet (sok esetben $10^{\circ} \mathrm{C}$ ) feletti höösszegeket akkumulálnak egy kritikus érték eléréséig (Moncur et al., 1989). A léghőmérsékletből kiinduló modellek közül ismerünk lineáris és logaritmikus akkumulálódást feltételezőket is (Oliveira 1998, Riou, 1994). Nem mindegy az sem, hogy a léghőmérsékletet napi léptékkel összegezzük vagy óránkéntivel (Cortázar-Atauri et al., 2005). Ez utóbbihoz a vizsgált időszak minden napjára ismerni vagy becsülni kell a napfelkelte, illetve naplemente időpontját is. Ez után dönthetünk arról, hogy háromszög-típusú, exponenciális vagy sinusos közelítést alkalmazunk-e. Sok esetben azonban ezek a modellek a túlzott finomítást követően korántsem teljesítik az elvárt pontosságot a nagyszámú szükséges paraméterbecslés miatt (Cortázar-Atauri et al., 2009). Fontos szempont az is, hogy az akkumulálást mely időponttól kezdjük. A szakirodalomban a legelterjedtebb ezt január elsejére választani (Riou, 1994; Bindi et al., 1997a, b).

Az első hőösszegszámításokon alapuló, fenológiai terminushoz kötött osztályozást Amerine és Winkler fejlesztette ki a Kaliforniai Egyetemen 1944-ben (2.6.1. fejezet, 7. táblázat). A Winkler-skála hőösszegzési módszerként ismert, a szőlőtermesztő régiók éghajlatának osztályozására használatos (Amerine és Winkler, 1944). Eszerint ha a régiókat a tenyészidőszak alatt (április 1-től október 31-ig) naponta, ${ }^{\circ} \mathrm{C}$-ban mért, a $10^{\circ} \mathrm{C}$ bázishőmérsékletet meghaladó hőösszegek (growing degree days) alapján definiáljuk, eredményül öt régiót kapunk, amelyek a hidegtől a meleg éghajlatig terjedő, szőlőtermesztésre alkalmas területeket és a legjobb eredménnyel termeszthető szőlőfajtákat tartalmazzák (Jones, 2007).

Az 1950-es években már Baggiolini (1952) is foglalkozott hőösszegszámításon alapuló modellel, de az igazi áttörés csak a 90-es évek vége felé történt. Ezt intenzív tudományos és 
szimulációs munka követte a növények éghajlati hatásokra adott fenológiai válaszainak vizsgálatával (Hänninen, 1990, 1991, 1995, 1996; Hänninen et al., 1993).

Az ún. Growing Degree Day $(G D D)$ modell a klasszikus höösszeg-elgondoláson alapul (Bonhomme, 2000; Salonius, 2002), azaz az akkumulált napi átlaghőmérsékletet számolják ( $\left.T_{\text {átlag }}\right)$ a bázishőmérséklet $\left(T_{b a ́ z i s}\right)$ felett, január elsejétől kiindulva. A rügyfakadás akkor történik meg, amikor a modell elér egy kritikus értéket.

Riou (1994) modellje gyakorlatilag Pouget (1968; 1988) modelljének javított változata. Itt a napi léptékü hőösszegszámítás helyett óránkénti összegzést alkalmaznak, amit a napi minimum- és maximum-hőmérsékletekből számítanak, feltételezve egy színuszos hőmérsékleti választ nappalra és egy parabolikus választ az éjszakai időszakra. A nappalhosszúságot Sellers (1965) asztronómiai formulájával számítják ki. A rügyfakadás akkor történik meg, amikor az óránként összegezett hőmennyiségek elérik a kritikus értéket.

A folyamatalapú modellek már a kényszernyugalmi időszak során is leírják a növényben lezajló folyamatokat, és összekapcsolják azokat a később, a mélynyugalmi állapot megtörését követően, a külső faktorok (általában a hőmérséklet) hatására történő fejlődési- sejtnövekedési folyamatokkal. Chuine és Cour (1999) eredményei ugyanis azt mutatják, hogy a mélynyugalom során akkumulálódott hideg hőösszegek gyorsítják az életfolyamatok beindulását, ha egyszer a mélynyugalmi állapot megtört. Más szóval általában a mélynyugalom alatt nagyobb mennyiségű hidegösszeg akkumulálódását követően a kényszernyugalomban kevesebb hőösszeg is elegendő a rügyfakadáshoz. Ezt igazolják a különböző kísérleti eredmények, melyeket különböző fafajokról kaptak (Nienstaedt, 1966; Farmer, 1968; Nelson és Lavender, 1979; Mauget, 1983; Heide, 1993; Hänninen és Backmann, 1994; Myking és Heide, 1995). Ez az egyik oka annak, hogy a hideghatást is figyelembe vevő hőösszegmodellek általában olyan területeken alkalmazhatók nagy sikerrel, ahol minden évben számíthatunk megfelelö hideghatásra, és ez a hideghatás nem túlságosan nagy, illetve nem túlságosan elhúzódó. Tipikusan ilyen például a Kárpát-medence vidéke.

Az ún. Brin-modellt két, gyümölcsfákhoz használt modell kombinációjából származtatják (Liennard, 2002; Cortázar-Atauri et al., 2005): a mélynyugalmi periódust Bidabe (1965 a, b) hideghatás-modellje (Cold Action model), a kényszernyugalmi periódust pedig Richardson és munkatársai (1974, 1975) módszerével elöállított óránkénti hőösszegzéssel (growing degree hours - GDH) számolták ki. A rügyfakadás ideje akkor következik be, amikor az óránkénti hőösszegzés a kritikus összeget eléri, amit a mélynyugalom megszünésétől számítanak. A mélynyugalom megszűnése akkor történik meg, amikor a hideg hőösszegegységek elérnek egy kritikus összeget. A hideg hőösszegek akkumulációja augusztus vagy szeptember elsejével indul, ami számos tanulmányon alapul (Alleweldt, 1963; Nigond, 1967; Champagnol, 1984; Pouget, 
1963, 1988), melyek azt bizonyítják, hogy a rügyek augusztus elsejét követően kerülnek mélynyugalomba, müvelésmódtól függetlenül. Tegyük hozzá, hogy a meleg, illetve forró nyári periódusnak az akkumulációra nincs befolyásoló hatása az északi féltekén (Cortázar-Atauri, 2009), ezért terjedt el a szeptember elsejétől való akkumulációs eljárás is, ami így lényegében azonos az augusztus elsején indulóval.

Néhány modell csak a kényszernyugalmi időszak höösszegeit veszi figyelembe, mint például a Thermal Time modell (Cannell és Smith, 1983), de nevezik Spring Warming modellnek is (Hunter és Leichowitz, 1992). A mélynyugalom és a kényszernyugalom hőösszegeit is figyelembe veszi a Parallel modell (Landsberg, 1974; Hänninen, 1990; Kramer, 1994b), a Sequential modell Sarvas, 1974; Hänninen, 1990; Kramer, 1994 b), és az Alternating modell (Murrey et al., 1989).

Az újabb, folyamatalapú modellek főleg a kényszernyugalom és a mélynyugalom fázisa folyamán a hőmérsékletre adott válasz típusában különböznek (Chuine et al., 2003).

Chuine és munkatársai (1999) rügyfakadási modelleket teszteltek abból a célból, hogy kiválasszák azokat, amelyek a megfigyeléseket a legjobban alátámasztják, valamint, hogy meghatározzanak új, előrejelzésre alkalmazható modelleket. A fenológiai modellezéshez négy alapvetően szükséges lépést fogalmaztak meg: (1) a modell meghatározása, (2) az adatgyüjtés, (3) a modell beállítása az adatokhoz és (4) a modell hipotézisének tesztelése.

\section{Adattípus szerinti fenológiai modelltípusok}

A szakirodalom feldolgozása során a modellezéshez használt fenológiai adatok típusa szerint négy csoportot különítettünk el:

1. Megfigyelés a természetben vagy ültetett populációkban (Cannell és Smith, 1983; Nizinski és Saugier, 1988; Hunter és Lechowicz, 1992; Kramer, 1994 a, b; Häkkinen et al., 1995);

2. Klónok megfigyelése különböző környezetben - fenológiai kertek (Schnelle és Volkert, 1974; Kramer, 1995);

3. Üvegház kísérletek (Perry és Wang, 1960; Nelson és Lavander, 1979; Maugét, 1983; Murray et al., 1989; Hänninen et al., 1993; Heide, 1993; Cecih et al., 1994; Hänninen, 1996; Myking és Heide, 1995);

4. Pollen emisszió mérése a légkörben, ami jelzi a populációk virágzásának idejét (Boyer, 1973; Richard, 1985; Andersen, 1991; Frenguelli et al., 1992; Chuine et al., 1998).

\section{Fenológiai modellek a klímaváltozás hatásának kutatásában}

A fenológiai modelleknek a klímaváltozás hatásainak kutatásában való alkalmazásai az 1980-as években láttak először napvilágot. 
Chuine és munkatársai (1999) nyolc modell, különböző fajokra végzett összehasonlító vizsgálata után arra a következtetésre jutottak, hogy nincs olyan egyszerü modell, mely minden faj rügyfakadását és virágzását pontosan előrejelzi. Ez azt jelenti, hogy minden lehetséges modellt tesztelni kell minden fajra. A különböző fafajok különbözőképpen válaszolhatnak az éghajlati melegedésre, és így változtatják a versenyképességüket (Kramer, 1994 a b). Mindazonáltal a legjobb lehetséges előrejelző modell jellemzői a következők:

(1) a kritikus kényszernyugalmi höösszeg és a mélynyugalmi hőösszeg egymással negatív exponenciális kapcsolatban van,

(2) a rügyfejlődésre gyakorolt hőmérsékleti hatás szimulálásához a kényszernyugalmi és mélynyugalmi hőösszeg-függvények használata alkalmasabb (Hänninen, 1990) az egyszerü hőösszeg és hidegösszeg számítások helyett és végül

(3) a kényszernyugalmi hőösszeg a kényszernyugalom kezdetétől hatékony és nem a mélynyugalom kezdetétől.

Az utóbbi évtizedben a klímaváltozás hatásainak kutatása céljából napvilágot látott különböző fenológiai modellek térbeli és időbeli összehasonlító vizsgálatait Cortázar-Atauri és munkatársai (2009) végezték el.

\subsection{A klímaváltozásnak a szőlőtermesztésre gyakorolt hatásai}

\subsubsection{Klimatikus indikátorok}

A szőlőtermesztésben a termőhelyek jellemzésére és a szőlő igényeinek kifejezésére többféle klimatikus indikátort, illetve ezek kombinációját alkalmazzák. Ezeket az indikátorokat előszeretettel használják az évtizedes adatsorokkal rendelkező vizsgálatoknál egyrészt az éghajlat változásának meghatározásához, bizonyításához, másrészt az egyes terroárok jellemzésére is.

Az indikátoranalízis során az egyes időjárási paraméterek függvényeiként olyan mesterséges időjárási paramétereket definiálunk, melyek közvetlenül kapcsolhatók a növényi válaszadás karakteréhez. Az indikátorok értékeinek részletes időbeni és térbeli eloszlásának elemzésével az indikátorok által magyarázott növényi válaszadás lényegesen pontosabban írható le. A klimatikus indikátorok analízise ezen felül a klímaváltozás hatásvizsgálatának módszertanában is jelentős szerepet tölt be. Ha ugyanis megfelelő, a klímaváltozás által leginkább érintett (specifikus) indikátorokból álló halmazt állítunk elő, akkor ezek további megfigyelésével az éghajlatváltozásnak az adott területen fellépő tünetei nyomon követhetőek. Ha pedig a jövőre vonatkozó klímamodellek regionális leskálázásából nyert adatokból is előállítjuk ezeket az indikátorokat, akkor nélkülözhetetlen információhoz jutunk a jövőben várható változásokról (Carter et al., 2007). Az ilyen jellegü információkból a jövőbeni termeszthetőségi feltételekre, illetve a kockázati tényezőkre következtethetünk. 
$\mathrm{Az}$ indikátoranalízis egyik legfontosabb feltétele, hogy viszonylag hosszú idősorok álljanak rendelkezésre. Az elemzés sikerét döntően befolyásolja az adatok minősége is. Számos szerző alkalmazza ezt a módszert a szakterületének megfelelő specifikus indikátorok bevezetésével (Bootsma et al., 2005 a, b). Indikátorok szántóföldi, erdészeti és gyümölcs növényekre éppúgy használhatók, mint rovarokra vagy gerinces állatokra (Erdélyi, 2009, Erdélyi et al., 2008, 2009, Koocheki et al., 2006, Salinger et al., 2005, Diós et al., 2009).

Mivel a szőlőfajták az optimális minőségi-mennyiségi elvárásoknak megfelelően jobbára egy viszonylag szűk területen, jellemző éghajlati körülmények között termeszthetők, a klimatikus indikátorok változásai a termés minőségi-mennyiségi, illetve a terméssel kapcsolatos gazdasági kockázat alapját képezik. Jóllehet, sok még a bizonytalanság a jövő éghajlatváltozásában, szükséges becsülnünk az éghajlat hatásait néhány széles körben elfogadott éghajlati indikátorral. A továbbiakban a teljesség igénye nélkül bemutatom a szakirodalomban fellelhető klimatikus indikátorok közül a legfontosabbnak ítélt

- 13 hőmérsékleti indikátort (Huglin-index, Winkler-index, biológiailag hatásos hőösszeg, átlaghőmérséklet januárban, júliusban, a tenyészidőszakban, illetve az érésidő alatt, átlagos maximum- és minimumhőmérséklet a tenyészidőszakban, átlagos maximumhőmérséklet a szüretidő alatt, téli minimumhőmérséklet, hüvös éjszaka index, kontinentalitás $\left[{ }^{\circ} \mathrm{C}\right]$ );

- 16 extremális indikátort (extrém meleg, meleg, nyári napok száma, fagyos, jeges napok száma télen, szőlő fagyindex és súlyos fagyindex, tavaszi, őszi fagyos napok száma, Gladstones-féle fagyindex, Wolf-Boyer-féle fagyindex, napi hőmérsékletingadozás júliusban, áprilisban, a szüretidő alatt, Zorer-féle hőingás, valamint Riberau-Gayon-Peynaud Index), továbbá

- 7 csapadékindikátort (éves, nyári, téli, a tenyészidőszakra, a virágzásra, illetve az érésidőre vonatkozó csapadékmennyiség [mm], a tenyészidőszak csapadékos napjainak száma [nap]).

A szakirodalmi gyüjtés-feldolgozás után az 4. táblázatban a hőmérsékleti, a 9. táblázatban az extremális, a 10. táblázatban pedig a csapadékkal kapcsolatos indikátorokat foglaltam össze. A hivatkozásokat a táblázatban az indexek neve mellett adom meg, továbbá feltüntetem az angol nyelvben használatos elnevezésüket, rövidítésüket, valamint a mértékegységüket. Meghatározom az indikátorok általunk használt számításának módját is.

A számítási mód megadásának azért is van jelentősége, mert ugyanazon a néven elterjedt klimatikus indikátorok számítási módja egyes esetekben különbözhet abban az értelemben, hogy azt napi vagy havi adatokból számítják. Munkám során minden esetben a pontosabb, napi adatokból számolt indikátorokat állítottam elő, azaz a képletekben szereplő $T_{\min }, T_{\max }, T_{\text {atlag }}$ értékek napi minimum-, maximum- és átlaghőmérsékleteket jelentenek. 
Magyarországi viszonyok között a szölészeti szakemberek által leggyakrabban alkalmazott jelzőszámok a tenyészidőszak hatásos hőösszege és az Huglin-féle heliotermikus index. A tenyészidőszak hatásos hőösszegének meghatározásához tudni szükséges a tenyészidőszak hosszát napokban mérve. Erre többféle módszer ismert, melyekre részletesebben a 3.6 fejezeben térek ki. A szőlőfajták hőösszegigényük alapján csoportosíthatóak (5. táblázat).

Hömérsékleti indikátorok

4. táblázat: A szőlőtermesztésben alkalmazott hőmérsékleti indikátorok

\begin{tabular}{|c|c|}
\hline $\begin{array}{l}\text { Hőmérsékleti indikátorok, jelölések, } \\
\text { mértékegységek, hivatkozások }\end{array}$ & Meghatározása \\
\hline $\begin{array}{l}\text { Heliotermikus- vagy Huglin-index }(H I \text {, } \\
{\left[{ }^{\circ} \mathrm{C}\right] \text {, Huglin, 1978, 1986) }}\end{array}$ & $\begin{array}{c}H I=\sum_{\text {Apr.1. }}^{\text {Szept.30. }} \frac{\left[\max \left(0 ;\left(T_{\max }-10\right)\right)+\max \left(0 ;\left(T_{\text {átlag }}-10\right)\right)\right]}{2} * K \\
\mathrm{~K}=1,05 \text { Magyarország szélességi fokán }\end{array}$ \\
\hline $\begin{array}{l}\text { Winkler-index }\left(W I,\left[{ }^{\circ} \mathrm{C}\right]\right)(\text { Amerine és } \\
\text { Winkler, 1944, Winkler et al, 1974, } \\
\text { Riou, 1994) }\end{array}$ & $W I=\sum_{\text {Apr.1. }}^{\text {Okt.31. } \max }\left[\left(T_{\text {atlag }}-10\right) ; 0\right]$ \\
\hline $\begin{array}{l}\text { Biológiailag hatásos höösszeg } \\
\text { (Biologically Effective Day Degrees - } \\
\text { BEDD, }\left[{ }^{\circ} \mathrm{C}\right] \text {, Gladstones, 1992, 2000) }\end{array}$ & 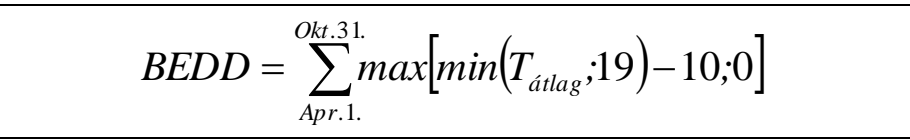 \\
\hline $\begin{array}{l}\text { Júliusi átlaghőmérséklet (Mean July } \\
\text { Temperature - MJuT, }\left[{ }^{\circ} \mathrm{C}\right] \text {, Dry és } \\
\text { Smart, 1988) }\end{array}$ & $M J u T=\underset{\text { Jútlus } 1-31 .}{\text { Átlag }}\left(T_{\text {átlag }}\right)$ \\
\hline $\begin{array}{l}\text { Januári átlaghömérséklet }(\text { Mean } \\
\left.\text { January Temperature - MJaT, }\left[{ }^{\circ} \mathrm{C}\right]\right)\end{array}$ & $M J a T=\underset{\text { Januán-31. }}{\operatorname{Aattag}})$ \\
\hline $\begin{array}{l}\text { Tenyészidőszak átlaghőmérséklete } \\
\text { (Growing Season Average Temperature } \\
- \text { GSAT, }\left[{ }^{\circ} \mathrm{C}\right], \text { Jones és Goodrich, 2008) } \\
\end{array}$ & $G S A T=\underset{\text { Apr.1-Okt.31. }}{\text { Atlag }}\left(T_{\text {atlag }}\right)$ \\
\hline $\begin{array}{l}\text { Tenyészidőszak átlagos maximum- } \\
\text { hömérséklete (Growing Season Average } \\
\text { Maximum Temperature - GSATX, }\left[{ }^{\circ} \mathrm{C}\right] \text {, } \\
\text { Jones és Goodrich, 2008) }\end{array}$ & $G S A T X=\underset{\text { Apr.1-Okt.31. }}{\text { Átlag }}\left(T_{\max }\right)$ \\
\hline $\begin{array}{l}\text { Tenyészidőszak átlagos minimum- } \\
\text { hőmérséklete (Growing Season Average } \\
\text { Minimum Temperature - GSATN, }\left[{ }^{\circ} \mathrm{C}\right] \text {, } \\
\text { Jones és Goodrich, 2008) }\end{array}$ & $G S A T N=\underset{\text { Apr.1-Okt.31. }}{\text { Atlag }}\left(T_{\min }\right)$ \\
\hline $\begin{array}{l}\text { Szüretidei átlagos } \\
\text { maximumhömérséklet (Harvest } \\
\text { Maximum Temperature - HMX, }\left[{ }^{\circ} \mathrm{C}\right] \text {, } \\
\text { Webb et al., 2005, Happ, 1999) }\end{array}$ & $H M X=\underset{\text { Jún.1.-Szept. } 30 .}{\text { Atlag }}\left(T_{\max }\right)$ \\
\hline $\begin{array}{l}\text { Téli minimumhőmérséklet }(\text { Winter } \\
\text { Minimum Temperature - WMN, }\left[{ }^{\circ} \mathrm{C}\right] \text {, } \\
\text { Webb et al., 2005, Happ, } 1999 \text {, Suthurst } \\
\text { et al., 2000) }\end{array}$ & $W M N=\underset{\text { Dec.1-Feb.28. }}{\operatorname{Min}}\left(T_{\min }\right)$ \\
\hline $\begin{array}{l}\text { Érésidei átlaghőmérséklet (Ripening } \\
\text { Average Temperature - } R A T,\left[{ }^{\circ} \mathrm{C}\right] \\
\text { Jones és Goodrich, 2008) }\end{array}$ & $R A T=\underset{\text { Aug.15-Okt.15. }}{\text { Atlag }}\left(T_{\text {átlag }}\right)$ \\
\hline $\begin{array}{l}\text { Hideg éjszaka index (Cool Night Index- } \\
\text { CNI, }\left[{ }^{\circ} \mathrm{C}\right] \text {, Tonietto és Carbonneau, } \\
2004)\end{array}$ & $C N I=\underset{\text { Szept. } 1-30 .}{\operatorname{Atlag}}\left(T_{\min }\right)$ \\
\hline $\begin{array}{l}\text { Kontinentalitás (Continentality - } \mathrm{CO}, \\
{\left[{ }^{\circ} \mathrm{C}\right] \text {, Gladstones, 1992) }}\end{array}$ & $C O=M J u T-M J a n T$ \\
\hline
\end{tabular}


5. táblázat: Szőlőfajták csoportosítása a hatásos hőösszegigényük alapján a teljes érésig (Botos és Hajdu, 2004)

\begin{tabular}{|c|c|}
\hline Hatásos höösszeg & Érési kategóriák \\
\hline $690-850^{\circ} \mathrm{C}$ & Nagyon korai érésü fajták \\
\hline $850-1150^{\circ} \mathrm{C}$ & Korai érésü fajták \\
\hline $1150-1350^{\circ} \mathrm{C}$ & Közepes érésü fajták \\
\hline $1350-1600^{\circ} \mathrm{C}$ & Kései érésü fajták \\
\hline $1600^{\circ} \mathrm{C}$ felett & Nagyon kései érésü fajták \\
\hline
\end{tabular}

Az Huglin-index $(H I)$ a 40-50 szélességi körök között változó fotoperiódust, valamint a napi középhőmérsékletek és a napi maximális hőmérsékletek együttes hatását is figyelembe veszi (Kozma, 1991). Az Huglin-index értékek szerint termőhelytípusok osztályait definiálhatjuk (6. táblázat).

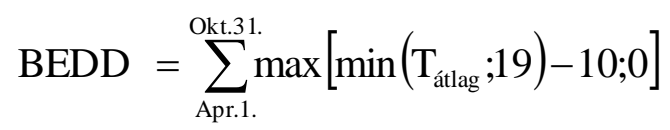

6. táblázat: Az Huglin-index értékek szerint csoportosított termőhelytípusok (Tonietto és Carbonneau, 2004)

\begin{tabular}{|c|c|}
\hline Huglin-index $\left[{ }^{\circ} \mathrm{C}\right]$ & Osztály neve \\
\hline $\mathrm{HI} \leq 1500$ & Nagyon hideg \\
\hline $1500<\mathrm{HI} \leq 1800$ & Hideg \\
\hline $1800<\mathrm{HI} \leq 2100$ & Mérséklet \\
\hline $2100<\mathrm{HI} \leq 2400$ & Meleg mérséklet \\
\hline $2400<\mathrm{HI} \leq 3000$ & Melegtől a nagyon melegig \\
\hline $3000<\mathrm{HI}$ & Forró \\
\hline
\end{tabular}

A Winkler-index $(W I)$ szerint a szőlőtermesztő régiókat is osztályozhatjuk. Winkler és munkatársai (1974) a földrajzi területeket öt éghajlati régióra osztották (7. táblázat).

7. táblázat: A Winkler-index értékek szerint csoportosított termőhelytípusok (Amerine és Winkler, 1944, Winkler et al., 1974)

\begin{tabular}{|c|c|}
\hline Winkler-index $\left[{ }^{\circ} \mathrm{C}\right]$ & Régiók \\
\hline $\mathrm{HI} \leq 1390$ & I. Hüvös \\
\hline $1391<\mathrm{HI} \leq 1670$ & II. Mérsékelt \\
\hline $1671<\mathrm{HI} \leq 1940$ & III. Meleg mérsékelt \\
\hline $1941<\mathrm{HI} \leq 2220$ & IV. Meleg \\
\hline $2220<\mathrm{HI}$ & V. Forró \\
\hline
\end{tabular}

A biológiailag hatásos hőösszeg $(B E D D)$ az egyszerü, bázishőmérséklet feletti hőértékeket akkumuláló hőösszegtől annyiban külünbözik, hogy figyelembe vesz egy ún. felső bázishőmérsékletet is, egy olyan küszöbértéket, mely felett a növény már feltehetőleg nem képes a teljes hőösszeget hasznosítani (Gladstones, 2000).

A júliusi középhőmérséklet $(M J u T)$ hatásal lehet a bogyó cukor- és savtartalmának változására. A fajták érési sorrendjétől függően július hónapban befejeződik a zsendülés utolsó ciklusa, és megkezdődik az érés, azaz a cukorfelhalmozódás időszaka. Az érést a hüvös, csapadékos időjárás hátráltatja, a beérés minőségét csökkenti; míg a napos, meleg időjárás sietteti a folyamatot, a beérés minőségét pedig fokozza (Kozma, 1991). 
A januári középhőmérséklet $(M J a T)$ a kényszernyugalmi időszak kezdetéről ad információt. Ismeretes ugyanis, hogy a rügyek csak a kedvezőtlen, hideg, fagyos időjárás miatt maradnak nyugalomban (Kozma, 1991).

A tenyészidőszak átlagos (GSAT), maximum- (GSATX) és minimumhőmérséklete (GSATN) a növény reproduktív életciklusában meghatározza a fenológiai fázisok dinamikáját.

A szüretet megelőző időszakban, június 1-től szeptember 30-ig mérik az ún. szüretidei maximumhőmérsékletek átlagát $(H M X)$, mely a felmelegedéssel különös jelentőségü lehet, hiszen a növényt ért hőstresszről ad információt.

A téli minimumhömérséklet-indikátor $(W M N)$ december és február között a tél hőviszonyairól ad információt, ami a szőlő növekedésére, fejlődésére, a rügyfakadás időpontjára is hatással van, valamint a téli fagykockázat számításának egyik alapja.

Az érésidei középhőmérséklet-indikátor $(R A T)$ az augusztus 15-e és október 15-e közötti átlaghőmérsékleteket összegzi. Az érési időszak alatt a levegő hőmérséklete meghatározó szerepet játszik az aroma és színanyagok kialakulásában, és kiemelkedő jelentőségü a bor karakterének formálásában (Jackson és Lombard, 1993).

A nappali hőmérséklet befolyásolja a színeződést, de a hűvös éjszakai hőmérsékleti feltételek még erőteljesebben hatnak rá (Singleton és Esau, 1969; Kliewer és Torres, 1972; Kliewer, 1973; Tomana et al., 1979; Fregoni és Pezzutto, 2000). A szőlő érési periódusában számított átlagos minimumhőmérséklettel (Cool Night Index - CNI) következtetni lehet egy-egy régió potenciális jellegzetességeire a bor másodlagos anyagcseretermékeire (polifenolokra, aromákra, színanyagokra) vonatkozóan (Tonietto és Carbonneau, 2004). A hideg éjszaka index értékei alapján létrehozott osztályokat az 8. táblázatban láthatjuk.

8. táblázat: Hideg éjszaka index értékei alapján létrehozott osztályok (Tonietto és Carbonneau, 2004)

\begin{tabular}{|c|c|c|}
\hline $\mathrm{CNI}\left[{ }^{\circ} \mathrm{C}\right]$ & & Besorolás \\
\hline $\mathrm{CNI}<12$ & Hideg éjszakák & $\mathrm{CNI}+2$ \\
\hline $12<\mathrm{CNI}<14$ & Hűvös éjszakák & $\mathrm{CNI}+1$ \\
\hline $14<\mathrm{CNI}<18$ & Meleg éjszakák & $\mathrm{CNI}-1$ \\
\hline $18<\mathrm{CNI}$ & Forró éjszakák & $\mathrm{CNI}-2$ \\
\hline
\end{tabular}

A kontinentális hatás mérésére fejlesztette ki Gladstones a kontinentalitás indikátort $(C O)$, ami a júliusi és a januári középhőmérséklet különbsége.

\section{Extremális indikátorok}

Az extremális indikátorok (9. táblázat) közül a $35^{\circ} \mathrm{C}$ feletti maximális hőmérsékletü extrém meleg napok száma $(N E H D)$, a $30{ }^{\circ} \mathrm{C}$ feletti maximális hőmérsékletủ meleg napok száma $(N H D)$ és a $25{ }^{\circ} \mathrm{C}$ feletti maximális hőmérsékletü nyári napok száma (NSD) a növényt ért hőstressz mértékéről nyújt információt. A klímaváltozás hatásának vizsgálatakor kiemelten fontos 
megvizsgálni, hogy a múltban hogyan változtak ezek az értékek, illetve a jövőben emelkedésüket vagy csökkenésüket várhatjuk-e.

A fagyos napok száma $(N F D)$ a $0{ }^{\circ} \mathrm{C}$ alatti minimumhőmérsékletủ napokat adja meg, míg a jeges napok száma (NID) a $\quad-10{ }^{\circ} \mathrm{C}$ alatti napokét. A szőlő különböző súlyosságú fagykockázatának szempontjából különösen fontos a $-8{ }^{\circ} \mathrm{C}$, illetve a $\quad-15^{\circ} \mathrm{C}$ alatti minimumhőmérsékletű napok száma, ezeket a szőlő fagyindex $(F 8 D)$, illetve a szőlő súlyos fagyindex $(F S 15 D)$ tartalmazza. Az NFD értéket a tavaszi, valamint az őszi fagyos napok számával összehasonlítva tájékozódhatunk arról, hogy ez utóbbiak milyen arányban vannak az éves értékhez képest. A jeges napok számából a téli fagykockázatra következtethetünk. Ha az NID értékek szignifikánsan csökkennek, akkor a fagykockázat is csökken, ami természetesen nem zárja ki a kis valószínűséggel előforduló, ám nagy károkat okozó események megjelenésének lehetőségét.

A tavaszi fagyos napok számának megadásakor (NSFD) azokat a napokat vesszük figyelembe március 1-je és május 31-e között, melyeken a minimumhőmérséklet kisebb, mint $0{ }^{\circ} \mathrm{C}$. A $0{ }^{\circ} \mathrm{C}$ és $-3{ }^{\circ} \mathrm{C}$ közötti lehülés ugyanis súlyosan károsítja az éppen kifakadt rügyeket, vagy már az intenzíven növekvő hajtásokat a rajtuk fejlödő virágzatokkal együtt (Hajdu és Borbásné Saskői, 2009).

Az őszi fagyos napok száma $(N F F D)$ a szeptember elseje és november 30 -a közötti $0^{\circ} \mathrm{C}$ alatti minimumhőmérsékletű napokat jelenti. A mérsékelt égövön, ahol kontinentális klíma uralkodik, gyakran korán beköszöntenek a fagyok. Ezek az ún. kora őszi fagyok lombhullás előtt érkeznek, lerövidítve a természetes vegetációt. Ekkor a középkései és kései érésű fajták tőkéin még érnek a szőlőfürtök és a szőlővesszők (Hajdu és Borbásné Saskői, 2009).

A tavaszi fagyindex meghatározására két indikátort ismertetünk. A Gladstones-féle tavaszi fagyindex $\left(S F I_{\text {Glad }}\right)$ esetében az áprilisi átlagos maximumhőmérsékletek és átlagos minimumhőmérsékletek átlagából az ugyanebben a hónapban mért minimális hőmérsékletet vonjuk ki, míg a Wolf-Boyer féle tavaszi fagyindexben $\left(S F I_{W B}\right)$ a minimumhőmérsékletek átlagát vonjuk ki. Az indikátorok szerkezetének oka, hogy nagyobb felmelegedés esetén enyhébb fagy is hasonló károkat tud okozni, mint hüvösebb időszakban egy súlyosabb fagy. Nagyobb $S F I_{\text {Glad }}$, illetve $S F I_{W B}$ értékek nagyobb fagykockázatot indikálnak. 
9. táblázat: A szőlőtermesztésben alkalmazott extremális indikátorok

\begin{tabular}{|c|c|}
\hline $\begin{array}{l}\text { Extrém indikátorok, jelölések, } \\
\text { mértékegységek, hivatkozások }\end{array}$ & Meghatározása \\
\hline $\begin{array}{l}\text { Extrém meleg napok száma } \\
\text { (Number of Extremely Hot Days - } \\
\text { NEHD, [nap], ápr. 1-okt. 31.) }\end{array}$ & Extrém meleg napok: $T_{\max }>35^{\circ} \mathrm{C}$ \\
\hline $\begin{array}{l}\text { Meleg napok száma (Number of } \\
\text { Hot Days - NHD, [nap], ápr. 1- } \\
\text { okt. 31.) }\end{array}$ & Meleg napok: $T_{\max }>30^{\circ} \mathrm{C}$ \\
\hline $\begin{array}{l}\text { Nyári napok száma (Number of } \\
\text { Summer Days - NSD, [nap], } \\
\text { ápr. 1- okt. 31.) }\end{array}$ & Nyári napok: $T_{\max }>25^{\circ} \mathrm{C}$ \\
\hline $\begin{array}{l}\text { Fagyos napok száma (Number of } \\
\text { Frost Days - NFD, [nap]) }\end{array}$ & Fagyos napok száma nov. 1- okt. 31.: $T_{\min }<0^{\circ} \mathrm{C}$ \\
\hline $\begin{array}{l}\text { Jeges napok száma (Number of Icy } \\
\text { Days - NID, [nap]) }\end{array}$ & Jeges napok száma nov. 1 - okt. $31: T_{\min }<-10^{\circ} \mathrm{C}$ \\
\hline $\begin{array}{l}\text { Szölö fagyindex (Vitis Frost Risk } \\
\text { Days, F8D, [nap]) }\end{array}$ & Szőlő fagyindex nov. 1- okt. $31: T_{\min }<-8^{\circ} \mathrm{C}$ \\
\hline $\begin{array}{l}\text { Szőlö súlyos fagyindex (Vitis } \\
\text { Serious Frost Risk Days, FS15D, } \\
\text { [nap]) }\end{array}$ & Szőlő súlyos fagyindex nov. 1- okt. $31: T_{\min }<-15^{\circ} \mathrm{C}$ \\
\hline $\begin{array}{l}\text { Tavaszi fagyos napok száma } \\
\text { (Number of Spring Frost Days - } \\
\text { NSFD, [nap], márc. 1- máj. 31.) }\end{array}$ & $\begin{array}{l}\text { Március elseje és május } 31 \text {-e közötti olyan napok száma, } \\
\text { amikor a minimumhömérséklet }<0^{\circ} \mathrm{C}\end{array}$ \\
\hline $\begin{array}{l}\text { Öszi fagyos napok száma } \\
\text { (Number of Fall Frost Days - } \\
\text { NFFD, [nap], szept.1- nov. 30.) }\end{array}$ & $\begin{array}{l}\text { Szeptember elseje és november } 30 \text {-a közötti olyan napok } \\
\text { száma, amikor a minimumhömérséklet }<0^{\circ} \mathrm{C}\end{array}$ \\
\hline $\begin{array}{l}\text { Gladstons-féle tavaszi fagyindex } \\
\text { (Spring Frost Index - SFI } I_{\text {Glad }},\left[{ }^{\circ} \mathrm{C}\right] \text {, } \\
\text { Gladstones, 2000) }\end{array}$ & $S F I_{\text {Glad,Ápr. }}=\frac{\underset{\text { Apr. }}{\text { Átlag } T_{\max }+\text { Átlag }_{\text {Apr. }} T_{\min }}}{2}-\min _{\text {Apr. }} T_{\min }$ \\
\hline $\begin{array}{l}\text { Wolf-Boyer féle tavaszi fagyindex } \\
\text { (Spring Frost Index }-S F I_{W B},\left[{ }^{\circ} \mathrm{C}\right] \text {, } \\
\text { Wolf and Boyer, 2003) }\end{array}$ & 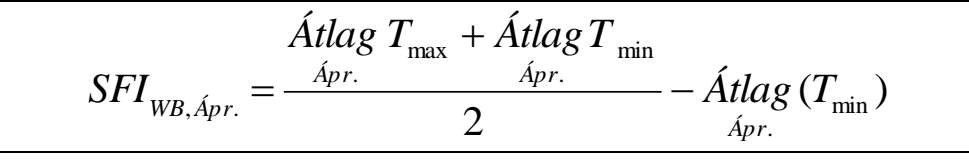 \\
\hline $\begin{array}{l}\text { Júliusi hőmérsékleti terjedelem } \\
\text { (Diurnal Range }-D R,\left[{ }^{\circ} \mathrm{C}\right] \text {, Hong } \\
\text { et al., 1992, Katz, 1988) }\end{array}$ & $D R=T_{\max , \text { Júl. }}-T_{\min , J u ́ l .}$ \\
\hline $\begin{array}{l}\text { Áprilisi átlagos napi hőingás } \\
\text { (Mean April Daily Range - } \\
M A D R,\left[{ }^{\circ} \mathrm{C}\right], \text { Smart és Dry, 1980) }\end{array}$ & $M A D R=\underset{A p r}{\operatorname{At} t a g}\left(T_{\max }-T_{\min }\right)$ \\
\hline $\begin{array}{l}\text { Szüreti átlagos napi hőingás } \\
\text { (Mean Harvest Daily Range- } \\
M H D R,\left[{ }^{\circ} \mathrm{C}\right], \text { Smart és Dry, 1980) }\end{array}$ & $M H D R=\underset{\text { Aug.15-Okt.15. }}{\text { Atlag }}\left(T_{\max }-T_{\min }\right)$ \\
\hline $\begin{array}{l}\text { Érésidei napi höingás összege } \\
\text { (Sum of Daily Temperature } \\
\text { Excursion - ET, }\left[{ }^{\circ} \mathrm{C}\right] \text {, Zorer, 2008) }\end{array}$ & $E T=\sum_{J u n .1 .}^{\text {Okt.31. }}\left(T_{\max }-T_{\min }\right)$ \\
\hline $\begin{array}{l}\text { Ribérau-Gayon-Peynaud Index } \\
(R G P \text {, } \\
\text { Jones és Davis, } 2000 \text { a b; Ribérau- } \\
\text { Gayon és Guimberteau, } 1996 \text { a) }\end{array}$ & $R G P=\sum_{i=\text { Ápr.1. }}^{\text {Okt.31. }} \max \left[\left(T_{a \text { atlag,i }}-10\right) ; 0\right]-$ Csapadék $_{i}$ \\
\hline
\end{tabular}


A hőmérsékleti terjedelem (DR) július hónap során a havi maximum- és minimumhőmérséklet közötti különbséget méri, vagyis értékeiből a havi hőmérsékletingadozásra következtethetünk. Túlságosan magas hőingás nagyobb stresszel jár a növény számára, túlságosan kicsi pedig az éjszakai lehülés kielégítetlen mértékére utalhat.

Az áprilisi átlagos napi hőingás $(M A D R)$ a rügyfakadás idején, a szüretidei átlagos napi hőingás $(M H D R)$ pedig a szüretet megelőző, illetve a szüret idején létrejövő hőmérsékletingadozásról ad információt.

Az érésidei napi hőmérsékletingadozás összege $(E T)$ a június 1-je és október 31-e közötti napi maximum- és minimumhőmérsékletek közötti különbségeket kumulálja, és így az érés és a szüret ideje alatti hőmérsékletingadozásról tájékoztat.

A Riberau-Gayon-Peynaud indexet $(R G P)$, melyet más néven becsült evapotranspirációs indexnek is neveznek, Bordeauxban használják a bor sav-cukor összetételének előzetes becslésére (Ribereau-Gayon et. al., 1975, 1976, Peynaud és Ribereau-Gayon, 1971). Jones és Davis (2000 a b), valamint Jones és Storchman (2001) számos fajta esetében megmutatták, hogy a becsült evapotranspirációs index értékével szoros korrelációban áll a gyümölcs szüreti cukorés savtartalma.

\section{Csapadék indikátorok}

$\mathrm{Az}$ éves csapadékmennyiség $(A R)$ egy átlagos, közelítő értéket ad, mely alapján meghatározható, hogy az adott termőhelyen elegendő csapadék hull-e a szőlő számára egy évben. Azonban ha arra vagyunk kíváncsiak, hogy nyáron, télen, a tenyészidőszakban, vagy akár a virágzás és az érés alatt mennyi csapadék jut a szőlőnek, akkor a nyári csapadékmennyiséget $(S R)$, a téli csapadékmennyiséget $(W R)$, a tenyészidőszak csapadékmennyiségét $(G S R)$, a virágzás ideje alatti csapadékmennyiséget $(B P R)$ és az érésidő alatti csapadékmennyiséget $(R P R)$ is számításba kell venni. A tenyészidőszak csapadékos napjainak száma (GSRD) szintén alapvető információt nyújt egy-egy termőhely lehetséges agroökológiai potenciáljához. A környezet páratartalma hat az asszimiláció mértékére, a cukor- és savképződésre, a bogyó tömegének alakulására. A túl sok nedvesség kitolja az érés idejét, a kevés nedvesség viszont akadályozza a fotoszintézist, csökkenti a cukor áramlását a bogyó felé, ami akadályozza az érést és a bogyó méretének gyarapodását (Kozma, 1991).

$\mathrm{Az}$ itt felsorolt éghajlati indikátorokon kívül a szakirodalomban még számos indikátort lelhetünk fel, és találkozhatunk azok alkalmazásaival. Ilyenek például a Branas-féle heliotermikus index (1946), a Dunkel-Kozma-Major-féle (1981) radiotermikus index, a csapadék-hőviszony index, a hidrotermikus koefficiens, a bioklimatikus index stb. (Kozma, 1991). Ezek a klimatikus indikátorok azonban olyan paramétereket is felhasználnak, melyeket a 
regionális klímamodellek napi becslései nem tartalmaznak, így a klímaváltozás hatásainak kutatásában kevésbé alkalmazhatóak, s emiatt közlésüktől el is tekintünk.

10. táblázat: A szőlőtermesztésben alkalmazott csapadék indikátorok

\begin{tabular}{|l|c|}
\multicolumn{1}{|c|}{$\begin{array}{c}\text { Csapadék indikátorok, jelölések, } \\
\text { mértékegységek, hivatkozások }\end{array}$} & \multicolumn{1}{c|}{ Meghatározása } \\
\hline $\begin{array}{l}\text { Éves csapadékmennyiség (Annual rainfall - } \\
\text { AR, [mm], van Bruggen and Semenov, 1999, } \\
\text { Kellett et al., 2005) }\end{array}$ & $\begin{array}{c}\text { Január 1-töl december 31-ig lehullott } \\
\text { csapadék mennyisége mm-ben }\end{array}$ \\
\hline $\begin{array}{l}\text { Nyári csapadékmennyiség (Summer rainfall - } \\
\text { SR, [mm], Nicholas et al. 1994) }\end{array}$ & $\begin{array}{c}\text { Június, július hónapokban hullott csapadék } \\
\text { mennyisége mm-ben }\end{array}$ \\
\hline $\begin{array}{l}\text { Téli csapadék (Winter Precipitation - WR, } \\
{[\mathrm{mm}] \text { ) }}\end{array}$ & $\begin{array}{c}\text { November elsejétől március 31-ig hullott } \\
\text { csapadék mennyisége mm-ben }\end{array}$ \\
\hline $\begin{array}{l}\text { Tenyészidőszak csapadéka (Growing Season } \\
\text { Precipitation - GSR, [mm], Sabatelli és } \\
\text { Stendardi,1981, Salinari et al., 2006) }\end{array}$ & $\begin{array}{c}\text { Április elsejétől október 31-ig hullott összes } \\
\text { csapadék mennyisége mm-ben }\end{array}$ \\
\hline $\begin{array}{l}\text { Virágzáskori csapadék (Bloom Period } \\
\text { Precipitation - BPR, [mm]) }\end{array}$ & $\begin{array}{c}\text { Május 15-e és június 15-e között lehullott } \\
\text { csapadék mennyisége mm-ben }\end{array}$ \\
\hline $\begin{array}{l}\text { Erésidö alatti csapadék (Ripening Period } \\
\text { Precipitation - RPR, [mm], Allen C. G., } \\
\text { 2005) }\end{array}$ & $\begin{array}{c}\text { Augusztus 15-e és október 15-e között } \\
\text { lehullott csapadék mennyisége mm-ben }\end{array}$ \\
\hline $\begin{array}{l}\text { A tenyészidöszak csapadékos napjainak } \\
\text { száma (Number of Growing Season Rain } \\
\text { Days - GSRD, [nap], Salinari et al., 2006) }\end{array}$ & $\begin{array}{c}\text { Április elsejétől október 31-ig az összes } \\
\text { csapadékos nap száma }\end{array}$ \\
\hline
\end{tabular}

\subsubsection{Megfigyelések, prognózisok a világ különbözö tájairól}

Számos európai szőlőtermesztő régióban évszázadok óta feljegyezték a hőmérsékleti megfigyelésekkel együtt az ezektől nagyban függő szüreti adatokat. Ezek az adatok a regionális hőmérsékleti anomáliák egyik leghosszabb idősorát nyújthatják kronológiai bizonytalanságok nélkül. Franciaországban, Burgundia borvidékein a szüreti időpontokat gondosan regisztrálták a plébániákon és a községi archívumokban a korai 13. század óta. Chuine és munkatársai (2004) egy javított és frissített szüreti adatsort készítettek a burgundiai borvidékről az 1370 és 2003 közötti értékeket feldolgozva, rekonstruálva a Kelet-Franciaországban előfordult tavaszi-nyári hőmérsékleti anomáliákat. A historikus megfigyelésekre egy folyamatalapú fenológiai modellt használtak. A vizsgálatot a Pinot noir fajtára végezték el, amely Burgundia kimelt fontosságú fajtája, és legalább a 14. század óta folyamatosan termesztik ezen a borvidéken. A vizsgálat eredményeként több meleg periódust is meghatároztak a több mint 630 éves időintervallum alatt. Például az 1520-as években, valamint az 1630-as és 1680-as évek közötti periódus melegebb volt, mint a 20. század vége. Az 1680-as évek magas hőmérsékleti eseményeit egy lehűlés követte, ami az 1750-es években kulminálódott. Példátlan esemény a 2003-as év nyarán bekövetkezett, bizonyított anomália. Ez $5,86^{\circ} \mathrm{C}$ fokkal melegebb volt, mint a referencia-időszak (1961-1990) átlaga, a következő legmagasabb hőmérsékletű anomália a teljes perióduson $4,10^{\circ} \mathrm{C}$ volt, 1523-ban (Chuine et al., 2004). 
Az utóbbi évtizedek melegedésének mértéke erősen eltér a régiók között. A világ 27 legjelentősebb borvidékeinek hőmérsékleti adatait elemezve Jones és munkatársai (2005 a), azt tapasztalták, hogy az elmúlt 50 évben átlagosan $1,3^{\circ} \mathrm{C}$ fokkal emelkedett a tenyészidőszakok hőmérséklete. Nagyobb felmelegedés volt az USA nyugati részén és Európában, kisebb a felmelegedés Chilében, Dél-Afrikában és Ausztráliában. $2,5^{\circ} \mathrm{C}$ foknál nagyobb átlagos hőmérséklet-emelkedés következett be az Ibériai-félszigeten, Dél-Franciaországban, valamint Washington állam egyes részein és Kaliforniában.

A Globális Historikus Éghajlati Hálózat (GHCM - Global Historical Climatology Network) archív adatait, a jövő éghajlatainak modellszimulációit (HadCM3 A2 szcenárió esetén) és az évjáratok értékelését felhasználva Jones és munkatársai (2005) négy pontban fogalmazták meg következtetéseiket a világ minőségi bortermelése és a klímaváltozás vonatkozásában:

1. 1950-től 1999-ig a vegetációs időszak átlagos hőmérséklet-növekedése a világ legjelentősebb borvidékein átlagosan mintegy $1,26^{\circ} \mathrm{C}$.

2. Míg a lehető legjobb minőségre való törekvések kétségtelenül hozzájárultak a jobb szőlészeti és borászati gyakorlathoz, a régiók többségében olyan éghajlati változásokat figyeltek meg, melyek az évjáratok minőségi arányait jelentősen befolyásolták. Az évjárathatás 10-60 \%-a magyarázható a vegetációs időszak hőmérséklet-változásaival. Az ennek legjobban kitett területek a hideg éghajlati övben találhatóak, elsősorban a németországi Mosel és Rajna völgyében.

3.12 bortermelő vidék vegetációs időszakának hőmérsékleti paraméterei már meghaladják az optimális értékeket, ami már negatív évjárathatással jár. Emellett számos más borvidék éghajlata az optimum felé közelít, egyre jobb kilátást nyújtva a régiónak.

4. A HadCM3 éghajlati modell a 2021-2050-es periódusra a legkiválóbb borvidékek hőmérsékleti paramétereire átlagosan $1,24{ }^{\circ} \mathrm{C}$-os melegedést prognosztizál az 1951-2000-es időszakhoz képest. Míg a 20. század megfigyelt melegedése főleg a minőségi bortermelésnek volt előnyös világszerte, a jövőbeli éghajlatváltozás hatása erősen heterogén lesz fajták és régiók esetében. Néhány régióban a melegedés meghaladhatja a fajtaspecifikus optimumhőmérséklet küszöbét, így a kiegyensúlyozott gyümölcsérés a jelenlegi bortermelési módok mellett a későbbiekben nem feltétlenül lesz biztosítható, ami nagy kihívást jelent majd a hagyományos minőségi bortermelők számára (Jones et al., 2005).

Jones és munkatársai (2005) a szőlő fenológiájának változását és az éghajlatváltozással összefüggő kapcsolatát is vizsgálták kilenc európai ültetvényben. 1952 és 2004 közötti időszakból származó fenológiai idősorok felhasználásával összefoglalták a megfigyelt fenológiai jellegzetességeket, valamint a változás irányát számos fajta és régió esetében Franciaországban (Elzász, Reims, Burgundia, Bordeaux), Olaszországban (Conegliano), Spanyolországban 
(Valladolid, Ponteverda), Németországban (Geisenheim) és Szlovákiában (Dolné Plachtince). A fenológiai jellemzők és trendek elemzéséhez egyszerü leíró statisztikákat és lineáris trendszámításokat használtak. Eredményeik:

- a fenológiai események szignifikánsan korábbi előfordulása (8-16 nappal);

- rövidebb intervallumok az egyes események között (4-14 nappal) a legtöbb régióban;

- a változások jellemzően nagyobbak a minimum-hőmérsékletekben, mint a maximumhömérsékletekben;

- $1,7^{\circ} \mathrm{C}$ fokos átlaghőmérséklet-emelkedés a tenyészidőszakban, közel 300 egységnyi hatásos hőösszeg és Huglin-index érték növekedés az elmúlt 50 évben;

- a változások egyértelmúen befolyásolják a szőlö fenológiai ciklusát.

Cahill és munkatársai (2007) Kaliforniában a borszőlőfajták termésmennyiségét és minőségét vizsgálták a klímaváltozásnak a szőlészeti-borászati ágazatra vonatkozó lehetséges hatásainak a leírására, valamint az alkalmazkodási stratégiák rangsorolására. Saját fejlesztésü modelleket használtak historikus éghajlati és termésmennyiségi adatokra, majd ezeket alkalmazták klímamodellekre és különböző éghajlati szcenáriókra, hogy megbecsüljék a jövőbeli kaliforniai borszőlő-hozamokat. Arra a következtetésre jutottak, hogy a térségükre elörevetített hömérséklet-emelkedés miatt az elkövetkező évszázad során számos terület lekerülhet a jelenleg optimális klimatikus feltételekkel rendelkező régiók listájáról, ami az eddig megszokott minőségi bortermelést helyi lehetőségeit megkérdőjelezi.

Ausztráliában a szőlészeti-borászati ágazat a leggyorsabban fejlődő vidéki iparág, több mint 5 milliárd dollár éves bruttó bevétellel, melynek több mint fele export. Az előrejelzések szerint 2030-ra 0,3 és $1,7^{\circ} \mathrm{C}$ fok közötti éves átlaghőmérséklet-emelkedés várható a térség számos szőlőtermesztő vidékén. 2070-re az éves átlagos hőmérséklet-emelkedés már 0,8 és $5,2^{\circ} \mathrm{C}$ között lesz. Az előrejelzett hőmérséklet-emelkedés nem lesz egységes az Ausztrál kontinensen sem. Nagyobb melegedés lesz a kontinens központi régióiban és kisebb a partközeli területeken. Webb és munkatársai (2005) a hőmérséklet-emelkedés hatását vizsgálták ausztráliai szőlöültetvényekben regionális klímamodellek alapján. A tanulmány fö célja az volt, hogy a hőmérséklet és a szőlőminőség, valamint -mennyiség közötti kapcsolatot vizsgálják. Elemzéseik szerint a növekvő hőmérsékletnek negatív hatása lesz a szőlő minőségére, de a hozam növekedni fog. Az összefüggést regressziós modellekkel igazolták az összes termesztett prémium fajtára, bemutatva a fajták sajátos hőmérséklet-érzékenységét, végül adott melegedést feltételezve azonosították a szőlőtermesztésre a jövőben alkalmas régiókat.

Új-Zélandon az IPCC 2007-es jelentése 2050-re a levegő átlaghőmérsékletének 1-2 ${ }^{\circ} \mathrm{C}$ fokos emelkedését prognosztizálja, és egyre szélsőségesebb éghajlati események bekövetkezése várható. Az ország keleti felére az átlagosnál gyakoribb és hosszabb szárazságot becsülnek. Az 
elmúlt 75 éven keresztül Marlborough tartomány borvidékein az éves átlagos hőmérséklet $12,4^{\circ} \mathrm{C}$ fokról $13,3^{\circ} \mathrm{C}$-ra emelkedett. Ha ez a trend tovább folytatódik, komoly hatása lesz a szőlőtermesztésre, különösen a régió vízhiányos részein. A kevesebb csapadék további beruházási igényeket támaszt a hiányos vízforrással rendelkező régiókban (Greven et al., 2007).

Kínában 2004-ben 450000 hektáronon termesztettek szőlőt. Ebből a kiváló minőségü szőlőt termő területek jóval kisebb területet foglalnak el. Li és munkatársai (2007) Kína 14 szőlőtermesztő régióját választották ki, és országos meteorológiai adatok elemzésére alapozva az elmúlt 45 évre vonatkozóan indikátorokként vizsgálták a fagymentes napokat, a takarási vonalat (azt a határvonalat, ahol a szőlőt már takarni szükséges, mivel télen a hőmérséklet minimuma $15^{\circ} \mathrm{C}$ alá süllyed), a tenyészidőszak átlagos hőmérsékletét és a tenyészidőszak hatásos akkumulált hőösszegét. Ezek az adatok jól tükrözték a globális felmelegedés hatását Kína szőlőtermesztésére. Munkájuk során az alábbi következtetésekre jutottak:

5. Az elmúlt 45 évben, különösen az 1980-as évek után a fagymentes napok száma észrevehetően nőtt, a szőlő tenyészidőszaka meghosszabbodott, a fagykár valószínűsége csökkent. A takarási vonal észak felé húzódott, és a takarást igénylő területek összezsugorodtak.

6. A fenti indikátorok eloszlása a régiókban igen különbözőképpen változott Kína változatos terepviszonyai miatt. A fagymentes napok száma a sík területeken (pl. alföld és fennsík) szignifikánsan elmelkedtek, ám még jelentősebb változás tapasztalható azokon a területeken, ahol a talajszint hirtelen emelkedik.

7. Az elkövetkező 50 évre készült jelentésük szerint Kína legtöbb területén termeszthető lesz a szőlő, kivéve néhány területet Észak-Kínában.

8. Mivel Kína a kontinentális monszun éghajlati típusba tartozik, nyáron a hőmérséklet magasabb, mint ugyanennek a földrajzi szélességnek a többi területén. Így a szőlőtermesztés alkalmasságának eldöntéséhez az átlaghőmérsékletet és a hatásos hőösszeget alkalmazták mint indexeket. Még ha a szőlőtermesztés követelményei meg is felelnek az átlaghőmérséklet és a hatásos hőösszeg kritériumainak, először a fagymentes napok számát kell figyelembe venni, hogy a szőlőtermesztés alkalmassága bizonyítható legyen (Li et al., 2007).

\subsubsection{Hazai tapasztalatok és kilátások}

Magyarországon Kőszeg városa rendelkezik egyedülállóan hosszú szőlőfenológiai feljegyzésekkel. A Szőlő Jövésnek Könyvébe 1740 óta minden év Szent György napján bevezetik a fakadó szőlő fenológiai stádiumát, azaz egy kézzel festett képet készítenek a hajnalban szedett kőszegi szőlőhajtások április 24-ei állapotáról. Mivel azonban nem a rügyfakadás konkrét időpontja van feljegyezve, így a hagyományos matematikai modellek számára ilyen formában ezek az adatok sajnos nem használhatóak fel. 
Hajdu Edit és munkatársai 45 éves meteorológiai és rügyfakadási adatokat gyüjtöttek össze 1962 és 2006 között, majd értékelték abból a célból, hogy a szőlőre és környezetére ható éghajlatot, időjárást és annak jellemzőit bemutassák. Kecskeméten az egykori FVM Szőlészeti és Borászati Kutatóintézetében, Katonatelepen és Miklóstelepen dr. Füri József vezetésével 1962ben állították fel az Európában is szabványos meteorológiai észlelőkertet, melyben léghőmérsékletet, talaj hőmérsékletet $2-50 \mathrm{~cm}$ mélységig, a szélirányt és a szél erősségét, a lehullott téli és nyári csapadék formáját és mennyiségét, a levegő nedvességét, valamint a napsugárzást mérték. Következtetéseik feltehetően nemcsak a Kecskeméten és környékén található szőlöültetvényekre, hanem mindazokra a magyar borvidékekre vonatkozhatnak, ahol kontinentális klíma uralkodik. Ezeken a borvidékeken az abiotikus stresszhatások fokozottan jelentkeztek az 1990-es évektől, melyeket a mérési adatok is alátámasztanak. Abiotikus stresszhatásoknak nevezzük a tavaszi fagyokat, a száraz aszályos nyarakat, az egyszerre lezúduló nagy mennyiségű csapadékot, a következtében kialakuló talajeróziót, áradásokat és belvizeket. Ennek következményei lehetnek a korábbra tolódó rügyfakadás, a tavaszi fagykárok, a virágok hiányos termékenyülése, aszályos nyarakon a hősokk és napperzselés. A túl sok csapadék a szőlő betegségeit, a csapadékhiány a rovarok felszaporodását, károsítását és a szőlő rendellenes tápanyag-gazdálkodását fokozta. Az időjárási elemek és a szőlönövény közötti kapcsolatot nagymértékben befolyásolta a fajta és a művelésmód (Hajdu és Borbásné Saskői, 2009).

Az utóbbi években egyre gyakrabban tapasztalhatjuk azt, hogy a szőlő hajtásai a májusi melegben a megszokottnál gyorsabban fejlödnek. A virágok az intenzív hajtásnövekedés eredményeként a megszokottnál több nappal korábban nyílhatnak. A többnyire kedvező körülmények hatására lerövidül a virágnyílás időszaka; javulnak a megporzás és a megtermékenyülés feltételei (a jobb fényviszonyok egyébként a rügyek termékenységét is fokozzák). Nemcsak a virágzás, a termésérés ideje is korábbra tevődik át. Az átlaghőmérséklet emelkedésével javulhat a beérési mustfok. A nyári hónapok középhőmérsékletének $1^{\circ} \mathrm{C}$-kal való emelkedése a must cukortartalmában literenként 20 - 30 gramm többletet, savtartalmában 2-3 ezrelék csökkenést jelenthet. A meleg időben intenzívvé válik a színanyagok képződése és a szabad aminosavak lekötődése (Kozma, 1991; Zanathy, 2008).

Magyarországon a tenyészidőszakban lehulló 500-600 mm átlagos évi csapadékmennyiség elegendő a szőlőnek (Bényei et al., 1999). A csapadék évi összegben csak kevéssel csökken, de az éven belüli megoszlása igen előnytelenül alakul. A jövőben várhatóan nyáron és ősszel, amikor a természet amúgy is kiszárad, a csapadék tovább csökken, s ezt a téli-tavaszi többlet csak részben ellensúlyozza. Az egyes szőlőfajták szárazságtürő képessége különböző, így eltérő mennyiségi és minőségi teljesítménnyel reagálnak a vízhiányos körülményekre. A csapadék föként nyári csökkenéséből, a napfénytartam és a hőmérséklet emelkedéséből egyértelműen 
következik az aszályok gyakoriságának növekedése (Teszlák et al., 2009). Egy korábbi számítás szerint (Mika, 1988) az 1881 és 1980 közötti időszak adatai alapján már 0,5 ${ }^{\circ} \mathrm{C}$ globális melegedéshez a 30\%-os talajnedvesség-küszöb alá eső hónapok számának csaknem 60\%-os megnövekedése tartozott. Ezt az is elöidézi, hogy a kevesebb csapadék úgy áll elő, hogy jóval ritkábban fordul elő csapadék, viszont a csapadékos napok átlagos hozama egy kicsit növekszik. Csakhogy a rövid idő alatt hulló nagy csapadék egy része elfolyik, nem hasznosul (Teszlák et al., 2009).

A nyári aszály következtében a növény növekedése leáll, kisebb fürt- és bogyótömeg várható. A szőlő várható termőképességének értékelésekor számításba kell venni a túl erős napsugárzás, a hosszan tartó hőség, és a levegő alacsony páratartalmának káros hatásait is (Hajdu és Borbásné Saskői, 2009). Hazánkban a több napfény és hő hatására magasabb alkoholtartalmú, színanyagban gazdagabb vörösborok készíthetők. Megnő azonban az esélye annak, hogy egyes fehérborszőlő-fajták terméséből jellegtelen, savban szegény, a kelleténél nagyobb alkoholtartalmú, de illat- és zamatanyagban szegényebb borok készülnek. Ezért jelentősen átalakulhat a fajtaszerkezet: a csemegeszőlő- és kései érésü borszőlőfajták nagyobb szerepet kaphatnak, és nőhet a vörösbort adó fajták aránya (Zanathy, 2008).

Vélhetőleg azok a szőlőfajták adnak majd kiemelkedő teljesítményt, melyek jól bírják a szárazságot (Cabernet sauvignon, Karát, Kármin, Kövidinka, Sauvignon blanc, Zengő) és a fagyot (Bianca, Cabernet franc, Chardonnay, Rajnai rizling, Duna gyöngye, Cserszegi füszeres, Generosa, Zalagyöngye) (Bényei et al., 1999; Hajdu és Borbásné Saskői, 2009). Várható a szőlöültetvények gyorsabb elöregedése, várható legmagasabb életkoruk csökkenése is. A melegebb és szárazabb éghajlat a termesztéstechnológia megváltoztatását is szükségessé teszi: ÉD irányú sorvezetés, magasabb tőszám, kisebb fürtterhelés, alacsonyabb művelésmód, talajtakarás. Fokozott figyelmet kell fordítani a vízellátottságra, a termésbiztonság növelése érdekében érdemes az öntözőrendszer kiépítése, a gépesítettséget az eddiginél magasabb színvonalúra indokolt emelni (Harnos et al., 2008).

A szélsőséges időjárási jelenségek gyakoribbá válásával mind több kárt okoznak majd a termésben a heves esőzések, szélviharok és jégesők. A korábbi érés miatt az eddigieket felülmúló darázskártétellel kell számolnunk. Eddig nem tapasztalt növényvédelmi problémákkal is szembe kell néznünk. A legnagyobb nehézséget minden bizonnyal a déli szőlőtermesztő országok szőlőkárosítóinak a megjelenése jelenti majd (Zanathy, 2008). Példa erre a Scaphoideus titanus kabócafaj hazai megjelenése. A kabóca közvetlen károsítása nem jelentős, viszont súlyos gazdasági kárt okoz a szőlő aranyszínű sárgasága (Flavescence dorée) fitoplazma terjesztésével, melynek specifikus vektora ez a kabócafaj (Zsolnai, 2006). 


\section{ANYAG ÉS MÓDSZEREK}

\subsection{A kísérleti adatok felvételezésének helyszínei}

A modellezéshez felhasznált adatok két helyről származnak. A helvéciai adatsort Pernesz György, a Nemzeti Élelmiszerlánc-biztonsági Hivatal (korábban Mezőgazdasági Szakigazgatási Hivatal) -továbbiakban NÉBIH- Szőlö-Gyümölcs Fajtakísérleti Osztályának vezetője ajánlotta fel, azzal a céllal, hogy a kísérleti állomás fajtakísérleteiből származó adatokat esetleges fenológiai változások kimutatására felhasználjuk. Az adatok kiértékelése után célunk volt eredményeinket megerősíteni más ültetvényekből származó hosszabb adatsorokkal is. Így jutottunk hozzá a Kecskemétről származó adatokhoz, melyet Dr. Hajdu Edit bocsájtott a rendelkezésünkre.

Mindkét adatsorunk a Duna Borrégión belül a Kunsági borvidékről származik (8. ábra). A Duna Borrégió Magyarország legnagyobb szőlő- és bortermelő tájegysége, melyet az Alföldi termőtájon található Csongrádi-, Hajós-Bajai és Kunsági Borvidékek Hegyközségi Tanácsai alapították 2002. év elején. A régió a három borvidék hegyközségi tanácsainak konzultív szerve. Területileg Magyarország középső részén, a Duna és Tisza folyók által meghatározottan, három borvidék, a Csongrádi-, a Hajós-Bajai valamint a Kunsági borvidék területét foglalja magában. A régió öt megye - Bács-Kiskun, Csongrád, Heves, Jász-Nagykun-Szolnok és Pest megye - és négy statisztikai régió dél-alföldi, észak-alföldi, észak-magyarországi és a központi - területét érinti több-kevesebb mértékben.

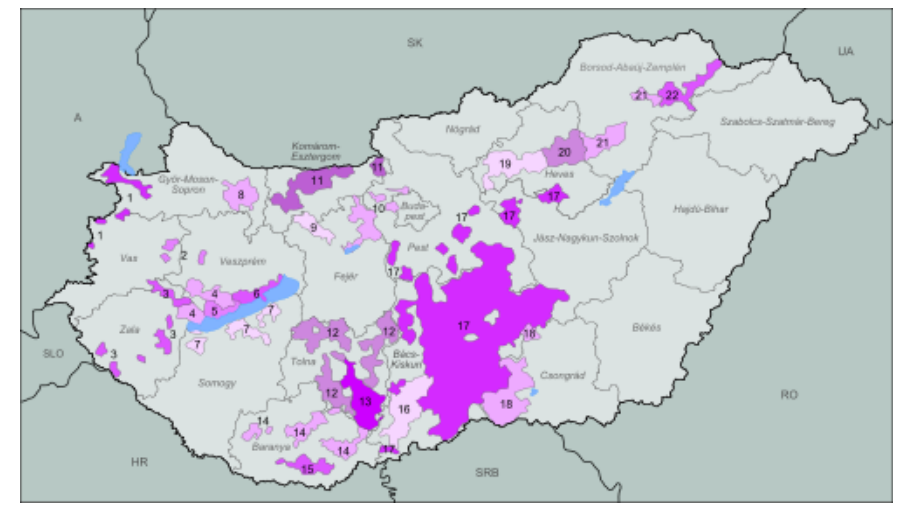

8. ábra: Magyarország borvidékei, a 17-es számú a Kunsági borvidék (http://hu.wikipedia.org/wiki/Bor_(ital)

A Duna Borrégió területére jellemző az immunis meszes homoktalaj, változó minőségü altalajjal, de jelentős területen található lösz, öntéstalaj és a gödöllői dombság déli nyúlványainak kötött talaja is. Az immunis homoktalajon zömében saját gyökéren él a szőlő.

A termelt szőlők fajtaösszetételében meghatározó, mintegy $70 \%$ a fehérbor-szőlő fajták aránya, $25 \%$ a vörösbort adó fajtáké, de ez borvidékenként jelentősen eltér. A maradék öt százalékot a csemegeszőlő fajták teszik ki. Több mint 70 a termesztett szőlőfajták száma, 
ugyanakkor a terület $77 \%$-át 15 olyan fajta foglalja el, melynek a termőterülete meghaladja az 500 hektárt, de például Kékfrankos szölőt több mint 3500 hektáron szüretelnek. Az említett 15 fajta nagyobbik része hungarikum (Borvidéki értesítő, 2003).

Az adatok forrásául szolgáló helvéciai és kecskeméti szőlöültetvények a dél-alföldi régióban, a Kunsági borvidék Kecskemét-Kiskunfélegyháza körzetéhez tartoznak. A Kunsági borvidékre a dunai eredetü, meszes homokjellemző. Az eredetileg kialakult mezőségi és réti talajokat többnyire lepelhomok takarja. Gyakoriak a sülevényes, humuszban szegény, homokbuckás területek. A talajvízszint általában magas (2-5 m).

A 2000-2004 között felvételezett adatok a Nemzeti Élelmiszerbiztonsági Hivatal Helvéciai Kísérleti Állomásáról származik.

A kecskeméti kísérlet adatok felvételezésének helyszíne a Budapesti Corvinus Egyetem Szőlészeti és Borászati Intézetének Kecskeméti Kutatóállomása, Katonatelepen. A termőhelyi kataszter szerinti besorolás II/2 osztály/193./8. számú felvételezési egység. Az ültetvény tengerszint feletti magassága 122 m. A terület kitettsége: síkvidék.

\subsubsection{A kísérleti ültevény talajadottságai}

\section{Helvécia}

NÉBIH Kísérleti Telephelye Helvécián található, a dél-alföldi régióban. Helvécia a Duna borrégión belül a Kunsági borvidék része. Termőföldje homokos, alacsony, 0,34 \%-os humusztartalommal (Pernesz, 2004). Arany-féle kötöttségi értéke 27. Gyengén lúgos kémhatású, $\mathrm{pH} 7,7-7,8$.

\section{Kecskemét}

A kecskeméti termőhely talajtípusa humuszos homok, a talajképző kőzet alluviális és glaciális üledék. Szénsavas meszet tartalmaz. A talaj fizikai félesége homok. Nagy víznyelésü, gyenge vízraktározó és víztartó talaj. Talajvíz a növény által elérhető közelségben nincs. Humusztartalom 50-100 t/ha. A termőréteg vastagásga kisebb, mint $100 \mathrm{~cm}$. A talaj homogénnek tekinthető, 60-70 \%-ban egyöntetü. Defláció veszély nincs.

\subsubsection{A kísérleti ültetvények jellemzése}

\section{Helvécia}

A vizsgálat alanyául szolgáló parcellákat eredetileg alapfajták és klónjaik összehasonlítására, értékelésére hozták létre. Ennek megfelelően, minden parcella 4 db 150 m hosszú sorból áll. Minden sor 6 részre van bontva, melyben 6 darab, lehetőleg egy fajtakörbe tartozó alapfajta és ennek klónjai vannak eltelepítve összehasonlítás céljából oly módon, hogy sorrendjüket a 4 sorban keverve alakították ki. Tehát ugyanarra szakaszra nem kerül újra ugyanaz a fajta vagy 
klón. Minden fajtából illetve klónból 25-25 tőke található minden sorban. A sortávolság $3 \mathrm{~m}$, a tőtávolság $1 \mathrm{~m}$, így a tenyészterület $3 \mathrm{~m}^{2} /$ tőke.

A sorok É-D irányúak. Az egysíkú támberendezést fa végoszlopokkal és $100 \mathrm{~cm}$ magas kartartó huzalokkal létesítették. A tőkék kordonmüvelésűek, egy $100 \mathrm{~cm}$ magasságú tőketörzsböl és egy vízszintesen rögzített tőkekarból állnak. A metszésmód csercsapos váltómetszés. Minden fajtát és klónt ugyanarra az alanyra oltották, hogy a kísérlet eredményeit ne befolyásolja, nevezetesen a Teleki 5C alanyra.

Kecskemét

A vizsgált ültetvény parcelláiban a sorok hossza $180 \mathrm{~m}$, az ültetvény sürüsége 10 tőke/parcella. A sortávolság $3 \mathrm{~m}$, a tőtávolság 1,2 m, így a tőkék tenyészterülete $3,6 \mathrm{~m}^{2}$. A sorok vezetése ÉNY - DK irányú. A támberendezést fa végoszlopokkal és fakaróhoz rögzített rozsdamentes acélhuzalokkal létesítették. A végoszlopok hossza 2,8 m, ebböl $70 \mathrm{~cm}$ a talajba süllyesztettek. A támberendezés magassága 2,1 m. A tőkék magas kordonmüvelésüek, $120 \mathrm{~cm}$-es törzsmagassággal. 2000-ig a kordonkarokon Sylvoz metszést, 2001-től ernyőmüvelést alkalmaztak, szálvesszős metszésmóddal, két szálvessző meghagyásával. Az ültetvény homok területen van, ahol nincs filoxéravész, ezért saját gyökerü szaporítóanyaggal történt a fajták telepítése.

\subsubsection{A kísérleti ültetvények kezeltsége}

\section{Helvécia}

Az vizsgált ültetvényt 1997-ben telepítették. A telepítés évében a területet szerves trágyával töltötték fel. Az ültetvény ezen felül tápanyagpótlást nem kapott. A sorközt kultivátorozással tartják gyommentesen, a soralját kapálással és/vagy vegyszeres gyomirtással kezelik. A növényvédelmet tervszerűen végzik, lisztharmat és peronoszpóra ellen csak járványveszélyes időben kellett védekezni. A betakarítás kézi szedéssel, ládával történik.

\section{Kecskemét}

A vizsgált ültetvényeket 1987-ben telepítették. A tápanyagutánpótlás talaj-és levélanalízis alapján történik. Ezt kiegészíti a növényvédelmi permetezéssel egyidőben kijuttatott Wuxal lombtrágya. A fitotechnikai müveletek közül évi három törzstisztítást, egy hajtásválogatást, két csonkázást és háromszor hajtásigazítást végeznek.

Gyomírtást évente öt alkalommal végezne tárcsázással, a korábbi években a tárcsázást kétszeri talajmarózás is kiegészítette. A sorok gyomírtását 1995-ig kézzel végezték, 1996-tól viszont vegyszeres gyomírtást alklamaznak. A kísérleti ültetvényeket átlagosan évente nyolc permetezésben részesítik, kombináltan a gombabetegségekkel és kártevőkkel. A különlegesen járványos években, pl. 1995-ben, a permetezések száma 12 volt. 
A betakarítás a gépi és kézi szüret kimbinációja, vagyis a szüreti munkákat kézzel végezik, a leszüretelt termést géppel szállítják a feldolgozóba.

\subsection{A vizsgálat ideje, az évjáratok jellemzése}

A meteorológiai adatok az Országos Meteorológiai Szolgálat Kecskeméttől 15 km-re lévő, 1973 óta működő K-puszta mérőállomásáról (48 58' N, 19³3' E, 126 m) származnak. A mérőhely tagja a Meteorológiai Világszervezet és az EMEP hálózatának, kalibrálása és karbantartása a vonatkozó WMO ajánlások szerint történik. A mérőhely típusa: QLC-50 automata meteorológiai állomás, 10 percenkénti adatközléssel (hőmérséklet, szélirány, sebesség, légnedvesség, csapadékösszeg).

\section{Helvécia 1999 öszétöl 2004 öszéig}

A helvéciai fenológiai adatok 2000 és 2004 között lettek feljegyezve. Az öt évjárat meteorológiai jellemzéséhez a Helvéciához legközelebb álló OMSz méröállomás adatait használtuk fel.

A 2000 és 2004 között mért hömérsékleti és csapadék adatok alapján a következők állapíthatók meg. A téli hidegösszegek alapján (9. ábra) a leghidegebb tél 2002-2003-ban volt (433 ${ }^{\circ} \mathrm{C}$ fagypont alatti átlaghőmérséklet-összeggel), s ebben az évben köszöntött be legkorábban az első fagyos éjszaka (2003.10.16.). A második helyen a 2001-2002-es év áll $247{ }^{\circ} \mathrm{C}$ fagypont alatti hidegösszeggel, de a legkésőbb érkező fagyos napokkal (2002. 12. 08-10). Az 1999-2000es és 2003-2004-es évek hidegösszeg értékei közel azonosak $\left(138,5^{\circ} \mathrm{C}\right.$ és $\left.129,5^{\circ} \mathrm{C}\right)$, az első $0{ }^{\circ} \mathrm{C}$ alatti hőmérsékletet 2000-ben október 21-én, 2004-ben november 15-én mérték. A 2000-2001-es év a legenyhébb telet produkálta (téli hidegösszeg $74,5^{\circ} \mathrm{C}$ ).

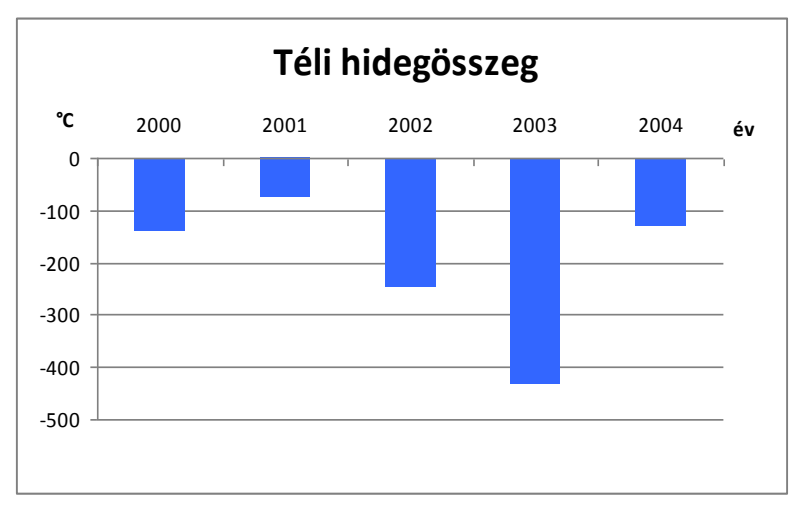

9. ábra: A fagypont alatti átlaghőmérséklet-összegek Helvécián 1999-2000, 2000-2001, 20012002, 2002-2003, 2003-2004 telén

A legmelegebb nyarak 2003-ban (1161 ${ }^{\circ} \mathrm{C}$ nyári hőösszeg), 2002-ben (1087 ${ }^{\circ} \mathrm{C}$ nyári höösszeg), illetve 2001 -ben $\left(990,5^{\circ} \mathrm{C}\right.$ nyári höösszeg) voltak a $10^{\circ} \mathrm{C}$ feletti átlaghőmérsékletösszegek alapján (10. ábra). Tehát a leghidegebb tél és a legmelegebb nyár egyazon évjárathoz, a 2003-ashoz kapcsolódik. Ezeket az éveket követi a 2004-es év $902{ }^{\circ} \mathrm{C}$ nyári höösszeggel, végül a 
leghüvösebb nyár a 2000 -es volt, mintegy feleakkora höösszeggel $\left(534,5^{\circ} \mathrm{C}\right)$, mint a 2002 -es és 2003-as évek.

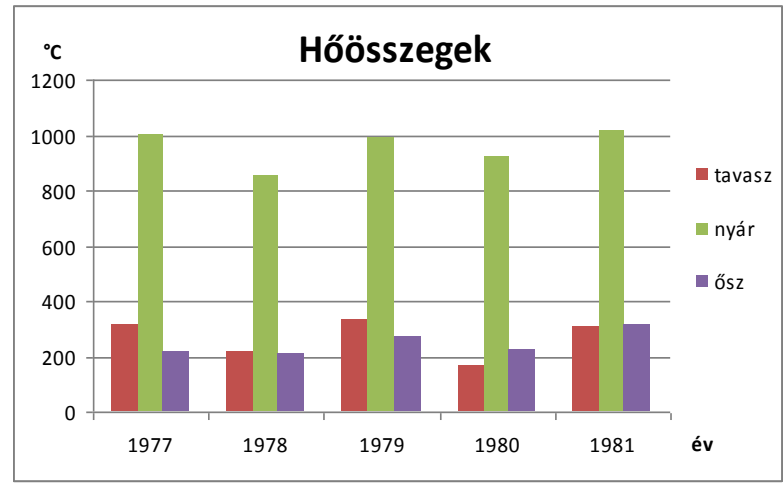

10. ábra: $A+10$ Celsius fok fölötti átlaghőmérséklet-összegek Helvécián a 2000, 2001, 2002, 2003, 2004 évek vegetációs periódusai alatt, évszakonként (tavasz: márc.-máj.; nyár: jún.-aug.; ösz: szept.-nov.)

Az öt év csapadékviszonyait tekintve a leghüvösebb nyár során, azaz 2000-ben esett a legkevesebb csapadék $(284,51 \mathrm{~mm})$ Bács-Kiskun megye területén. Ennek nagyobb része (221,36 $\mathrm{mm}$ ) a téli és a tavaszi hónapokban hullott, míg nyáron összesen $35 \mathrm{~mm}$-t mértek. 2001 viszont a második legcsapadékosabb év lett, 572,54 mm-rel, majd ismét visszaesett a csapadékmennyiség, 2002-ben már csak 353,69 mm volt. 2003-ban az éves csapadék mennyisége ebben a megyében 460,63 mm volt, 2004-ben pedig 583,6 mm-rel a legmagasabb értéket mérték az öt év tekintetében (11. ábra).

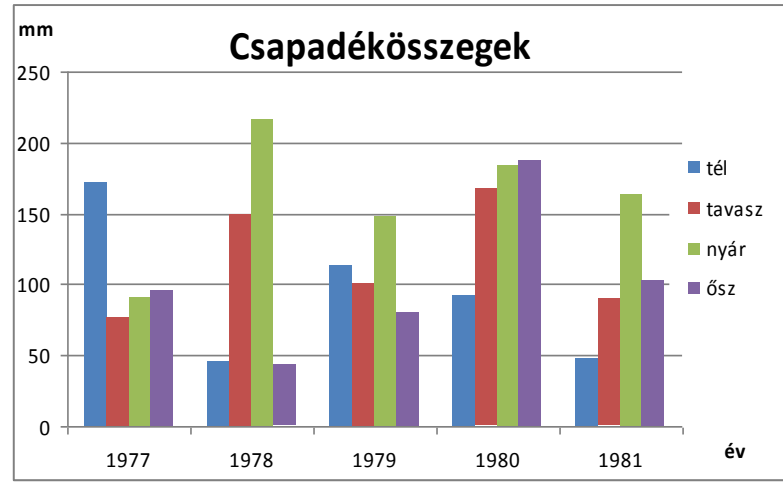

11. ábra: Éves csapadékösszegek évszakos felbontásban Helvécián 2000 és 2004 között (tél: dec.-febr.; tavasz: márc.-máj.; nyár: jún.-aug.; ősz: szept.-nov.)

A tenyészidőszakszámítást többféle módon végezhetjük, erre a 3.5 fejezetben még visszatérünk. Itt most a szőlészetben alkalmazott interpolációs módszerrel meghatározott tenyészidőszak számítási módszer (Csepregi, 1997) eredményeit közlöm. A tenyészidőszakokat összehasonlítva megállapítható, hogy Helvécián a két leghosszabb tenyészidővel a 2000-es (233 nap) és 2001-es évek (236 nap) rendelkeznek (11. táblázat, 12. ábra). Ez jóval több, mint a Magyarországon sokévi átlagban mért 185-200 nap. A 2002-es év 198 napos tenyészidőszaka átlagosnak tekinthető. A 2003-as év 178 napos értéke hazai viszonylatban már átlagon alulinak 
mondható. A 2004-es év ismét átlagon felüli, 215 napos tenyészidővel. Az öt év átlaga 212 nap, ami a hosszú tenyészidejü kései fajták igényeit is kielégítik (Bényei et al., 1999).

11. táblázat: A tenyészidőszakok hossza napokban, valamint a tenyészidőszakok kezdete és vége Helvécián 2000-2004-ig

\begin{tabular}{|c|c|c|c|c|c|}
\hline év & hossza (nap) & kezdete & Julianus nap & vége & Julianus nap \\
\hline 2000 & 233 & 2000. március 31. & 91 & 2000. november 14. & 324 \\
\hline 2001 & 236 & 2001. április 10. & 100 & 2001. december 01. & 336 \\
\hline 2002 & 198 & 2002. április 05. & 95 & 2002. október 20. & 293 \\
\hline 2003 & 178 & 2003. április 16. & 106 & 2003. október 10. & 284 \\
\hline 2004 & 215 & 2004. április 07. & 98 & 2004. november 03. & 313 \\
\hline
\end{tabular}

A 12. ábraán a tenyészidőszakok egymáshoz viszonytott hosszúságait ábrázoltam. Láthatóak a kezdő és végső időpontok változásaiból fakadó eltérések is.

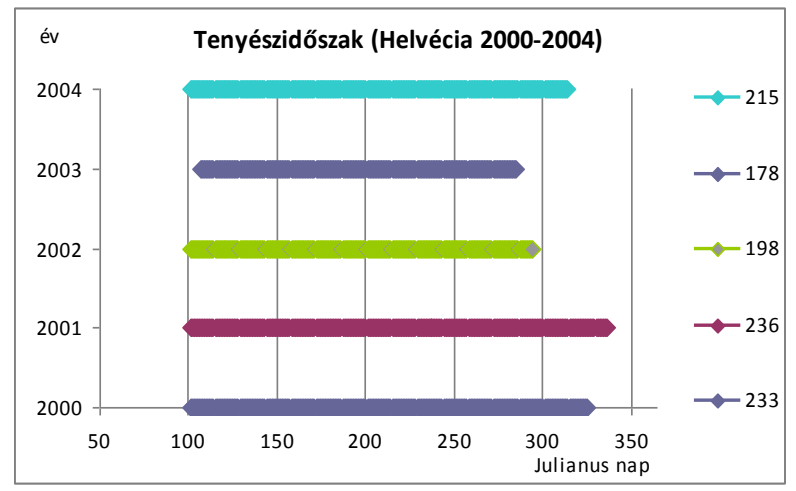

12. ábra: A tenyészidőszakok hossza Helvécián 2000-2004-ig interpolációs módszerrel számítva Kecskemét1976 öszétöl 2003 öszéig

A kecskeméti fenológiai adatok 1977-től 2003-ig terjednek. Ezeket az éveket is megvizsgáltuk meteorológiai szempontból, amihez a kecskeméti kutatóintézet mérőállomásának adatait használtuk fel.

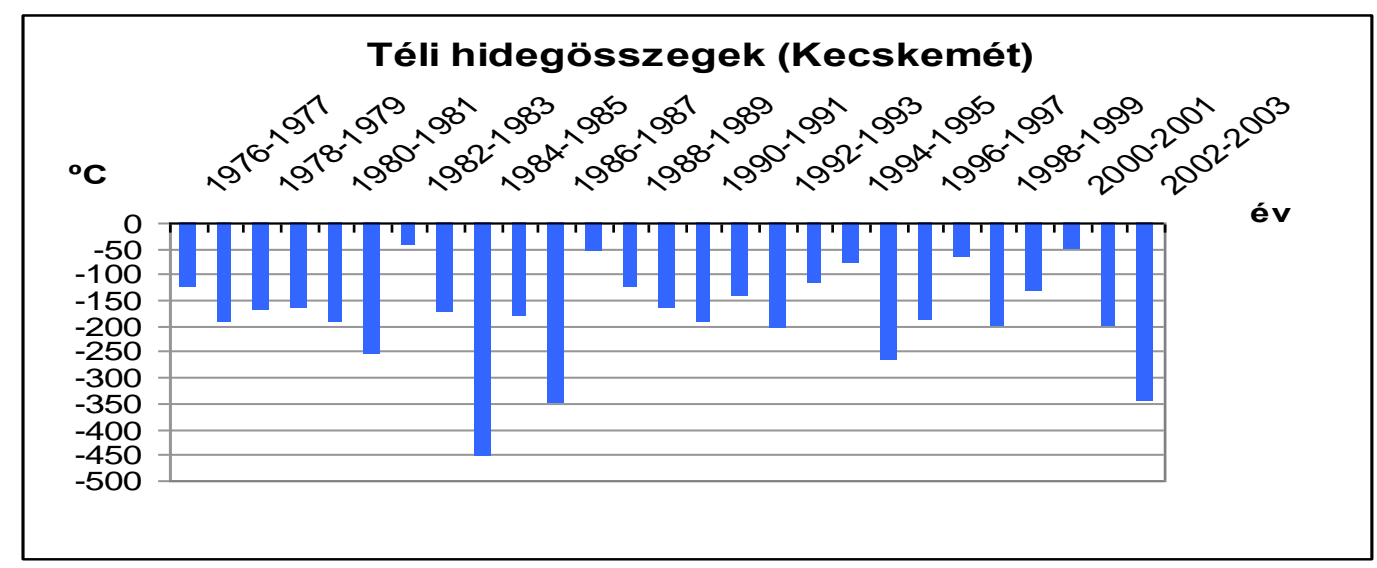

13. ábra: A fagypont alatti átlaghőmérséklet-összegek Kecskeméten 1976 őszétől 2003 tavaszáig éves felbontásban 

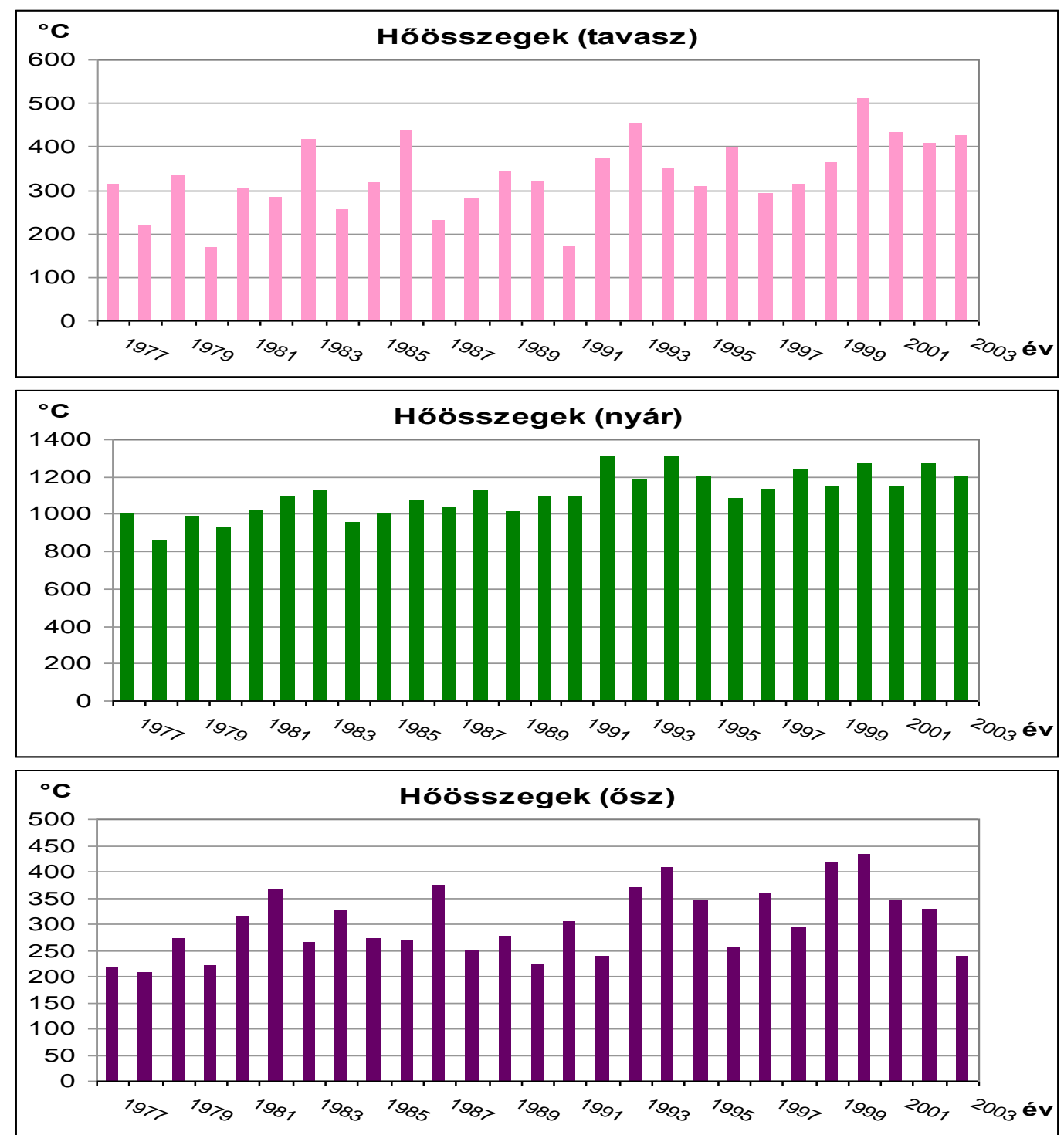

14. ábra: Kecskeméten mért höösszeg adatok 1977 és 2003 között évszakos felbontásban

A 13. ábra mutatja, hogy a feldolgozott időszak alatt a leghidegebb tél 1984-1985 telén köszöntött be, $-452,7{ }^{\circ} \mathrm{C}$ hidegösszeggel. Ezt követte az 1986-1987-es tél -349,6 ${ }^{\circ} \mathrm{C}$, illetve 2002-2003 telén $348,1{ }^{\circ} \mathrm{C}$ hidegösszeggel. A legenyhébb telek 1982-1983, 1987-1988 és 20002001 telén voltak, amely teleken összesen $50^{\circ} \mathrm{C}$ körüli hidegösszeg gyült össze.

Ha a hőösszeg adatok grafikonjára pillantunk (14. ábra), jól látható, hogy 1992-től a hőösszeg értékek megemelkedtek, s ez egybevág a nemzetközi tapasztalatokkal is, miszerint az átlaghőmérséklet-emelkedés az 1990-es évektől jól észrevehető. A legmelegebb nyarakon 1992-ben, 1994-ben, 1998-ban, 2000-ben és 2002-ben több mint $1200{ }^{\circ} \mathrm{C}$ hőösszeg gyült össze június 1-je és augusztus 31-e között. A leghủvösebb nyár 1978 nyarán volt, amikor csupán 857,9 ${ }^{\circ} \mathrm{C}$ hőösszeg gyült össze.

A hőösszegek emelkedésének tendenciája nemcsak a nyári, hanem a tavaszi és az őszi időszakban is megfigyelhető a 70-es évek végétől az ezredfordulóig, és ezek a tendenciák szignifikánsak (tavasz: $p<0,05$; nyár: $p<0,001$; ősz: $p<0,05$ ). 
A kecskeméti éves csapadékmennyiség összegei láthatóak a 15. ábrán 1977 és 2003 között. Magyarországon az éves csapadékmennyiség sokéves átlagban 500-800 mm (Bényei et al., 1999). A 27 év alatt összesen négy évben (1980, 1995, 1998 és 1999) esett 600 mm feletti csapadékmennyiség. 500 és 600 mm között hullott csapadék 6 év során, 1985-ben, 1987-ben, 1989-ben, 1991-ben, 1996-ban és 2001-ben. A fennmaradó 16 évben átlag alatti csapadékmennyiséget mértek. A legaszályosabb év 2000-ben volt, amikor összesen 219 mm-t csapadék esett egész évben.

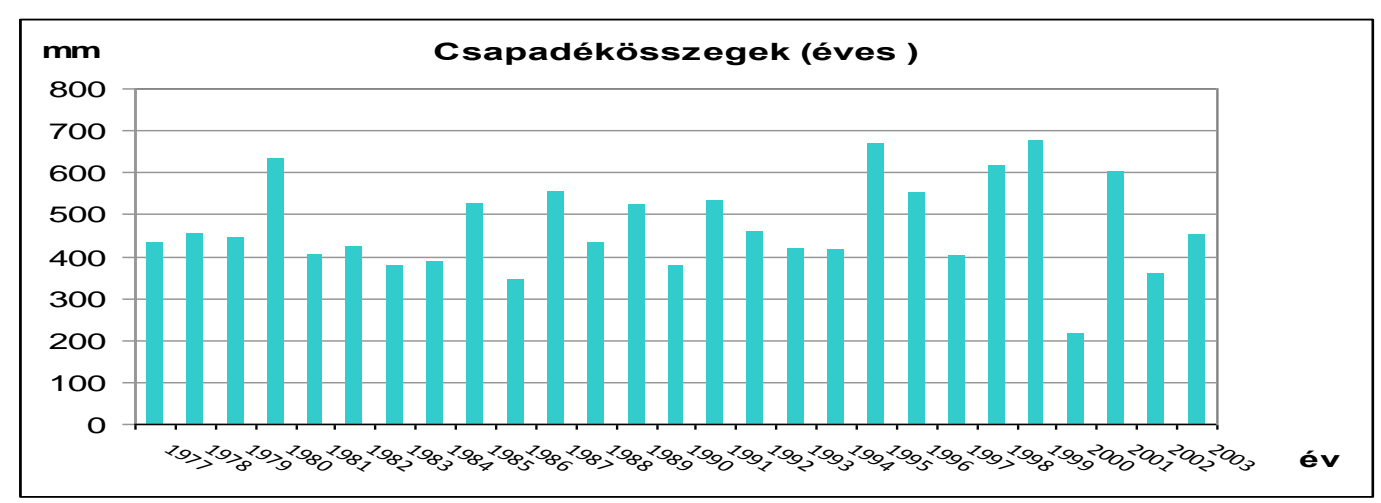

15. ábra: Kecskeméten mért éves csapadékmennyiségek 1977 és 2003 között

A csapadékmennyiségek éves összegét évszakos felbontásban is ábrázoltam, mely a 16. ábrán látható. Általánosságban elmondható, hogy az egyes évek adatait nézve a csapadékmennyiség szempontjából nem történt szignifikáns változás a vizsgált 27 év alatt sem éves, sem évszakos szinten, a szignifikancia szint minden esetben 0,1 felett van.

Meghatároztam a tenyészidőszakok hosszait a vizsgált 27 évben, kétféle módszerrel. Mivel a statisztikai összehasonlítás biztosabbnak tekinti az interpolációs tenyészidőszak számítási módszert a szőlő esetében, így csak ennek az eredményeit közlöm (12. táblázat). A módszerek leírását a 3.6 fejezetben közlöm.

A szőlő tenyészideje Magyarországon sokéves átlagban 185-200 nap között alakul (Bényei et al., 1999). Az átlagos tenyészidőszak hosszúság a kecskeméti termőhelyen 27 év átlagában 200 nap, interpolációs módszerrel számolva. A legrövidebb tenyészidőszakok 1977-ben (178 nap), 1982-ben (169 nap) és 1998-ban (160 nap) voltak. A korai érésü fajták termesztésének alapfeltétele a 150 napos periódus, a kései érésű fajták 185-200 napos vegetációs periódust igényelnek (Bényei et al., 1999). 11 évben átlagon felüli, azaz 200 nap fölött volt a tenyészidőszak napjainak száma. A leghosszabb tenyészidővel 267 nappal a 2000-es év rendelkezett, amely évben a számítások szerint március 27-től december 21-ig tartott a vegetációs periódus. 

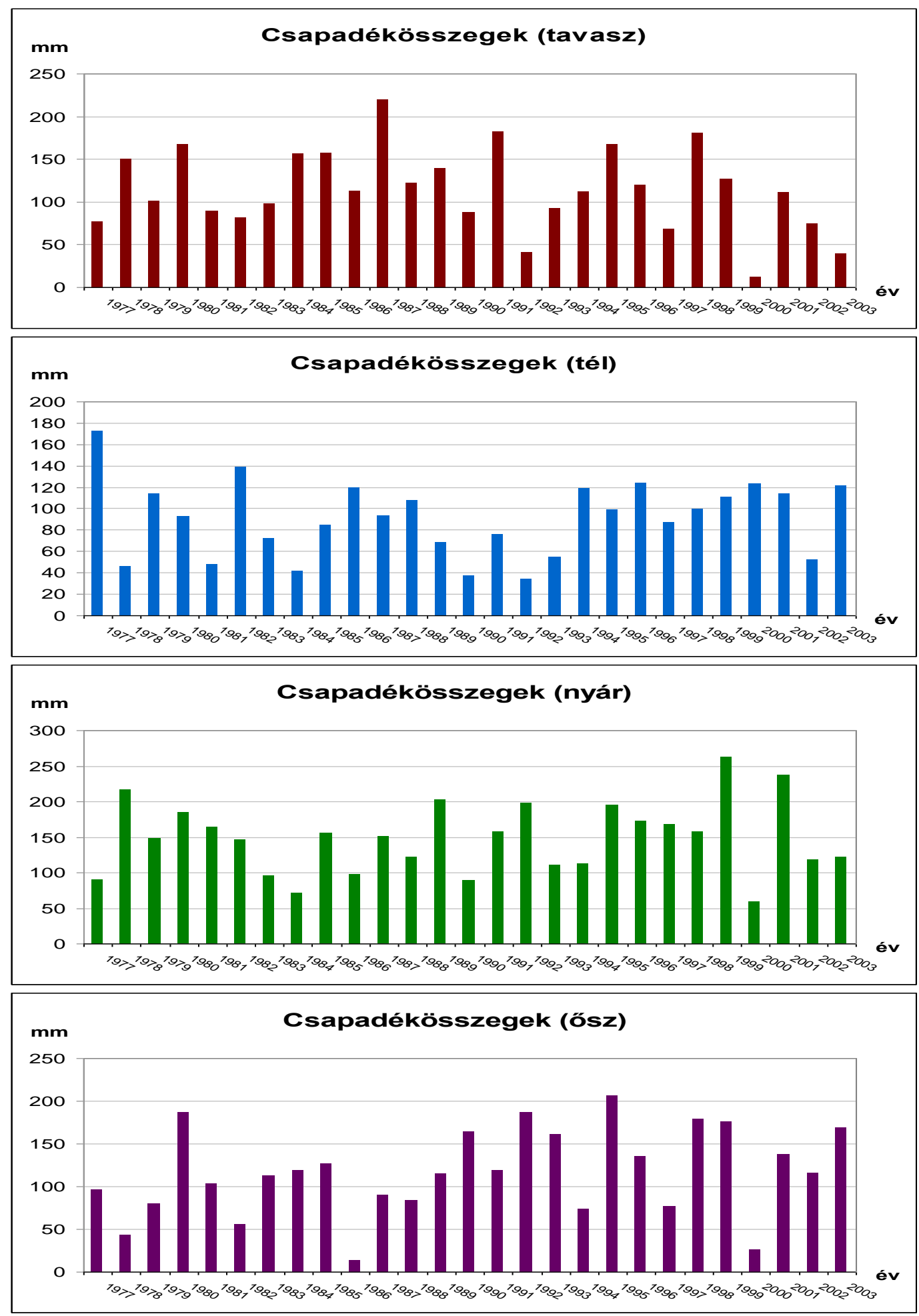

16. ábra: A csapadékmennyiségek évszakos felbontásban Kecskeméten 
12. táblázat: A tenyészidőszakok hossza napokban, valamint a tenyészidőszakok kezdete és vége Kecskeméten 1977-2003-ig

\begin{tabular}{|c|c|c|c|c|c|}
\hline év & hossza (nap) & kezdete & Julianus nap & vége & Julianus nap \\
\hline 1977 & 178 & 1977. április 19. & 109 & 1977. november 05. & 287 \\
\hline 1978 & 186 & 1978. április 10. & 100 & 1978. október 23. & 286 \\
\hline 1979 & 183 & 1979. április 12. & 102 & 1979. október 12. & 285 \\
\hline 1980 & 184 & 1980. április 23. & 114 & 1980. október 24. & 298 \\
\hline 1981 & 208 & 1981. április 04. & 94 & 1981. október 29. & 302 \\
\hline 1982 & 169 & 1982. április 27. & 117 & 1982. október 23. & 286 \\
\hline 1983 & 203 & 1983. március 29. & 88 & 1983. október 18. & 291 \\
\hline 1984 & 205 & 1984. április 09. & 100 & 1984. október 31. & 305 \\
\hline 1985 & 193 & 1985. április 07. & 97 & 1985. október 17. & 290 \\
\hline 1986 & 197 & 1986. április 04. & 94 & 1986. október 18. & 291 \\
\hline 1987 & 195 & 1987. április 11. & 101 & 1987. szeptember 23. & 296 \\
\hline 1988 & 187 & 1988. április 12. & 103 & 1988. október 16. & 290 \\
\hline 1989 & 213 & 1989. március 25. & 84 & 1989. október 24. & 297 \\
\hline 1990 & 208 & 1990. március 28. & 87 & 1990. október 22. & 295 \\
\hline 1991 & 180 & 1991. április 18. & 108 & 1991. október 15. & 288 \\
\hline 1992 & 197 & 1992. április 01. & 92 & 1992. október 15. & 289 \\
\hline 1993 & 191 & 1993. április 07. & 97 & 1993. november 06. & 288 \\
\hline 1994 & 208 & 1994. március 23. & 82 & 1994. október 17. & 290 \\
\hline 1995 & 238 & 1995. április 05. & 95 & 1995. december 01. & 333 \\
\hline 1996 & 237 & 1996. április 08. & 99 & 1996. december 03. & 336 \\
\hline 1997 & 191 & 1997. április 08. & 98 & 1997. október 16. & 289 \\
\hline 1998 & 160 & 1998. május 11. & 131 & 1998. november 14. & 291 \\
\hline 1999 & 204 & 1999. április 03. & 93 & 1999. október 24. & 297 \\
\hline 2000 & 267 & 2000. március 27. & 87 & 2000. december 21. & 354 \\
\hline 2001 & 249 & 2001. március 25. & 84 & 2001. december 01. & 333 \\
\hline 2002 & 200 & 2002. március 27. & 86 & 2002. október 23. & 286 \\
\hline 2003 & 186 & 2003. április 07. & 97 & 2003. október 10. & 283 \\
\hline
\end{tabular}

A 17. ábra a kecskeméti termőhely tenyészidőszakainak hosszait mutatja egymáshoz viszonyítva, a kezdő és záró időpontok eltolódását is láttatva a különböző években. 


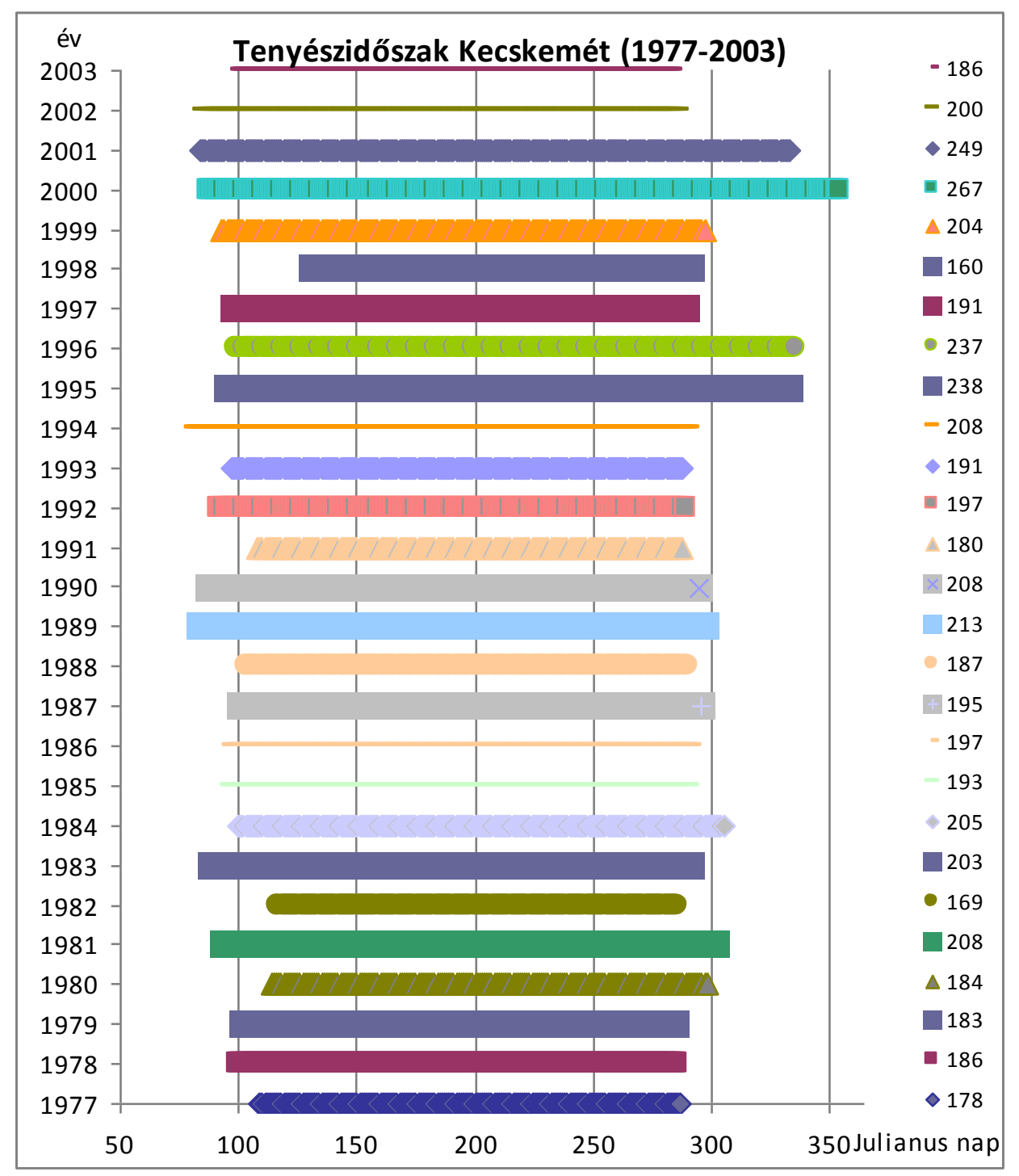

17. ábra: A tenyészidőszakok hossza az interpolációs módszerrel számítva

\subsection{A vizsgálat anyaga}

\section{Helvécia}

Első tanulmányunkat a helvéciai adatokból 5 fehérborszőlö-fajtára (Chardonnay, Rajnai rizling, Hárslevelü, Pinot blanc és Szürkebarát), valamint ezek klónjaira végeztük. Részletes összesítésük a 13. táblázatban látható.

\section{Kecskemét}

A hosszabb időtartamú kecskeméti adatsorokból a Kékfrankos, a Hárslevelü, a Szürkebarát, a Rajnai rizling és a Generosa fajtákat választottuk ki (13. táblázat).

Rendszertani szempontból a hét fajta közül öt a nyugati változatcsoporthoz (convarietas occidentalis) tartozik, a Hárslevelü két klónja egyedül képviseli a pontuszi változatcsoportot (convarietas pontica), hetedik fajta pedig a Kecskemét-Miklóstelepen nemesített intraspecifikus hibrid, a Generosa. 
13. táblázat: A vizsgálatba bevont fajták és klónjaik összefoglaló táblázata

\begin{tabular}{|c|c|c|c|c|c|c|}
\hline Fajta & Klón (kód) & Eredet & $\begin{array}{c}\text { Érési } \\
\text { idö }\end{array}$ & $\begin{array}{c}\text { Felvételezés } \\
\text { helye }\end{array}$ & $\begin{array}{c}\text { Felvételezés } \\
\text { ideje }\end{array}$ & Hiányzó évek \\
\hline \multirow[t]{3}{*}{ Chardonnay } & & $\begin{array}{c}\text { convar. } \\
\text { occidentalis }\end{array}$ & korai & Helvécia & $2000-2004$ & - \\
\hline & Chardonnay 75 & $\begin{array}{c}\text { convar. } \\
\text { occidentalis }\end{array}$ & korai & Helvécia & $2000-2004$ & - \\
\hline & Chardonnay 96 & $\begin{array}{c}\text { convar. } \\
\text { occidentalis }\end{array}$ & korai & Helvécia & $2000-2004$ & - \\
\hline \multirow[t]{3}{*}{ Szürkebarát } & & $\begin{array}{c}\text { convar. } \\
\text { occidentalis }\end{array}$ & korai & Kecskemét & $1977-2003$ & $\begin{array}{c}1980,1987 \\
1988,1993- \\
1997\end{array}$ \\
\hline & Szürkebarát 34 & $\begin{array}{c}\text { convar. } \\
\text { occidentalis }\end{array}$ & korai & Helvécia & $2000-2004$ & - \\
\hline & Szürkebarát 52 & $\begin{array}{c}\text { convar. } \\
\text { occidentalis }\end{array}$ & korai & Helvécia & $2000-2004$ & - \\
\hline \multirow[t]{4}{*}{ Kékfrankos } & & & közepes & Kecskemét & $1977-2003$ & $\begin{array}{c}1980,1987, \\
1993-1997\end{array}$ \\
\hline & Pinot blanc 54 & $\begin{array}{c}\text { convar. } \\
\text { occidentalis }\end{array}$ & közepes & Helvécia & $2000-2004$ & - \\
\hline & Pinot blanc 55 & $\begin{array}{c}\text { convar. } \\
\text { occidentalis }\end{array}$ & közepes & Helvécia & $2000-2004$ & - \\
\hline & $\begin{array}{c}\text { Pinot blanc } \\
\text { D55 }\end{array}$ & $\begin{array}{c}\text { convar. } \\
\text { occidentalis }\end{array}$ & közepes & Helvécia & $2000-2004$ & - \\
\hline Generosa & & $\begin{array}{c}\text { intraspecifikus } \\
\text { hibrid }\end{array}$ & kései & Kecskemét & $1977-2003$ & $\begin{array}{c}1980,1987, \\
1988,1992- \\
1997\end{array}$ \\
\hline \multirow[t]{7}{*}{ Hárslevelü } & & $\begin{array}{l}\text { convar. } \\
\text { pontica }\end{array}$ & kései & Kecskemét & $1977-2003$ & $\begin{array}{c}1980,1987, \\
1993-1997\end{array}$ \\
\hline & $\begin{array}{l}\text { Hárslevelü } \\
\text { P.41 }\end{array}$ & $\begin{array}{l}\text { convar. } \\
\text { pontica }\end{array}$ & kései & Helvécia & $2000-2004$ & - \\
\hline & Hárslevelü K.9 & $\begin{array}{l}\text { convar. } \\
\text { pontica }\end{array}$ & kései & Helvécia & $2000-2004$ & - \\
\hline & $\begin{array}{c}\text { Rajnai rizling } \\
239\end{array}$ & $\begin{array}{c}\text { convar. } \\
\text { occidentalis }\end{array}$ & kései & Helvécia & $2000-2004$ & - \\
\hline & $\begin{array}{c}\text { Rajnai rizling } \\
378\end{array}$ & $\begin{array}{c}\text { convar. } \\
\text { occidentalis }\end{array}$ & kései & Helvécia & $2000-2004$ & - \\
\hline & $\begin{array}{c}\text { Rajnai rizling } \\
391 \\
\end{array}$ & $\begin{array}{c}\text { convar. } \\
\text { occidentalis }\end{array}$ & kései & Helvécia & $2000-2004$ & - \\
\hline & $\begin{array}{c}\text { Rajnai rizling } \\
49\end{array}$ & $\begin{array}{c}\text { convar. } \\
\text { occidentalis }\end{array}$ & kései & Helvécia & $2000-2004$ & - \\
\hline $\begin{array}{l}\text { Rajnai } \\
\text { rizling }\end{array}$ & & $\begin{array}{c}\text { convar. } \\
\text { occidentalis }\end{array}$ & kései & Kecskemét & $1977-2003$ & $\begin{array}{c}1978-1980, \\
1993-1997\end{array}$ \\
\hline
\end{tabular}

\subsubsection{A vizsgált fajták jellemzése}

\section{Öshonos fajták}

Hárslevelü: egyesek itáliai, mások szláv nyelvterületről származónak vélik, de a legnagyobb valószínüséggel természetes beporzással és termékenyüléssel létrejövő magyar fajta. $\mathrm{Az}$ elfogadott rendszerezés szerint convarietas pontica, subconvarietas balcanica, provarietas microcarpa, subprovarietas zemplenica. Széles körben ismert és termesztett fajta, föként TokajHegyalján, az Egri borvidéken, Mátraalján, a Villányi borvidék Siklósi körzetében termesztik. Tőkéje erős növekedésü. Termése egyedülállóan nagy, hossza elérheti a 300-500 mm-t, fürtátlagtömege 180-200 g körül alakul. Bogyója kicsi, gömbölyü, zöldessárga színű. Hosszú tenyészidejű, október elején, közepén érő fajta. Viszonylagos fagytürőképessége közepes vagy 
az alatti. A szárazságra érzékeny, jó vízgazdálkodású területekre kell ültetni. Rothadásra érzékeny, mely kedvező évjáratokban nemes rothadásba megy át, aszúsodik (Bényei és Lőrincz, 2005). Bora jól felismerhető, fajtajelleges, hársméz illatú, finom savtartalmú, testes. Aszúbor készítésére alkalmas (Bisztray et al., 2011, szerk. Hajdu). Vizsgált klónjai: Hárslevelü P.41, Hárslevelü K.9.

\section{Honositott fajták}

Chardonnay: francia eredetü fajta, minőségi fehérborszőlő-fajta. A világ minden borszőlőtermesztő országában ismerik, termesztik, így világfajtának tekinthető (Csepregi, 1997). A természetes rendszer szerint convarietas occidentalis, subconvarietas. gallica, provarietas. microcarpa, subprovarietas „Noirien” eredetü (Bényei és Lőrincz, 2005). A legújabb DNS analízis eredménye szerint a Pinot noir $\times$ Heunisch weiss spontán keresztezése által jött létre (Sefc et al., 1997, Bisztray et al., 2011, szerk. Hajdu, 2011). Korai érésű, szeptember közepétől szüretelhető. Erős növekedésü, közepes termőképességü, fagytürő képessége a közepesnél valamivel jobb, a szárazabb viszonyokat is elviseli, jó adaptációs képességekkel rendelkezik. Rothadásra hajlamos. Termése kicsi, hengeres, középtömött fürtü, jellegzetes ízü bogyókkal. Bora fajtajelleges, különleges zamatú, testes, széleskörüen felhasználható. Kitűnő pezsgőalap lehet, de kiváló minőségi bor, sőt különleges minőségü, akár természetes csemegebor is készíthető belőle (Bényei és Lőrincz, 2005). Vizsgált klónjai: Chardonnay 75 és Chardonnay 96.

Pinot blanc: Franciaországból származik, ahol régóta termesztik. A természetes fajtarendszerezés szerint convarieats occidentalis, subconvarietas gallica, provarietas microcarpa, subprovarietas „Noirien”. Franciaországban ismert és elterjedt fajta. Nálunk a két világháború közötti fajtaleírásokban szerepel, de az 1970-es évek közepéig alig telepítették. Nagyobb érdeklődés az elmúlt másfél évtizedben nyilvánult meg iránta. Minőségi fehérborszőlő fajta. Tőkéje középerős növekedésű, fürtje kicsi, hengeres vagy vállas, tömött. Bogyói kicsik, gömbölyüek, vékony, sárgászöld héjúak. Korai tenyészidejű fajta, szeptember első felében érik, de rendszerint a hónap második felében, vagy még később szüretelik. Rügyei termékenyek, jó téltürésüek (Bényei és Lőrincz, 2005). Fürtje gyakran madárkás a virágok hiányos termékenyülése miatt. Bogyói rothadnak. Gombabetegségekre, elsősorban a lisztharmatra érzékeny. Zöldmunka-igényes. Kellemes zamatú, finom illatú fehérbort adó fajta (Bisztray et al., 2011, szerk. Hajdu). Vizsgált klónjai Pinot blanc 54, Pinot blanc 55, Pinot blanc D55.

Rajnai rizling: a Rajna folyó vidékéről származó igen régi fajta, melyet feltételezések szerint már a rómaiak is termesztettek. A természetes rendszerezés szerint a convarietas occidentalis, subconvarietas gallica, provarietas microcarpa-ba sorolható. Németországban uralkodó fajtának számít, főleg Elzászban, de termesztik az összes európai országban. Magyarországon régóta ismert fajta, leromlása miatt háttérbe szorult, de újabb klónok kiválasztásával ismét 
megnövekedett a termesztési területe. Minőségi fehérborszőlö-fajta. Hosszú tenyészidejü, későn, október elején érő fajta. A tiszta vinifera fajták közül a téli hideget legjobban türő fajta, ezért az alföldi borvidékek takarás nélküli szőlőtermesztésének megbecsült fajtája (Bényei és Lőrincz, 2005). Virágzás idején azonban a lehülésre érzékeny. Hidegben kedvezőtlen a virágok termékenyülése, a fürtök gyakran madárkásak. Aszályra igen érzékeny. Termése kisméretü, hengeres, tömött fürtü, sárgászöld bogyókkal. Lisztharmatra érzékeny. Bora szőlővirág emlékeztető, finom illatú és jellegzetes zamatú. Savai finomak, elegánsak. Jó évjáratokban nagy minőségü fehérbort ad (Bisztray et al., 2011, szerk. Hajdu). A viszgálatunkban szereplő klónjai: Rajnai rizling 239, Rajnai rizling 378, Rajnai rizling 391, Rajnai rizling 49.

Szürkebarát: nagyon régi, francia eredetü fajta. A természetes fajtarendszerezés szerint convarieats occidentalis, subconvarietas gallica, provarietas microcarpa, subprovarietas „Noirien”. Concultát alkotnak a Pinot blanc-nal, a Pinot noir-ral (Bényei és Lőrincz, 2005). Világfajta, mivel minden környezetben határozott karakterü, fajtajelleges bort ad. Értéke mindenekelőtt finom savtartalmának megtartásában rejlik (Csepregi, 1997). Magyarországon a Balatonfelvidéken és a Badacsonyi borvidéken vált híressé. Az elmúlt néhány évtizedben az ország más borvidékeire is telepítették és kiváló termést szüretelnek róla. Rövid tenyészidejü fajta, szeptember első felében érik (Bényei és Lőrincz, 2005). Termése kis, hengeres, nagyon tömött fürtü, a bogyók héja kékespiros, pontozott, hamvas. Jó fagytürő képességü, bogyói rothadásra kissé érzékenyek. Bora enyhén narancsos színü, illatos, jellegzetes ízü, tüzes, rendkívül finom savú fehérbor. Magas cukortartalmú termésből különleges minőségü bor készíthető (Bisztray et al., 2011, szerk. Hajdu). Vizsgált klónjai: Szürkebarát 34, Szürkebarát 52.

Kékfrankos: eredete bizonytalan, de Németh (1970) szerint a convarietas orientalis subconvarietas caspica változat alcsoportba tartozik. Leginkább Magyarországon terjedt el. Az összes vörösbort termelő vidéken megtalálható, sőt a legtöbb helyen meghatározó jelentőségü fajta. Első a vörösborszőlők területi rangsorában. Számos értékes tulajdonsága miatt a jövőben is ígéretes fajta marad (Bényei és Lőrincz, 2005). Kecskeméti vizsgálatok alapján $-19{ }^{\circ} \mathrm{C}-\mathrm{ig}$ télálló (Hajdu és Borbásné Saskői, 2009). Erős növekedésű, viszonylag jó termőképességü, értékes fajta. Rendszerint megbízhatóan terem, s a legrosszabb évjáratokban is elfogadható minőséget ad (Bényei és Lőrincz, 2005). A középérésű fajta. Október elején érik. Rügyei jó tél- és fagytürők. A szárazságot is jól türi. Tápanyagban gazdag, jó vízgazdálkodású területen jobb minőségű termést ad. Bora fajtajelleges, kellemes zamatú, testes, fanyar, kissé savas (Bisztray et al., 2011, szerk. Hajdu). Színanyag tartalma még gyengébb évjáratokban is kielégítö. Különösen neves a Soproni Kékfrankos, de alkotórészét, vázát képezi a Bikavérnek is (Bényei és Lőrincz, 2005). 


\section{Eurázsiai intraspecifikus fajták}

Generosa: a fajtát Hajdu Edit és munkatársai emelték ki és értékelték abból a magoncpopulációból, amelyet Bíró Károly az Ezerjó és a Piros tramini keresztezéséből állított elő 1951-ben. Fajtahibrid. Tőkéje erős növekedésü, jó termőképességü. Fürtje középnagy, bogyói húspirosak, húsuk lédús, színtelen. Szeptember végén, október elején érő fajta. Fitotechnikája egyszerü, könnyü metszeni, kevés zöldmunkát igényel (Bényei és Lőrincz, 2005). Homokos és kötött talajon egyrán jól terem (Bisztray et al., 2011, szerk. Hajdu). Kiemelkedően jó a fagy- és téltürése, nem vagy alig rothad. Peronoszpórára igen, a lisztharmatra kevésbé fogékony (Bényei és Lőrincz, 2005). Bora Tramini jellegü, szőlvirág illatú,, savai Ezerjóéhoz hasonlóak, harmonikus fehérbor (Bisztray et al., 2011, szerk. Hajdu).

\subsection{Fenológiai adatok}

Vizsgálatainkhoz a Helvécián és Kecskeméten felvételezett rügyfakadási és fővirágzási időpontokat használtuk fel. A rügyfakadás kezdő időpontjai mindkét termőhelyen akkor lettek feljegyezve, amikor az állomány egyedeinek 50 \%-nál a becslések alapján megtörtént a rügyfakadás. A szőlő virágzásakor a virágnyílást akkor tekintjük megkezdettnek, amikor a virágok 4-5 \%-a kinyílt. A tömeges virágzás (fővirágzás) időpontját pedig arra a napra határozták meg, amikor az adott fajtánál a virágok 60-70 \%-a kinyílt.

A rügyfakadási és fővirágzási időpontok Helvécián 2000 és 2004 között lettek feljegyezve, ami egy teljes öt éves adatsort jelent mind az öt fajta esetében. KecskemétKatonatelepen 1977 és 2003 között felvételezett adatokból összesen 20 év adatsora áll rendelkezésünkre 1977 és 1979, 1981 és 1986, 1988 és 1992, valamint 1998 és 2003 között a Kékfrankos és a Hárslevelü fajták esetében. Ez egy 27 éves időintervallumot fed le az 1980-as, 1987-es és az 1993-tól 1997-ig tartó hiányzó évekkel. A Szürkebarát esetében 19 évet tudtunk vizsgálni, ahol az előző hiányzó évekhez még hozzáadódott az 1988-as év is. A Rajnai rizling és a Generosa esetében 18 év rügyfakadási és fővirágzási adat állt rendelkezésünkre, de úgy gondoltuk ennyi év adatsora elegendő lesz a modellezéses vizsgálatokhoz. A hiányzó éveket a mindegyik fajta esetében a 13. foglalja össze.

\subsection{Tenyészidő számítási módszerek}

Az optimum törvénye szerint a hőmérsékletnek a növényre gyakorolt hatását fenológiai fázisonként Gauss-, vagy ahhoz hasonló görbével jellemezhetjük. A görbe csúcsa a növényre optimálisan ható hőmérséklet felett helyezkedik el, a görbe alacsony értékei pedig a növény fejlődését fékező vagy a káros hőmérsékletek felett fekszenek. Eszerint a höösszegek módszere az ellentétes biológiai hatású értékek valamely módon definiált összegzése. A különböző hőösszeg-modellek legfőbb jellemzője éppen az, hogy milyen módon definiálják a hatásgörbét, 
valamint az összegezést (Chuine, 2000; Chuine et al., 2003).

A hőösszegeket kezdetben a meteorológiai $0^{\circ} \mathrm{C}$-tól kiindulva számították. Újabban az ún. hatásos hőösszeggel jellemzik a vegetációs lehetőségeket. Eszerint a hőösszeget úgy számoljuk ki, hogy a vegetációs időszak középhőmérsékletét megszorozzuk a vegetációs idő napjainak számával (Kozma, 1991; Bényei et al., 1999).

A hőösszegek kiszámításának másik módja az, hogy az előbbi módon kiszámított hőösszegből levonjuk a vegetációs idő alatti a $+10^{\circ} \mathrm{C}$-on (biológiai $0^{\circ}$-on) aluli hőmérsékletek összegét, tekintettel arra, hogy az alacsony hőmérséklet nem segíti, illetve gátolja a vegetációt. Ezt hatásos hőösszegnek nevezik (Kozma, 1991).

A vegetációs időt napokban megadva nemzetközileg a tavaszi napi $+10^{\circ} \mathrm{C}$-os (biológiai $0^{\circ}$ ) középhőmérséklet beállásától az őszi $+10^{\circ} \mathrm{C}$ középhőmérsékletű napok megszünéséig számítják. Hogy a fenti fogalmakat pontosan miként (napi, havi hőmérsékletekből) definiálják, attól függően a hőösszegszámítási módszerek, illetve a tenyészidőszak vagy vegetációs periódus hosszának meghatározása is különbözhet. Egy, a hőösszegszámítás további módosításával kapott módszer, melyet a szőlőtermesztésben gyakran alkalmaznak, az ún. interpolációs módszer (Bényei et al., 1999).

A tenyészidőszak-számításokat minden évre elvégeztem kétféle módszerrel, a két helyszínen. Elöször a 2000 és 2004 közötti időtartamra számoltam ki, a megyei átlaghőmérséklettel, majd 1977 és 2003 között a kecskeméti mérésekkel.

I. módszer: a tenyészidőszak kezdete az az első nap, amikor az átlaghőmérséklet $10{ }^{\circ} \mathrm{C}$ felett van, és ami után már nem lesz $10{ }^{\circ} \mathrm{C}$ alatt őszig. A tenyészidőszak vége az a nap, amikor utoljára van megszakítás nélkül $10{ }^{\circ} \mathrm{C}$ felett az átlaghőmérséklet (Kozma, 1991).

II. módszer (interpolációs módszer): A tenyészidőszak első napját úgy számoljuk ki, hogy vesszük a március és az április hónapok középhőmérsékleteit, majd az áprilisi középhőmérsékletből kivonjuk a márciusi középhőmérséklet értékét és osztjuk 31-gyel. Ekkor megkapjuk a $\mathrm{d}_{1}$ értéket, amit $\mathrm{n}_{1}$-szer hozzáadunk a márciusi átlaghömérséklethez, míg az először át nem lépi a $10^{\circ} \mathrm{C}$ fokos értéket. $\mathrm{Az} \mathrm{n}_{1}$ értéket hozzáadjuk a március 15 -éhez, így megkapjuk a tenyészidőszak első napját (Csepregi, 1997, 14. táblázat). 
14. táblázat: A tenyészidőszak kezdetének, végének és hosszának számítása az interpolációs módszerrel (Csepregi, 1997)

\begin{tabular}{|c|c|}
\hline $\begin{array}{c}\text { Vegetációs időszak kezdetének } V_{1}[\text { dátum }] \\
\text { számítása }\end{array}$ & $\begin{array}{c}\text { Vegetációs időszak végének } V_{2}[\text { dátum }] \\
\text { számítása }\end{array}$ \\
\hline$d_{1}\left[{ }^{\circ} C\right]=\frac{T_{\text {attlapr. }}-T_{\text {atl.márc. }}}{31}$ & $d_{2}\left[{ }^{\circ} C\right]=\frac{T_{\text {atl.szept. }}-T_{\text {atl.okt. }}}{30}$ \\
\hline$n_{1}=\min \left\{z: T_{\text {atl.már. }}+z^{*} d_{1}>10^{\circ} C\right\}$ & $n_{2}=\min \left\{z: T_{\text {atl.szept. }}-z^{*} d_{2}<10^{\circ} C\right\}$ \\
\hline$V_{1}[$ dátum $]=m a ́ r c .15 .+n_{1}$ & $V_{2}[$ dátum $]=s z$ ept. $15 .+\left(n_{2}-1\right)$ \\
\hline \multicolumn{2}{|c}{ Tenyészidőszak hossza: $L[$ nap $]=V_{2}-V_{1}+1$} \\
\hline
\end{tabular}

Jelmagyarázat:

$d_{1}\left[{ }^{\circ} \mathrm{C}\right]$ és $d_{2}\left[{ }^{\circ} \mathrm{C}\right]$ az interpolációnál alkalmazott egységnyi hőmérséklet-emelkedés, illetve -csökkenés; $T_{\text {attl.már. } .}, \quad T_{\text {attlappr. }}, \quad T_{\text {attl.seept. }}, \quad T_{\text {attl.okt. }}$ a márciusi, áprilisi, szeptemberi, illetve októberi napi középhőmérsékletek átlagai $\left[{ }^{\circ} \mathrm{C}\right]$;

$n_{1}, n_{2}$ és $z$ természetes számok;

$V_{1}[$ dátum $]$ és $V_{2}[$ dátum $]$ a tenyészidőszak első, illetve utolsó napja;

$L[$ nap $]$ a tenyészidőszak hossza.

A tenyészidőszak utolsó napját az előbbihez hasonló módon számítjuk ki. Ebben az esetben a szeptemberi és az októberi átlaghőmérséklet különbségét vesszük, majd elosztjuk harminccal, mivel ennyi nap telik el szeptembertől októberig. Ekkor megkapjuk a $d_{2}\left[{ }^{\circ} \mathrm{C}\right]$ értéket. Ezt $n_{2}$-ször kivonjuk a szeptemberi középhőmérséklet értékéből, míg a középhőmérséklet először $10^{\circ} \mathrm{C}$ alá nem süllyed. $\mathrm{Az}\left(n_{2}-1\right)$ értékét a végén hozzáadjuk szeptember 15-höz és a kapott dátum a tenyészidőszak utolsó napjának tekinthető.

\subsection{Az alkalmazott fenológiai modellek}

\subsubsection{Egyszerü höösszeg modell a rügyfakadás idejének becslésére}

Munkánk során igyekeztünk olyan egyszerü modellt építeni, amely a lehető legpontosabban közelíti a Helvécián termesztett fehérszőlő fajták közül a 2000-2004-es időszakban fenológiai felvételezésre került 15 fajta rügyfakadásának időpontját. Az adatok szűkösségét figyelembe véve a napi léptékü lineáris modellt választottuk.

A megfigyelt adatokból kiszámoltuk minden fajtára $(i=1,2, \ldots, 15)$ a napi középhőmérsékletnek (a $k$. napit jelöli $T_{k_{-} a t t}$ ) az (alsó) bázishőmérséklet ( $T_{b a ́ z i s}$ ) feletti részét egy adott naptól (kezdőnap: $D_{\text {start }}$ ) kumulálva a megfigyelt rügyfakadásig $\left(D_{i j, m f}^{r f}\right)$, minden évre ( $j=2000,2001, \ldots, 2004)$. 


$$
G D D_{i j}^{r f}=\sum_{k=D_{\text {sart }}}^{D_{i j, m f}^{r f} \max }\left[\left(T_{k_{-} a ́ t l}-T_{b a ́ z i s}\right) ; 0\right]
$$

(GDD - growing degree days) Ezután kiszámoltuk erre az öt évre vonatkozó fajtánkénti átlagot, és ezt az értéket fajtánkénti kritikus höösszegnek neveztük el:

$$
\mathrm{GDD}_{\mathrm{i}, \mathrm{krit}}^{\mathrm{rf}}=\underset{\mathrm{j}}{\operatorname{Át}} \operatorname{lag}\left(\mathrm{GDD}_{\mathrm{i}, \mathrm{j}}^{\mathrm{rf}}\right)
$$

A szőlő (Vitis vinifera L.) esetében széles körben elfogadott (alsó) bázis hőmérséklet $10{ }^{\circ} \mathrm{C}$ (Jones, 2003, Jones et al., 2005). Mivel azonban ez a bázishőmérséklet jó becslés ugyan, ám önkényesnek mondható, modellezésre nem kifejezetten alkalmas, mert sok hibát generál. Ezért úgy döntöttünk, hogy a modellezéskor a bázishőmérsékletet változó paraméternek tekintjük, és azt optimalizálással becsüljük.

A modellt úgy állítottuk fel, hogy ha az egy évben a kezdőnaptól kezdve a bázishőmérséklet feletti hőmérsékleteket kumulálva eléri a fajtánkénti kritikus értéket, akkor arra a fajtára a modell a rügyfakadást jelezze.

A becslés hibáját a modell által becsült napnak $\left(D_{i j, \text { mod }}^{r f}\right)$ a megfigyelt időponttól $\left(D_{i j, m f}^{r f}\right)$ való (napban mért) átlagos eltérés-négyzetösszeg négyzetgyökeként definiáltuk (standard hiba):

$$
R M S E=\sqrt{\frac{1}{N} \sum_{i} \sum_{j}\left(D_{i j, m f}^{r f}-D_{i j, m o d}^{r f}\right)^{2}},
$$

ahol $N$ a fajták és évek szorzatát jelzi.

A bázishőmérsékletre és a kezdőnapra minimalizáltuk a becslés hibáját.

\subsubsection{Egyszerü höösszeg modell a fövirágzás kezdetének idejére}

A növények fejlődése, virágzása az enyhülő időjárás függvényében történik, amelyet a rügyfakadáshoz hasonlóan egy akkumulált hőmérsékleti összeggel definiálhatunk egy bizonyos küszöb eléréséig. Most is, mint az előzőekben, a naponkénti höösszeg-növekedés mértékét $(G D D)$ használjuk, kiszámítva egy bizonyos időszak alatt az átlagos napi hőmérséklet és a küszöb hőmérséklet (alsó bázishőmérséklet) közötti eltérések összegét egy induló naptól, jelen esetben a modell által becsült rügyfakadás-kezdettől.

A bázishőmérséklet becslését a fővirágzás indulási időpontjának becslésekor is optimalizálással külön elvégeztük. A fővirágzás kezdeti időpontjának becsléséhez Gladstones (1992) javaslatára egy felső bázishőmérsékletet is bevezettünk, és akkumuláltuk az alsó bázishőmérséklet feletti, ám a felső bázishőmérsékletet meg nem haladó átlagos napi hőmérsékleteket. Hasonlóan a rügyfakadáshoz, a virágnyílás becslésénél is a napi léptékü lineáris modellt választottuk. 
Egyszerü modellünkkel megbecsülhetjük a vizsgált fajták, illetve klónjaik tömeges virágzásának idejét. A rügyfakadás időpontjának becsléséhez hasonlóan kiszámítottuk minden fajtára $(i=1,2, \ldots, 15)$ és minden évre $(j=2000,2001, \ldots, 2004)$ a megfigyelt adatokból akkumulált napi hatásos ( $T_{\text {alsóbázis }}^{\text {vir }}$ feletti és $T_{\text {felsó bázis }}^{\text {vir }}$ alatti) átlaghőmérsékleteket a modell által elöre jelzett rügyfakadási naptól ( $D_{i j \text {, mod }}^{r f}$ ) a megfigyelt fővirágzás kezdetig ( $D_{i j, m f}^{v i r}$ ).

$$
G D D_{i, j}^{v i r}=\sum_{D_{i, j_{-} \bmod }^{f f}}^{D_{i j, m f}^{v i r}} \max \left[\left(\min \left(T_{k_{-} a \text { att. }}, T_{\text {felsö bázis }}^{v i r}\right)-T_{\text {alsóbázis }}^{v i r}\right) ; 0\right]
$$

Ezután kiszámítottuk az öt évre vonatkozó fajtánkénti átlagot, és ezt az értéket a fővirágzáshoz szükséges fajtánkénti kritikus hőösszegnek neveztük el.

$$
G D D_{i, k r i t}^{v i r}=\operatorname{Átlag}_{j}\left(G D D_{i, j}^{v i r}\right) \text {. }
$$

\subsubsection{Hideghatást is figyelembe vevö fenológiai modell}

A hideghatást is figyelembe vevő hőösszegen alapuló modellünk sokkal kifinomultabb, mint a GDD modell, mivel ez kezeli a mélynyugalmi időszak alatti a növényt érő hőmérsékleti hatásokat is (Chuine, 2000). Ez a modell a (hideg) höösszegek akkumulációját a megelőző év szeptember elsejétől kezdi. Ez esetben a szeptember elsejei választás nem mondható önkényesnek, mert a hideghatást leíró függvény tulajdonságaiból adódóan, a hideghatás ekkor még biztosan nem kezdődik meg, értéke zérus. A szeptember elsejét inkább úgy érdemes tekinteni, mint egy olyan időpontot, amely biztosan megelőzi azt a napot, amikor az akkumulálódás megindul, azaz a függvény értéke zérustól eltérő lesz. A mélynyugalom megtörése mellett a hideg hőösszegeknek van egy rügynövekedést gyorsító hatása is. Ha több hideghatás éri a növényt, kevesebb hőösszeg szükséges a rügyfakadás bekövetkezéséig (Nelson és Lavender, 1979; Cannell és Smith, 1983; Murray et al., 1989; Kramer, 1994b; Chuine et al., 1999). Megkülönböztetünk tehát mélynyugalmi (chilling effect - $\mathrm{CH}$ ) és kényszernyugalmi (forcing effect $-F$ ) hatásokat, majd ezeket dimenzió nélkül definiáljuk:

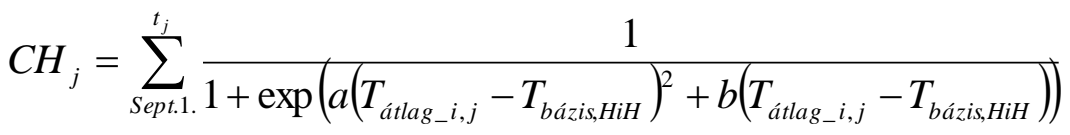

$$
\begin{aligned}
& F_{j}=\sum_{t_{j}}^{\text {rü̈gyakadé }} \frac{1}{1+\exp \left(c\left(T_{\text {atlag_i } i, j}-T_{\text {bäzis,HöH }}\right)\right)}
\end{aligned}
$$

ahol $a, b$, pozitív, $c$ negatív tapasztalati paraméterek, $T_{a \operatorname{tag}{ }_{-} i, j}$ jelenti a napi átlagos hőmérsékletet minden évben $j$ és napon $i$, a $T_{b a ́ z i s, H i H}$ és $T_{b a ́ z i s, H o ̈ H}$ a bázis hőmérsékletek mélynyugalmi és kényszernyugalmi paraméterei, $t_{j}$ az az időpont, amikor a kívánt kritikus mélynyugalmi hideghatás $\left(\mathrm{CH}_{k r i t}\right)$ bekövetkezik egy adott évben $j$. Ennél a pontnál a modell 
jelzi a mélynyugalom végét és a hőösszeg akkumuláció $F_{j}$ elindul. A rügyfakadást akkor jelzi a modell, amikor a szükséges hatásos höösszeg $G D D_{u_{-} k r i t}$ összegyülik.

A hideghatás és a kényszernyugalmi függvények segédfüggvényeit

$$
\begin{aligned}
& f_{C H}(x)=\frac{1}{1+\exp \left(a\left(x-T_{b a ́ z i s, H i H}\right)^{2}+b\left(x-T_{b a ́ z i s, H i H}\right)\right)}, \text { illetve } \\
& f_{F}(x)=\frac{1}{1+\exp \left(c\left(x-T_{\text {bázis,HöH }}\right)\right)}
\end{aligned}
$$

alakban felírva ( $x$ a napi átlaghőmérsékletet jelöli) és felhasználva, hogy $\lim _{-\infty} \exp \left(a\left(x-T_{\text {bázis, HiH }}\right)^{2}+b\left(x-T_{\text {bázis, HiH }}\right)\right)=\lim _{+\infty} \exp \left(a\left(x-T_{\text {bázis,HiH }}\right)^{2}+b\left(x-T_{\text {bázis, HiH }}\right)\right)=+\infty$,

valamint $\quad \lim _{-\infty} \exp \left(c\left(x-T_{\text {bázis,HöH }}\right)\right)=0 \quad$ és $\quad \lim _{+\infty} \exp \left(c\left(x-T_{b a ́ z i s, H o ̈ H}\right)\right)=+\infty$, látható, hogy $\lim _{+\infty} f_{C H}=\lim _{-\infty} f_{C H}=0$ és $\lim _{-\infty} f_{F}=0$ és $\lim _{+\infty} f_{F}=1$. Látható továbbá, hogy $f_{C H}$ és $f_{F}$ értékkészlete is a ]0,1[ nyílt intervallum.

Az $f_{C H}$ függvényt deriváljuk:

$$
{f^{\prime}}_{C H}(x)=-\left(2 a\left(x-T_{b a ́ z i s, H i H}\right)+b\right) \frac{\exp \left(a\left(x-T_{\text {bázis, HiH }}\right)^{2}+b\left(x-T_{b a ́ z i s, H i H}\right)\right)}{\left[1+\exp \left(a\left(x-T_{b a ́ z i s, H i H}\right)^{2}+b\left(x-T_{b a ́ z i s, H i H}\right)\right)^{2}\right.} .
$$

${f^{\prime}}_{C H}(x)=0$, ha $2 a\left(x-T_{b a ́ z i s, H i H}\right)+b=0$, hiszen a deriváltfüggvény többi tagja mindig pozitív. $f_{C H}^{\prime}$ előjelét megvizsgálva látható, hogy e függvénynek maximuma van az $x=\frac{-b}{2 a}+T_{b a ́ z i s, H i H}$ pontban. A hideghatás $f_{C H}$ segédfüggvényének alakja tehát egy olyan egypúpú görbe, amelynek maximuma az $x=\frac{-b}{2 a}+T_{b a ́ z i s, H i H}{ }^{\circ} \mathrm{C}$-ban mért értékében van, a függvény pozitív és negatív végtelenben vett határértéke pedig zérus.

Az $f_{F}$ függvényt kétszer deriváljuk, a második deriváltat $1+\exp \left(c\left(x-T_{\text {bázis,HöH }}\right)\right)$-val egyszerüsítjük:

$$
\begin{aligned}
& {f^{\prime}}_{F}(x)=\frac{-c \exp \left(c\left(x-T_{\text {bázis,HöH }}\right)\right)}{\left[1+\exp \left(c\left(x-T_{\text {bázis, HöH }}\right)\right)\right]^{2}} \\
& f^{\prime \prime}{ }_{F}(x)=\frac{-c^{2} \exp \left(c\left(x-T_{b a ́ z i s, H o ̈ H}\right)\right)\left[1+\exp \left(c\left(x-T_{b a ́ z i s, H o ̈ H}\right)\right)\right]+2 c^{2} \exp \left(2 c\left(x-T_{b a ́ z i s, H o ̈ H}\right)\right)}{\left[1+\exp \left(c\left(x-T_{b a ̈ z i s, H o ̈ H}\right)\right)\right]^{3}} .
\end{aligned}
$$

$f_{F}^{\prime}$ mindig pozitív, tehát ez a függvény monoton nő, nincs szélsőértéke. $f^{\prime \prime}{ }_{F}=0$, ha $c^{2} \exp \left(c\left(x-T_{\text {bázis,HöH }}\right)\right)\left[\exp \left(c\left(x-T_{\text {bazzis,HöH }}\right)\right)-1\right]=0$, azaz ha $x=T_{\text {bázis,HöH }} \cdot x<T_{\text {bázis,HöH }}$ esetén $f^{\prime \prime}{ }_{F}$ pozitív, $x>T_{\text {bazis,HöH }}$ esetén $f^{\prime \prime}{ }_{F}$ negatív. A kényszernyugalmi $f_{F}$ segédfüggvény alakja tehát 
egy szigmoid típusú görbe, monoton növekedö, a plusz végtelenben 1, a mínusz végtelenben zérus határértékkel, melynek az $x=T_{\text {bázis,HöH }}$ pontban inflexiós pontja van (18. ábra).
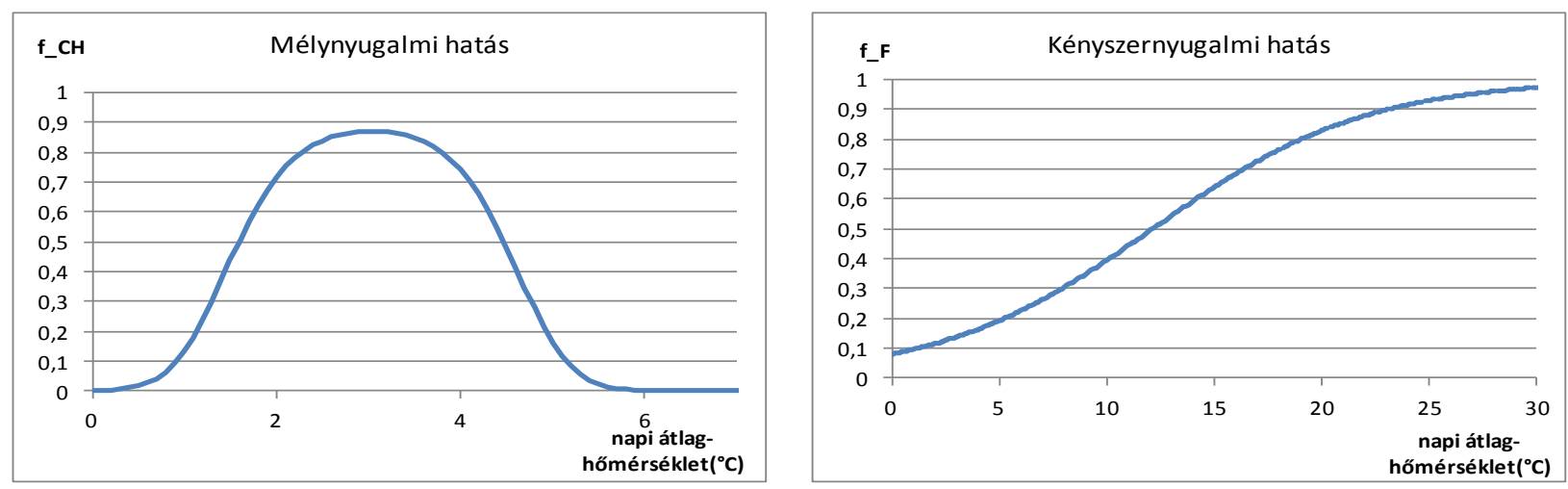

18. ábra: A mélynyugalmi és a kényszernyugalmi időszak hőhatásait leíró $f_{C H}$ és $f_{F}$ függvények jelleggörbéi

A mélynyugalmi és kényszernyugalmi höösszegek akkumulációja látható a 19. ábrán, egy véletlenszerủen kiválasztott év adataival. A vízszintes vonalak jelölik a mélynyugalmi hideghatás akkumulációs kritikus höösszegét $\left(\mathrm{CH}_{k r i t}\right)$, valamint a kényszernyugalom alatt tovább akkumulálódott hatásos kritikus hőösszeget $\left(G D D_{u_{-} k r i t}\right)$. A függőleges vonalak a mélynyugalmi időszak végének és a rügyfakadás modell által jelzett időpontjait jelzik.

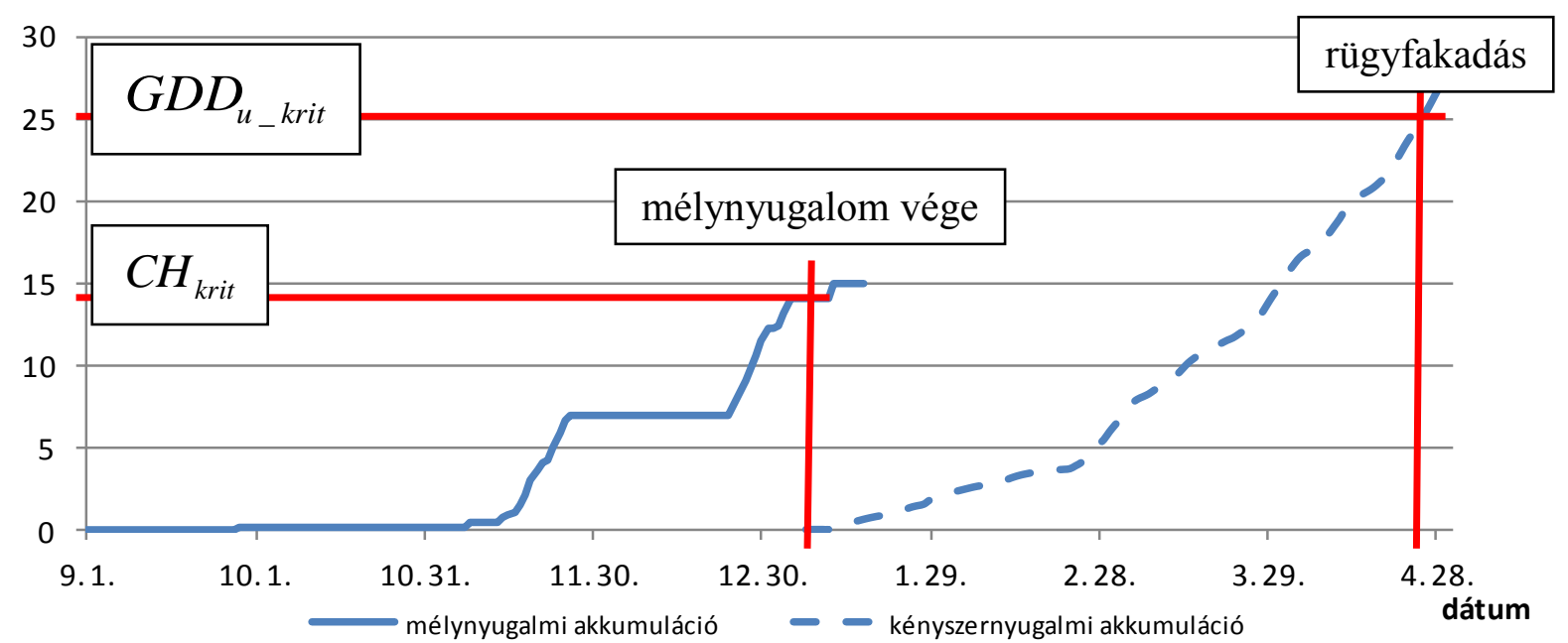

19. ábra: Az $f_{C H}$-val és $f_{F}$-fel jelölt mélynyugalmi és kényszernyugalmi hatások $\mathrm{CH}$-val és Ffel jelölt akkumulációja egy véletlenszerüen kiválasztott évben

\section{Illeszkedés és validálás}

A rendelkezésre álló adatsort véletlenszerüen két egyenlő részre osztottuk. Az egyik csoportba tartozó éveket kalibráláshoz használatuk, míg a maradékokat validáláshoz. 
A modell hibáját (RMSE - root mean square error) a megfigyelt ( $\left.R F_{\text {megfigyelt }}\right)$ és a modell által becsült rügyfakadási időpontok $\left(R F_{\text {modell }}\right)$ közötti különbségek átlagának négyzetösszeg gyökeként határoztuk meg napokban,

$$
R M S E=\sqrt{\frac{1}{N} \sum_{j}\left(B B_{\text {megfigyelt }}-B B_{\text {modell }}\right)^{2}}
$$

ahol $N$ az évek számát jelenti. Az optimalizáláshoz használt Palisade’s Risk Evolver program az ún. innovatív genetikai algoritmuson (GA technology) alapul, amely egy több ezer iterációval futtatott sztochasztikus keresési technika. A módszer nagy előnye, hogy a klasszikus optimalizációs eljárásokkal ellentétben nem reked meg egy lokális minimumhelyen, e helyett a teljes értelmezési tartományon keres, ami lehetővé teszi, hogy globális minimumhelyre találjon rá (Weise, 2009).

A UM modell esetében is minimalizáltuk a hibát (RMSE) az innovatív genetikai algoritmussal hét paraméter $-a, b, c, T_{b a ́ z i s, H i H}, T_{b a ́ z i s, H o ̋ o o}, C H_{k r i t}$ és $G D D_{u_{-} k r i t}-$ optimalizálásával a paraméter térben.

\subsection{Statisztikai módszerek}

\subsubsection{T-próbák}

A várható értékre vonatkozó paraméteres próbák közül a rügyfakadási időpontok összevetése páros $t$-próbával történt.

Páros $t$-próbát akkor alkalmazunk, ha a két véletlen mintánk ( $X$ és $Y$ ) nem független, hanem ellenkezőleg: valamely szempont szerint elemeik párosíthatóak. A próba során arra keressük a választ, hogy a két véletlen, nem független minta alapján elfogadható-e az a feltételezésünk, hogy a vizsgált két alapsokaság várható értéke megegyezik. A hipotézisek felírása, a feltételek ellenőrzése, a próbastatisztika számítása hasonlóan történik, mint a kétmintás $t$-próba esetében. A döntést a szignifikanciaszint alapján hozzuk meg (Harnos és Ladányi, 2005).

\subsubsection{Varianciaanalízis}

A megfigyelt és a becsült, illetve előrejelzett rügyfakadás változásait a különböző években, valamint a klimatikus indikátorok összehasonlítását egytényezős varianciaanalízissel végeztük. A varianciaanalízist (ANOVA - Analysis of Variance) akkor alkalmazzák, ha több normális eloszlású alapsokaság várható értékét kívánjuk összehasonlítani. A kérdés az, hogy az alapsokaság egy bizonyos tulajdonságának mért értéke a különféle csoportokban azonos-e. Az egytényezős ANOVA modellje:

$$
X_{i j}=\mu_{i}+\varepsilon_{i j}=\mu+\alpha_{i}+\varepsilon_{i j} \text {, ahol }
$$


$X_{i j}$ a vizsgált valószínűségi változót

$\mu$ a közös várható értéket

$\alpha_{i}$ az $i$-edik csoport hatását

$\varepsilon_{i j}$ a normális eloszlású, zérus várható értékủ hibatagot jelöli.

A normalitás feltételét Kolmogorov-Smirnov- vagy Saphiro-Wilk-teszttel ellenőrizzük, a szóráshomogenitást pedig Levene-teszttel (Harnos és Ladányi, 2005). 


\section{EREDMÉNYEK}

\subsection{A klimatikus indikátorok számítási eredményei}

\subsubsection{A klimatikus indikátorok változásai 1977 és 2003 között Kecskeméten}

A Kecskemétre vonatkozó, 1977 és 2003 közötti napi megfigyelésekböl származó meteorológiai adatok felhasználásával előállítottam a 2.6.1 fejezetben bemutatott 36 klímaindikátort. Az indikátorok átlagait, az adatsorokra illesztett egyenesek meredekségét és az illesztés determinációs együtthatóját, valamint ezek szignifikanciáját tartalmazza a 15. táblázat.

15. táblázat: 1977 és 2003 között Kecskeméten mért éghajlati indikátorok és lineáris trendjük statisztikai jellemzői

\begin{tabular}{|c|c|c|c|}
\hline Indikátorok & átlag & $\mathrm{R}^{2}$ & meredekség \\
\hline Huglin-index $(\mathrm{HI})\left[{ }^{\circ} \mathrm{C}\right]$ & 2193,43 & $0,73 * * *$ & 20,73 \\
\hline Winkler-index $(\mathrm{WI})\left[{ }^{\circ} \mathrm{C}\right]$ & 1709,18 & $0,76^{* * * *}$ & 19,59 \\
\hline Biológiailag hatásos höösszeg $(\mathrm{BEDD})\left[{ }^{\circ} \mathrm{C}\right]$ & 1333,15 & $0,68 * * *$ & 46,56 \\
\hline Júliusi átlaghöm. (MJuT) $\left[{ }^{\circ} \mathrm{C}\right]$ & 22,79 & $0,52 * * *$ & 0,12 \\
\hline Januári átlaghöm. (MJaT) $\left[{ }^{\circ} \mathrm{C}\right]$ & $-0,79$ & $0,26 \mathrm{~ns}$ & 0,08 \\
\hline Tenyészidö átlaghöm. (GSAT) $\left[{ }^{\circ} \mathrm{C}\right]$ & 17,68 & $0,73^{* * *}$ & 0,09 \\
\hline Tenyészidö átlagos max. hömérséklete (GSATX) $\left[{ }^{\circ} \mathrm{C}\right]$ & 22,87 & $0,69 * * *$ & 0,10 \\
\hline Tenyészidö átlagos min. hömérséklete (GSATN) [ $\left.{ }^{\circ} \mathrm{C}\right]$ & 10,52 & $0,32 \mathrm{~ns}$ & 0,03 \\
\hline Szüretidő max. hömérsékletek átlaga $(H M X)\left[{ }^{\circ} \mathrm{C}\right]$ & 26,05 & $0,62 * * *$ & 0,11 \\
\hline Téli min. höm. $(W M N)\left[{ }^{\circ} \mathrm{C}\right]$ & $-16,79$ & $0,10 \mathrm{~ns}$ & 0,05 \\
\hline Érésidö átl. höm. $(\mathrm{RAT})\left[{ }^{\circ} \mathrm{C}\right]$ & 17,41 & $0,62 * * *$ & 0,09 \\
\hline Hideg éjszaka index $(\mathrm{CNI})\left[{ }^{\circ} \mathrm{C}\right]$ & 10,28 & $0,06 \mathrm{~ns}$ & $-0,01$ \\
\hline Kontinentalitás $(\mathrm{CO})\left[{ }^{\circ} \mathrm{C}\right]$ & 23,58 & $0,11 \mathrm{~ns}$ & 0,03 \\
\hline Extrém meleg napok száma (NEHD) [nap] & 4,00 & $0,50 * *$ & 0,30 \\
\hline Meleg napok száma (NHD) [nap] & 29,15 & $0,72 * * *$ & 1,34 \\
\hline Nyári napok száma (NSD) [nap] & 85,08 & $0,65 * * *$ & 1,52 \\
\hline Fagyos napok száma (NFD) [nap] & 62,31 & $0,30 \mathrm{~ns}$ & 0,53 \\
\hline Jeges napok száma (NID) [nap] & 8,19 & $0,05 \mathrm{~ns}$ & $-0,06$ \\
\hline Szölö fagyindex (F8D) [nap] & 12,35 & $-0,05 n s$ & $-0,06$ \\
\hline Szölö súlyos fagyindex (FS15D) [nap] & 2,46 & $-0,09 \mathrm{~ns}$ & $-0,05$ \\
\hline Tavaszi fagyos napok száma (NSFD) [nap] & 14,81 & $0,41 *$ & 0,34 \\
\hline Öszi fagyos napok száma (NFFD) [nap] & 15,38 & $0,05 \mathrm{~ns}$ & 0,04 \\
\hline Gladstones féle tavaszi fagyindex (SFI_Glad) $\left[{ }^{\circ} \mathrm{C}\right]$ & 12,77 & $0,69 * * *$ & 0,20 \\
\hline Wolf-Boyer féle tavaszi fagyindex $(S F I+W B)\left[{ }^{\circ} \mathrm{C}\right]$ & 5,82 & $0,53 * *$ & 0,04 \\
\hline Júliusi hömérsékleti terjedelem $(\mathrm{DR})\left[{ }^{\circ} \mathrm{C}\right]$ & 24,97 & $0,58 * *$ & 0,20 \\
\hline Áprilisi átlagos napi höingás (MADR) [ $\left.{ }^{\circ} \mathrm{C}\right]$ & 11,65 & $0,53 * *$ & 0,08 \\
\hline Szüreti átlagos napi höingás $(M H D R)\left[{ }^{\circ} \mathrm{C}\right]$ & 12,48 & $0,24 \mathrm{~ns}$ & 0,04 \\
\hline Érésidei napi höingás összege $(E T)\left[{ }^{\circ} \mathrm{C}\right]$ & 1918,93 & $0,48 *$ & 10,21 \\
\hline Riberau-Gayon-Peynaud Index $(R G P)\left[{ }^{\circ} C\right]$ & 2031,86 & $0,58 \mathrm{~ns}$ & 18,63 \\
\hline Éves csapadékmennyiség (AR) [mm] & 473,98 & $0,22 \mathrm{~ns}$ & 2,94 \\
\hline Nyári csapadékmennyiség (SR) [mm] & 108,07 & $0,13 \mathrm{~ns}$ & 0,68 \\
\hline Téli csapadékmennyiség (WR) [mm] & 159,63 & $0,01 \mathrm{~ns}$ & 0,06 \\
\hline Tenyészidö csapadékmennyiség (GSR) [mm] & 316,69 & $0,28 \mathrm{~ns}$ & 2,89 \\
\hline Virágzáskori csapadékmennyiség $(B P R)[\mathrm{mm}]$ & 60,77 & $0,04 \mathrm{~ns}$ & $-0,20$ \\
\hline Érésidö csapadékmennyiség (RPR) [mm] & 79,43 & $0,30 \mathrm{~ns}$ & 1,47 \\
\hline Tenyészidö csapadékos napjainak sz. (GSRD) [nap] & 59,85 & $0,14 \mathrm{~ns}$ & $-0,18$ \\
\hline
\end{tabular}

*p<0,05; **p<0,01; $\mathrm{p}<0,001$ ns: nem szignifikáns

A megfigyelt 27 év alatt (1977-2003) szignifikáns emelkedés következett be $p<0,001$ szinten minden hőmérsékleti indikátor esetén, kivéve a januári átlaghőmérsékletet (MJaT), a 
tenyészidőszak átlagos minimum-hőmérsékletét (GSATN), a téli minimum-hőmérsékletet $(W M N)$, a hideg éjszaka indexet $(C N I)$ és a kontinentalitást $(C O)$.

Szintén szignifikáns növekedést mutat az extrém meleg (NEHD), a meleg (NHD) és a nyári $(N S D)$ napok száma, míg a fagyos napok száma (NFD), a jeges napok száma (NID), a szőlő fagyindex $(F 8 D)$ és a szőlő súlyos fagyindex $(F S 15 D)$ nem változott szignifikánsan a térségben a megfigyelt időszakban. Szignifikánsan növekedett a tavaszi (NSFD) és öszi fagyos (NFFD) napok száma.

Érdemes felfigyelni arra, hogy a Gladstones-féle $\left(S F I_{\mathrm{Glad}}\right)$ és a Wolf-Boyer-féle $\left(S F I_{\mathrm{Glad}}\right)$ fagyindexek, valamint a július havi hőmérséklet terjedelme $(D R)$, az áprilisi átlagos napi hőingás $(M A D R)$, valamint az érésidei napi hőmérséklet-ingadozás összege $(E T)$ is szignifikáns növekedést mutatott, ami a változékony hömérsékleteknek tudható be.

Nem történt azonban szignifikáns változás a csapadékindikátorok esetében.

\subsubsection{A klimatikus indikátorok a RegCM3.1 regionális klímamodell becslései alapján, összevetve a megfigyelt adatokkal}

A klímaindikátorok értékeinek számítását a RegCM3.1 regionális klímamodell becsléseire támaszkodva is elvégeztem. Arra kerestem a választ, hogy milyen változást prognosztizál a modell a 2021-2050-es és a 2071-2100-as időszakokra az IPCC által rögzített, világszerte elfogadott és az összehasonlításokhoz használt 1961-1990-es referencia-időszakot figyelembe véve (New et al., 1999).

A megfigyelt és a jövőben várható hőmérsékleti, extremális, illetve csapadékindikátorok fent említett idősorokra vett átlagértékeit és szórásait találhatjuk a 16. a 17. és a 18. táblázatban.

\section{Hömérsékleti indikátorok}

Magyarországi viszonyok között az Huglin-féle heliotermikus index $(H I)$ érték sok éves átlagban mintegy $1900-2100{ }^{\circ} \mathrm{C}$ között változik (Kozma, 1991). A Kecskeméten mért napi közép- és maximumhőmérséklet-adatokból számított értékek jól tükrözik ezt az átlagértéket 1985-ig. Az 1986-os évtől láthatóvá válik az indikátorértékek emelkedése, 1997 és 2003 között pedig már $2200{ }^{\circ} \mathrm{C}$ fölött marad, a növekedés szignifikáns $(\mathrm{p}<0,001)$. A vizsgált 27 év átlagos Huglin-index értéke $2193{ }^{\circ} \mathrm{C}$, az átlagos szórás $231^{\circ} \mathrm{C}$ (16. táblázat). Vessük össze ezt azzal, hogy a szőlőtermesztés alsó határa $1400{ }^{\circ} \mathrm{C}$ közelében van, a Chardonnay és a Rajnai rizling fajtáknak hozzávetőlegesen $1700{ }^{\circ} \mathrm{C}$ hőösszegigénye van, a Kékfrankos fajta pedig $1800{ }^{\circ} \mathrm{C}$ hőösszegigényü (Kozma, 1991). Tehát már a historikus adatok Huglin-index-értékei is bőven meghaladják ezeknek a fajtáknak a höösszegigényét.

A 20. ábrán az Huglin- és a Winkler-index értékek négy idősorának eredményei láthatóak. A klímamodell által becsült 1961-1990-es időszakban az HI átlagértéke $1815^{\circ} \mathrm{C}$ (20. ábra), mely szignifikánsan kisebb, mint 1977 és 2003 között $(p<0,001)$. Az éghajlati modell 2021-2050 
közötti adatsorára $2012{ }^{\circ} \mathrm{C}, 2071$ és 2100 közötti időszakra már $2462{ }^{\circ} \mathrm{C}$ átlagos höösszegértéket becsül, az idősorok eredményei páronként szignifikánsan eltérnek $(\mathrm{p}<0,05)$.

16. táblázat: Hőmérséklet indikátorok átlag és szórás eredményei (kerekített értékek) a 19772003-as megfigyelt időszakra, illetve a RegCM3.1 regionális klímamodell 1961-1990-es, 20212050-es és a 2071-2100-as becsült adataiból számítva az idősorok páronkénti összehasonlításával

\begin{tabular}{|c|c|c|c|c|c|c|c|c|}
\hline \multirow{2}{*}{$\begin{array}{c}\text { Hömérsékleti } \\
\text { indikátorok }\end{array}$} & \multicolumn{2}{|c|}{$1977-2003$} & \multicolumn{2}{|c|}{ 1961-1990 } & \multicolumn{2}{|c|}{$2021-2050$} & \multicolumn{2}{|c|}{$2071-2100$} \\
\hline & átlag & szórás & átlag & szórás & átlag & szórás & átlag & szórás \\
\hline $\begin{array}{l}\text { Huglin-index }(\mathrm{HI}) \\
{\left[{ }^{\circ} \mathrm{C}\right]}\end{array}$ & 2193 a & 231 & $1815 \mathrm{~b}$ & 175 & 2012 c & 207 & $2462 d$ & 232 \\
\hline $\begin{array}{l}\text { Winkler-index } \\
\left(\text { WI }\left[{ }^{\circ} \mathrm{C}\right]\right.\end{array}$ & 1709 a & 208 & $1255 \mathrm{~b}$ & 142 & $1439 c$ & 177 & $1879 d$ & 191 \\
\hline $\begin{array}{l}\text { Biológiailag hatásos } \\
\text { höösszeg (BEDD) } \\
{\left[{ }^{\circ} \mathrm{C}\right]}\end{array}$ & $1333 \mathrm{c}$ & 99 & 1073 a & 94,5 & $1203 \mathrm{~b}$ & 100 & $1394 \mathrm{c}$ & 85 \\
\hline $\begin{array}{l}\text { Júliusi átlaghöm. } \\
(M J u T)\left[{ }^{\circ} \mathrm{C}\right]\end{array}$ & $23 \mathrm{~b}$ & 2 & 20 a & 2 & 21 a & 2 & $24 \mathrm{c}$ & 2 \\
\hline $\begin{array}{l}\text { Januári átlaghöm. } \\
(\text { MJaT })\left[{ }^{\circ} \mathrm{C}\right]\end{array}$ & $-1 \mathrm{a}$ & 3 & $1,5 \mathrm{~b}$ & 2 & $3 \mathrm{~b}$ & 2 & $4 \mathrm{c}$ & 2 \\
\hline $\begin{array}{l}\text { Tenyészidöszak } \\
\text { átlaghöm }(G S A T)\left[{ }^{\circ} \mathrm{C}\right]\end{array}$ & $18 \mathrm{c}$ & 1 & 15 a & 1 & $16 \mathrm{~b}$ & 1 & $19 \mathrm{~d}$ & 1 \\
\hline $\begin{array}{l}\text { Tenyészidöszak } \\
\text { átlagos maxhöm. } \\
(G S A T X)\left[{ }^{\circ} \mathrm{C}\right]\end{array}$ & $23 \mathrm{~b}$ & 1 & $21 \mathrm{a}$ & 1 & $22 \mathbf{a b}$ & 1 & $25 \mathrm{c}$ & 1 \\
\hline $\begin{array}{l}\text { Tenyészidöszak } \\
\text { átlagos minhöm. } \\
(G S A T N)\left[{ }^{\circ} \mathrm{C}\right]\end{array}$ & $11 \mathrm{a}$ & 1 & 11 a & 1 & $12 \mathrm{~b}$ & 1 & $13 \mathrm{c}$ & 1 \\
\hline $\begin{array}{l}\text { Szüretidei átlagos } \\
\text { maxhőm. }(H M X) \text {, } \\
{\left[{ }^{\circ} \mathrm{C}\right]}\end{array}$ & $26 \mathrm{~b}$ & 1 & 24 a & 1 & $25 \mathrm{ab}$ & 2 & $28 \mathrm{c}$ & 2 \\
\hline $\begin{array}{l}\text { Téli minhöm.(WMN), } \\
{\left[{ }^{\circ} \mathrm{C}\right]}\end{array}$ & $-17 a$ & 4 & $-11 b$ & 4 & $-8 c$ & 3 & $-5 d$ & 3 \\
\hline $\begin{array}{l}\text { Érésidei } \\
\text { középhöm.(RAT) }\left[{ }^{\circ} \mathrm{C}\right]\end{array}$ & $17 \mathrm{~b}$ & 1 & $15 \mathrm{a}$ & 1 & $16 \mathrm{a}$ & 1 & $18 \mathrm{~b}$ & 2 \\
\hline $\begin{array}{l}\text { Hideg éjszaka index } \\
(C N I)\left[{ }^{\circ} \mathrm{C}\right]\end{array}$ & 10 a & 1 & $11 \mathrm{~b}$ & 1 & 11 a & 1 & $14 \mathrm{~b}$ & 2 \\
\hline $\begin{array}{l}\text { Kontinentalitás }(\mathrm{CO}) \\
{\left[{ }^{\circ} \mathrm{C}\right]}\end{array}$ & $24 \mathrm{~b}$ & 2 & 19 a & 2 & 18 a & 2 & $20 \mathrm{a}$ & 3 \\
\hline
\end{tabular}

A különbözö betük szignifikánsan különbözö értékeket jelölnek p <0,05 szinten.

Mivel a megfigyelt időszak időrendben a referencia-időszak és a 2021-2050-es időszelet között helyezkedik el, ezért az ábra alapján megállapíthatjuk, hogy a megfigyelt értékek mindkét index esetében nagyobb fokú melegedést mutatnak a referencia-időszakhoz képest, mint azt a klímamodell a 21. század közepéig prognosztizálta. Ebből következően a 2071-2100-as időszeletre az ábrán láthatónál nagyobb felmelegedésre kell számítanunk, azaz a klímamodell elörejelzésénél pesszimistább változásra számíthatunk. Az évszázad végére tehát 
megközelíthetjük vagy elérhetjük Kalifornia, Közép-Olaszország vagy Észak-Spanyolország napjainkban érvényes $2500{ }^{\circ} \mathrm{C}$ körüli Huglin-index értékeit (Jones et al., 2009).
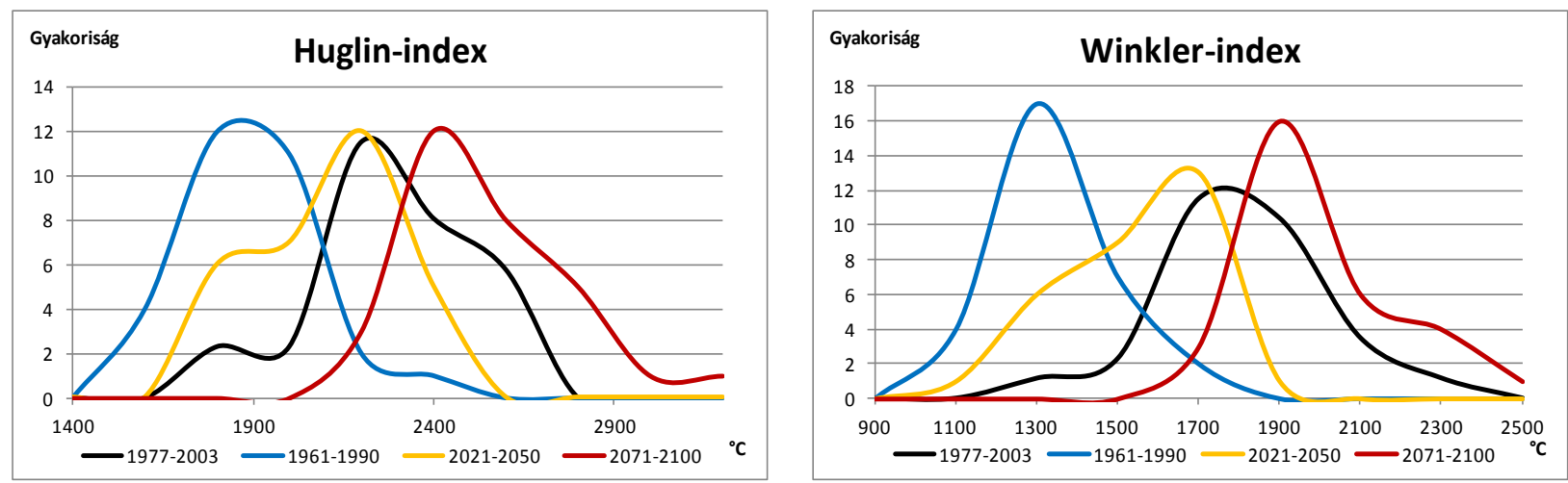

20. ábra: Az Huglin- és Winkler-index értékek 30 évre vetített gyakorisági hisztogramjai az 1977-2003-ig terjedő megfigyelt adatok esetén és a RegCM3.1 klímamodell 1961-1990-es referencia-időszakára, valamint a 2021-2050-es és 2071-2100-as időszeletekre

A kecskeméti számítások szerint 1977 és 2003 között az átlagos Winkler-index (WI) érték $1709{ }^{\circ} \mathrm{C}, 208^{\circ} \mathrm{C}$-os átlagos szórással. Vagyis ez a termőhely a Winkler-skála szerint a III. (meleg mérsékelt) régióba tartozik. Az évenkénti adatok ebben az esetben is szignifikánsan emelkedő tendenciát mutatnak ( $<<0,001)$. A legnagyobb Winkler-index érték $\left(2157^{\circ} \mathrm{C}\right)$ a 2000 es évben gyült össze. 1961 és 1990 között a klímamodell átlagosan $1255^{\circ} \mathrm{C}$-ot becsült (20. ábra, hűvös kategória), 2021 és 2050 között $1439^{\circ} \mathrm{C}$-ot (mérsékelt kategória), míg 2071 és 2100 között már $1879{ }^{\circ} \mathrm{C}$-ot (meleg-mérsékelt). Az idősorok eredményei páronként szignifikánsan eltérnek $(\mathrm{p}<0,05)$.

A hatásos hőösszegnek a borok minősége alakulására gyakorolt hatásának több mint 100 éves adatokra kiterjedő vizsgálata alapján arra a következtetésre jutottak, hogy a borok minősége a hatásos hőmennyiség növekedésével javul, csökkenésével pedig romlik (Kozma, 1991). Csepregi (1997) az 1950-es évektől évjáratkutatásokat végzett Kecskemét Miklóstelepen a teljes höösszeg $\left(0^{\circ} \mathrm{C}\right.$ feletti napi középhömérsékletek összege a tenyészidőn belül) és a hatásos höösszeg $\left(+10{ }^{\circ} \mathrm{C}\right.$ feletti napi középhőmérsékletek összege a tenyészidőn belül) értékek vonatkozásában. 50 éves átlagban a teljes höösszeg Miklóstelepen $3256{ }^{\circ} \mathrm{C}$ volt, míg a hatásos hőösszeg $1356{ }^{\circ} \mathrm{C}$. A minőségi borszőlőtermesztésnek az $1200^{\circ} \mathrm{C}$ feletti hatásos hőösszegek kedveznek (Csepregi, 1997). 


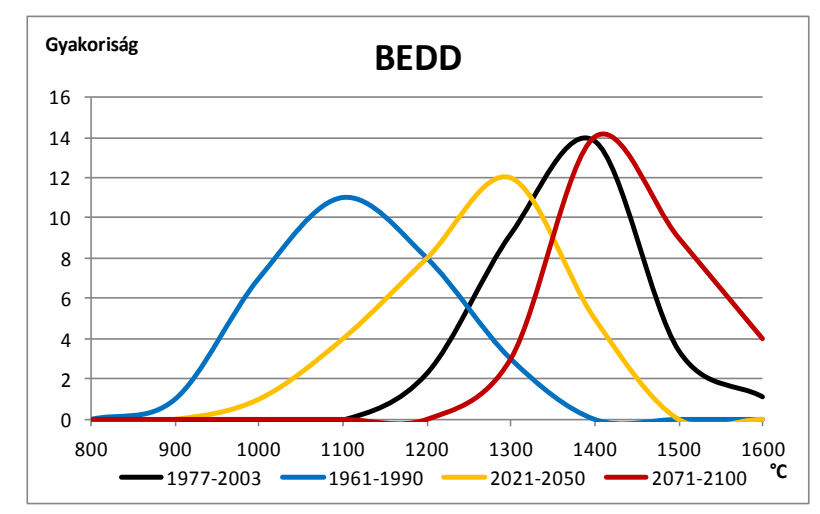

21. ábra: A biológiailag hatásos hőösszeg értékek $(B E D D) 30$ évre vetített gyakorisági hisztogramjai az 1977-2003-ig terjedő megfigyelt adatok esetén és a RegCM3.1 klímamodell 1961-1990-es referencia-időszakára, valamint a 2021-2050-es és 2071-2100-as időszeletekre

A biológiailag hatásos höösszeg (BEDD) kecskeméti átlagos értéke 1977 és 2003 között $1333{ }^{\circ} \mathrm{C}, 99^{\circ} \mathrm{C}$-os átlagos szórással (21. ábra). 2000-ben volt a legmagasabb ez az érték, $1594{ }^{\circ} \mathrm{C} .1961$ és 1990 között $1073{ }^{\circ} \mathrm{C}$ átlagos értéket becsültünk, 94,5 ${ }^{\circ} \mathrm{C}$ szórással. 2021 és 2050 között $1203^{\circ} \mathrm{C}$-ot, 2071 és 2100 közötti időszakra pedig már $1394{ }^{\circ} \mathrm{C}$-ot, $85^{\circ} \mathrm{C}$ szórással. A változás a megfigyelt időszakban (1977-2003) szignifikáns ( $\mathrm{p}<0,001)$. A megfigyelt időszakhoz képest a becsült (1961-1990) és az első előrejelzett időszak (2021-2050) változásai szintén szignifikánsak ( $\mathrm{p}<0,001)$. A 2071 és 2100 közötti időszakra elörejelzett átlagérték a megfigyelt időszakhoz képest nem tér el szignifikánsan $(\mathrm{p}=0,418)$.

A júliusi középhőmérséklet Magyarországon 50 éves átlagban 20,1-22,7 ${ }^{\circ} \mathrm{C}$ (Kozma, 1991). Kecskeméten $26^{\circ} \mathrm{C}$-os júliusi középhőmérsékletet mértek 1994-ben és 1996-ban. 1977 és 2003 között átlagos júliusi középhőmérséklet $(M J u T) 23{ }^{\circ} \mathrm{C}$ volt. Ez szignifikáns emelkedést mutat $(\mathrm{p}<0,01)$. A három becsült idősor átlagértékei a júliusi középhömérsékletre $20{ }^{\circ} \mathrm{C}$ (1961-1990), $21{ }^{\circ} \mathrm{C}$ (2021-2050) és $24{ }^{\circ} \mathrm{C}$ (2071-2100). A megfigyelt időszakhoz képest az 1961-1990-es időszak átlagértéke szignifikáns eltérést mutat $(\mathrm{p}<0,001)$. A 2021-2050-es időszak átlagértéke is szignifikánsan eltér a megfigyelt időszaktól, de kisebb mértékben $(p<0,01)$. Még kisebb a különbség, de szignifikáns $(\mathrm{p}<0,05)$ a 2071-2100-as időszak átlagértékének eltérése az 1977 2003-as periódus átlagértékéhez képest. A 30 évre vetített gyakorisági hisztogramon látható a júliusi középhőmérsékletek eltolódása, vagyis a megfigyelt időszak majdnem a 21. század végére becsült átlagértékkel rendelkezik (22. ábra). A szőlőtermesztésnek általában kedvező az éghajlat, ha a júliusi középhőmérséklet legalább $18^{\circ} \mathrm{C}$. A közepes minőségű termések eléréséhez 17 $19^{\circ} \mathrm{C}$ júliusi középhőmérséklet szükséges. A pezsgőbor-alapanyag termesztéséhez a legmelegebb nyári hónapokban (június, július, augusztus) $16-24{ }^{\circ} \mathrm{C}$, a különleges minőségü borok alapanyagának termesztéséhez $20-28^{\circ} \mathrm{C}$, a szállítható kései érésü csemegeszőlők termesztéséhez $22{ }^{\circ} \mathrm{C}$ feletti, az aszaltszőlőalapanyag-termesztéshez pedig legalább $25^{\circ} \mathrm{C}$ középhőmérséklet szükséges (Bényei et al., 1999). 

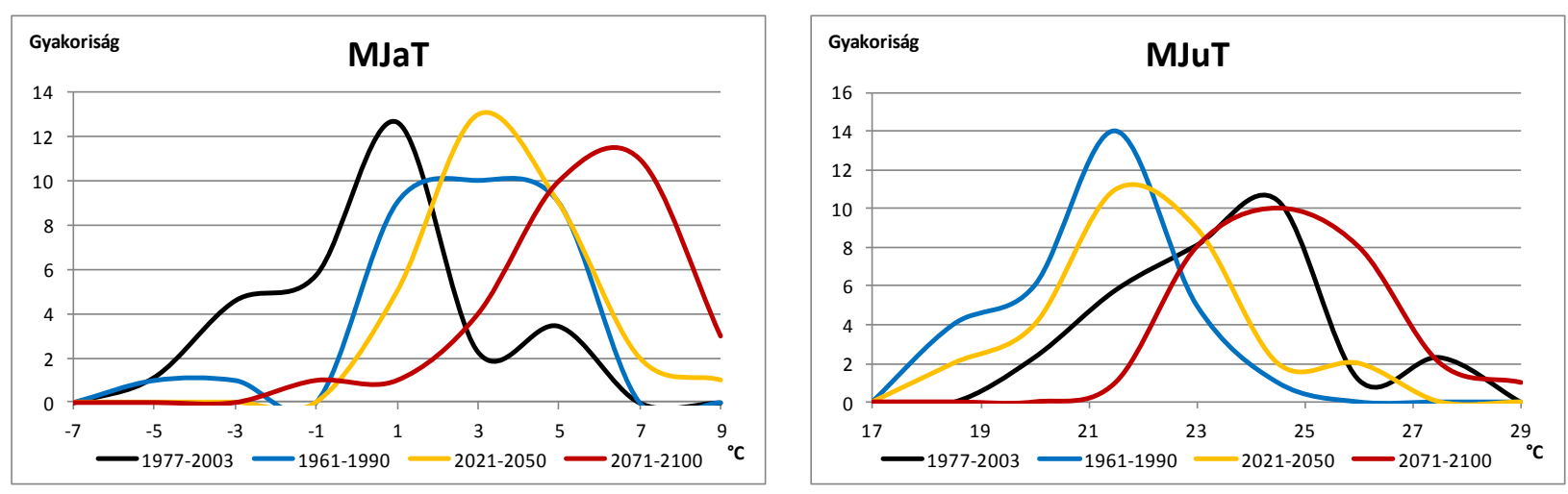

22. ábra: A júliusi és januári átlaghőmérséklet értékek (MJuT, MJaT) 30 évre vetített gyakorisági hisztogramjai az 1977-2003-ig terjedő megfigyelt adatok esetén és a RegCM3.1 klímamodell 1961-1990-es referencia-időszakára, valamint a 2021-2050-es és 2071-2100-as időszeletekre

1977 és 2003 között az átlagos januári középhőmérséklet (MJaT) -1 ${ }^{\circ} \mathrm{C}$. A 27 év alatt legalacsonyabb értékeket 1985-ben $\left(-6^{\circ} \mathrm{C}\right)$ és 1987-ben $\left(-5^{\circ} \mathrm{C}\right)$ mérték. Ennél az indikátornál a megfigyelt 27 év alatt nem történt szignifikáns változás ( $\mathrm{p}=0,20)$. A RegCM3.1 klímamodell a januári átlaghőmérsékletre a 1961-1990-es időszakra $1,5^{\circ} \mathrm{C}$-ot becsül (p<0,01), a 2021-2050-es időszakra $3{ }^{\circ} \mathrm{C}$-ot $(\mathrm{p}<0,001)$, (a referencia-időszak és a 2021-2050-es becslés egymástól nem tér el szignifikánsan, $\mathrm{p}=0,132)$; a 2071-2100-as időszakra már $4{ }^{\circ} \mathrm{C}$-ot prognosztizál $(\mathrm{p}<0,001)$. Mindez jelentheti azt, hogy korábban kezdődik a kényszernyugalmi időszakban a hőösszegek gyüjtése a szőlőnövények esetében, korábbi rügyfakadást feltételezve, ami további kockázatnövelő tényező a tavaszi fagykárok szempontjából. A 30 évre vetített gyakorisági ábrán (22. ábra) jól látható a januári középhőmérséklet pozitív értékek felé történő eltolódása a jövőben.

A tenyészidőszakok átlaghőmérséklete (GSAT, 23. ábra) is növekvő tendenciát mutat 1977től 2003-ig (p<0,001). 1977 és 1981 között még csak a $16^{\circ} \mathrm{C}$ és $17^{\circ} \mathrm{C}$-os átlaghőmérsékletek váltják egymást, majd ez az érték 1982 és 1992 között már 17 és $18^{\circ} \mathrm{C}$ között mozog, a magasabb érték gyakoribb elöfordulásával. 1992 és 2003 között nincs $17^{\circ} \mathrm{C}$ alatt a tenyészidőszakok átlaghőmérséklete, inkább a $19{ }^{\circ} \mathrm{C}$-os értékek fordulnak elő. A 27 év vegetációs periódusainak átlagos hőmérséklete $18^{\circ} \mathrm{C}$ volt $(\mathrm{p}<0,001)$. A legmagasabb mért érték 2000-ben $20^{\circ} \mathrm{C}$ volt. Az éghajlati modellünk 1961-1990-re $15^{\circ} \mathrm{C}$-ot becsült, ami a megfigyelt időszakhoz képest kevesebb, a különbség szignifikáns ( $<<0,001)$. A 2021-2050-re $16^{\circ} \mathrm{C}$ és 2071-2100-ra $19^{\circ} \mathrm{C}$ tenyészidei átlaghőmérsékletet jósol, a változás itt is, mindkét esetben szignifikáns $(\mathrm{p}<0,001$ és $\mathrm{p}<0,01)$. A nyári hőmérsékletnek nagy hatása van a minőség alakulására. Magyarországi viszonyok között a június-szeptemberi középhőmérséklet $1{ }^{\circ} \mathrm{C}-\mathrm{kal}$ történő emelkedése a must cukortartalmát literenként mintegy 20 grammal növeli (Bényei et al., 1999). 


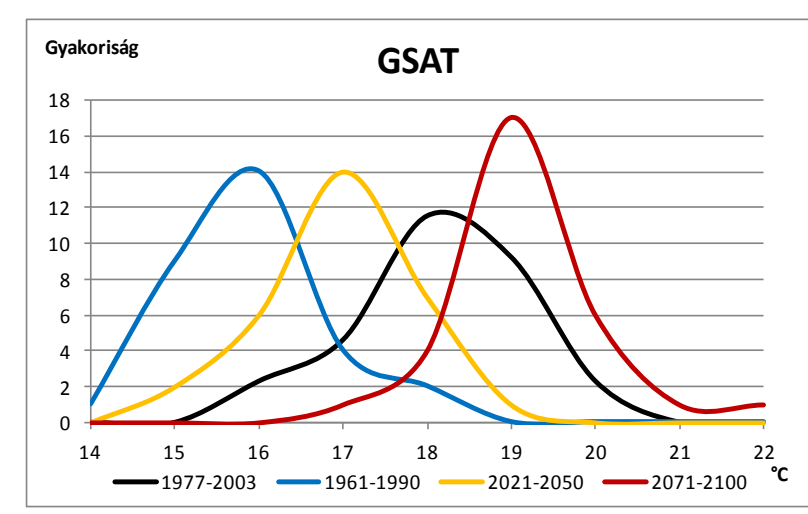

23. ábra: A tenyészidőszak átlaghőmérsékletének (GSAT) 30 évre vetített gyakorisági hisztogramjai az 1977-2003-ig terjedő megfigyelt adatok esetén és a RegCM3.1 klímamodell 1961-1990-es referencia-időszakára, valamint a 2021-2050-es és 2071-2100-as időszeletekre
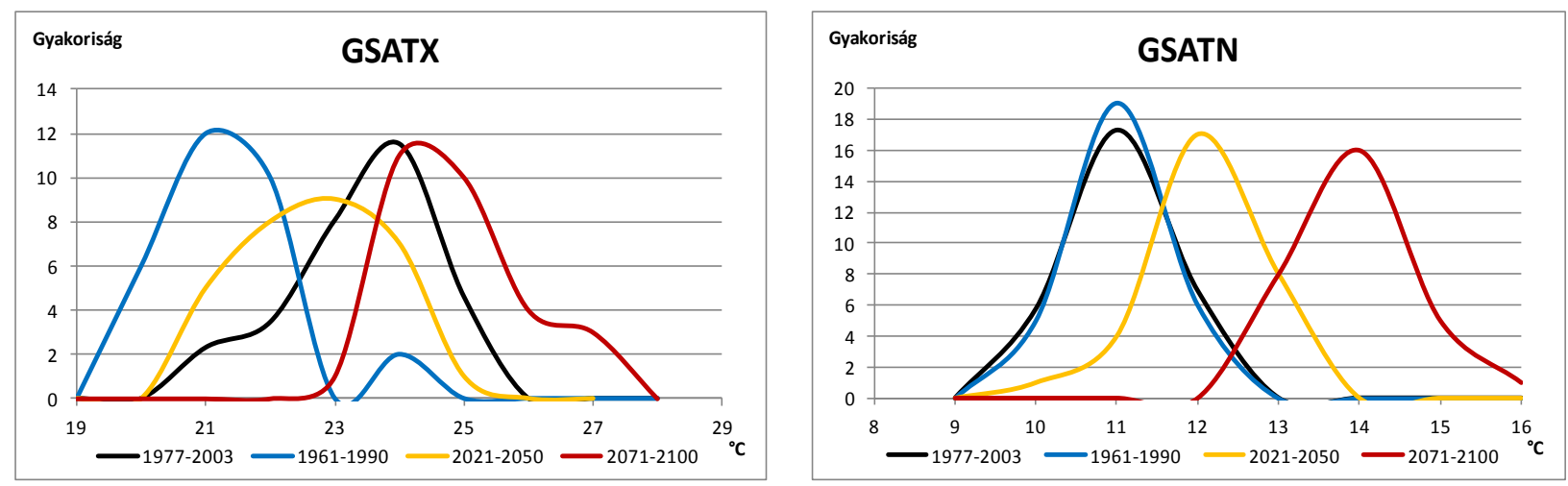

24. ábra: A tenyészidei átlagos maximum- (GSATX) és minimum-hőmérsékletek (GSATN) 30 évre vetített gyakorisági hisztogramjai az 1977-2003-ig terjedő megfigyelt adatok esetén és a RegCM3.1 klímamodell 1961-1990-es referencia-időszakára, valamint a 2021-2050-es és 20712100-as időszeletekre

A tenyészidőszak átlagos maximum-hőmérséklete (GSATX, 24. ábra) az elmúlt évtizedekben ugyancsak szignifikánsan emelkedett $(\mathrm{p}<0,001)$. Míg a 70 -es évek végén ez az érték csak 20 $22{ }^{\circ} \mathrm{C}$ volt, addig az ezredforduló környékén $23-25^{\circ} \mathrm{C}$-ra emelkedett. A 27 év vegetációs periódusainak átlagos maximum-hőmérséklete $23{ }^{\circ} \mathrm{C}$ volt. A változás ez idő alatt erősen szignifikáns volt $(\mathrm{p}<0,001)$. Éghajlati modellünk a 21 . század végére átlag $25^{\circ} \mathrm{C}$ tenyészidei átlagos maximum-hömérsékletet jelez ( $\mathrm{p}<0,001)$. A megfigyelt időszak a 2021-2050-re becsült értékekhez hasonlít leginkább $(\mathrm{p}=0,165)$.

A tenyészidőszak átlagos minimum-hőmérséklete (GSATN, 24. ábra) az 1977 és 2003 közötti időintervallum kezdetén átlagosan $10{ }^{\circ} \mathrm{C}$ volt, az ezredfordulóra ez az érték $11-12{ }^{\circ} \mathrm{C}$ lett. A 27 év átlagos értéke $11^{\circ} \mathrm{C}$, a változás nem szignifikáns ( $\left.\mathrm{p}=0,11\right)$. A 1961 és 1990 között becsült átlagos érték szintén $11^{\circ} \mathrm{C}$, így itt sincs szignifikáns különbség ( $\left.\mathrm{p}=0,90\right)$. 2021-2050, valamint 2071-2100-ra ezek az átlagértékek 12, illetve $13{ }^{\circ} \mathrm{C}$-ra fognak emelkedni a modell szerint. A változás szignifikáns $(\mathrm{p}<0,001)$. Ezeket az eredményeket jól tükrözik a 24. ábra 30 évre vetített gyakorisági hisztogramjainak görbéi. Az érésidő átlaghőmérséklete (RAT) és a szüreti időszak maximum-hőmérséklete $(H M X)$ szignifikánsan emelkedő tendenciát mutat a megfigyelt években 
(p<0,001, 25. ábra). Az érésidő átlaghőmérséklete 1977 és 2003 között $17{ }^{\circ} \mathrm{C}$ volt. 2100 -ra ez az érték $18{ }^{\circ} \mathrm{C}$-ra változhat $(\mathrm{p}=0,93)$. A 30 évre vetített gyakorisági ábrán jól látható, hogyan tolódik el a jövőben az érésidei átlaghőmérséklet a megfigyelt évekhez képest.

A szüreti idő átlagos maximum-hömérséklete (HMX) 1977-2003 között $26^{\circ} \mathrm{C}$ volt, az új évezred kezdetére szignifikánsan emelkedett $(\mathrm{p}<0,001)$. Ezt az értéket csak a 2071-2100-ra prognosztizált $28{ }^{\circ} \mathrm{C}$-os átlagos maximum-hőmérséklet múlja felül $(\mathrm{p}<0,001)$.
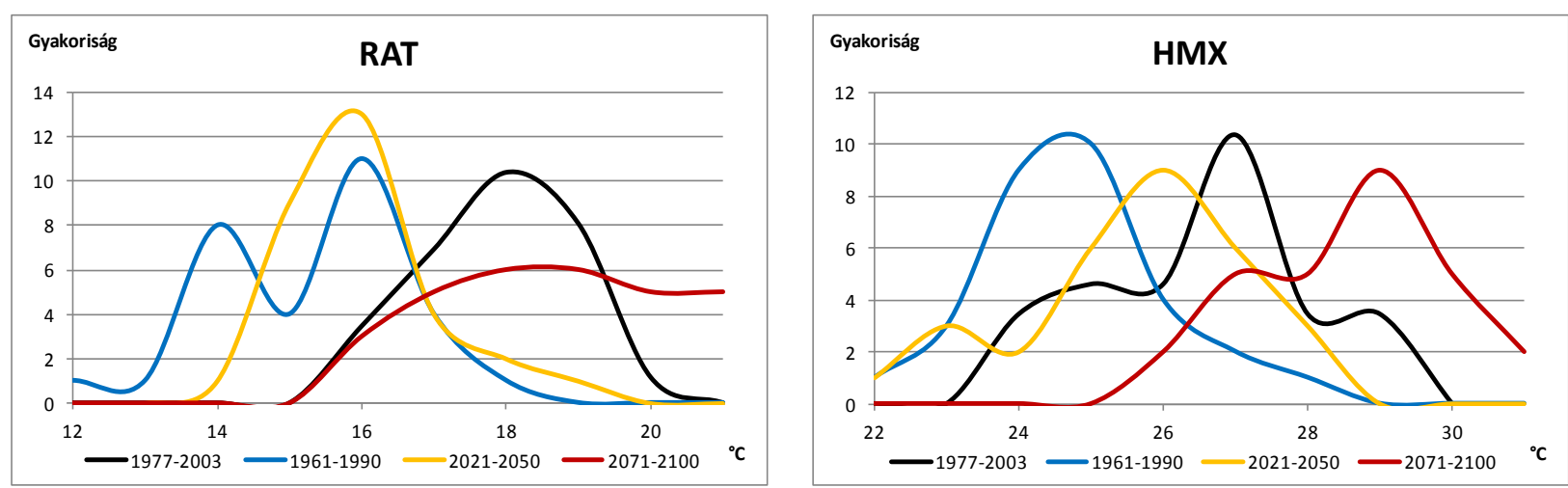

25. ábra: Az érésidő átlaghőmérsékletének (RAT) és a szüretidő átlagos maximumhőmérsékletének (HMX) 30 évre vetített gyakorisági hisztogramjai az 1977-2003-ig terjedő megfigyelt adatok esetén és a RegCM3.1 klímamodell 1961-1990-es referencia-időszakára, valamint a 2021-2050-es és 2071-2100-as időszeletekre

A téli minimum-hőmérséklet $(W M N)$ értékei erős ingadozást mutattak a 27 év alatt, az átlagérték $-17^{\circ} \mathrm{C}, 4^{\circ} \mathrm{C}$-os szórással (26. ábra). Nincs szignifikáns változás az időszak alatt ( $\mathrm{p}=0,61)$. Az 1961 és 1990 közötti időszakra a becslések szerint a téli minimum-hőmérséklet átlagértéke $-11^{\circ} \mathrm{C}$. A jövőben $2021-2050$ között $-8{ }^{\circ} \mathrm{C}$-ra, 2071-2100-ra $-5^{\circ} \mathrm{C}$-ra nőhet ez az érték. Mindhárom érték szignifikáns különbséget jelent a mért időszakhoz képest $(\mathrm{p}<0,001)$. A 26. ábra hisztogramjai jól alátámasztják azt a tendenciát, mely szerint a jövőben a téli minimumhőmérsékletek a magasabb értékek felé közelítenek.
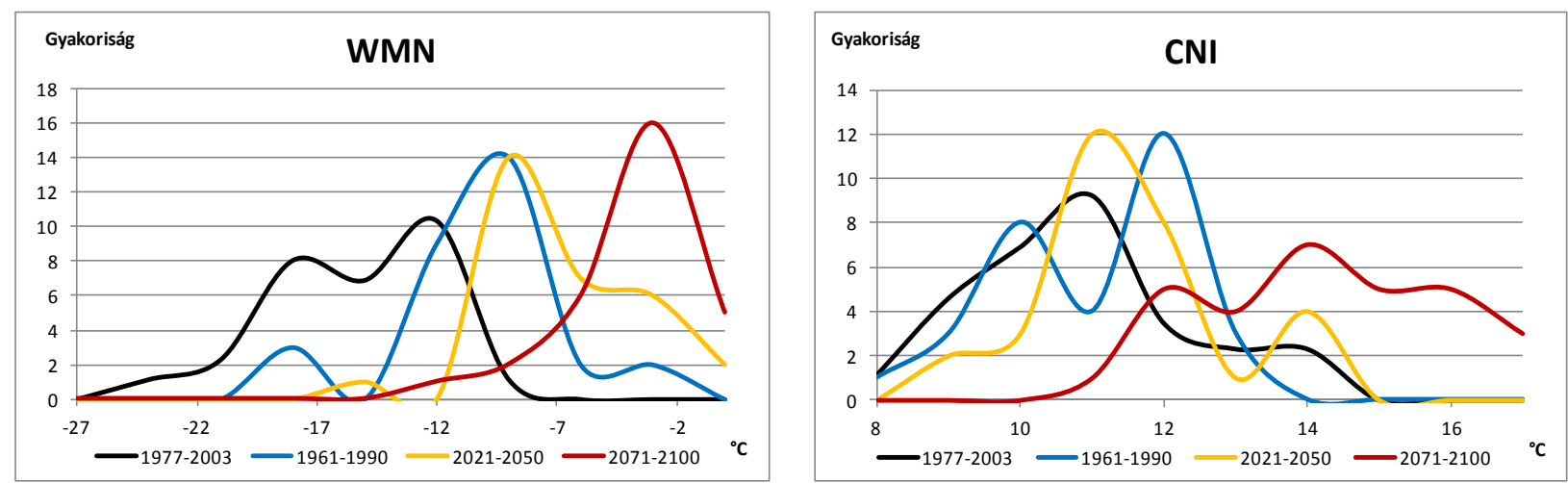

26. ábra: A téli minimum-hőmérséklet (WMN) és a hideg éjszaka index $(C N I)$ értékeinek 30 évre vetített gyakorisági hisztogramjai az 1977-2003-ig terjedő megfigyelt adatok esetén és a RegCM3.1 klímamodell 1961-1990-es referencia-időszakára, valamint a 2021-2050-es és 20712100-as időszeletekre 
A hideg éjszaka index $(C N I)$ a szeptemberi minimum-hőmérsékletek átlagát jelenti (26. ábra). Ennél az indikátornál nem látható lineáris emelkedés vagy csökkenés a 27 éves adatsort tekintve $(\mathrm{p}=0,77)$. Átlagértéke $10{ }^{\circ} \mathrm{C}$, a nagyon hüvös éjszakájú érési időszakot jelenti $(\mathrm{CI}+2)$. Azonban 1961 és 1990 ( $\mathrm{p}=0,44)$, valamint 2021 és $2050(\mathrm{p}<0,05)$ között már $11^{\circ} \mathrm{C}$-ot jelez a modell, majd 2071-2100 között ugrásszerűen megnő ez az érték, és eléri a $14{ }^{\circ} \mathrm{C}$-os átlagot az előrejelzések szerint $(\mathrm{p}<0,001)$, ami már a mérsékelt éjszakájú kategória (CI-1). Tehát szignifikáns változásra számíthatunk a 21. század végéig. Átalánosságban elmondható, hogy a meleg éjszakai hőmérséklettel (CI-2) rendelkező érési időszakra az aromaanyagok elvesztésének tendenciája figyelhető meg. A vörös fajták esetében a viszonylag halvány szín kockázata is megnőhet. Másfelöl a hüvös éjszakai hőmérsékleti feltételek az érés során alapvetően kedvezőek a szőlő szín és aromaanyagai számára. A nagyon hüvös éjszakai hőmérsékletủ érési időszakban $\left(12{ }^{\circ} \mathrm{C}\right.$ alatt), a szőlő szín és aromaanyagainak magas potenciálját fedezték fel, ha a teljes érés feltételei biztosítottak (a legtöbb neves fehérbor ebből az éghajlati zónából származik). Természetesen az érési potenciál nagyon gyenge is lehet, ha a jó érés feltételei, különösen a heliotermikus feltételek, nem biztosítottak (Tonietto és Carbonneau, 2004).

A kontinentális $(C O)$ hatás értékei nem mutatnak szignifikáns eltérést $(\mathrm{p}=0,58)$ a megfigyelt időszakban. A kontinentális hatás a megfigyelt időszakra adta a legmagasabb átlagértéket, $24{ }^{\circ} \mathrm{C}$ ot (27. ábra), 1961-1990-es időszakra $19{ }^{\circ} \mathrm{C}$-ot (p<0,001), 2021-2050-re $18{ }^{\circ} \mathrm{C}$-ot $(\mathrm{p}<0,001)$ és 2071-2100-ra $20^{\circ} \mathrm{C}$-ot $(\mathrm{p}<0,001)$ jósol a modell.

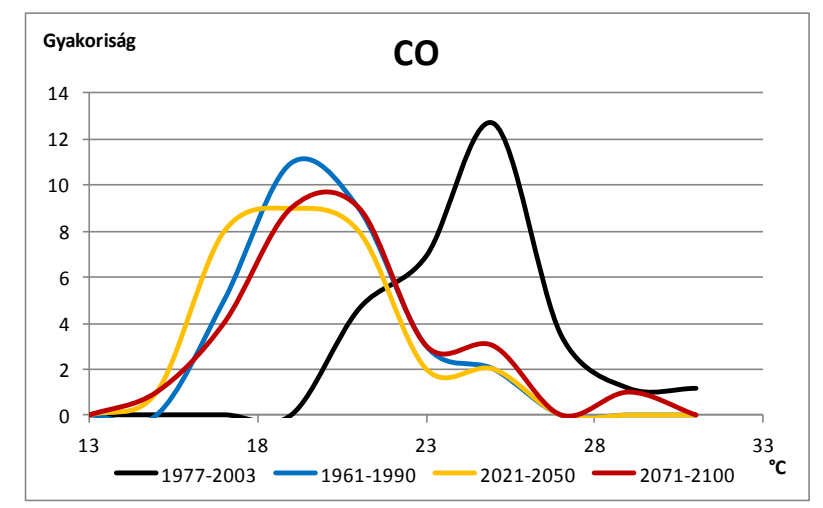

27. ábra: A kontinentális $(C O)$ hatás indexértékeinek 30 évre vetített gyakorisági hisztogramjai az 1977-2003-ig terjedő megfigyelt adatok esetén és a RegCM3.1 klímamodell 1961-1990-es referencia-időszakára, valamint a 2021-2050-es és 2071-2100-as időszeletekre

Száraz, csapadékszegény idővel párosulva a magas hőmérséklet a levél és bogyóperzselést fokozza, különösen a sötét bogyójú fajtáknál (Kozma, 1991). A 30 évre vetített gyakorisági ábrán a becsült (1961-1990) és az előrejelzett időszakok (2021-2050, 2071-2100) szinte fedik egymást, míg a megfigyelt időszak már magasabban fekszik. Ennek oka lehet az is, hogy a júliusi felmelegedés a becsültnél erősebb, a januári megfigyelt középértékek azonban alacsonyabb a becsültnél. Másfelől a modell a kontinentalitás tekintetében nem jósol változást, 
és mi ezt az utóbbit tartjuk valószínünek, a becsültnél némileg magasabb várható júliusi, és nem magasabb, vagy alacsonyabb várható januári hőmérsékletekkel.

\section{Extremális indikátorok}

A vizsgált évek (1977-2003) extrém hőségnapjainak átlagos számát (NEHD), a meleg (NHD) és a nyári napok (NSD) számát a 17. táblázat első három sorában látjuk. Mindhárom indikátor esetében emelkedés figyelhető meg a vizsgált időszakban (28. ábra), a változás szignifikáns $(\mathrm{p}<0,001)$.

17. táblázat: Extremális indikátorok átlag és szórás eredményei az 1977-2003-as megfigyelt időszakra, illetve a RegCM3 regionális klímamodell 1961-1990-es, 2021-2050-es és a 20712100-as becsült meteorológiai adataira alapozva

\begin{tabular}{|c|c|c|c|c|c|c|c|c|}
\hline \multirow[t]{2}{*}{ Extremális indikátorok } & \multicolumn{2}{|c|}{$1977-2003$} & \multicolumn{2}{|c|}{$1961-1990$} & \multicolumn{2}{|c|}{$2021-2050$} & \multicolumn{2}{|c|}{$2071-2100$} \\
\hline & átlag & szórás & átlag & Szórás & átlag & Szórás & átlag & Szórás \\
\hline $\begin{array}{l}\text { Extrém meleg napok } \\
\text { száma (NEHD) [nap] }\end{array}$ & $4 \mathbf{a}$ & 5 & $3 \mathbf{a}$ & 4 & $7 \mathbf{a}$ & 5 & $19 \mathrm{~b}$ & 10 \\
\hline $\begin{array}{l}\text { Meleg napok száma } \\
\text { (NHD) [nap] }\end{array}$ & 29 a & 15 & $21 \mathbf{a}$ & 9 & $27 \mathbf{a}$ & 12 & $53 \mathrm{~b}$ & 16 \\
\hline $\begin{array}{l}\text { Nyári napok száma } \\
\text { (NSD) [nap] }\end{array}$ & $85 \mathrm{~b}$ & 19 & 59 a & 13 & $72 \mathrm{~b}$ & 17 & $102 \mathrm{~d}$ & 16 \\
\hline $\begin{array}{l}\text { Fagyos napok száma } \\
\text { (NFD) [nap] }\end{array}$ & $62 \mathrm{~d}$ & 13 & $47 \mathrm{c}$ & 12 & $34 \mathrm{~b}$ & 12 & 22 a & 12 \\
\hline $\begin{array}{l}\text { Jeges napok száma (NID) } \\
\text { [nap] }\end{array}$ & $8 \mathrm{c}$ & 8 & $3 \mathrm{~b}$ & 5 & $1 \mathbf{a b}$ & 2 & $\mathbf{0} \mathbf{a}$ & 1 \\
\hline $\begin{array}{l}\text { Szölö fagyindex (F8D) } \\
\text { [nap] }\end{array}$ & $12 \mathrm{c}$ & 10 & $4 b$ & 6 & $2 \mathbf{a b}$ & 3 & $\mathbf{0 a}$ & 1 \\
\hline $\begin{array}{l}\text { Szölö súlyos fagyindex } \\
\text { (FS15D) [nap] }\end{array}$ & $2 \mathbf{b}$ & 4 & 0ab & 1 & $\mathbf{0 a}$ & 0 & $\mathbf{0 a}$ & 0 \\
\hline $\begin{array}{l}\text { Tavaszi fagyos napok } \\
\text { száma (NSFD) [nap] }\end{array}$ & $15 \mathrm{~b}$ & 7 & $13 \mathrm{~b}$ & 7 & $8 \mathbf{a}$ & 6 & $5 \mathbf{a}$ & 5 \\
\hline $\begin{array}{l}\text { Őszi fagyos napok száma } \\
(N F F D) \text { [nap] }\end{array}$ & $15 \mathrm{c}$ & 7 & $9 \mathrm{~b}$ & 6 & $6 \mathrm{~b}$ & 4 & $2 \mathrm{a}$ & 2 \\
\hline $\begin{array}{l}\text { Gladstones féle tavaszi } \\
\text { fagyind. }(\text { SFIGlad })\left[{ }^{\circ} \mathrm{C}\right]\end{array}$ & $13 \mathrm{~b}$ & 2 & $11 \mathbf{a}$ & 1 & $12 \mathrm{ab}$ & 2 & $11 \mathrm{a}$ & 2 \\
\hline $\begin{array}{l}\text { Wolf-Boyer féle tavaszi } \\
\text { fagyind. }(\text { SFIWB })\left[{ }^{\circ} \mathrm{C}\right]\end{array}$ & $5,82 \mathrm{c}$ & 1 & $4,59 \mathrm{a}$ & 1 & 5,11 b & 1 & $4,81 \mathrm{ab}$ & 1 \\
\hline $\begin{array}{l}\text { Júliusi hömérsékleti } \\
\text { terjedelem }(\mathrm{DR})\left[{ }^{\circ} \mathrm{C}\right]\end{array}$ & $25 a$ & 3 & $25 a$ & 2 & $26 \mathrm{ab}$ & 3 & $27 \mathrm{~b}$ & 3 \\
\hline $\begin{array}{l}\text { Áprilisi átlagos napi } \\
\text { höingás }(M A D R)\left[{ }^{\circ} \mathrm{C}\right]\end{array}$ & $12 \mathrm{c}$ & 1 & 9 a & 1 & $10 \mathrm{~b}$ & 1 & $10 \mathbf{a b}$ & 1 \\
\hline $\begin{array}{l}\text { Szüreti átlagos napi } \\
\text { höingás }(M H D R)\left[{ }^{\circ} \mathrm{C}\right]\end{array}$ & $12 \mathrm{c}$ & 1 & $10 \mathrm{a}$ & 1 & $10 \mathbf{a b}$ & 1 & $11 \mathrm{~b}$ & 1 \\
\hline $\begin{array}{l}\text { Érésidei napi höingás } \\
\text { összege }(E T)\left[{ }^{\circ} \mathrm{C}\right]\end{array}$ & 1919 c & 172 & 1602 a & 118 & 1642 a & 139 & $1738 \mathrm{~b}$ & 118 \\
\hline $\begin{array}{l}\text { Riberau-Gayon-Peynaud } \\
\text { Index }(R G P)\left[{ }^{\circ} \mathrm{C}\right]\end{array}$ & 2032 c & 259 & 1549 a & 236 & $1791 \mathrm{~b}$ & 287 & $2287 d$ & 280 \\
\hline
\end{tabular}


Az 1961-1990-es időszak extrém meleg napjainak száma a megfigyelt időszakhoz képest nem tér el jelentősen ( $p=0,348)$. A modell a 2021-2050-es időszakra már enyhébb emelkedést jelez ( $\mathrm{p}=0,075$ ). A 2071-2100 közötti időszakra a megfigyelt értékekhez képest az átlagértékek szignifikánsan $(p<0,001)$ megemelkednek, vagyis az egy évben bekövetkező hőségnapok száma az 1977-2003-as átlagos 4 napról, akár 19 napra is emelkedhet az évszázad végére. A túl magas léghömérséklet $\left(>35^{\circ} \mathrm{C}\right)$ következtében a szőlőnövény fotorespirációs, légzési folyamatai felgyorsulnak mind a vegetatív részekben, mind a fürtökben. A disszimilációs, lebontó folyamatok miatt jelentékeny cukorveszteség (főként glükóz) és savveszteség (almasav) alakulhat ki. Ilyen esetekben gyakran indokolt a savszegény borok és a diszharmónia megakadályozása érdekében a must vagy a bor savkiegészítése is (Kádár, 1998).

A különböző betűk szignifikánsan különböző értékeket jelölnek p<0,05 szinten.

A meleg napok száma $(N H D)$ hasonló tendenciát mutat az extrém meleg napok számához. A megfigyelt időszakban ez az érték átlagosan 29 nap. 1961-1990-re ezt a számot 21 napra becsültük. A 2021-2050-es időszakra a modellünk 27 napot jósol ( $p=0,496), 2071-2100$-ra pedig már 53 napot, ami szignifikáns növekedést jelent $(\mathrm{p}<0,001)$.
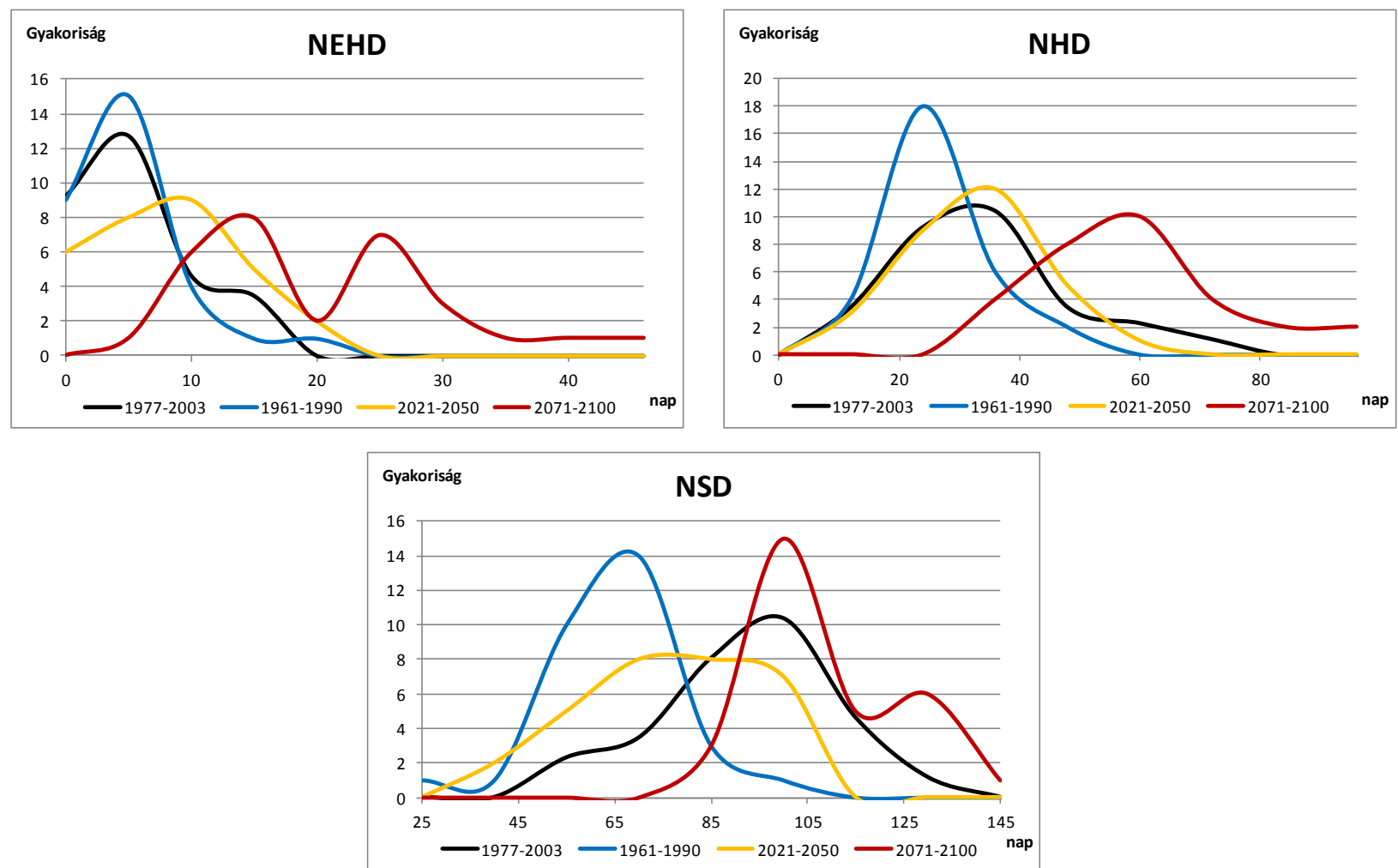

28. ábra: Az extrém meleg napok számának (NEHD), a meleg napok számának $(N H D)$ és a nyári napok számának (NSD) 30 évre vetített gyakorisági hisztogramjai az 1977-2003-ig terjedő megfigyelt adatok esetén és a RegCM3.1 klímamodell 1961-1990-es referencia-időszakára, valamint a 2021-2050-es és 2071-2100-as időszeletekre 
A nyári napok számát tekintve hasonló helyzet alakult ki, szignifikáns emelkedést csak a 2071-2100-as időszakra jósolt a modell ( $\mathrm{p}<0,001)$. Főként a Dél-Alföldön figyelembe kell venni, hogy a $30{ }^{\circ} \mathrm{C}$ feletti hőmérsékleti maximumokkal járó hőségnapok száma lényegesen magasabb (25-30) a többi borvidékre jellemző átlagokhoz (5-10) képest. A több hőségnap kedvezőtlen hatását fokozza, hogy a homoktalajok átforrósodása miatt a szőlöültetvények állományklímája (talajszint felett $1 \mathrm{~m}$ magasságban) akár $5-6{ }^{\circ} \mathrm{C}-\mathrm{kal}$ magasabb lehet, mint a meteorológiai állomásokon meghatározott léghőmérséklet (Teszlák et al., 2009).

A fagyos napok $(N F D)$, a jeges napok $(N I D)$, a tavaszi $(N S F D)$ és az őszi fagyos napok száma (NFFD) vegyes képet mutat (29. ábra). A fagyos napok száma emelkedést mutat 1977 és 2003 között, az eltérés szignifikáns $(\mathrm{p}<0,05)$. Azonban a három becsült idősorra szignifikáns csökkenést jósolt a modell ( $\mathrm{p}<0,001$ ), a századfordulóra ez 30 napra is csökkenhet, szemben a megfigyelt időszak 94 napjához képest.

A jeges napok számában $(N I D)$ nincs szignifikáns különbség $(\mathrm{p}=0,50)$ a megfigyelt éveket összehasonlítva (29. ábra). Ez átlagosan 12 nap évente. A modell szerint a 2021 és 2050-re, valamint 2071 és 2100-ra ez a szám csökkenni fog, 1 illetve akár 0 napra, a várt változás szignifikáns $(\mathrm{p}<0,001)$. A $-8^{\circ} \mathrm{C}$, illetve a $-15^{\circ} \mathrm{C}$ alatti minimumhőmérsékletü napok számában, (szőlő fagyindex, $F 8 D$, szőlő súlyos fagyindex, $F S 15 D)$ nincs szignifikáns különbség $(\mathrm{p}=0,50)$ a megfigyelt éveket összehasonlítva (29. ábra). Ez átlagosan 12,4, illetve 2,5 nap évente. A modell szerint a 2021 és 2050-re, valamint 2071 és 2100-ra ez a szám csökkenni fog akár 0 napra, a várt változás szignifikáns $(\mathrm{p}<0,001)$.

A tavaszi fagyos napok számát (NSFD) tekintve emelkedés történt az ezredforduló környékén, a változás szignifikáns $(\mathrm{p}<0,05,29$. ábra). A jövőben szignifikáns csökkenést várhatunk, mivel 1961-1990-re a modell már csak 13 tavaszi fagyos napot becsült a megfigyelt 15-höz képest, majd az elörejelzések szerint 2021-2050-re ez 8 napra, 2071-2100-ra 5 napra csökkenhet $(\mathrm{p}<0,001)$.

Az őszi fagyos napok száma (NFFD) nem mutat szignifikáns eltérést ( $\mathrm{p}=0,82)$, ha az 1977 és 2003 között megfigyelt időszak átlagértékeit vizsgáljuk (29. ábra). A további vizsgált időszakokra becsült és előrejelzett értékek azonban szignifikáns csökkenést mutatnak $(\mathrm{p}<0,001)$. 

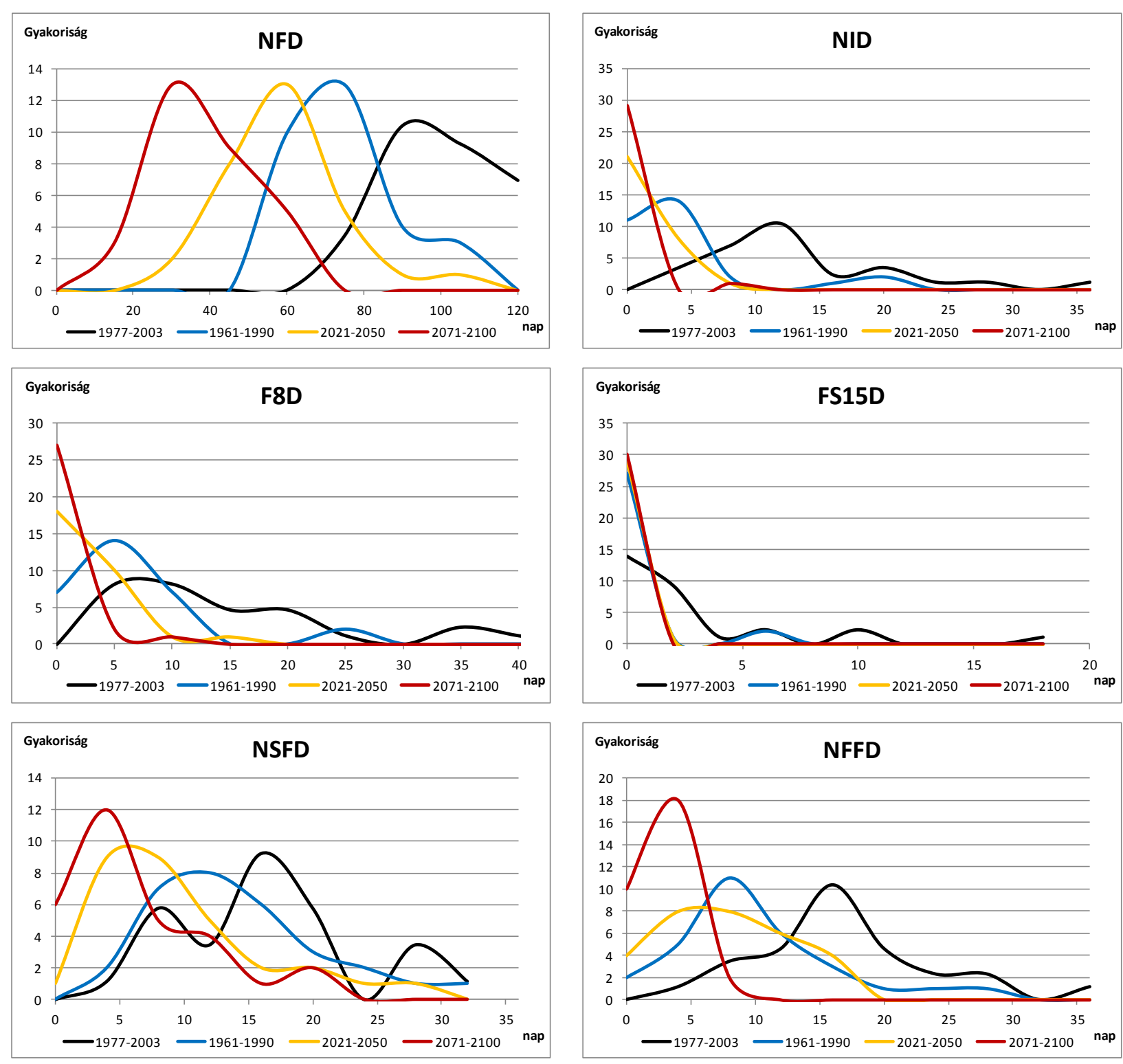

29. ábra: A fagyos $(N F D)$ és jeges napok $(N I D)$ számának, a szőlő fagyindexnek $(F 8 D)$, a szőlős súlyos fagyindexnek (FS15D), valamint a tavaszi (NSFD) és őszi fagyos napok $(N F F D)$ számának 30 évre vetített gyakorisági hisztogramjai az 1977-2003-ig terjedő megfigyelt adatok esetén és a RegCM3.1 klímamodell 1961-1990-es referencia-időszakára, valamint a 2021-2050es és 2071-2100-as időszeletekre

A Gladstones-féle $(p<0,001)$ és a Wolf-Boyer féle tavaszi fagyindex $(p<0,01)$ átlagértékek csökkenő tendenciát mutatnak 1977 és 2003 között (30. ábra). A Gladstones-féle tavaszi fagyindex 1961-1990-re becsült értéke szignifikánsan kisebb $(\mathrm{p}<0,01)$ a megfigyelt időszakhoz képest, de 2021-2050-re a változás nem számottevő ( $\mathrm{p}=0,165)$, ám a 2071-2100-as időszakra az elörejelzés szignifikáns csökkenést mutat $(\mathrm{p}<0,01)$. 

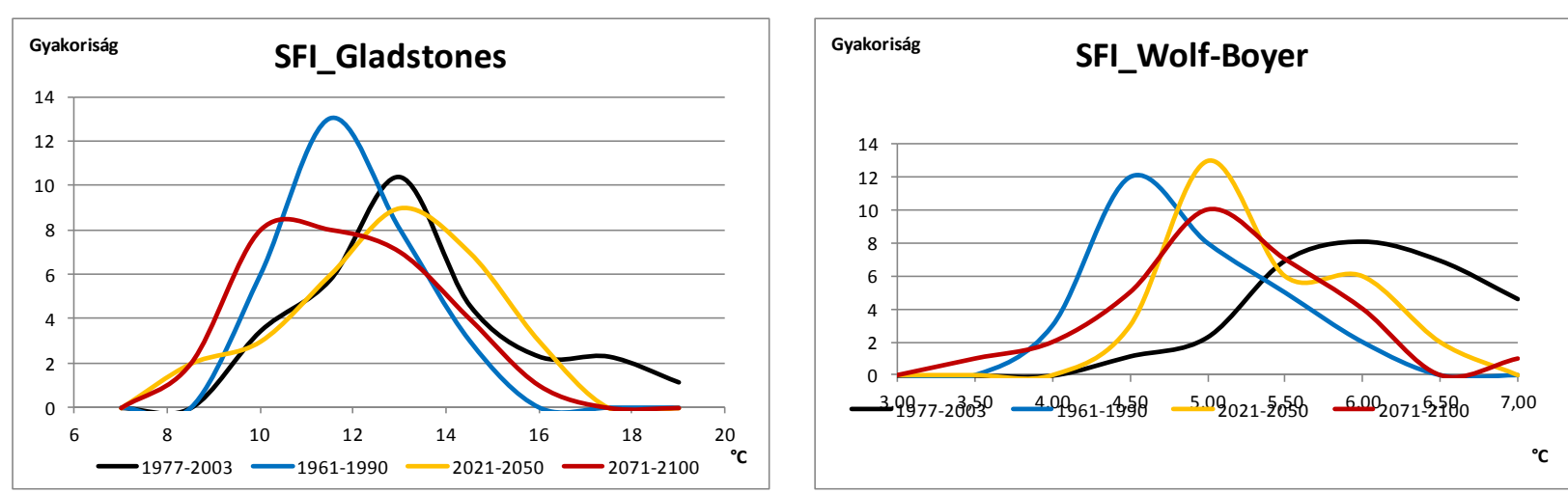

30. ábra: A Gladstones és a Wolf-Boyer-féle tavaszi fagyindexek 30 évre vetített gyakorisági hisztogramjai az 1977-2003-ig terjedő megfigyelt adatok esetén és a RegCM3.1 klímamodell 1961-1990-es referencia-időszakára, valamint a 2021-2050-es és 2071-2100-as időszeletekre

A Wolf-Boyer-féle tavaszi fagyindex 1977 és 2003 között mért átlagértéke csaknem $6{ }^{\circ} \mathrm{C}$, a változás a 27 éven belül szignifikáns (p<0,01). Az 1961-1990-re becsült, a 2021-2050-re és a 2071-2100-ra elörejelzett átlagérték $5{ }^{\circ} \mathrm{C}$ körüli minhárom esetben. A változás a megfigyelt időszakhoz képest szignifikáns ( $\mathrm{p}<0,001)$; a referencia-időszak és a 2021-2050-re előrejelzett időszakok átlagértékeit egymáshoz hasonlítva szignifikáns változást tapasztalunk $(\mathrm{p}<0,05)$, de a két előrejelzett időszak értékei között nem szignifikáns az eltérés ( $\mathrm{p}=0,478)$.

A hőmérséklet júliusi terjedelme (DR) 1977 és 2003 között $25^{\circ} \mathrm{C}$ volt, a változás szignifikáns emelkedést mutat ( $\mathrm{p}<0,01,31$. ábra). 1961-1990-es időszakra a modell szintén $25^{\circ} \mathrm{C}$-ot becsült ( $\left.\mathrm{p}=0,852\right)$. 2021-2050-re ez az érték $26^{\circ} \mathrm{C}$-ra emelkedik ( $\left.\mathrm{p}=0,312\right), 2071-2100$ ra pedig $27^{\circ} \mathrm{C}$-ra $(\mathrm{p}<0,01)$.

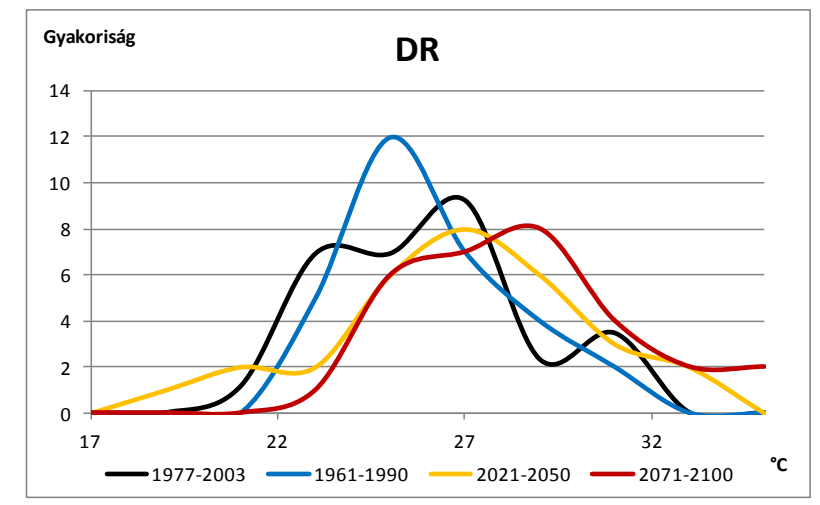

31. ábra: A júliusi hőmérséklet terjedelmének $(D R) 30$ évre vetített gyakorisági hisztogramjai az 1977-2003-ig terjedő megfigyelt adatok esetén és a RegCM3.1 klímamodell 1961-1990-es referencia-időszakára, valamint a 2021-2050-es és 2071-2100-as időszeletekre

Az áprilisi és a szüreti átlagos napi hőingás $(M A D R, M H D R)$, mindkét indikátor esetében mintegy $12{ }^{\circ} \mathrm{C}$ volt 1977 és 2003 között (32. ábra). Az áprilisi átlagos napi hőingás esetében szignifikáns változás történt $(\mathrm{p}<0,01)$, a szüreti átlagos napi hőingás viszont nem mutatott

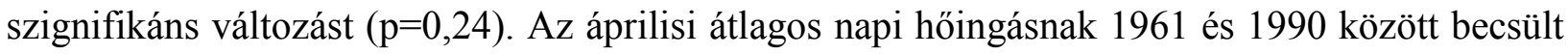
értéke $9{ }^{\circ} \mathrm{C}$ ( $\left.\mathrm{p}<0,001\right), 2021-2050$-re és 2071-2100-ra elörejelzett értéke $10^{\circ} \mathrm{C}$ körüli $(\mathrm{p}<0,001)$. 
A szüreti átlagos napi hőingás a modell szerint szintén szignifikánsan változik a jövőben $(\mathrm{p}<0,001)$.
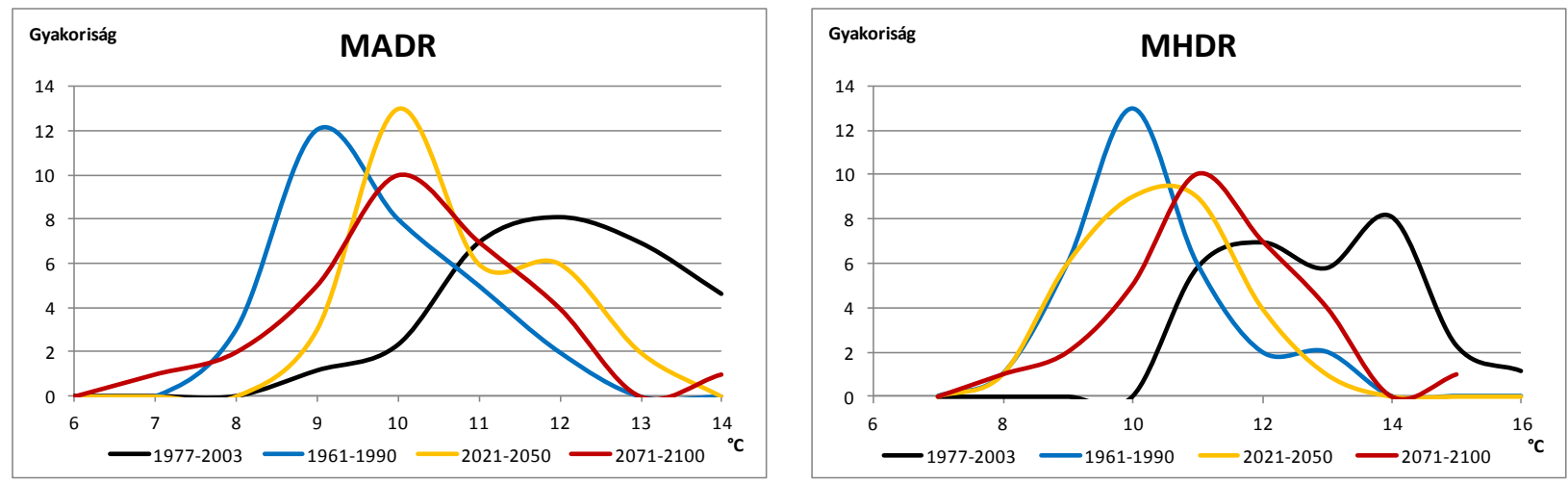

32. ábra: $\mathrm{Az}$ áprilisi $(M A D R)$ és a szüreti $(M H D R)$ átlagos napi hőingás 30 évre vetített gyakorisági hisztogramjai az 1977-2003-ig terjedő megfigyelt adatok esetén és a RegCM3.1 klímamodell 1961-1990-es referencia-időszakára, valamint a 2021-2050-es és 2071-2100-as időszeletekre
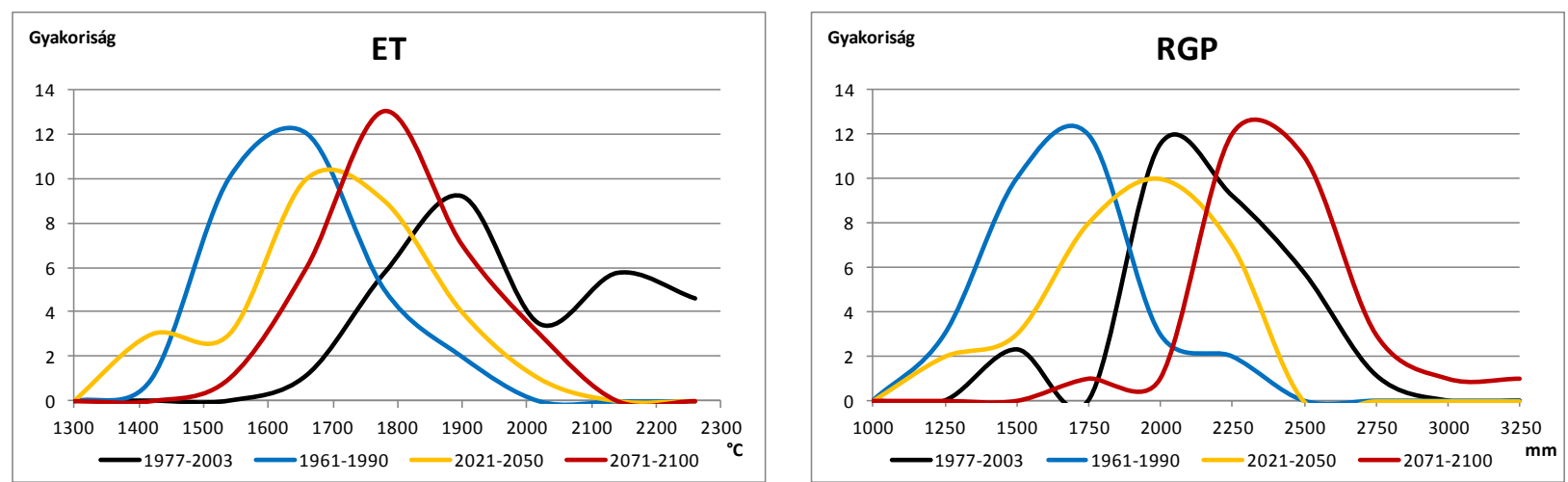

33. ábra: Az érésidei napi hőmérséklet-ingadozás összege (ET) és a Riberau-Gayon-Peynaudindex $(R G P)$ értékeinek 30 évre vetített gyakorisági hisztogramjai az 1977-2003-ig terjedö megfigyelt adatok esetén és a RegCM3.1 klímamodell 1961-1990-es referencia-időszakára, valamint a 2021-2050-es és 2071-2100-as időszeletekre

Az érésidei napi hőmérséklet-ingadozás összegét $(E T)$ június 1-je és október 31-e között mérik (Zorer, 2008), ami a zsendülés, az érés és a szüret idejének hőviszonyairól ad információt. Az 1977 és 2003 között mért átlagos napi hőmérsékleti ingadozás összege $1919{ }^{\circ} \mathrm{C}$ volt. A 27 év alatt a változás szignifikáns $(\mathrm{p}<0,05)$, vagyis növekedés figyelhető meg az ezredforduló környékén a 70-es évek végéhez képest. A megfigyelt időszak átlagértékénél a becsült, 1961 és 1990 közötti időszak átlagértéke jóval alacsonyabb, csupán $1602{ }^{\circ} \mathrm{C}(\mathrm{p}<0,001)$. A 2021-2050-es időszakra elörejelzett napi hőmérséklet-ingadozás összege $1642{ }^{\circ} \mathrm{C}(\mathrm{p}<0,001)$, ami a referenciaidőszakhoz képest nem mutat szignifikáns eltérést $(\mathrm{p}=0,672)$. A 2071-2100 ra előrejelzett átlagérték $1738^{\circ} \mathrm{C} \quad(\mathrm{p}<0,001)$. Ezek az értékek jóval elmaradnak a megfigyelt időszak átlagértékéhez viszonyítva. Ez tükröződik a 33. ábra görbéin is.

A Riberau-Gayon-Peynaud (RGP) evapotranspirációs index értékei a bor alakuló cukor- és savtartalmára vannak hatással. A 30 évre vetített gyakorisági hisztogram görbéi a megfigyelt 
időszakhoz képest szignifikáns növekedést csak a 2071-2100-as időszakra jeleznek ( $<<0,01,33$. ábra). A megfigyelt időszakon belül (1977-2003) a változás szignifikáns ( $<<0,01)$.

\section{Csapadékindikátorok}

A jövőbeli éghajlatváltozás kapcsán a csapadékmennyiségek változásának előrejelzése a legbizonytalanabb tényező (34. ábra). A legtöbb előrejelzés a Kárpát-medence területére csökkenő csapadékmennyiséget jelez. Ezért a csapadékmennyiségek mérése, kiértékelése igen nagy jelentőségü. Az 1977 és 2003 között mért csapadékindikátorok eltérései nem szignifikánsak. Az éves csapadékmennyiség a 27 év alatt nem változott $(p=0,28)$. A nyári $(p=0,52)$ és a téli csapadékmennyiségek $(p=0,99)$ a megfigyelt időszakban szintén nem változtak jelentősen. Ugyanez a helyzet a tenyészidőszak $(p=0,17)$, a virágzás ideje alatt $(p=0,86)$ és az érésidő alatti csapadékmennyiség $(\mathrm{p}=0,14)$ tekintetében. A tenyészidőszak csapadékos napjainak száma 1977 és 2003 között szintén nem változott jelentősen $(p=0,48)$. A csapadékra vonatkozó eredményeket a 18. táblázatban foglaltuk össze.

18. táblázat: Csapadékindikátorok átlag és szórás eredményei a 1977-2003-as megfigyelt időszakra, illetve a RegCM3 regionális klímamodell 1961-1990-es, 2021-2050-es és a 20712100-as becsült meteorológiai adataira alapozva

\begin{tabular}{|c|c|c|c|c|c|c|c|c|}
\hline \multirow{2}{*}{$\begin{array}{l}\text { Csapadék- } \\
\text { indikátorok }\end{array}$} & \multicolumn{2}{|c|}{$1977-2003$} & \multicolumn{2}{|c|}{ 1961-1990 } & \multicolumn{2}{|c|}{$2021-2050$} & \multicolumn{2}{|c|}{$2071-2100$} \\
\hline & átlag & szórás & átlag & szórás & átlag & szórás & átlag & szórás \\
\hline $\begin{array}{l}\text { Éves csapadék- } \\
\text { menny. }(A R) \\
{[\mathrm{mm}]}\end{array}$ & $474 a$ & 107 & $628 \mathrm{~b}$ & 96 & $583 \mathrm{~b}$ & 112 & $614 \mathrm{~b}$ & 123 \\
\hline $\begin{array}{l}\text { Nyári csapadék- } \\
\text { menny. (SR) } \\
\text { [mm] }\end{array}$ & $108 \mathrm{c}$ & 41 & $96 \mathrm{ab}$ & 39 & $92 \mathbf{a b}$ & 47 & $73 a$ & 38 \\
\hline $\begin{array}{l}\text { Téli csapadék- } \\
\text { menny. (WR) } \\
\text { [mm] }\end{array}$ & $160 a$ & 48 & $275 \mathrm{~b}$ & 62 & $236 \mathrm{~b}$ & 72 & $270 \mathrm{~b}$ & 77 \\
\hline $\begin{array}{l}\text { Tenyészidö } \\
\text { csapadékmenny. } \\
(G S R)[\mathrm{mm}]\end{array}$ & $317 \mathbf{a}$ & 84 & 346 a & 84 & 344 a & 96 & 339 a & 80 \\
\hline $\begin{array}{l}\text { Virágzáskori } \\
\text { csapadékmenny. } \\
(B P R)[\mathrm{mm}]\end{array}$ & $61 \mathrm{a}$ & 37 & $48 \mathrm{a}$ & 21 & $55 a$ & 30 & $46 a$ & 30 \\
\hline $\begin{array}{l}\text { Érésidó" } \\
\text { csapadékmenny. } \\
(R P R)[\mathrm{mm}]\end{array}$ & $79 a$ & 39 & 94 a & 36 & $107 \mathbf{a}$ & 51 & $106 \mathrm{a}$ & 52 \\
\hline $\begin{array}{l}\text { Tenyészidö } \\
\text { csapadékos } \\
\text { napjainak sz. } \\
\text { (GSRD) [nap] }\end{array}$ & $60 a$ & 10 & $92 \mathrm{~d}$ & 12 & $84 \mathrm{c}$ & 12 & $75 \mathrm{~b}$ & 12 \\
\hline
\end{tabular}

A különböző betük szignifikánsan különböző értékeket jelölnek $\mathrm{p}<0,05$ szinten.

Az éves csapadékmennyiség-adatok (AR) 1977 és 2003 között a legtöbb esetben a magyarországi 500-800 mm átlagmennyiséget sem érték el. Az éves átlagos csapadékmennyiség ebben az időszakban 474 mm volt. A legtöbb csapadékot a modellünk az 1961-1990-es évekre 
becsülte, átlagosan $628 \mathrm{~mm}-\mathrm{t}(\mathrm{p}<0,001)$. A jövőre vonatkozóan pedig több csapadékot prognosztizál, mint 1977 és 2003 között. A 2021-2050 közötti időszakra átlagosan 583 mm-t ( $\mathrm{p}<0,001), 2071-2100$-ra átlagosan 614 mm-t $(\mathrm{p}<0,001)$. Ezek szignifikáns emelkedést jeleznek ugyan, de ez csupán egy éves átlagos adat, amit további részekre kell bontanunk, a tények pontosabb megismeréséhez.

Hiába hullik ugyanis átlagos, netán átlagon felüli csapadékmennyiség egy évben, nem mindegy, hogy ennek zöme a vegetációs periódusban, vagy esetleg a nyugalmi időszakban esik. Erre a kérdésre adnak választ a nyári $(S R)$ és a téli csapadékmennyiség $(W R)$, a tenyészidőszak csapadékmennyisége $(G S R)$, a virágzás $(B P R)$ és az érés ideje alatti csapadékmennyiség $(R P R)$ indikátorok, valamint a csapadékos napok száma a tenyészidőszakban (GSRD).

A vegetációs időben átlagon felüli csapadékmennyiség és annak az érés idejében való tömeges lehullása akadályozza a szőlő jó beérését, és rothadási kárt okozhat. Ha a tenyészidő eleje csapadékos és meleg, veszélyezteti a termést a peronoszpóra és a szürkerothadás (Kozma, 1991).

A nyári csapadékmennyiség-adatok átlagértékei közül a megfigyelt időszaké a legnagyobb, 108 mm. Változása a 27 év alatt nem szignifikáns ( $\mathrm{p}=0,52)$. Az 1961-1990-re becsült átlagos csapadékmennyiség 96 mm, mely szignifikánsan kevesebb a megfigyeléseknél $(\mathrm{p}<0,05)$. 20212050-es idősorra a modell $92 \mathrm{~mm}$ átlagos csapadékmennyiséget jósol $(\mathrm{p}<0,05), 2071-2100$-ra pedig már csak 72 mm-t, ami már szignifikáns csökkenést mutat $(\mathrm{p}<0,01)$. Vagyis hiába prognosztizált a modell valamivel több éves csapadékmennyiséget, ennek jelentős része a jövőben várhatóan a tenyészidőszakon kívül, azaz föleg a téli hónapokban fog lehullani.
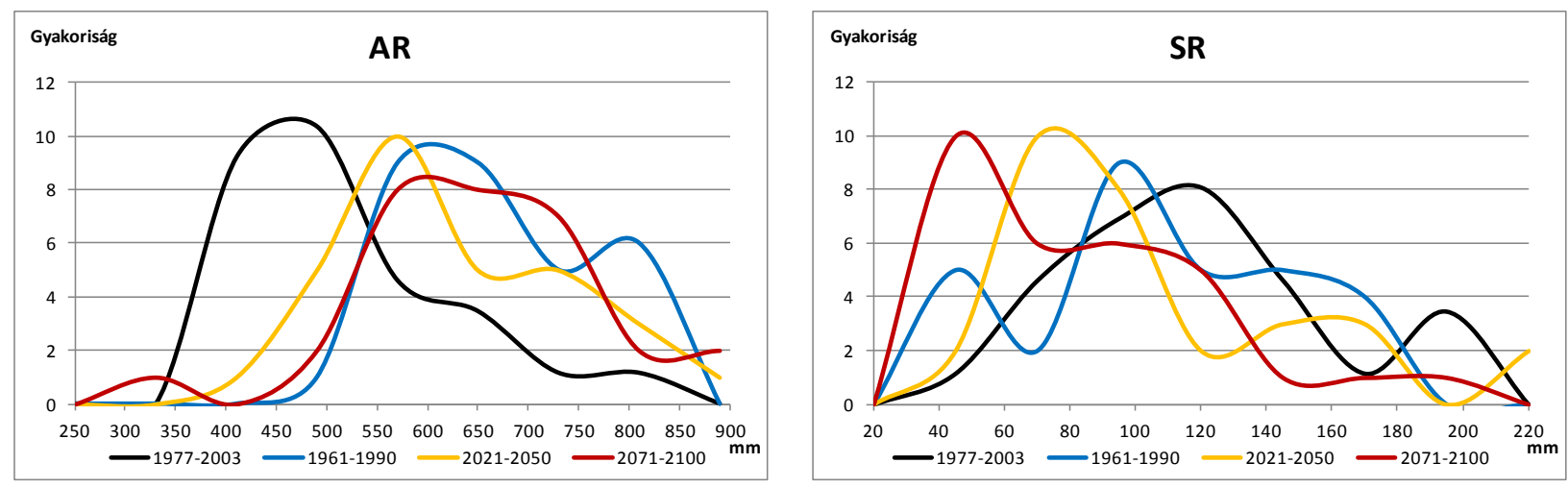

34. ábra: Az éves $(A R)$ és a nyári csapadékmennyiség $(S R) 30$ évre vetített gyakorisági hisztogramjai az 1977-2003-ig terjedő megfigyelt adatok esetén és a RegCM3.1 klímamodell 1961-1990-es referencia-időszakára, valamint a 2021-2050-es és 2071-2100-as időszeletekre

Ezt a jóslatot erősíti a téli csapadékmennyiségek értékeinek növekedése a 2021-2050-es és a 2071-2100-as időintervallumokban, a megfigyelt időszakhoz képest (35. ábra). 1977 és 2003 között átlagosan $160 \mathrm{~mm}$ téli csapadékmennyiséget mértek Kecskeméten. A 27 év alatt nem történt szignifikáns változás az egyes évek átlagértékeit figyelembe véve a mennyiség 
szempontjából ( $\mathrm{p}=0,99)$. A becsült, 1961-1990-es időszakban a téli csapadékmennyiség $275 \mathrm{~mm}$ (p<0,001). 2021-2050-re $236 \mathrm{~mm}$ jelzett a modell $(\mathrm{p}<0,001)$ és 2071-2100-ra $270 \mathrm{~mm}-\mathrm{t}$ $(\mathrm{p}<0,001)$. A változás csak a megfigyelt időszakhoz képest szignifikáns ( $\mathrm{p}<0,001)$. Ha az 19611990-es időszakot hasonlítjuk össze a 2021-2050-nel, akkor nem szignifikáns a változás ( $\mathrm{p}=0,077)$. Az 1961-1990-es időszakot összehasonlítva a 2071-2100-zal, nem szignifikáns a változás $\quad(p=0,969)$. Ugyanígy a 2021-2050-es évek és a 2071-2100-as évek csapadékmennyiségei egymáshoz képest nem mutatnak szignifikáns változást $(p=0,204)$.

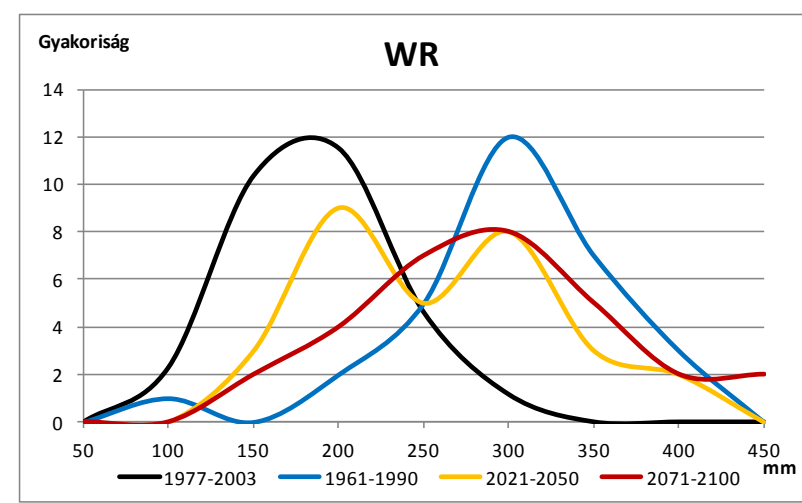

35. ábra: A téli csapadékmennyiségek (WR) 30 évre vetített gyakorisági hisztogramjai az 19772003-ig terjedő megfigyelt adatok esetén és a RegCM3.1 klímamodell 1961-1990-es referenciaidőszakára, valamint a 2021-2050-es és 2071-2100-as időszeletekre

1977 és 2003 között, az összes vegetációs periódus átlagos csapadékmennyisége 317 mm volt ( $\mathrm{p}=0,17,36$. ábra). 1961-1990-re becsült átlagérték $346 \mathrm{~mm}(\mathrm{p}=0,20)$. 2021-2050-re 344 mm-t ( $\mathrm{p}=0,27), 2071-2100-r a 339$ mm-t $(\mathrm{p}=0,32)$ jelez a modell. Vagyis az adott paraméterekkel rendelkező éghajlati modell szerint több csapadékban nem igen reménykedhetünk a tenyészidőszak során, nincs szignifikáns változás egyik irányban sem.

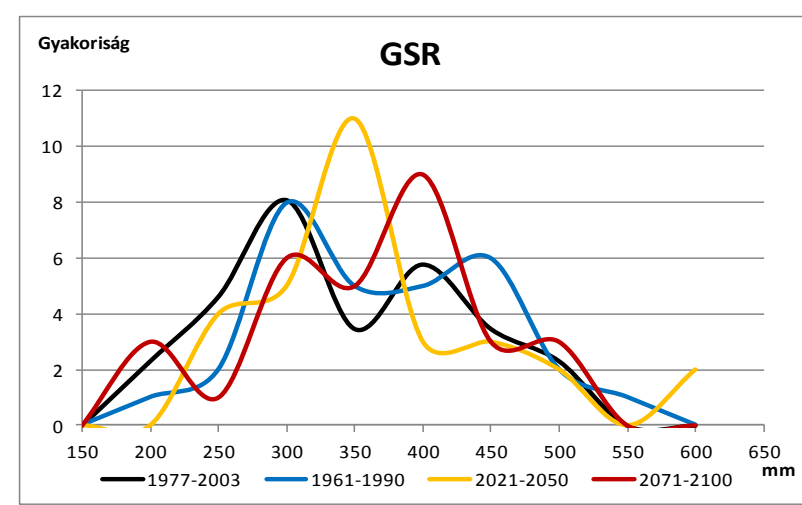

36. ábra: A tenyészidőszakban hullott csapadékmennyiség $(G S R) 30$ évre vetített gyakorisági hisztogramjai az 1977-2003-ig terjedő megfigyelt adatok esetén és a RegCM3.1 klímamodell 1961-1990-es referencia-időszakára, valamint a 2021-2050-es és 2071-2100-as időszeletekre

A virágzáskor $(B P R)$ és az érés alatt hullott csapadékmennyiség $(R P R)$ fontos tényezője a megfelelően kötődött fürtök és a jó, netán kiváló minőségü termés kialakulásának. A megfigyelt időszakban, a 27 év alatt átlagosan $62 \mathrm{~mm}$ csapadék hullott a virágzás során ( $\mathrm{p}=0,86,37$. ábra). 
Az 1961 és 1990 közötti átlagot 48 mm-re becsültük ( $p=0,12)$. A klímamodell szerint 2021 és 2050 között ez 55 mm lesz átlagosan (p=0,51), és 2071 és 2100 között 46 mm-es átlagra csökken $(\mathrm{p}=0,10)$, szignifikáns változás tehát nem várható.
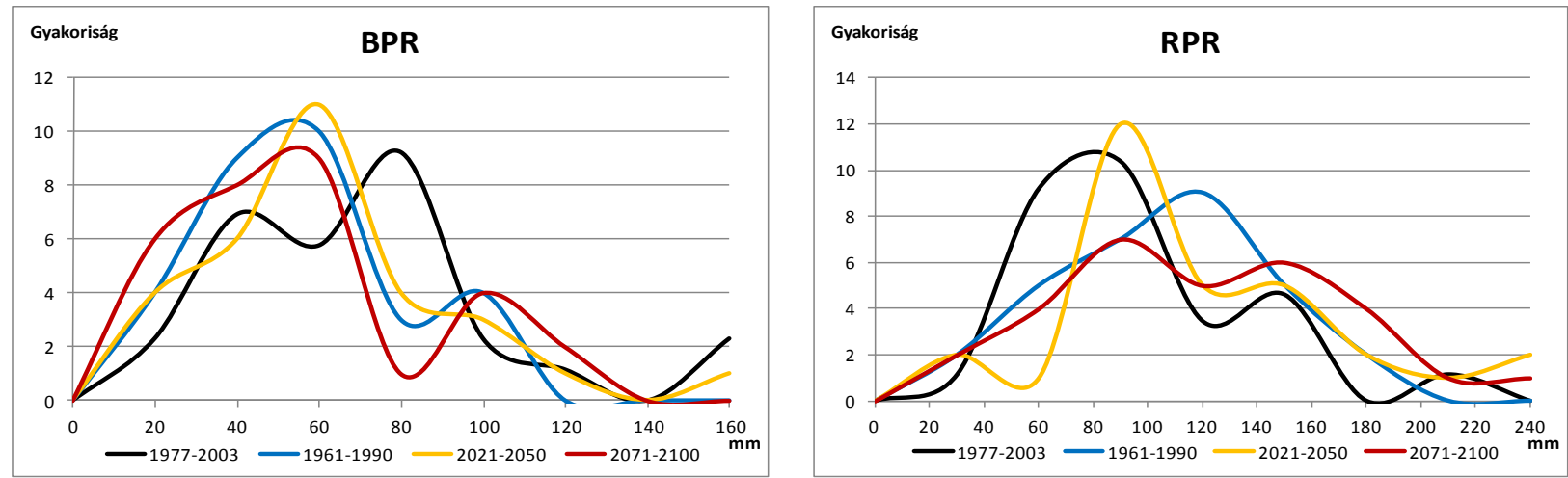

37. ábra: A virágzási $(B P R)$ és érési időszakban hullott csapadékmennyiség $(R P R) 30$ évre vetített gyakorisági hisztogramjai az 1977-2003-ig terjedő megfigyelt adatok esetén és a RegCM3.1 klímamodell 1961-1990-es referencia-időszakára, valamint a 2021-2050-es és 20712100-as idöszeletekre

Az érés ideje alatti átlagos csapadékmennyiség $(R P R)$ esetében viszont ennek ellenkezőjét tapasztaltuk. 1961-1990 közötti időszakra a modell átlagosan 94 mm-t becsült ( $\mathrm{p}=0,147)$, az 1977-2003-as megfigyelt időszakra vonatkozó átlagérték 79 mm (p=0,612), ami csökkenést mutat a korábbi évekhez képest. 2021-2050-re ez az érték átlagosan már 107 mm ( $\mathrm{p}=0,108)$, 2071-2100-ra 106 mm (p=0,138), tehát a változás nem szignifikáns.

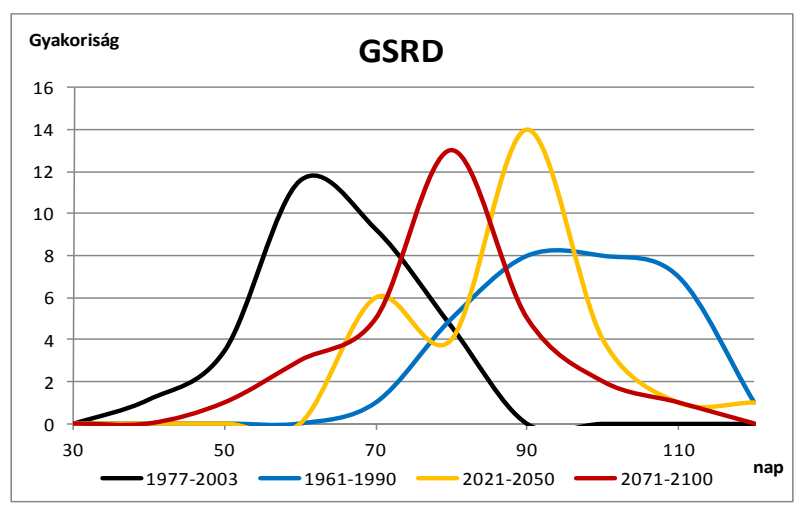

38. ábra: A tenyészidőszak csapadékos napjainak (GSRD) 30 évre vetített gyakorisági hisztogramjai az 1977-2003-ig terjedő megfigyelt adatok esetén és a RegCM3.1 klímamodell 1961-1990-es referencia-időszakára, valamint a 2021-2050-es és 2071-2100-as időszeletekre

A tenyészidőszakok csapadékos napjainak átlagos számát (GSRD) az 1977-2003-as megfigyelt időszakra, az 1961-1990-es becsült időszakra és az előrejelzéseket 2021-2050-re, valamint 2071-2100-ra a 18. táblázat utolsó sorában foglaltuk össze (38. ábra). A referenciaidőszakra, valamint a jövőre becsült adatok minden összehasonlításban szignifikáns csökkenést mutatnak $(\mathrm{p}<0,05)$. A megfigyelések (1977-2003) átlaga mindhárom, a modell által becsült időszak átlagánál szignifikánsan alacsonyabb $(\mathrm{p}<0,001)$. 
Mindez azt jelenti, hogy várhatóan kevesebb idő alatt hullik le nagyjából ugyanannyi csapadék, és így a jövőben megnövekszik a peronoszpórás és botrytises megbetegedések várható gyakorisága, növekedhet a védekezésre fordított költség, illetve elötérbe kerülhet a rezisztens fajták telepítése.

\subsection{Tenyészidő számítási módszerek kritikai összehasonlítása}

A tenyészidőszakok hosszának meghatározásához kétféle módszert használtam. Az első módszer esetében a vegetációs periódust a tavaszi $+10^{\circ} \mathrm{C}$-os középhőmérséklet beállásától a +10 ${ }^{\circ} \mathrm{C}$-os középhőmérsékletű napok megszünéséig számítjuk (Kozma, 1991). A másik módszer a szőlőtermesztésben alkalmazott interpolációs módszer. A 21. mellékletben a helvéciai adatokból számított tenyészidőszakok láthatóak, míg a 22. mellékletben a kecskeméti termőhely periódusait foglaltam össze.

A kétféle számítási módszer között $t$-próbával szignifikáns eltéréseket tudtam igazolni (19. táblázat). 1987-ben az I. módszer szerint május 24-én kezdődött a tenyészidőszak, míg az interpolációs módszerrel számítva ez a nap április 11-ére esett. Az is látható, hogy az interpolációs módszer az első módszerhez képest szisztematikusan korábbi tenyészidőszakkezdetet ad eredményül. Ugyanilyen szisztematikus különbség a két módszer között a tenyészidőszak végének számítására vonatkozóan nem mondható el.

19. táblázat: A kétféle tenyészidőszak számítási módszer (I. és II.) statisztikai összehasonlítása mindkét idősorra

\begin{tabular}{|c|c|c|c|c|c|c|c|}
\hline Évek & Módszer & $\begin{array}{c}\text { T.i. } \\
\text { eleje_JN }\end{array}$ & $\mathrm{p}$ & $\begin{array}{c}\text { T.i. } \\
\text { vége } J N\end{array}$ & $\mathrm{p}$ & $\begin{array}{c}\text { T.i. } \\
\text { hossza_JN }\end{array}$ & $\mathrm{p}$ \\
\hline \multirow{2}{*}{$\begin{array}{l}1977- \\
2003\end{array}$} & I. & 119,04 & \multirow{2}{*}{$\mathrm{p}<0,001$} & 296,22 & \multirow{2}{*}{$\mathrm{p}=0,58$} & 177,2 & \multirow{2}{*}{$\mathrm{p}<0,001$} \\
\hline & II. & 97,44 & & 298,22 & & 200,9 & \\
\hline \multirow{2}{*}{$\begin{array}{l}2000- \\
2004\end{array}$} & I. & 111,4 & \multirow{2}{*}{$\mathrm{p}<0,05$} & 284,6 & \multirow{2}{*}{$\mathrm{p}<0,05$} & 173,2 & \multirow{2}{*}{$\mathrm{p}<0,05$} \\
\hline & II. & 98 & & 310 & & 212 & \\
\hline \multirow{2}{*}{ Együtt } & I. & 117,84 & \multirow{2}{*}{$\mathrm{p}<0,001$} & 294,41 & \multirow{2}{*}{$\mathrm{p}=0,126$} & 176,56 & \multirow{2}{*}{$\mathrm{p}<0,001$} \\
\hline & II. & 97,53 & & 300,19 & & 202,66 & \\
\hline
\end{tabular}

T.i.=tenyészidő; $\mathrm{JN}=$ Julianus nap

Ha a megfigyelt rügyfakadási adatokat a számított tenyészidőszakokkal összevetjük, látható, hogy 2004-ben Helvécián az I. módszerrel meghatározott tenyészidőszak kezdete előtt történt meg a rügyfakadás (23-25. melléklet). A pontatlanság eredhet a szélsőséges hőmérsékleti értékekből, amit 2004-ben a késő tavaszi fagyok okoztak. A fentieket figyelembe véve az interpolációs módszer sokkal jobb becslésnek mondható, mint az első módszer. Mindazonáltal az interpolációs módszer is inkább terroárok összehasonlítására javasolt, kiemelve a módszernek azt az előnyét, hogy egyszerü és széles körben általánosan alkalmazható. Mindazonáltal a klímaváltozással várható egyre gyakoribb szélsőségek miatt a tenyészidőszaknak ez a fajta számítási módja pontosabb becslést igénylő esetekben (pl. fenológiai következtetések 
levonására) egyre kevésbé lesz használható. Ez is indokolja a fenológiai modellek használatának egyre növekvő szükségességét.

A tenyészidőszak számítási módszerek összehasonlítását páros $t$-próbával is elvégeztem. A különbségminták normalitása Kolmogorov-Smirnov próbával és Shapiro-Wilk teszttel igazolható $(\mathrm{p}>0,05)$.

\subsection{Egyszerü hőösszeg modell a rügyfakadás idejének becslésére}

Először a 2000 és 2004 között felvételezett helvéciai rügyfakadás adatokat használtuk fel egy egyszerü hőösszeg modell futtatásához. Az optimális bázishőmérséklet $6{ }^{\circ} \mathrm{C}$, az optimális induló nap a 41. az évben (febr. 10-e, a statisztikailag számított mélynyugalom vége, a kényszernyugalom kezdete). A 20. táblázatban jól láthatóak az egyes fajták és klónjaik rügyfakadásig összegyült hőösszegei ${ }^{\circ} \mathrm{C}$-ban. Ezek az értékek megfelelnek a szakirodalomban fellehető, fiziológiai megfontolásokon alapuló értékeknek. A táblázatból az is kitűnik, hogy még a klónok hőösszeg igényei között is lehetnek eltérések. Látható továbbá, hogy a rügyfakadáshoz a fajtáknak a legkevesebb hőösszegre 2003-ban volt szükségük, 2004-ben pedig a legtöbbre.

20. táblázat: A 2000-től 2004-ig megfigyelt, illetve az ezek átlagából számított kritikus hőösszeg értékek a különböző fajtákra

\begin{tabular}{|c|c|c|c|c|c|c|c|c|c|c|c|c|c|c|c|c|}
\hline $\begin{array}{c}\text { Fajták } \\
\text { Évek }\end{array}$ & Ch & Ch_75 & Ch_96 & Szb & Szb_34 & Szb_52 & Pb_54 & Pb_55 & Pb_D55 & Rr_239 & Rr_378 & Rr_391 & $\mathrm{Rr}_{4} 49$ & HI_P41 & HI_K9 & Átlag \\
\hline 2000 & 199,45 & 199,45 & 229,65 & 283,55 & 283,55 & 283,55 & 229,65 & 283,55 & 283,55 & 283,55 & 283,55 & 283,55 & 283,55 & 283,55 & 283,55 & 221,32 \\
\hline 2001 & 256,50 & 271,20 & 256,50 & 291,15 & 280,30 & 303,75 & 246,40 & 256,50 & 256,50 & 291,15 & 303,75 & 303,75 & 303,75 & 291,15 & 291,15 & 225,05 \\
\hline 2002 & 263,80 & 263,80 & 270,90 & 313,90 & 313,90 & 326,00 & 263,80 & 270,90 & 253,70 & 278,50 & 286,60 & 286,60 & 296,20 & 286,60 & 286,60 & 219,53 \\
\hline 2003 & 195,20 & 195,20 & 195,20 & 218,90 & 237,50 & 218,90 & 218,90 & 218,90 & 206,80 & 218,90 & 218,90 & 218,90 & 218,90 & 218,90 & 206,80 & 177,40 \\
\hline 2004 & 262,00 & 271,60 & 271,60 & 245,80 & 271,60 & 262,00 & 252,90 & 331,60 & 271,60 & 331,60 & 319,00 & 319,00 & 271,60 & 294,30 & 262,00 & 233,57 \\
\hline Átlag & 235,39 & 240,25 & 244,77 & 270,66 & 277,37 & 278,84 & 242,33 & 272,29 & 254,43 & 280,74 & 282,36 & 282,36 & 274,80 & 274,90 & 266,02 & \\
\hline
\end{tabular}

Fajtánként elemezve a 21. tábázatot, kiderül, hogy a Chardonnay fajta rügyfakadását lehet a legnehezebben pontosan megjósolni (3,2 nap átlagos abszolút hiba). A legkisebb átlagos abszolút hibát a Rajnai rizling 49 és a Pinot blanc 54 klónok esetében (1,2 nap) hozta a modell becslése. A többi fajtánál és klónnál általában két nap körül mozog az eltérés, ami közelít a becslés átlagos hiba értékéhez (2,07 nap). A legjobban becsülhető év a 2000. volt, míg a legnagyobb hibával a 2003. járt.

21. táblázat: A rügyfakadás becslések eltérései a megfigyelt adatokhoz képest

\begin{tabular}{|c|c|c|c|c|c|c|c|c|c|c|c|c|c|c|c|c|}
\hline $\begin{array}{c}\text { Fajták } \\
\text { Évek }\end{array}$ & $\mathrm{Ch}$ & Ch_75 & Ch_96 & Szb & Szb_34 & Szb_52 & Pb_54 & Pb_55 & Pb_D55 & Rr_239 & Rr_378 & Rr_391 & Rr_49 & HI_P41 & HI_K9 & $\begin{array}{c}\text { Az } \\
\text { abszolút- } \\
\text { értékek } \\
\text { éves } \\
\text { átlaga }\end{array}$ \\
\hline 2000 & 3 & 3 & 2 & 0 & 0 & 0 & 2 & 0 & -2 & 0 & 0 & 0 & 0 & 0 & -1 & 0,87 \\
\hline 2001 & -3 & -4 & -1 & -2 & 0 & -2 & 0 & 3 & 0 & 0 & -1 & -1 & -2 & -1 & -2 & 1,47 \\
\hline 2002 & -2 & -2 & -2 & -5 & -4 & -4 & -1 & 1 & 1 & 1 & 0 & 0 & -2 & -1 & -2 & 1,87 \\
\hline 2003 & 3 & 4 & 4 & 4 & 3 & 4 & 2 & 4 & 4 & 4 & 5 & 5 & 4 & 4 & 4 & 3,87 \\
\hline 2004 & -3 & -3 & -3 & 3 & 1 & 2 & -1 & -4 & -1 & -4 & -3 & -3 & 1 & -1 & 1 & 2,27 \\
\hline $\begin{array}{c}\text { Az } \\
\text { abszolút- } \\
\text { értékek } \\
\text { átlaga }\end{array}$ & 2,80 & 3,20 & 2,40 & 2,80 & 1,60 & 2,40 & 1,20 & 2,40 & 1,60 & 1,80 & 1,80 & 1,80 & 1,20 & 1,40 & 2,00 & 2,07 \\
\hline
\end{tabular}

Modellünk becslésének jellemzőit a 39. ábrán illusztráltuk. Láthatjuk, hogy ha a bázishőmérséklet rögzített $\left(6^{\circ} \mathrm{C}\right.$-on), a háromféle hiba (standard hiba, a hiba átlagos abszolút 
értéke és a maximális abszolút hiba) mindegyike minimális, ha az indulási időpont az év 41. napja. Ha az induló nap (41. Julianus nap) rögzített, akkor a három hibatípus a legkisebb, ha a bázishőmérséklet $6^{\circ} \mathrm{C}$-ra van beállítva. A modell az induló napra a legérzékenyebb.

Az átlagos abszolút különbség a megfigyelt és előre jelzett időpontok között 2,07 nap volt, a maximális hiba 5 nap.
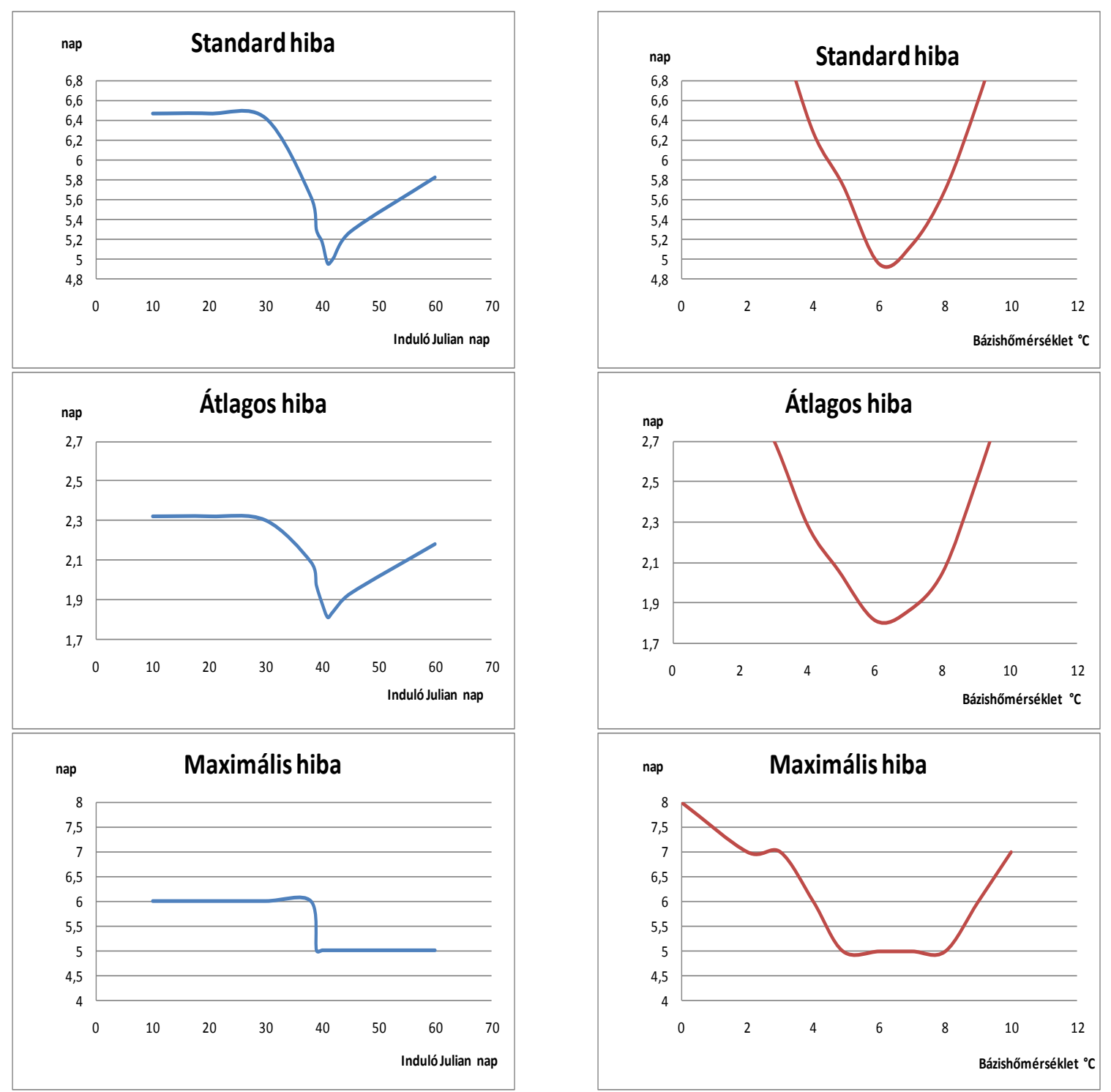

39. ábra: A becslések optimális tulajdonságai a standard hiba, a hibák abszolút értékeinek átlaga, valamint maximuma alapján, rögzített bázishőmérsékletre $\left(6^{\circ} \mathrm{C}\right)$ és változó induló napra, illetve rögzített induló nap mellett (41. Julianus nap, azaz február 10-e), változó bázishőmérsékletre

A különbözö fajtacsoportokra vonatkozó megfigyelt (o) és becsült (p) rügyfakadási időpontokat ábrázolva láthatjuk, hogy a Chardonnay fajták rügyfakadásának előrejelzésében igen nagy a változatosság (40. ábra). A legnagyobb eltérések a Rajnai rizling klónoknál és a Szürkebarát fajtánál vannak (5 nap). A 2000. év rügyfakadásait igen kis hibával, a 2001. és 2002. években kis hibával sikerült megbecsülni minden fajtára és klónra.

A Pinot blanc fajta klónsorozatnál az 54-es klón esetében a legkisebb a modell hibája, 
azaz 0 és 2 nap között mozog az öt év adatait vizsgálva (21. táblázat). A másik két klón, az 55 és D55 rügyfakadás elörejelzésének becsült hibái közel azonos értékek körül mozognak. A Rajnai rizling fajtáknál 2000-ben teljesen fedik egymást a mért és a becsült rügyfakadási adatok, a 21. táblázatban látható, hogy a becslés hibája mind a négy fajta esetében 0 nap. 2001ben és 2002-ben már kis eltérések vannak, 2003-ben a modell négy napot késik, majd 2004-ben 3-4 nappal korábban jelez, mint a valós rügyfakadás. A Rajnai rizling 378 és 391 klónoknak a rügyfakadás időpontja a mért adatok alapján teljesen szinkronban van egymással. A Rajnai rizling 49 kissé eltér a többitől.
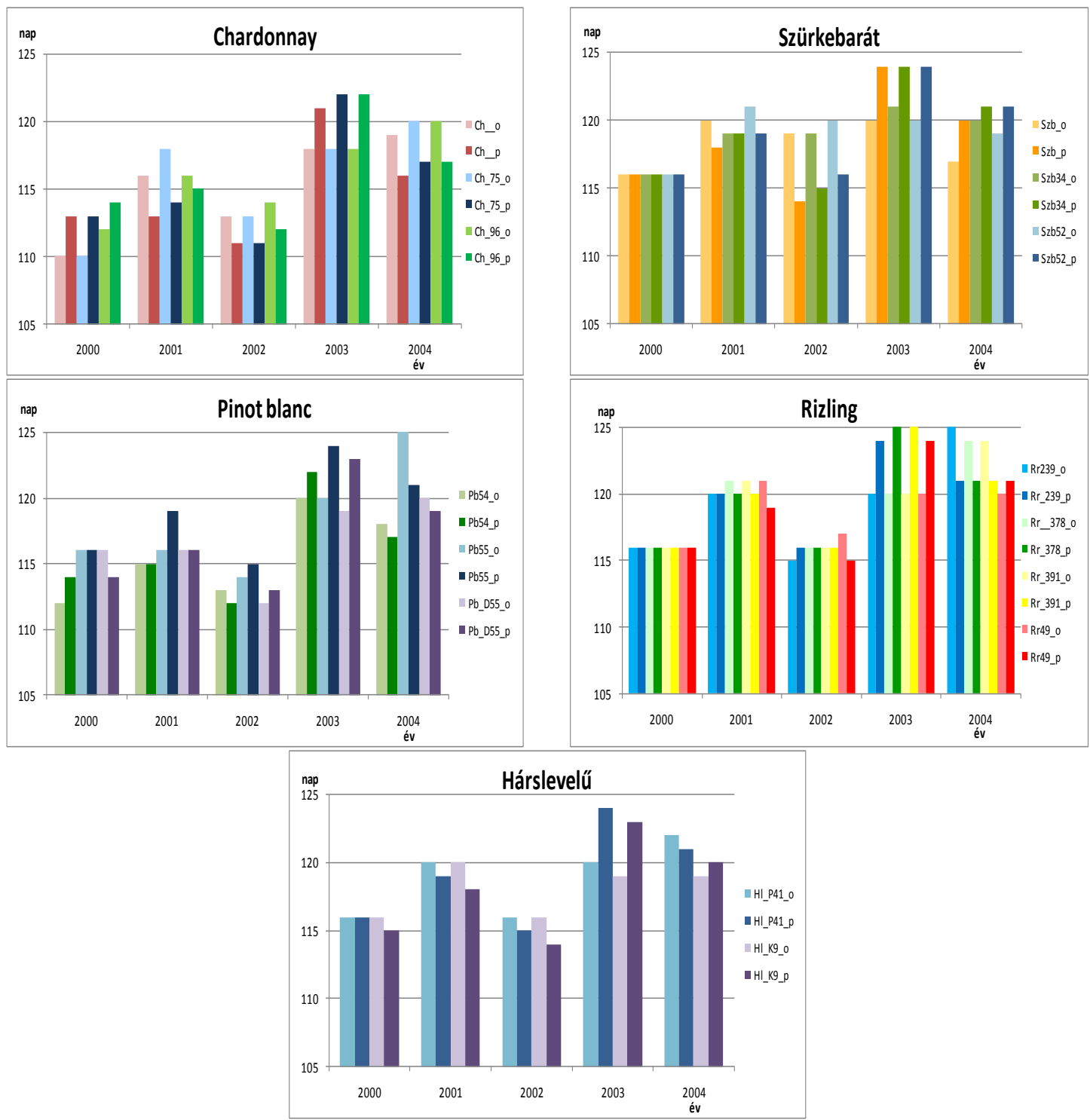

40. ábra: A vizsgált fajták és klónjaik megfigyelt (o) és a modellünk által becsült (p) rügyfakadás napjai 2000-2004 (Helvécia)

\subsection{Egyszerü hőösszeg modell a fövirágzás kezdetének idejére}

Az optimális alsó bázis hőmérsékletet $11^{\circ} \mathrm{C}$-ra, a felső bázishőmérsékletet pedig $26^{\circ} \mathrm{C}$-ra kalibráltuk. A 22. táblázat mutatja a különböző fajták kumulált hőösszeg értékeit 2000 és 2004 között. 
22. táblázat: Kumulált megfigyelt höösszegek $\left({ }^{\circ} \mathrm{C}\right)$ a különböző fajtáknál a rügyfakadás és a virágzás között 2000 és 2004 között, valamint ezek átlagértékei

\begin{tabular}{|c|c|c|c|c|c|c|c|c|c|c|c|c|c|c|c|c|}
\hline $\begin{array}{c}\text { Fajták } \\
\text { Évek }\end{array}$ & Ch & Ch_75 & Ch_96 & Szb & Szb_34 & Szb_52 & Pb_54 & Pb_55 & Pb_D55 & Rr_239 & Rr_378 & Rr_391 & Rr_49 & HI_P41 & HI_K9 & Átlag \\
\hline 2000 & 259,55 & 259,55 & 253,00 & 242,95 & 242,95 & 237,90 & 253,00 & 242,95 & 253,00 & 242,95 & 244,50 & 242,95 & 242,95 & 295,25 & 302,80 & 254,42 \\
\hline 2001 & 245,20 & 245,15 & 238,60 & 248,20 & 249,70 & 246,65 & 252,75 & 246,65 & 254,80 & 243,10 & 246,15 & 243,10 & 249,70 & 299,95 & $288,95^{\circ}$ & 253,24 \\
\hline 2002 & 306,15 & 288,50 & 257,80 & 294,05 & 270,80 & 268,75 & 290,00 & 276,85 & 270,35 & 274,80 & 268,75 & 268,75 & 276,85 & 288,45 & $290,00^{\circ}$ & 279,39 \\
\hline 2003 & 247,33 & 234,28 & 234,28 & 204,50 & 212,68 & 212,68 & 234,28 & 212,68 & 226,23 & 212,68 & 206,13 & 206,13 & 212,68 & 204,50 & $218,05^{\circ}$ & 218,60 \\
\hline 2004 & 266,30 & 264,75 & 264,75 & 233,00 & 218,40 & 206,35 & 240,15 & 241,00 & 236,55 & 253,55 & 253,55 & 268,65 & 253,55 & 277,70 & 245,05 & 248,22 \\
\hline Átlag & 264,91 & 258,45 & 249,69 & 244,54 & 238,91 & 234,47 & 254,04 & 244,03 & 248,19 & 245,42 & 243,82 & 245,92 & 247,15 & 273,17 & 268,97 & \\
\hline
\end{tabular}

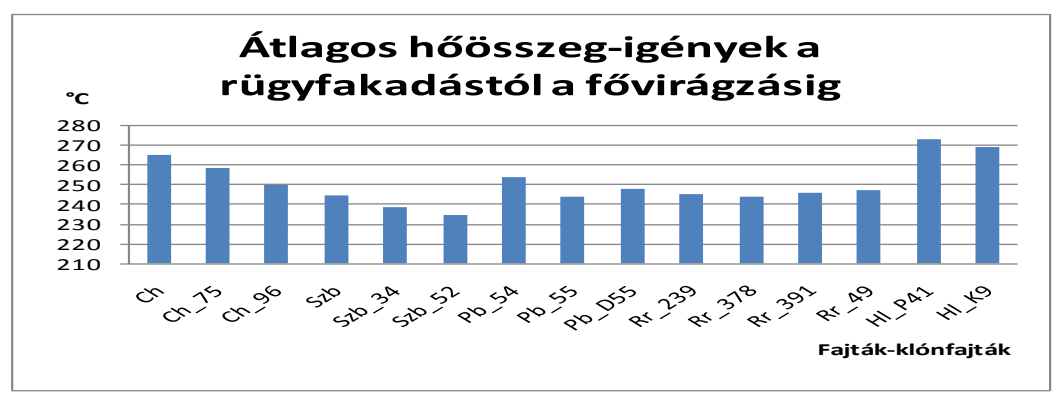

41. ábra: Átlagos hőösszeg-igények a rügyfakadástól a fövirágzásig a 2000-2004-ben Helvécián megfigyelt fenológiai adatok alapján.

Az átlagos kritikus höösszegek az 23. táblázat alsó sorában láthatóak (Az utolsó oszlopban az évenkénti átlagos hőösszeget foglaltuk a 15 fajta esetében). A 41. ábrán látható, hogy a korai érésü Szürkebarát fajtáknak volt a legalacsonyabb a hőösszeg igényük $\left(238,91^{\circ} \mathrm{C}\right.$ és $\left.234,47^{\circ} \mathrm{C}\right)$. A kései érésü Rajnai rizling klónok kritikus hőösszegei $\left(243,82^{\circ} \mathrm{C}-247,15^{\circ} \mathrm{C}\right)$ követik ezeket az értékeket. A Pinot blanc klónok kritikus hőösszeg értékei $244{ }^{\circ} \mathrm{C}$ és $254{ }^{\circ} \mathrm{C}$ között alakultak. A korai érésű Chardonnay és a késői Hárslevelü klónok kritikus hőösszeg értékei lettek a legnagyobbak $\left(249^{\circ} \mathrm{C}-273^{\circ} \mathrm{C}\right)$.

23. táblázat: A fővirágzás-kezdetek becsléseinek eltérései a megfigyelt adatokhoz képest.

\begin{tabular}{|c|c|c|c|c|c|c|c|c|c|c|c|c|c|c|c|c|}
\hline $\begin{array}{c}\text { Fajták } \\
\text { Évek }\end{array}$ & Ch & Ch_75 & Ch_96 & Szb & Szb_34 & Szb_52 & Pb_54 & Pb_55 & Pb_D55 & Rr_239 & Rr_378 & Rr_391 & $R_{\text {r_49 }}$ & HI_P41 & HI_K9 & \begin{tabular}{|c|} 
Az \\
abszolút- \\
értékek \\
éves \\
átlaga \\
\end{tabular} \\
\hline 2000 & 2 & 0 & -1 & 2 & 0 & -1 & 1 & 1 & -1 & 2 & 0 & 2 & 2 & -1 & -2 & 1,07 \\
\hline 2001 & 6 & 5 & 2 & -1 & -3 & -3 & 1 & -1 & -2 & 1 & 0 & 1 & 0 & -2 & -1 & 2,27 \\
\hline 2002 & 5 & -3 & 0 & -7 & -3 & -3 & -4 & -4 & -2 & -3 & -2 & -2 & -3 & -2 & -3 & 3,07 \\
\hline 2003 & 2 & 3 & 2 & 4 & 3 & 2 & 2 & 3 & 2 & 3 & 4 & 4 & 4 & 7 & 5 & 3,20 \\
\hline 2004 & 0 & 0 & -1 & 1 & 2 & 3 & 2 & 1 & 1 & 0 & 0 & -2 & 0 & 0 & 3 & 1,33 \\
\hline $\begin{array}{c}\mathrm{Az} \\
\text { abszolút- } \\
\text { értékek } \\
\text { átlaga }\end{array}$ & 3,00 & 2,20 & 1,20 & 3,00 & 2,20 & 2,40 & 2,00 & 2,00 & 1,60 & 1,80 & 1,20 & 2,20 & 1,80 & 2,40 & 2,80 & 2,12 \\
\hline
\end{tabular}

A modell által becsült értékeknek a megfigyelttől való eltéréseit elemezve láthatjuk, hogy a Chardonnay és a Szürkebarát fajták virágzását volt a legnehezebb megjósolni (23. táblázat). A legtöbb fajta abszolút hibája az átlag körül mozog (2,12 nap), ami mutatja a modell viszonylag magas stabilitását. A modell a legkevesebb hibát a Chardonnay 96 és a Rajnai rizling 378 klónoknál (átlagosan 1,2 nap) vétette.

A 42. ábrán az optimalizált eredmények láthatóak. A bal oszlopban látható, hogy ha a felső bázishőmérsékletet $26^{\circ} \mathrm{C}$-ra rögzítjük, változó alsó bázishőmérséklet mellett a standard hiba 11 ${ }^{\circ} \mathrm{C}$-nál a minimumon van. Ugyanakkor az eltérések legnagyobb és átlagos abszolút értéke $11{ }^{\circ} \mathrm{C}$ nál szintén a minimumon van. 

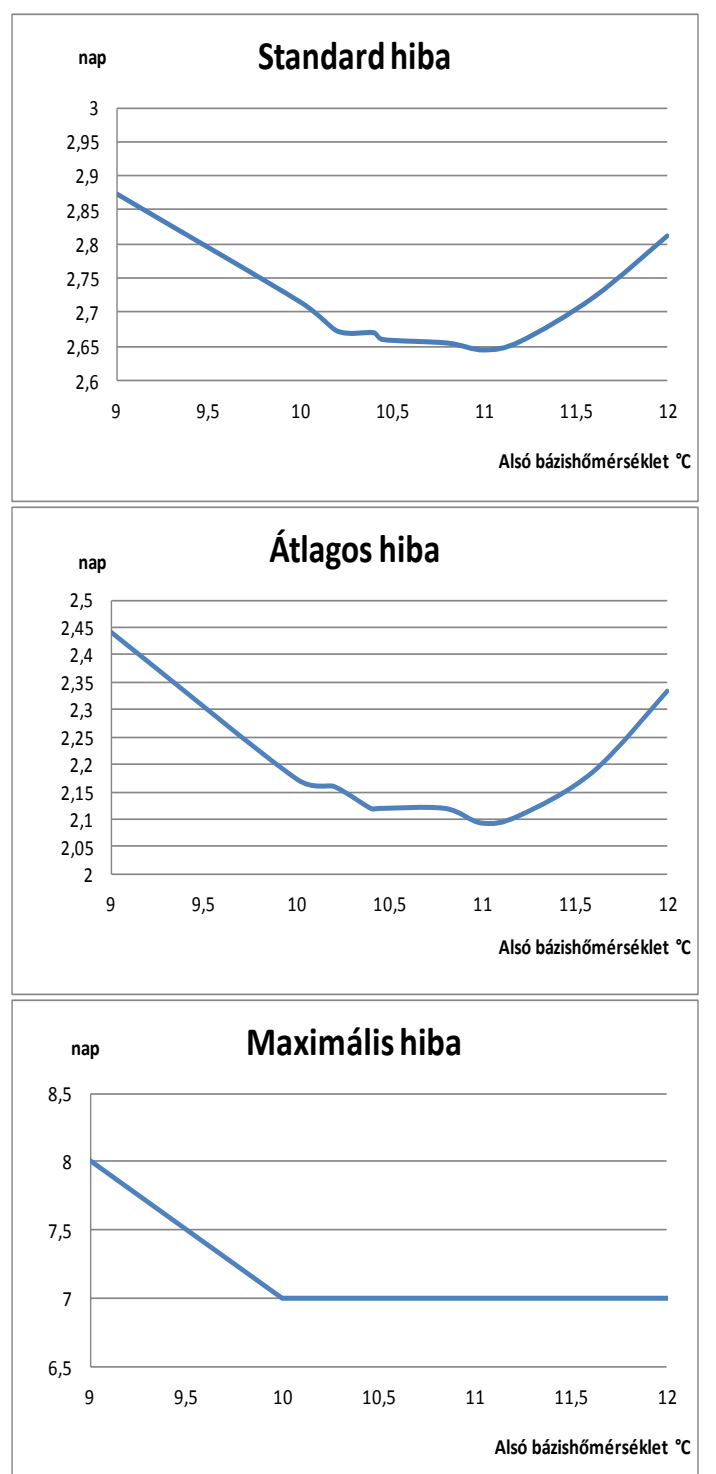
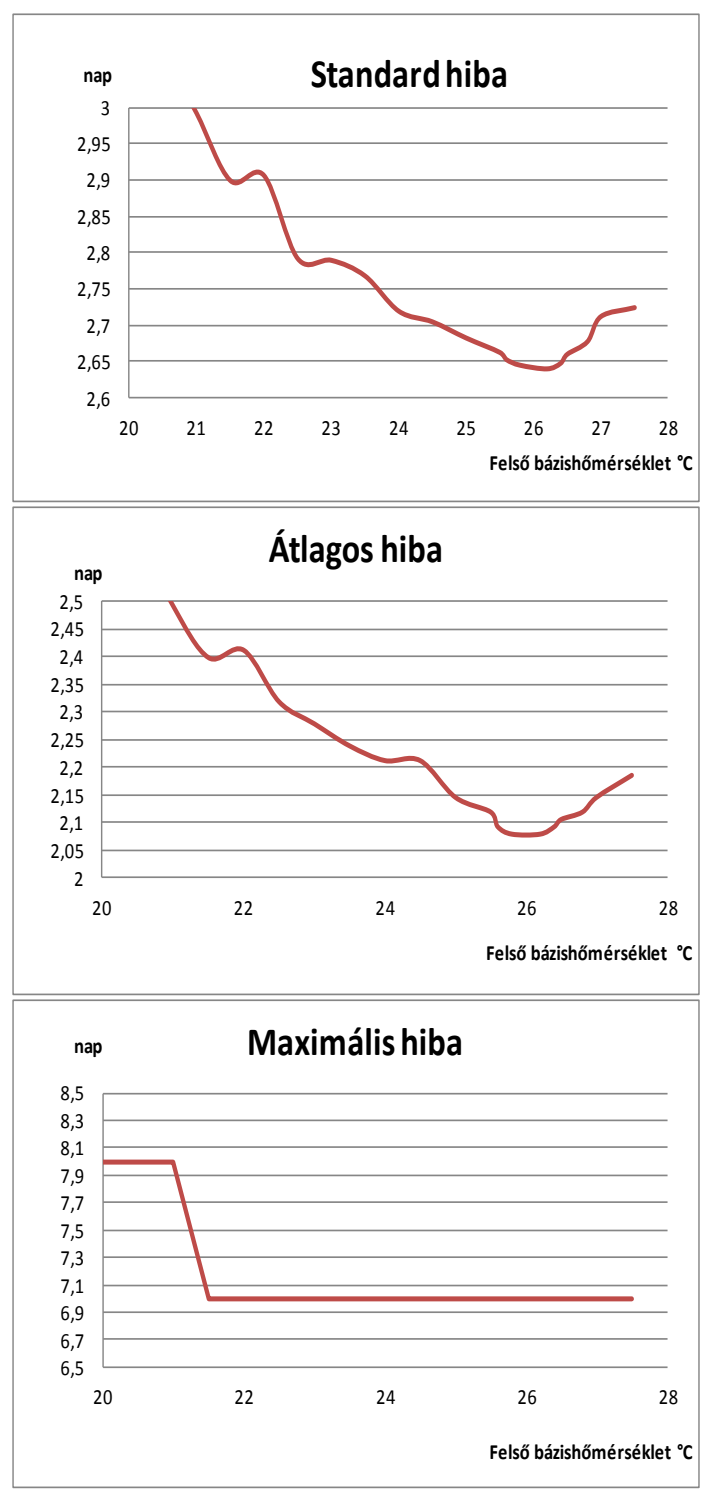

42. ábra: A két paraméter, az alsó és felső bázis hőmérséklet optimális jellemzői; rögzített felső bázis hőmérsékletre $\left(26^{\circ} \mathrm{C}\right)$ és változó alsó bázis hőmérsékletre (baloldal), valamint rögzített alsó bázis hőmérsékletre $\left(11^{\circ} \mathrm{C}\right)$ és változó felső bázishőmérsékletre (jobb oldalon).

Ha az alsó bázishőmérsékletet rögzítjük $11{ }^{\circ} \mathrm{C}$-ra és mozgatjuk a felső bázishőmérsékletet, látjuk, hogy $26^{\circ} \mathrm{C}$-nál mind a három hiba elérte a minimum értékét, következésképp, a felső bázishőmérséklet meghatározása ennél a pontnál optimális (42. ábra, jobb oszlop). A felső bázishőmérséklet érzékenyebb, mint az alsó. A maximális hiba egyik paraméterre sem túl érzékeny.

A következő diagram-összefoglalón (43. ábra) a megfigyelt és a becsült fővirágzás időpontokat mutatjuk. A Chardonnay és klónjai öt évet átívelő diagramjára tekintve jól látható, hogy 2000-ben, 2003-ban és 2004-ben kis hibával vagy pontosan jelzett a modell, a legnagyobb tévedése a Chardonnay fajtánál +6 nap (2001) volt, vagyis hat nap késéssel jelezte a tömeges virágzást. 2001-ben láthatóak a legnagyobb eltérések a megfigyelt és az előre jelzett értékek oszlopdiagramjai között. 


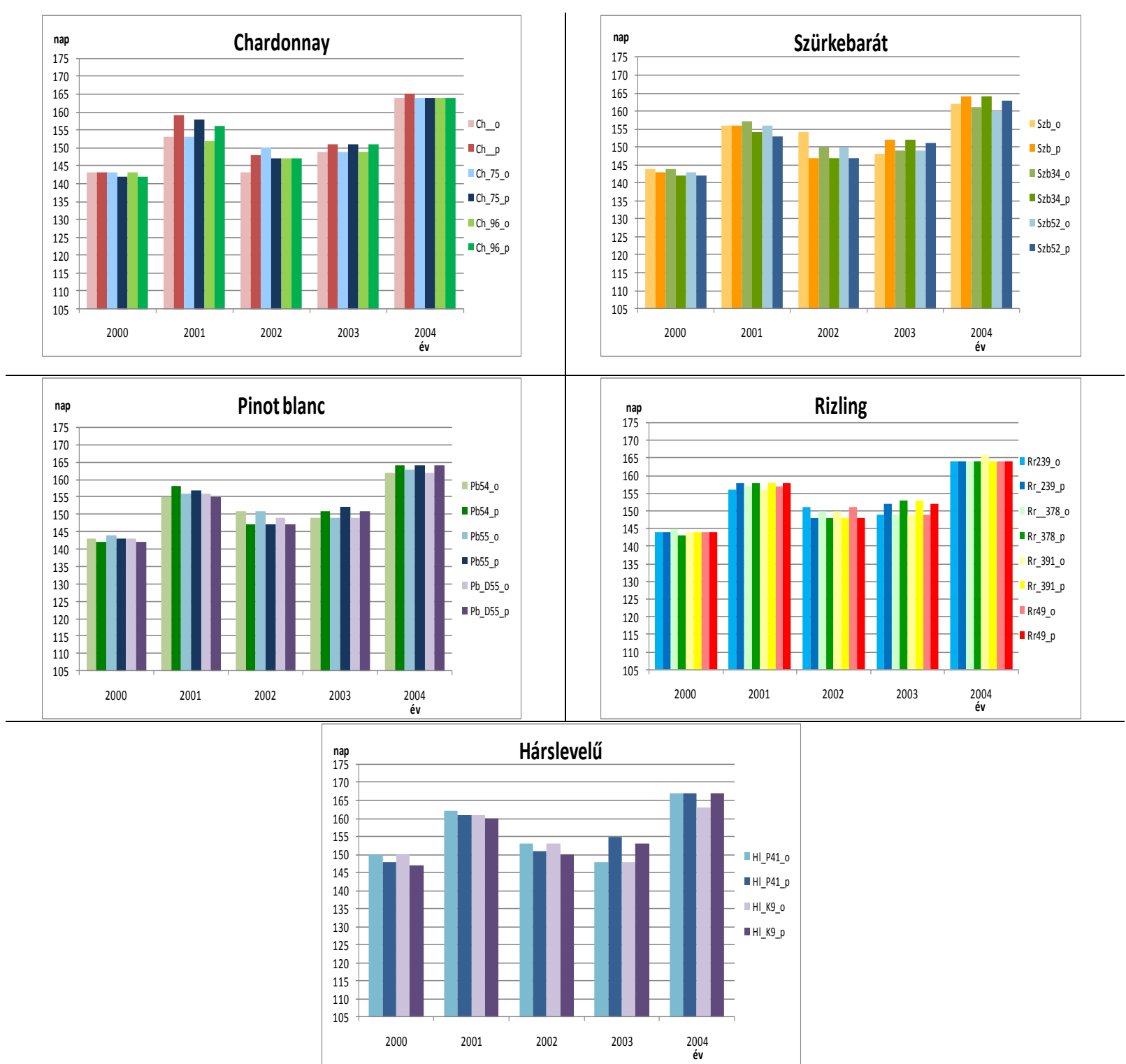

43. ábra: A vizsgált fajták és klónjaik megfigyelt (o) és a modellünk által becsült (p) fővirágzás kezdőnapjai 2000-2004 (Helvécia)

A szintén korai érésű Szürkebarát fajtacsoportra való előrejelzése szintén jó, bár a 2002-es évre a Szürkebarátra korai időpontot jelzett, nagy hibával (a modell maximális hibája). A másik két klón esetében a modell pontosabb, maximum 3 napos hibával.

A Szürkebarát fajta és klónjai értékeivel összehasonlítva a közepes érési idejü Pinot blanc klónok fővirágzásának előrejelzése a diagramok szerint jóval kiegyenlítettebb. A legjobban előrejelezhető év ennél a fajtánál a 2000-es volt, a legkevésbé előrejelezhető a 2002-es, de itt is csak maximum 4 napot tévedett a modell.

A kései érésű Rajnai rizling klónok esetében a modell átlagosan a legkevesebb hibával jelez. Ezekre a klónokra a 2003-as év járt a legnagyobb hibával (4 nap). 


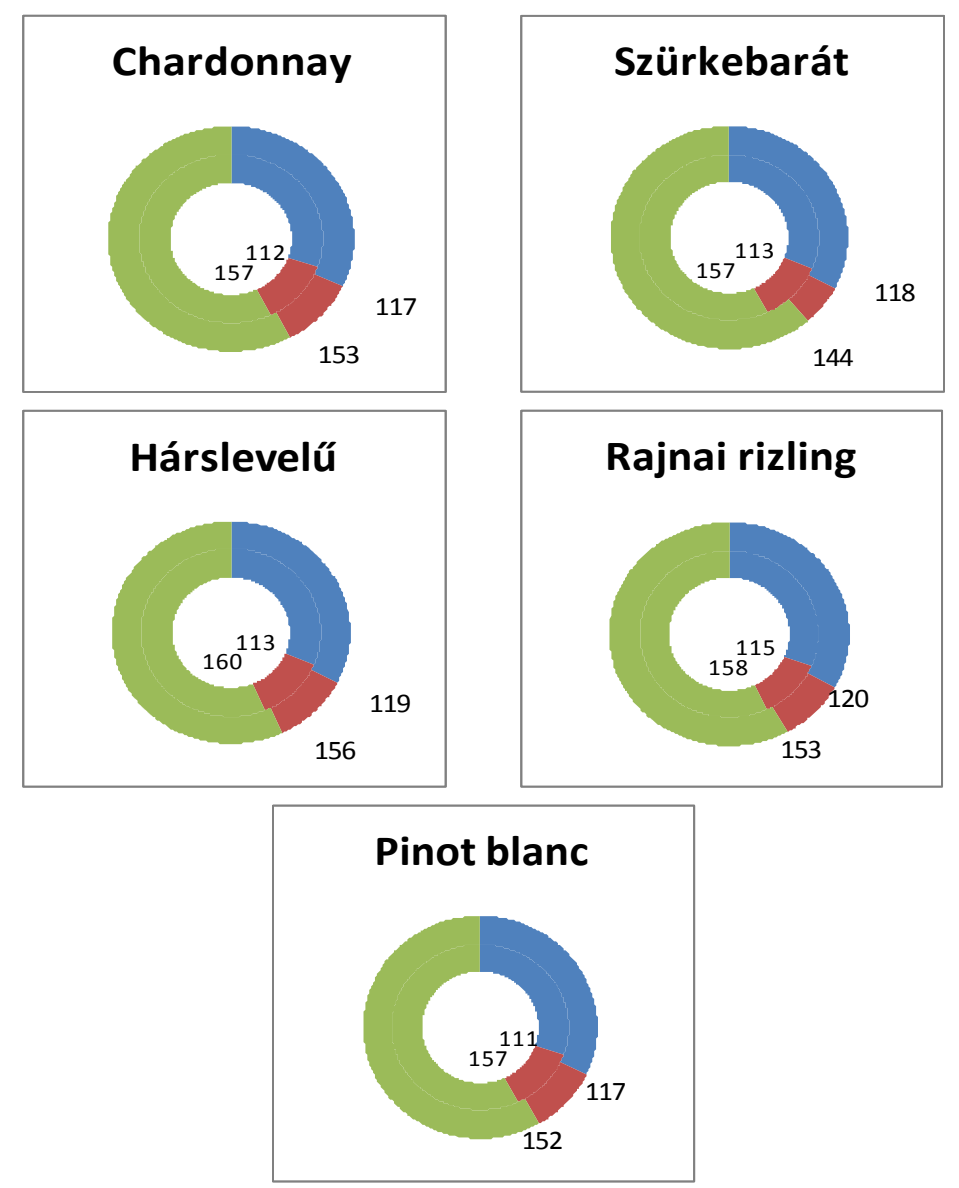

44. ábra A fenológiai modell eredményei a 2000-2004-es megfigyelt időszakra (külső kör), illetve a RegCM3.1 regionális klímamodell 2021-2050-es becsült meteorológiai adataira alapozva (belső kör). A számok a rügyfakadás és a virágzás kezdetét jelentik (Julianus nap).

A másik kései érésű Hárslevelü K.9 és P.41 klónok egyedül képviselik a pontuszi változatcsoportot, hiszen az előzőekben ismertetett fajták és klónok egytől egyig a nyugati fajtakörhöz tartoznak. A 2003-as év kivételével a modell ezekre a klónokra is jó becslést ad, 2003-ban azonban a tévedés magas, a modell maximális hibáját is eléri.

Mind az öt diagramot áttekintve, közös bennük az, hogy minden fajta esetében a 2002-es év volt az, amelyben a legnagyobb höösszeg kellet a tömeges virágzáshoz, s értékei magasan kiemelkednek a többi év értékeihez képest.

Regionális klímamodellek (RegCM) adatsorára (Giorgi et al. 1993) is alkalmaztuk a modellt, hogy választ kapjunk arra, hogy mire számíthatunk a jövőben különböző szcenáriók esetében. Miután a modell paramétereit meghatároztuk, a RegCM3.1 regionális (nagy felbontású, azaz sürü, 10 km-es rácspontozású) klímamodell becsléseire (Bartholy, et. al. 2009, Torma et. al. 2008) támaszkodva vizsgáltuk, mit prognosztizál a modell a 2021-2050-es időszakra (44. ábra).

Helvécián a modell a rügyfakadás kezdetét (piros) átlagosan öt nappal elöbbre, a fövirágzás kezdetét (zöld) öt nappal későbbre becsüli a vizsgált időszakban megfigyeltekhez képest (Ladányi és Hlaszny, 2010). 


\subsection{Hideghatást is figyelembe vevő fenológiai modell}

A mélynyugalmi höösszegeket is figyelembe vevő modellt a kecskeméti rügyfakadás adatsorokra futtattuk.

24. táblázat: Az Egyszerű Hőösszeg Modell (EHM) és a Hideghatás Modell (HHM) optimalizált paraméterei az összes vizsgált fajtára

\begin{tabular}{|c|c|c|c|c|c|c|}
\hline \multirow[b]{2}{*}{ Fajta } & \multirow{2}{*}{\multicolumn{2}{|c|}{ Egyszerü Höösszeg Modell }} & \multicolumn{4}{|c|}{ Hideghatás Modell } \\
\hline & & & \multicolumn{2}{|c|}{$\begin{array}{l}\text { Mélynyugalmi } \\
\text { hőakkumuláció }\end{array}$} & \multicolumn{2}{|c|}{$\begin{array}{c}\text { Kényszernyugalmi } \\
\text { hőakkumuláció }\end{array}$} \\
\hline \multirow{4}{*}{ Kékfrankos } & induló Julianus nap & 47 & $\mathrm{a}$ & 1,00 & \multirow[b]{2}{*}{$\mathrm{c}$} & \multirow{2}{*}{$-0,20$} \\
\hline & $T_{\text {alsó bázis }}\left({ }^{\circ} \mathrm{C}\right)$ & 4,54 & $\mathrm{~b}$ & 2,65 & & \\
\hline & $T_{\text {felsö bázis }}\left({ }^{\circ} \mathrm{C}\right)$ & 18,4 & $\begin{array}{c}T_{\text {bázis, HiH }} \\
\left({ }^{\circ} \mathrm{C}\right)\end{array}$ & 4,58 & $\mathrm{~T}_{\text {bázis, HöH }}\left({ }^{\circ} \mathrm{C}\right)$ & 12,11 \\
\hline & $G D D_{u_{-} k r i t} \quad\left({ }^{\circ} \mathrm{C}\right)$ & 260 & $\mathrm{CH}_{\text {krit }}$ & 14 & $G D D_{u \_k r i t}$ & 25 \\
\hline \multirow{4}{*}{ Hárslevelü } & induló Julianus nap & 41 & $\mathrm{a}$ & 1,00 & \multirow[b]{2}{*}{$\mathrm{c}$} & \multirow{2}{*}{$-0,26$} \\
\hline & $T_{\text {alsó bázis }}\left({ }^{\circ} \mathrm{C}\right)$ & 4,54 & $\mathrm{~b}$ & 2,65 & & \\
\hline & $T_{\text {felsö bázis }}\left({ }^{\circ} \mathrm{C}\right)$ & 19,17 & $\begin{array}{c}T_{\text {bázis }, H i H} \\
\left({ }^{\circ} \mathrm{C}\right)\end{array}$ & 4,48 & $\mathrm{~T}_{\text {bázis, HöH }}\left({ }^{\circ} \mathrm{C}\right)$ & 12,50 \\
\hline & $G D D_{u \_k r i t} \quad\left({ }^{\circ} \mathrm{C}\right)$ & 299 & $C H_{k r i t}$ & 8,82 & $G D D_{u \_k r i t}$ & 24,66 \\
\hline \multirow{4}{*}{ Szürkebarát } & induló Julianus nap & 47 & $\mathrm{a}$ & 0,92 & \multirow{2}{*}{$\mathrm{c}$} & \multirow{2}{*}{$-0,20$} \\
\hline & $T_{\text {alsó bázis }}\left({ }^{\circ} \mathrm{C}\right)$ & 4,54 & $\mathrm{~b}$ & 2,65 & & \\
\hline & $T_{\text {felsö bázis }}\left({ }^{\circ} \mathrm{C}\right)$ & 18,4 & $\begin{array}{c}T_{\text {bázisis,HiH }} \\
\left({ }^{\circ} \mathrm{C}\right)\end{array}$ & 4,48 & $\mathrm{~T}_{\text {bázis, HőH }}\left({ }^{\circ} \mathrm{C}\right)$ & 12,15 \\
\hline & $G D D_{u \_k r i t} \quad\left({ }^{\circ} \mathrm{C}\right)$ & 260 & $\mathrm{CH}_{\text {krit }}$ & 14,5 & $G D D_{u \_k r i t}$ & 25,25 \\
\hline \multirow{4}{*}{$\begin{array}{l}\text { Rajnai } \\
\text { rizling }\end{array}$} & induló Julianus nap & 41 & $\mathrm{a}$ & 1,00 & \multirow{2}{*}{$\mathrm{c}$} & \multirow{2}{*}{$-0,26$} \\
\hline & $T_{\text {alsó bázis }}\left({ }^{\circ} \mathrm{C}\right)$ & 4,54 & $\mathrm{~b}$ & 2,65 & & \\
\hline & $T_{\text {felsö bázis }}\left({ }^{\circ} \mathrm{C}\right)$ & 18,3 & $\begin{array}{c}T_{\text {bázis, HiH }} \\
\left({ }^{\circ} \mathrm{C}\right)\end{array}$ & 4,10 & $\mathrm{~T}_{\text {bázis, HöH }}\left({ }^{\circ} \mathrm{C}\right)$ & 12,50 \\
\hline & $G D D_{u_{-} k r i t} \quad\left({ }^{\circ} \mathrm{C}\right)$ & 291 & $\mathrm{CH}_{\text {krit }}$ & 8,81 & $G D D_{u \_k r i t}$ & 24,67 \\
\hline \multirow{4}{*}{ Generosa } & induló Julianus nap & 41 & $\mathrm{a}$ & 0,85 & \multirow[b]{2}{*}{$\mathrm{c}$} & \multirow{2}{*}{$-0,20$} \\
\hline & $T_{\text {alsó bázis }}\left({ }^{\circ} \mathrm{C}\right)$ & 4,40 & $\mathrm{~b}$ & 2,65 & & \\
\hline & $T_{\text {felső bázis }}\left({ }^{\circ} \mathrm{C}\right)$ & 19,18 & $\begin{array}{c}T_{\text {bázis, HiH }} \\
\left({ }^{\circ} \mathrm{C}\right) \\
\end{array}$ & 4,00 & $\mathrm{~T}_{\text {bázis, HöH }}\left({ }^{\circ} \mathrm{C}\right)$ & 12,39 \\
\hline & $G D D_{u \_k r i t} \quad\left({ }^{\circ} \mathrm{C}\right)$ & 306,51 & $\mathrm{CH}_{\text {krit }}$ & 8,82 & $G D D_{u \_k r i t}$ & 24,67 \\
\hline
\end{tabular}

$\mathrm{Az}$ eredmények értékeléséhez, a modellek összehasonlításához egytényezős varianciaanalízist és $t$-próbákat alkalmaztunk. A kalibráláshoz és a validáláshoz a helvéciai adatsor hosszúsága nem volt elegendő, ezért ebben a vizsgálatban már nem szerepel. Természetesen a kecskeméti adatsorra az egyszerü höösszeg modellt is lefuttattuk, így a két modell összehasonlítását statisztikai vizsgálatokkal is alátámasztottuk.

Az egyszerü hőösszegmodell (EHM) és a hideghatást is figyelembe vevő modell (Hideghatás modell - HHM) optimalizált paramétereit minden fajtára a 24. táblázatban találjuk. A hibatagok normalitása Kolmogorov-Smirnov, illetve a Shapiro-Wilk-féle teszt alapján $p>0,05$ szinten minden esetben elfogadható. 
Úgy ítéltük meg, hogy a HHM modell jobb eszköz a rügyfakadás becsléséhez, mivel a hiba, az átlagos és a maximális abszolút hiba értéke a legtöbb esetben jelentősen kisebb ennek a modellnek az esetében. A magyarázott szórásnégyzetek vagy varianciák $\left(\mathrm{R}^{2}\right)$ szignifikánsak mindkét modellre ( $<<0,05)$, a HHM modellé többnyire magasabb (25. , 26. táblázat).

25. táblázat: A hiba és az átlagos abszolút hiba kalibrált és validált értékei az öt fajta esetében

\begin{tabular}{|l|c|c|c|c|c|c|c|c|}
\hline & \multicolumn{4}{|c|}{ Hiba (RMSE, [nap]) } & \multicolumn{3}{c|}{ Átlagos abszolút hiba [nap] } \\
\hline & \multicolumn{2}{|c|}{ kalibrált } & \multicolumn{2}{c|}{ validált } & \multicolumn{2}{c|}{ kalibrált } & \multicolumn{2}{c|}{ validált } \\
\hline & EHM & HHM & EHM & HHM & EHM & HHM & EHM & HHM \\
\hline Kékfrankos & 3,74 & 2,40 & 5,53 & 4,96 & 2,89 & 2,00 & 3,89 & 3,83 \\
\hline Hárslevelü & 3,13 & 4,56 & 5,65 & 5,56 & 2,67 & 4,00 & 3,83 & 4,00 \\
\hline Szürkebarát & 3,92 & 3,91 & 4,97 & 4,81 & 3,00 & 3,30 & 3,70 & 4,10 \\
\hline Rajnai rizling & 4,43 & 3,82 & 3,87 & 3,97 & 2,60 & 3,20 & 2,32 & 3,26 \\
\hline Generosa & 3,23 & 4,50 & 5,53 & 5,18 & 2,44 & 3,78 & 4,32 & 4,47 \\
\hline
\end{tabular}

26. táblázat: A maximális abszolút hiba és a szórásnégyzet kalibrált és validált értékei az öt fajta esetében

\begin{tabular}{|c|c|c|c|c|c|c|c|c|}
\hline & \multicolumn{4}{|c|}{ Maximális abszolút hiba [nap] } & \multicolumn{4}{|c|}{$\mathrm{R}^{2}$} \\
\hline & \multicolumn{2}{|c|}{ kalibrált } & \multicolumn{2}{|c|}{ validált } & \multicolumn{2}{|c|}{ kalibrált } & \multicolumn{2}{|c|}{ validált } \\
\hline & EHM & HHM & EHM & HHM & EHM & HHM & EHM & HHM \\
\hline Kékfrankos & 8 & 4 & 13 & 10 & $0,86 * * *$ & $0,94 * * *$ & $0,64 * * *$ & $0,74 * * *$ \\
\hline Hárslevelü & 7 & 8 & 12 & 9 & $0,89 * * *$ & $0,75^{*}$ & $0,53 *$ & $0,61 * *$ \\
\hline Szürkebarát & 8 & 7 & 15 & 9 & $0,85 * *$ & $0,88 * * *$ & $0,71 * * *$ & $0,69 * * *$ \\
\hline Rajnai rizling & 10 & 7 & 10 & 7 & $0,68 *$ & $0,87 * *$ & $0,78 * * *$ & $0,75 * * *$ \\
\hline Generosa & 6 & 7 & 11 & 8 & $0,92 * * *$ & $0,79 * *$ & $0,64 * *$ & $0,67 * *$ \\
\hline
\end{tabular}

A megfigyelt és a modellek által becsült rügyfakadási időpontokat, valamint a RegCM3.1 éghajlati modell becsült meteorológiai adataira (1961-1990, 2021-2050, 2071-2100) futtatott rügyfakadási előrejelzéseket egytényezős varianciaanalízissel, valamint páros t-próbákkal hasonlítottam össze.

A 27. és 28. táblázatban található az időszeletek összehasonlítása, fajtánként, mindkét modellre külön futtatva. A szórások azonossága Levene-teszttel igazolható $(\mathrm{p}>0,05)$.

Az egyszerü hőösszegmodell az idő előrehaladtával az öt fajta esetében átlagosan 10-11 nappal korábbra teszi a rügyfakadás kezdetét a század végére. 
27. táblázat: A rügyfakadási időpontok átlagai és az ANOVA-összehasonlítások eredményei az öt fajta esetében az egyszerü höösszeg modellnél (A különböző betük a Tukey-, illetve a Scheffe-féle post hoc teszt alapján a szignifikáns különbségeket jelölik.)

\begin{tabular}{|c|c|c|c|c|c|}
\hline Fajta & $\mathrm{F}$ & Időszelet & Átlag [Julianus nap] & Tukey & Scheffe \\
\hline \multirow{4}{*}{ Kékfrankos } & \multirow{4}{*}{$19,817^{* * *}$} & $1977-2003$ & 116,70 & $\mathrm{~b}$ & $\mathrm{bc}$ \\
\hline & & 1961-1990 & 123,10 & c & c \\
\hline & & $2021-2050$ & 111,00 & $\mathrm{ab}$ & $\mathrm{ab}$ \\
\hline & & $2071-2100$ & 105,53 & $\mathrm{a}$ & $\mathrm{a}$ \\
\hline \multirow{4}{*}{ Szürkebarát } & \multirow{4}{*}{$19,432^{* * *}$} & $1977-2003$ & 116,3 & $\mathrm{~b}$ & $\mathrm{bc}$ \\
\hline & & $1961-1990$ & 123,1 & $\mathrm{c}$ & $\mathrm{c}$ \\
\hline & & $2021-2050$ & 111,0 & $\mathrm{ab}$ & $a b$ \\
\hline & & $2071-2100$ & 105,5 & $\mathrm{a}$ & $\mathrm{a}$ \\
\hline \multirow{4}{*}{ Hárslevelü } & \multirow{4}{*}{$20,715^{* * *}$} & $1977-2003$ & 119,15 & $\mathrm{~b}$ & $\mathrm{~b}$ \\
\hline & & 1961-1990 & 126,90 & $\mathrm{c}$ & c \\
\hline & & $2021-2050$ & 114,33 & $a b$ & $a b$ \\
\hline & & $2071-2100$ & 108,53 & $\mathrm{a}$ & $\mathrm{a}$ \\
\hline \multirow{4}{*}{ Rajnai rizling } & \multirow{4}{*}{$20,132^{* * *}$} & $1977-2003$ & 118,44 & $\mathrm{~b}$ & $\mathrm{~b}$ \\
\hline & & 1961-1990 & 126,13 & $\mathrm{c}$ & $\mathrm{c}$ \\
\hline & & $2021-2050$ & 113,77 & $a b$ & $a b$ \\
\hline & & $2071-2100$ & 107,97 & $\mathrm{a}$ & $\mathrm{a}$ \\
\hline \multirow{4}{*}{ Generosa } & \multirow{4}{*}{$20,571^{\text {**** }}$} & $1977-2003$ & 119,26 & $\mathrm{~b}$ & $\mathrm{~b}$ \\
\hline & & 1961-1990 & 126,90 & $\mathrm{c}$ & $\mathrm{c}$ \\
\hline & & $2021-2050$ & 114,50 & $\mathrm{ab}$ & $a b$ \\
\hline & & $2071-2100$ & 108,77 & $\mathrm{a}$ & $\mathrm{a}$ \\
\hline
\end{tabular}

A hideghatást is fegyelembe vevő modell a Kékfrankos esetében 14,5 nappal, a Szürkebarát esetében 13,5 nappal, a Hárslevelü esetében 15,5 nappal, a Rajnai rizlingnél 17 nappal és a Generosánál 13 nappal korábban jelzi átlagosan a rügyfakadást a század utolsó 30 évére. 
28. táblázat: A rügyfakadási időpontok átlagai és az ANOVA-összehasonlítások eredményei az öt fajta esetében a hideghatást is figyelembe vevő modellnél (A különböző betük a Tukey-, illetve a Scheffe-féle post hoc teszt alapján a szignifikáns különbségeket jelölik.)

\begin{tabular}{|c|c|c|c|c|c|}
\hline Fajta & $\mathrm{F}$ & Időszelet & Átlag [Julianus nap] & Tukey & Scheffe \\
\hline \multirow{4}{*}{ Kékfrankos } & \multirow{4}{*}{$11,508^{* * *}$} & $1977-2003$ & 117,41 & $\mathrm{~b}$ & $\mathrm{~b}$ \\
\hline & & 1961-1990 & 113,33 & $\mathrm{~b}$ & $\mathrm{~b}$ \\
\hline & & $2021-2050$ & 104,90 & $\mathrm{a}$ & $\mathrm{a}$ \\
\hline & & $2071-2100$ & 102,90 & $\mathrm{a}$ & $\mathrm{a}$ \\
\hline \multirow{4}{*}{ Szürkebarát } & \multirow{4}{*}{$10,243^{* * *}$} & $1977-2003$ & 116,33 & $\mathrm{~b}$ & $\mathrm{~b}$ \\
\hline & & $1961-1990$ & 113,33 & $\mathrm{~b}$ & $\mathrm{~b}$ \\
\hline & & $2021-2050$ & 104,90 & $\mathrm{a}$ & $\mathrm{a}$ \\
\hline & & $2071-2100$ & 102,90 & $\mathrm{a}$ & $\mathrm{a}$ \\
\hline \multirow{4}{*}{ Hárslevelü } & \multirow{4}{*}{$19,099^{* * * *}$} & $1977-2003$ & 119,07 & $\mathrm{~b}$ & $\mathrm{~b}$ \\
\hline & & $1961-1990$ & 121,60 & $\mathrm{~b}$ & $\mathrm{~b}$ \\
\hline & & $2021-2050$ & 109,83 & $\mathrm{a}$ & $\mathrm{a}$ \\
\hline & & $2071-2100$ & 103,47 & $\mathrm{a}$ & a \\
\hline \multirow{4}{*}{ Rajnai rizling } & \multirow{4}{*}{$18,331^{* * *}$} & $1977-2003$ & 119,26 & $\mathrm{~b}$ & $\mathrm{~b}$ \\
\hline & & $1961-1990$ & 122,53 & $\mathrm{~b}$ & $\mathrm{~b}$ \\
\hline & & $2021-2050$ & 110,33 & $\mathrm{a}$ & $\mathrm{a}$ \\
\hline & & $2071-2100$ & 105,37 & $\mathrm{a}$ & $\mathrm{a}$ \\
\hline \multirow{4}{*}{ Generosa } & \multirow{4}{*}{$16,026^{* * * *}$} & $1977-2003$ & 117,89 & $\mathrm{~b}$ & $\mathrm{~b}$ \\
\hline & & 1961-1990 & 121,10 & $\mathrm{~b}$ & $\mathrm{~b}$ \\
\hline & & $2021-2050$ & 108,83 & $\mathrm{a}$ & $\mathrm{a}$ \\
\hline & & $2071-2100$ & 104,62 & $\mathrm{a}$ & $\mathrm{a}$ \\
\hline
\end{tabular}

$* * * \mathrm{p}<0,001 * * \mathrm{p}<0,01 * \mathrm{p}<0,05+\mathrm{p}<0,1$ szinten szignifikáns

Páros $t$-próbával összehasonlítottam a megfigyelt rügyfakadási adatokat a két modell által becsült rügyfakadási időpontokkal. A HHM modell a Rajnai rizling kivételével pontosabb (magasabb szignifikancia szinten igazolhatóan közelítő) becslést adott a rügyfakadás időpontjára a megfigyelt értékhez viszonyítva (29. táblázat). 
29. táblázat: A megfigyelt és a modellek által becsült rügyfakadási időpontok átlagai fajtánként [ Julianus nap]

\begin{tabular}{|c|c|c|c|c|c|}
\hline \multicolumn{1}{|c|}{ Fajta } & Megfigyelt & 1. modell & $\mathrm{p}$ & 2. modell & $\mathrm{p}$ \\
\hline Kékfrankos & 117,05 & 116,70 & 0,45 & 117,41 & 0,83 \\
\hline Szürkebarát & 117,53 & 116,37 & 0,15 & 116,33 & 0,29 \\
\hline Hárslevelű & 117,90 & 119,15 & 0,92 & 119,07 & 0,97 \\
\hline Rajnai rizling & 116,89 & 118,44 & 0,78 & 119,26 & 0,40 \\
\hline Generosa & 116,50 & 119,26 & 0,60 & 117,89 & 0,97 \\
\hline
\end{tabular}

Páros $t$-próbával hasonlítottam össze a két modell által előrejelzett átlagos rügyfakadási időpontokat is. Ennek eredményeit a 30. táblázatban foglaltam össze.

30. táblázat: A két modell által becsült átlagos rügyfakadási időpontok fajtánként [Julianus nap]

\begin{tabular}{|c|c|c|c|c|}
\hline Időszelet & Fajta & 1. modell & 2. modell & $\mathrm{p}$ \\
\hline \multirow{5}{*}{$7703,6190,2150,7100$} & Kékfrankos & 114,24 & 109,64 & $p<0,001$ \\
\hline & Szürkebarát & 114,15 & 109,37 & $\mathrm{p}<0,001$ \\
\hline & Hárslevelű & 117,23 & 113,49 & $p<0,001$ \\
\hline & Rajnai rizling & 116,58 & 114,37 & $\mathrm{p}<0,001$ \\
\hline & Generosa & 117,52 & 113,11 & $p<0,001$ \\
\hline \multirow{5}{*}{$1977-2003$} & Kékfrankos & 116,70 & 117,41 & $\mathrm{p}=0,48$ \\
\hline & Szürkebarát & 116,37 & 116,33 & $\mathrm{p}=0,97$ \\
\hline & Hárslevelü & 119,15 & 119,07 & $\mathrm{p}=0,90$ \\
\hline & Rajnai rizling & 118,44 & 119,26 & $\mathrm{p}=0,16$ \\
\hline & Generosa & 119,26 & 117,89 & $\mathrm{p}<0,05$ \\
\hline \multirow{5}{*}{ 1961-1990 } & Kékfrankos & 123,10 & 113,33 & $\mathrm{p}<0,001$ \\
\hline & Szürkebarát & 123,10 & 113,33 & $p<0,001$ \\
\hline & Hárslevelü & 126,90 & 121,60 & $\mathrm{p}<0,001$ \\
\hline & Rajnai rizling & 126,13 & 122,53 & $p<0,01$ \\
\hline & Generosa & 126,90 & 121,10 & $\mathrm{p}<0,001$ \\
\hline \multirow{5}{*}{$2021-2050$} & Kékfrankos & 111,00 & 104,90 & $\mathrm{p}<0,01$ \\
\hline & Szürkebarát & 111,00 & 104,90 & $\mathrm{p}<0,01$ \\
\hline & Hárslevelű & 114,33 & 109,83 & $p<0,001$ \\
\hline & Rajnai rizling & 113,77 & 110,33 & $p<0,01$ \\
\hline & Generosa & 114,50 & 108,83 & $\mathrm{p}<0,001$ \\
\hline \multirow{5}{*}{$2071-2100$} & Kékfrankos & 106,14 & 102,90 & $\mathrm{p}=0,077$ \\
\hline & Szürkebarát & 106,14 & 102,90 & $\mathrm{p}=0,077$ \\
\hline & Hárslevelű & 108,53 & 103,47 & $p<0,01$ \\
\hline & Rajnai rizling & 107,97 & 105,37 & $\mathrm{p}=0,086$ \\
\hline & Generosa & 109,41 & 104,62 & $\mathrm{p}<0,01$ \\
\hline
\end{tabular}

Ha a négy idősor (1977-2003, 1961-1990, 2021-2050, 2071-2100) átlagos rügyfakadási becsléseit egymáshoz hasonlítjuk, akkor azt mondhatjuk, hogy a két modell eredményei egymástól szignifikánsan eltérnek. Amikor a megfigyelt időszak (1977-2003) rügyfakadási eredményeit hasonlítottam össze, azt az eredményt kaptam, hogy a két modell eredményei között nincs szignifikáns különbség. A referencia-időszakban (1961-1990) és a 2021-2050 közötti időszakban a két fenológiai modell által becsült rügyfakadási időpontok között is szignifikáns eltérés van. A 2071-2100-as időszakra a két modell becslése már közelít egymáshoz, mert az eltérések nem, vagy enyhén szignifikánsak. 
A négy idősor becsléseit és előrejelzéseit felhasználva a rügyfakadási időpontok gyakorisági hisztogramjait is létrehoztam (45. ábra).
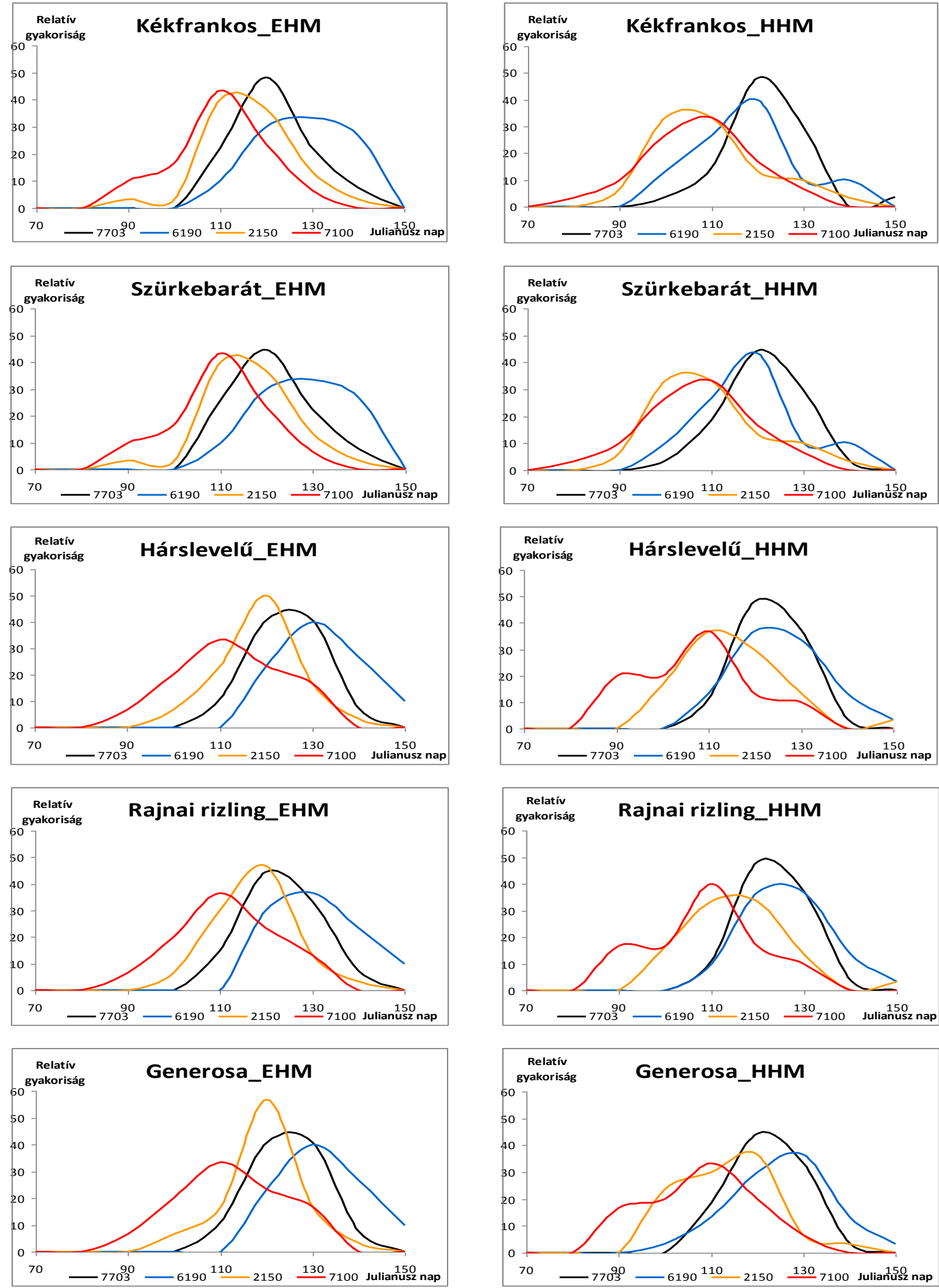

45. ábra: A rügyfakadási időpontok relatív gyakorisági hisztogramjai az 1977-2003-ig terjedő megfigyelt adatok esetén és a RegCM3.1 klímamodell 1961-1990-es referencia-időszakára, valamint a 2021-2050-es és 2071-2100-as időszeletekre 
A 2071-2100 között a rügyfakadás időpontok szórása megnő, az évek között sokkal nagyobb ingadozás várható. Nő a valószínüsége a nagyon korai és a nagyon kései rügyfakadásnak is. A korai rügyfakadás oka a rövid, de megfelelő hideghatású tél, míg a kései rügyfakadás a nagyon enyhe tél eredménye, amikor a szőlő számára csak nagyon lassan gyülik össze a mélynyugalom megtöréséhez szükséges hidegösszeg.

Megállapítom, hogy a mélynyugalmi időszakot is figyelembe vevő modell (HHM) esetében az öt fajtára vonatkozó rügyfakadási időpontok a megfigyelt időszakban (1977-2003) és a referencia-időszakban (1961-1990) is átlagosan a 118. Julianus napra esnek, ami azt jelenti, hogy az eltérés a két időszak között nem szignifikáns. A 2021-2050-es és a 2071-2100-as időszakok átlagértékei (108. és 104. Julianus nap) egymástól szignifikánsan nem térnek el, de a megfigyelt és a referencia-időszaktól már szignifikánsan különböznek $(\mathrm{p}<0,001)$.

A rügyfakadási időpontok korábbra tolódása mellett a rügyfakadás idejének terjedelme is várhatóan szélesedik az időben. Ez azt jelenti, hogy a várható extremális időjárási események következményeként akár extrém korai és extrém kései időpontok előfordulására is számíthatunk. 


\section{6. Új és újszerü tudományos eredmények}

1. 1977 és 2003 közötti időszakban Kecskeméten mért napi hőmérsékleti és csapadékadatokból képzett 36 klímaindikátort vizsgálva megmutattam, hogy a kecskeméti körzetben a 27 év alatt szignifikáns növekedés következett be a Huglin- és Winkler-index értékekben, a júliusi középhőmérsékletben, a tenyészidő átlagos és maximum hőmérsékletében, az érésidő középhőmérsékletében, a szüretidő maximum hőmérsékletében, a meleg és nyári napok számában, valamint a Gladstones-féle tavaszi fagyindex esetében is. Az indikátoroknak a RegCM3.1 regionális klímamodell becslései alapján várható értékeit az 1961-1990-es referencia-időszakra, valamint a 2021-2050 és a 2071-2100-as jövőbeli időszeletre vonatkozóan vizsgálva megállapítottam, hogy az éghajlati modell becslései 2021-től az egyes hőmérsékleti indikátorok átlagértékeinek további emelkedését vetítik elő. A csapadék éves mennyisége várhatóan nem fog emelkedni. 2050 után a nyári és a tenyészidőszakban hullott csapadékmennyiség csökkenésére, valamint az őszi és téli csapadékmennyiség növekedésére kell számítanunk Kecskemét körzetében.

2. A nemzetközi szakirodalomban általánosan használt tenyészidőszak-számítási módszereket összehasonlítva megmutattam, hogy a klímaváltozás egyre jobban érezhető hatásai mellett fokozottan indokolttá válik az interpolációs módszer alkalmazása, az egyre gyakoribbá váló extrém jelenségek ugyanis a hagyományos módszert egyre pontatlanabbá teszik.

3. A szőlő rügyfakadásának és virágzásának becslésére egy egyszerü hőösszeg modellel közelítettem 6 szőlőfajta és klónjaik ötévi megfigyeléseit Helvécián. A modellben eltértem a szakirodalomban használatos gyakorlattól, és a bázishőmérsékletet, valamint a hőösszeg akkumulációjának kezdeti időpontját is optimalizálással határoztam meg. A helvéciai szőlőültetvények rügyfakadásának becslését elvégezve optimalizálással $6{ }^{\circ} \mathrm{C}-$ os bázishőmérsékletet és február 10-ei optimális indulási napot határoztam meg a rügyfakadásra. A fővirágzás kezdetének becsléséhez alsó és felső bázishőmérsékletet is használtam, melyekre $11^{\circ} \mathrm{C}$, illetve $26^{\circ} \mathrm{C}$ érték adódott optimálisként.

4. Az egyszerü hőösszegmodellen kívül egy hideghatást is figyelembe vevő fenológiai modellt is készítettem a rügyfakadás becslésére öt Kecskemét-Katonatelepen telepített fajtára, 27 éves adatsor alapján. Erre az idősorra is meghatároztam az egyszerű hőösszegmodell optimális paramétereit. A két modell becsléseit összehasonlítva megmutattam, hogy a hideghatást is figyelembe vevő modellel pontosabb eredményt kaptunk mindegyik vizsgált kecskeméti fajta esetében. 
5. Az adatok mennyisége a kecskeméti adatsorra a kalibráláson kívül a validálást is lehetővé tette, így mód nyílt arra, hogy a modelleket a RegCM3.1 regionális klímamodell 19611990-es referencia-időszakra, valamint a 2021-2050-re és a 2071-2100-as jövőbeli időszeletekre vonatkozó becsléseivel is futtassam. Az eredmények alapján elmondhatjuk, hogy 2020 után várhatóan minden fajta rügyfakadása korábbra tolódik a kecskeméti körzetben, de 2070 után a rügyfakadás idejének várható tartománya is kiszélesedik. Az egyszerü hőösszegmodell az idő előrehaladtával az öt fajta esetében átlagosan 10-11 nappal korábbra teszi a rügyfakadás kezdetét a század végére. A hideghatást is fegyelembe vevő modell a Kékfrankos esetében 14,5 nappal, a Szürkebrát esetében 13,5 nappal, a Hárslevelü esetében 15,5 nappal, a Rajnai rizlingnél 17 nappal és a Generosánál 13 nappal korábban jelzi átlagosan a rügyfakadást a század utolsó 30 évére. 


\section{KÖVETKEZTETÉSEK}

Az 1977-2004-ig terjedő időszak kecskeméti hőmérsékleti és csapadékadatok alapján 36 klímaindikátor átlagértékét meghatároztam, és megbecsültem a jövőbeli változásukat a RegCM3.1 regionális éghajlati modell segítségével. Kiszámítottam mindkét helyszínen a vizsgált évek tenyészidejének hosszait kétféle módszerrel, majd ezeket statisztikailag is összehasonlítottam A helvéciai és kecskeméti kísérleti ültevények fehér- és vörösborszőlöfajtáinak 1977 és 2004 között felvételezett rügyfakadási adatai alapján becsléseket végeztem a csak a kényszernyugalmi időszakot használó és a mélynyugalmi hatást is figyelembe vevő hőösszegzési modellekkel. A RegCM3.1 klímamodell segítségével megbecsültem a jövőbeli várható rügyfakadási időpontokat.

1. Az Európai Unió „Alkalmazkodás a klímaváltozáshoz” címü Zöld Könyve szerint Európa egyik legsérülékenyebb területéhez tartozik a Kárpát-medence, ahol a jelentős hőmérséklet-emelkedés és a csökkenő csapadékmennyiség együttes hatása olyan területeken jelentkezik, melyeken már most is vízhiánnyal küzdenek. A 2007-es ENSZ-jelentés szerint Magyarország a klímaváltozás természeti sokszínűségre gyakorolt hatása szempontjából a világ egyik legsérülékenyebb állama (SEG, 2007). Harnos és munkatársai (2008) szerint a hazai átlaghőmérséklet emelkedése másfélszer gyorsabb, mint a globális felmelegedés üteme. Részletes klímaindikátor-vizsgálatunk során mi a fentieket megerősítő és Bartholy et al., (2004) megállapításaival egybehangzó eredményeket kaptuk:

- A hömérsékleti indikátorok közül az 1977-2003 közötti hőmérsékleti adatok alapján, az Huglin- és Winkler-index, a júliusi középhőméréséklet, a tenyészidő átlagos és maximum hőmérséklete, az érésidő középhőmérséklete, a szüretidő maximum hőmérséklete a 26 év alatt szignifikánsan növekedtek. Nincs szignifikáns változás a januári középhőmérsékletben, a tenyészidő minimum hőméréskletében, a téli minimum hőmérsékletben, a hideg éjszaka indexben és a kontinentalitás indexben. Mindez azt jelenti, hogy bár a tenyészidőszak hőméréskleti értékei növekedtek, a téli időszak nem lett enyhébb.

- Az extremális indexek közül jelentősen megnőtt a meleg és a nyári napok száma, valamint a Gladstones-féle tavaszi fagyindex értéke. Kisebb mértékben növekedett az extrém meleg napok száma, a fagyos napok száma, a tavaszi fagyos napok száma, a Wolf-Boyer-féle tavaszi fagyindex értéke, a hőmérséklet napi terjedelme, az áprilisi középhőmérséklet napi terjedelme, a napi hőmérséklet ingadozás összege és az RGP index. Mindez arra enged következtetni, hogy a tavaszi, rügyfakadás utáni fagykárosodás 
kockázata növekedett. A 26 év alatt nem változott a jeges napok száma, az őszi fagyos napok száma és a szüreti középhőmérséklet napi ingadozása.

- A csapadékindexek évenkénti átlagértékeiben nem volt szignifikáns változás 1977 és 2003 között, vagyis a kecskeméti körzetben nem esett több vagy kevesebb csapadék az átlagosnál.

- Az 1961-1990 közötti referencia-időszakra a RegCM3 modell becslései a legtöbb klímamodell esetében kisebb értékeket adott, mint az 1977 és 2003 közötti időszakra. Alacsonyabb értékekkel rendelkezik tehát a Huglin- és Winkler-index, a júliusi középhöméréséklet, a tenyészidő átlagos és maximum hőmérséklete, az érésidő középhőmérséklete, a szüretidő maximum hőmérséklete, az extrém meleg napok száma, stb. Enyhébbek a téli, illetve a minimumhőmérsékleteket mérő indexek értékei. Mindez azt jelenti, hogy az 1977-2003 közötti időszakban a fokozódó melegedés nagyobb hideggel járt együtt, vagyis a minimum és maximum hőméréskletek ingadozása éves átlagban nagyobb, mint a referencia-időszakban.

- Az 1961-1990-es időszakban átlagosan több csapadék is hullott, mint 1977 és 2003 között. Eloszlása a tenyészidőszakok során kedvezőbb volt.

- A RegCM3 klímamodell 2021-2050-re előrejelzett Huglin- és Winkler-index értékek, a júliusi középhőméréséklet, a tenyészidő átlagos és maximum hőmérséklete, az érésidő középhőmérséklete, a szüretidő maximum hőmérséklete a megfigyelt időszakhoz képest, kevesebb, de a referencia-időszak értékeinél már több. A januári középhőmérséklet, a tenyészidőszak minimum hőmérséklete, a téli minimumhőmérséklet és a hideg éjaszaka index az 1977-2003-as és az 1961-1990-es időszakhoz képest is enyhébb átlagértékeket mutat.

- A 2021-2050-es időszakban az extremális indexek átlagértékei előreláthatólag még alacsonyabbak lesznek, mint a megfigyelt időszakban, de az extrém meleg napok száma már jelentősen növekedhet. Csökken a fagyos, a jeges, a tavaszi fagyos és az őszi fagyos napok száma, ami akár kedvező lehet a szőlő rügyfakadása és érése szempontjából. Az áprilisi és a szüreti középhőmérséklet napi terjedelme, a napi hőmérsékleti kilengés terjedelme, valamint a Riberau-Gayon-Peynaud Index átlagértékei a megfigyelt időszakhoz képest még mindig alacsonyabbak.

- A 2021-2050-es időszakra előrejelzett csapadékindexek közül az előrejelzések szerint az éves és a téli csapadékmennyiségben, valamint a tenyészidőszak csapadékmennyiségében szignifikáns növekedés várható. Ez azonban nem annyira jó hír, hiszen a téli csapadékmennyiség növekedése a terméseredmények szempontjából jelentéktelen. Az érésidő csapadékmennyisége kisebb mértékben, de várhatóan növekedni fog, ami 
kedvező helyzetet teremt a szőlő botritiszes megbetegedésének, csökkentve a termésmennyiséget és növelve a költségeket.

- A 2071-2100-as évek, jóllehet még távol vannak, éghajlati modellünk előrejelzései viszont nagyságrendekkel erőteljesebb átlagértékeket, nagyobb szélsőértékeket jósolnak, mint a megfigyelt, a referencia, vagy akár a 2021-től 2050-ig terjedő időszakra. A hőmérsékleti indikátorok átlagértékei egy kivételével szignifikáns növekedést mutatnak. Egyedül a kontinentális hatás indexértékére adott a modell alacsonyabb elörejelzést, mint a megfigyelési időszakra, de az 1961-1990-es és az 1977-2003-as időszakhoz képest ebben is növekedés várható.

- A 2071-2100-as időszakra a szélsőséges hőmérsékleti indikátorok közül az extrém meleg, a meleg és a nyári napok száma várhatóan ugrásszerüen megnő az 1977-2003 között mért értékekhez képest. A fagyos és jeges napok száma szignifikánsan csökken. Kedvező lehet a szőlő számára, hogy a modell szerint ebben a 30 évben csökkenhet a tavaszi és az őszi fagyos napok száma. A Gladstones- és a Wolf-Boyer féle tavaszi fagyindex értékek, kis mértékben ugyan, de várhatóan csökkenni fognak. A júliusi hőmérséklet-ingadozás nagyobb lesz a megfigyelt időszakhoz képest. Az áprilisi és a szüreti középhőmérséklet nem változik szignifikánsan. A június és október között napi hőmérséklet-ingadozás mértéke a megfigyelt időszakhoz képest előreláthatólag alacsonyabb marad. Az evapotranspirációs indexértékek növekedése várható.

- A klímamodell a 2071-2100-as időszakra szignifikánsan több éves csapadékmennyiséget jósol. Sajnos a nyári csapadékmennyiség viszont szignifikánsan csökken, ami azt jelenti, hogy fel kell készülni az aszályos időjárás fokozódására. Megnövekszik a téli csapadékmennyiség, de a tenyészidőszak csapadékmennyiségének változása a négy vizsgált idősor alatt nem változott szignifikánsan. Nem lesz lényegesen kevesebb, de több sem. A virágzáskori csapadékmennyiség várhatóan csökken, de az érésidő csapadékmennyisége szignifikánsan növekedhet. A tenyészidőszakok csapadékos napjainak száma a vizsgált időszakhoz képest növekedhet, de a referencia-időszakhoz és a 2021-2050-es időszakhoz képest várhatóan csökkenni fog.

2. Csepregi (1997) a tenyészidőszak-számításra az ún. interpolációs módszert javasolja. Nemzetközileg is, széles körben elterjedt Kozma (1991) egyszerübb tenyészidőszak-számítási módszere is.

- E kétféle módszerrel elvégeztem a tenyészidőszak-számításokat, két helyszínen. A két módszert összehasonlítva megmutattam, hogy a klímaváltozás egyre jobban érezhető hatásai mellett fokozottan indokolttá válik az interpolációs módszer alkalmazása, az 
egyre gyakoribbá váló extrém jelenségek ugyanis a hagyományos módszert pontatlanabbá teszik.

3. 1989-ben Murray és munkatársai az emelkedő téli hőmérséklet hatását vizsgálták fás növények rügyfakadási idejére Skóciában. Vizsgálataihoz a Thermal Time modellt (Cannel és Smith, 1983) alkalmazták. A különböző skóciai fafajok rügyfakadását megvizsgálva azt az eredményt kapták, hogy a melegedő téli hőmérséklet hatására inkább késhet a rügyfakadás azoknál a viszonylag nagy hidegösszeg-igényü fajoknál, melyek viszonylag enyhe telü termőhelyen élnek. Ezzel szemben a rügyfakadás felgyorsult az alacsony hidegösszeg igényü fajoknál, melyek viszonylag hideg termőhelyen élnek.

Ezzel ellentétes eredményt kapott 1991-ben Hänninen, aki 73 év hőmérsékleti adatsorát felhasználva fás növények rügyfakadási idejét és az ezt követő fagykárkockázatot vizsgálta közép-finnországi feltételek között. Számításaihoz Sarvas (1974) Hänninen által javított (1990) rügyfakadási szimulációs modelljét használta kétszeres légköri $\mathrm{CO} 2$ szintü éghajlati szcenáriót (Bach, 1987) feltételezve. Az előrejelzés szerint a kétszeresére emelkedett széndioxid-szint hatására megemelkedő középhőmérséklet siettetni fogja a fák rügyfakadását, megnövelve ezzel a rügyfakadás után bekövetkező fagykárok kockázatát (Hänninen, 1991).

A két ellentétes eredmény megjelenése után Kramer (1994 a) tovább boncolgatta a témát, feltéve a kérdést, hogy mi okozhatta az ellentétes eredményeket: talán a különböző modellek vagy az eltérő klímaszcenáriók alkalmazása? Esetleg az eltérő, lokális termőhelyekhez adaptálódott különböző fajok? Vizsgálataihoz a Hollandiában és Németországban a fenológiai hálózat által gyüjtött 11 fafaj adatsorát használta. Az adatok elemzéséhez a Sequental (Sarvas, 1974; Hänninen; 1990; Kramer 1994 b) és Alternating (Murrey et al., 1989) modelleket használta, valamint egyenletesen (uniform temperature increase scenario) és változóan melegedő (non-uniform temperature increase scenario) klímaszcenárókat. Végeredményül mindkét modell emelkedő vagy konstans minimum hőmérsékletet jósolt a rügyfakadás ideje körül, mindkét szcenárió esetében, a Larix decidua, Betula pubescens, Tilia platyphylla, Fagus sylvatica, Tilia cordata, Quercus rubra, Quercus robur, Fraxinus excelsior, Quercus petraea, Picea abies és a Pinus sylvestris fajok németországi és holland termőhelyein. Ennek eredményeként pedig a tavaszi fagykárok csökkenése lehetséges. A tanulmány felfedte azt is, hogy a fajok különböznek a változó téli hőmérsékletre adott válaszukban. Azok a fajok, melyek rügyfakadása április végén következik be, erösebben reagálnak a hőmérsékletváltozásra, mint azok, amelyek május első hetében fakadnak. Ez várhatóan hatással van az egyes élőhelyeken élő fajok kompetitív kapcsolataira, mivel a már meglévő különbségeket fokozza egy ilyen eltérő válaszadás. Ugyanis egy 1996-os kutatásban azt sikerült bizonyítani, hogy a vegyeserdőkben élő 
fajok nettó elsődleges produkciója (NPP - net primary production) magasabb, mint a monokultúrában élő fajok esetében (Kramer et al., 1996).

Mi is célul tüztük ki, hogy olyan fenológiai modelleket fogalmazzunk meg, illetve fejlesszünk tovább, amelyek a szőlő rügyfakadásának, illetve virágzásának idejét megfelelő pontossággal becsülik azzal a céllal, hogy összehasonlító vizsgálatot végezzünk a rendelkezésre álló adatok alapján a különböző modellekre és fajtákra, és ez alapján javaslatot tehessünk egy, a vizsgálatba bevont modellek közül a legmegfelelöbbre. További összehasonlító vizsgálatot is végeztünk a fenológiai modellekre a RegCM3.1 regionális klímamodell által a 1961-1990-es referencia-időszakra, valamint a 2021-2050 és a 2071-2100-as jövöbeli időszeletre vonatkozó becslések alapján, a Kunsági borvidéken várható változások megfogalmazása céljából. A kapott eredményeink a fent idézett nemzetközi kutatások eredményeibe az alábbiak szerint illeszkednek:

- Egy előzetes rügyfakadásbecslés modellezéséhez 5 fehérborszőlő-fajta (Chardonnay, Rajnai rizling, Hárslevelü, Pinot blanc és Szürkebarát) és klónjaik (Chardonnay 75 és 96, Rajnai rizling 239, 378, 391, 49, Hárslevelü K.9, P.49, Szürkebarát 34, 52, Pinot blanc 54, 55 és D55) 2000 és 2004 között felvételezett rügyfakadási adatait használtam fel. A becslést az általánosan használt egyszerü hőösszegzési modell segítségével végeztem. Megállapítottam, hogy a szakirodalomban áltlánosan elterjedt $10^{\circ} \mathrm{C}$-os bázishőmérséklet helyett, már jóval alacsonyabb hőméréskleten elkezdi a szőlőtőke a hőösszegeket gyüjteni. A mi esetünkben ez $6{ }^{\circ} \mathrm{C}$-nál indult el. Az optimális indulási napot a 41 . Julianus napban (február 10.) határoztam meg. Mivel a klímaváltozás módosító hatásait figyelembe véve nem szerencsés ezt a napot rögzíteni, ezért ezt a paramétert időről időre optimalizálni szükséges az új megfigyelésekre támaszkodva.

- A fenti egyszerü modellel megbecsültem a vizsgált fajták, illetve klónjaik tömeges virágzásának idejét. A becsléshez Gladstones (1992) javaslatára egy felső bázishőmérsékletet is bevezettünk. Az optimális alsó bázis hőmérsékletet $11^{\circ} \mathrm{C}$-ra, a felső bázishőmérsékletet pedig $26^{\circ} \mathrm{C}$-ra kalibráltuk. A modell a RegCM3.1 regionális klímamodell adataival futtatva Helvécián a rügyfakadás kezdetét az évszázad közepére átlagosan öt nappal előbbre, a fövirágzás kezdetét öt nappal későbbre becsüli a vizsgált időszakban megfigyeltekhez képest. Ez némileg ellentmond Zanathy (2008) által közölt, közelmúltbeli megfigyeléseknek, ám hangsúlyozzuk, hogy a 21. század közepére vonatkozó prognózisok közvetlenül nincsenek ellentmondásban egy évtizedekkel korábban megfigyelt tendenciával. Eredményeink továbbá megfelelnek Dunne et al., (2003), Arft et al., (1999), Price és Waser, (1998) és Dunne et al., (2003) eredményeinek, akik a melegedéssel egyidőben számos esetben a növények növekedésének és a 
virágzásának gyorsulását dokumentálták, különösen a kora tavaszi virágzású fajok esetében. A tenyészidőszakban később fakadó növények esetében arról számoltak be, hogy azok vagy nem reagálnak szignifikánsan a melegedésre (Dunne et al., 2003), vagy késik a fenológiai fázisuk, különösen, ha a hőmérséklet fiziológiai türőképességük fölé emelkedik (Sherry et al., 2007).

- A rügyfakadás időpontjának becslését a kecskeméti hosszabb idősorra (27 év) is elvégeztem 5 fajtára, de már kétféle modellel. Az egyszerü hőösszegmodellnél a Rajnai rizling, a Generosa és a Hárslevelü fajták a 41. Julianus naptól kezdték gyüjteni a hőösszegeket, míg a Szürkebarát és a Kékfrankos a 47. Julianus naptól. Az alsó bázishőmérséklet $4-5^{\circ} \mathrm{C}$, a felső 18,3 és $19,2{ }^{\circ} \mathrm{C}$ között mozgott.

- Mivel a szőlő rügyfakadását a nyugalomban ért hideghatást követően, de attól erősen függően elsősorban a növényt ért hatásos hőmennyiség határozza meg, megfogalmaztunk egy mélynyugalmi hőösszegeket is figyelembe vevő modellt, melyet a kecskeméti rügyfakadás adatsorokra futtattuk. Összehasonlítottuk az egyszerü hőösszegmodellt (EHM) és a nyugalmi időszakban a növényt ért hideghatást is figyelembe vevő modellt (Hideghatás modell - HHM). Úgy ítéltük meg, hogy a HHM modell jobb eszköz a rügyfakadás becsléséhez, mivel a hiba, az átlagos és a maximális abszolút hiba értéke a legtöbb esetben jelentősen kisebb ennek a modellnek az esetében. A korrelációs együtthatók $\left(\mathrm{R}^{2}\right)$ szignifikánsak mindkét modellre $(\mathrm{p}<0,05)$, a HHM modellé többnyire magasabb. Chuine és munkatársai (1999) rügyfakadási modelltesztelési eredményei is kiemelték a mienkhez hasonló modellek jó alkalmazhatóságát, de hangsúlyozták, hogy a modellek jósága fajta- és régióspecifikus.

- A hideghatást is figyelembe vevő modell előnye, hogy esetében nincs olyan, az egyszerü hőösszeg-modellnél optimalizált és rögzített induló nap, mely a klímaváltozás hatására időről időre módosításra szorul.

- A mélynyugalmi időszakot is figyelembe vevő fenológiai modell átlagosan 14-15 nappal korábbra teszi a rügyfakadás idejét a 2071 utáni időszakban a vizsgált fajták esetében. Ugyanakkor a gyakorisági hisztogramok segítségével az is kiderült, hogy a rügyfakadás a melegedéssel nem csak korábbra, hanem későbbre is tolódhat, a nem kielégítő téli hideghatás következtében. A mélynyugalmi időszakot is figyelembe vevő modell (HHM) esetében az öt fajtára vonatkozó rügyfakadási időpontok a megfigyelt időszakban (19772003 ) és a referencia-időszakban (1961-1990) is átlagosan a 118. Julianus nap, az eltérés a két időszak között nem szignifikáns. A 2021-2050-es és a 2071-2100-as időszakok átlagértékei (108. és 104. Julianus nap) egymástól szignifikánsan nem térnek el, de a megfigyelt és a referencia-időszaktól már szignifikánsan különböznek $(p<0,001)$. A 
rügyfakadási idöpontok korábbra tolódása mellett a rügyfakadás idejének terjedelme is várhatóan szélesedik az időben, mely megfelel Khandauri et al. (2008) eredményeinek. Ez azt jelenti, hogy a várható extremális időjárási események következményeként akár extrém korai és extrém kései időpontok előfordulására is számíthatunk.

Az általunk vizsgált hőmérsékleti hatáson kívül számos egyedi időjárási és éghajlati tényező befolyásolja a szőlő növekedését és ezen keresztül a céltermék, a bor minőségét (pl. napsugárzás, hőakkumuláció, hőmérsékleti szélsőségek, csapadék, szél, extrém időjárási események, mint pl. a jégeső stb.). A tenyészidőszak hossza és a hőmérséklet azonban olyan kritikus tényezők, melyek különös mértékben meghatározzák a szőlő érésének folyamatát, a cukor-, sav- és színanyagtartalom kialakulását, amiből végső soron a bor minősége és jellege következik.

Az elmúlt 50 évben megfigyelt melegedés többnyire világszerte kedvezett a szőlőtermesztés minőségének, bár a jövőbeli felmelegedésnek az előrejelzések szerint globális, kontinentális és regionális szinten valószínüleg hasznos és hátrányos hatásai is lesznek (Jones, 2007). Egyrészt új területek nyílnak meg a szőlőtermesztés számára, másrészt, ezzel párhuzamosan a változások nehéz kihívások elé állítják a szőlőtermesztőket és a minőségi bortermelöket. Mindenesetre a jövőbeli éghajlatváltozás mértéke és terjedelme számos változást fog előidézni a borászati ágazatra vonatkozóan, beleértve a fokozódó nyomást a növekvő vízhiány miatt, további változásokat a szőlő fenológiájában, a szőlő és a bor összetételében, ami egyes években zavart okozva veszélyeztetheti a megszokott harmonikus aromákat. A termesztett fajták regionális-specifikus összetételének módosulása arra készteti a termelőket, hogy a szükséges változtatásokról, valamint a szőlő számára élhető területek újraértékelésével a termesztésbe bevont területek térbeli formálásáról megfontoltan döntsenek. 


\section{6. ÖSSZEFOGLALÁS}

Napjainkban egyre nagyobb érdeklödés övezi az éghajlatváltozásnak a termesztett növények, ezen belül a szőlő (Vitis vinifera L.) fenológiai fázisaira gyakorolt hatását.

A jelenleg változó és a jövőben várható körülmények feltárásához szakirodalmi gyüjtést végeztem, és összeállítottam a szőlő növényre legmarkánsabban ható 36 klímaindikátor listáját, valamint előállítottam ezek értékeit az 1977-2003 között mért kecskeméti hőmérséklet- és csapadékadatokból. A RegCM3.1 regionális klímamodell segítségével becslést végeztem az 1961-1990-es referencia-időszakra, és előrejelzést készítettem a 2021-2050, valamint a 20712100-as időszakokra. Megállapítottam, hogy a kecskeméti körzetben a 27 év alatt szignifikáns növekedés következett be számos hömérsékleti indikátor tekintetében. Az éghajlati modell becslései 2021-től az egyes hőmérsékleti indikátorok átlagértékeinek további emelkedését vetítik elő. A csapadék éves mennyisége várhatóan nem fog emelkedni. 2050 után a nyári és a tenyészidőszakban hullott csapadékmennyiség csökkenésére, valamint az őszi és téli csapadékmennyiség növekedésére kell számítanunk Kecskemét körzetében.

Kiszámítottam Kecskemétre és Helvéciára a vizsgált évek tenyészidejének hosszát kétféle, a nemzetközi szakirodalomban általánosan használt módszerrel, majd ezeket statisztikailag is összehasonlítottam. Megmutattam, hogy a klímaváltozás megfigyelhető hatásai mellett fokozottan indokolttá válik az interpolációs módszer alkalmazása, ugyanis az egyre gyakoribbá váló extrém jelenségek a hagyományos módszert pontatlanabbá teszik.

Vizsgálataink középpontjában a helvéciai és kecskeméti termőhelyről származó rügyfakadási időpontok fenológiai modelleken alapuló becslései és a jövőbeli várható változásaik előrejelzése állt.

A helvéciai kísérleti ültetvényben 5 fehérborszőlö-fajtára (Chardonnay, Rajnai rizling, Hárslevelü, Pinot blanc és Szürkebarát) és klónjaira 2000 és 2004 között felvételezett adatok alapján elvégeztem az egyszerü hőösszegzési modell (EHM) segítségével a rügyfakadás és a fővirágzás időpontjainak becslését, melynek során a bázishőmérsékletet és a hőösszeg akkumulációjának kezdeti napját optimalizáltam. A RegCM3.1 modell a 2021-2050-es időszakra Helvécián a rügyfakadás kezdetét átlagosan öt nappal előbbre, a fővirágzás kezdetét öt nappal későbbre becsüli a megfigyeltekhez képest.

A kecskeméti 1977-2003-ig terjedő 27 éves idősorra a felső bázishőmérséklettel kiegészített EHM modellt egy további, a mélynyugalmi időszak hideghatását is figyelembe vevő fenológiai modellel (HHM) hasonlítottam össze. Mindkét modell kalibrálását és validálását követően elvégeztem a rügyfakadási becsléseket a Kékfrankos, a Szürkebarát, a Hárslevelü, a Rajnai rizling és a Generosa fajtáknál. Az eredmények alapján a csupán a kényszernyugalmi időszak 
hőmérsékleteit figyelembe vevő egyszerű hőösszeg-modellnél (EHM) a mélynyugalmi időszakot is figyelembe vevő modell (HHM) pontosabb becsléseket adott a rügyfakadási időpontokra. A megfigyelt adatokhoz képest az átlagos és a maximális abszolút hiba értéke a legtöbb esetben jelentősen kisebb a HHM esetében.

A modelleket a RegCM3.1 regionális klímamodell 1961-1990-es referencia-időszakra, valamint a 2021-2050-re és a 2071-2100-as jövőbeli időszeletekre vonatkozó becsléseivel is futtattam. Az eredmények alapján elmondhatjuk, hogy 2020 után várhatóan minden fajta rügyfakadása korábbra tolódik a kecskeméti körzetben, de 2070 után a rügyfakadás idejének várható tartománya is kiszélesedik. Az egyszerü hőösszegmodell az idő előrehaladtával az öt fajta esetében átlagosan 10-11 nappal korábbra teszi a rügyfakadás kezdetét a század végére. A hideghatást is fegyelembe vevő modell átlagosan 13-17 nappal korábban jelzi a rügyfakadást a század utolsó 30 évére. 


\section{SUMMARY}

Today, there is a growing interest in the impact of climate change on phenology of crops, including grapes (Vitis vinifera L.).

In order to explore the current and the expected future conditions, I collected the 36 most important climatic indicators for grapevine and I calculated their values for the time scale 19772003 in Kecskemét region. Based on RegCM3.1 regional climate model estimations were made for the reference period 1961-1990 and projections were made for the time scales 2021-2050 and 2071-2100.

I found that the values of several temperature-indicators increased significantly in the examined 27 years in Kecskemét region. The climate model projects further increase of temperature-indicators during the $21^{\text {st }}$ century. The annual rainfall is not expected to increase. After 2050 the summer and growing season precipitation are expected to decrease while the fall and winter rainfall precipitation are expected to decrease in Kecskemét region.

I calculated and compared statistically the length of growing season with two widely used methods for the examined time periods in Kecskemét and Helvécia region. I showed that the use of the interpolation method is more reasonable, since the observed effects of climate change with increasingly frequent extreme events makes the traditional method inaccurate.

Our study focused on the phenological model based estimations and future projections for Kecskemét and Helvécia regions.

With the degree days model (GDD), optimizing the base temperature and the starting date of heat accumulation, I estimated the date of budburst and full bloom of 5 white wine grape varieties and their clones based on observed data between 2000 and 2004 in Helvécia.

The RegCM3.1 regional climate model predicted the beginning of budburst in the time period between 2021 and 2050 about five days earlier, the starting date of full bloom about five days later, compared to the data observed between 2000 and 2004.

The GDD model completed with upper base temperature was compared with an additional model (CHM) which considers the chilling effect in endodormancy concerning the 27-year time series 1977-2003 in Kecskemét region. After having calibrated and validated both models for varieties Kékfrankos, Pinot Gris, Hárslevelü, Riesling and Generosa, I estimated the budburst dates. Based on the results, we state that the simple heat-sum model (GDD) considering the temperatures of ecodormancy, only, is less effective than CHM model since the average and maximum absolute values of errors are in most cases significantly lower in case of CHM model.

Based on RegCM3.1 climate model, both GDD and CHM models were run for the reference period 1961-1990 and for the time scales 2021-2050 and 2071-2100. 
We can conclude that after 2020 a budburst shift is expected to an earlier date in Kecskemét region for all observed varieties. By the end of the $21^{\text {st }}$ century, the expected range of budburst is widening. The simple degree days model (GDD) estimates the time shift of budburst 10 to 11 days earlier while the CHM model takes the budburst dates 13-17 days earlier in the last 3 decades of the $21^{\text {st }}$ century. 


\section{KÖSZÖNETNYILVÁNÍTÁS}

Ezúton szeretnék köszönetet mondani mindazon személyeknek és intézményeknek, akik hozzájárultak a dolgozat elkészítéséhez:

Témavezetőimnek: Dr. Bisztray György Dénesnek és Dr. Ladányi Mártának, hogy irányítottak és hasznos szakmai tanácsokkal láttak el a munkám során.

Pernesz Györgynek, a Mezőgazdasági Szakigazgatási Hivatal, Szőlő-és Gyümölcs Fajtakísérleti Osztály vezetőjének a dolgozathoz nélkülözhetetlen adatokért.

Dr. Hajdu Editnek, a Kecskeméti Szőlészeti és Borászati Kutatóintézet kutatójának a további adatokért, mellyel hozzájárult a téma és az eredmények bővítéséhez.

Dr. Ferenczy Antal Zoltánnak önzetlen segítségéért, matematikai statisztikai útmutatásáért.

A BCE KeTK Szőlészeti és Borászati Intézet munkatársainak a fáradhatatlan szakmai segítségükért és támogatásukért.

Végül, de nem utolsó sorban köszönetemet szeretném kifejezni családomnak a támogatásukért, türelmükért és szeretetükért, valamint születendő gyermekemnek, aki az utolsó hónapokban jelentősen motiválta a munkámat. 


\section{IRODALOMJEGYZÉK}

[1] Aerts, R., Cornelissen, J. H. C., Dorrepaal, E., Van Logtestijn, R. S. P., Callaghan, T. V. (2004): Effects of experimentally imposed climate scenarios on flowering phenology and flower production of subarctic bog species. Glob Chang Biol 10(9): 1599-1607.

[2] Allen Consulting Group (2005): Climate change, risk and vulnerability. Promoting an efficient adaptation response in Australia. Final Report, March 2005.

[3] Alleweldt, G. (1963): Einfluss von klimafaktorem die Zahl der Inflorescenzen bei Reben. Wein-Wiss 18(2):61-70.

[4] Amerine, M.A., Winkler, A. J. (1944): Composition and quality of musts and wines of California grapes. Hilgardia, 15:493-675.

[5] Andersen, T. B. (1991): A model to predict the beginning of the pollen season. Grana 30, $269-275$.

[6] Arakawa, H. (1955): Twelve centuries of blooming dates of the cherry blossoms in the city of Kyoto and its own vicinity. Geophysica Pura e Applicata 30: 147-150.

[7] Arakawa, H. (1956): Climatic change as revealed by the blooming dates of the cherry blossoms at Kyoto. Journal of Meteorology 13: 599-600.

[8] Arft, A. M., Walker M. D., Gurevitch, J., Alatalo, J. M., Bret-Harte, M. S., Dale, M., Diemer, M., Gugerli, F., Henry, G. H. R., Jones, M. H., Hollister, R. D., Jo' Nsdo' Ttir, I. S., Laine, K., Le' Vesque, E., Marion, G. M., Molau, U., M ølgaard, P., Nordenhäll, U., Raszhivin, V., Robinson, C. H., Starr, G., Stenström, A., Totland, Ø., Turner, P. L., Walker, L. J., Webber, P. J., Welker, J. M., Wookey, P. A. (1999): Responses of tundra plants to experimental warming: Meta-analysis of the international tundra experiment. Ecol. Monogr. 69, 491-511

[9] Arrhenius, S. (1896): On the Influence of Carbonic Acid in the Air upon the Temperature of the Ground. Philosophical Magazine and Journal of Science. Series 5, 41, 237-276

[10] Bach, W. (1987): Development of climate change scenarios: A. From general circulation models. In The Impact of Climatic Variations on Agriculture, Vol I: Assessment in Cool Temperature and Cold Regions (eds M.L. Parry, T.R. Carter, \&. NT. Konijn), pp. 125-157. Kluwer Academic Publishers. Dordrecht.

[11] Baggiolini, M. (1952) : Les stades repčres dans le développement annuel de la vigne el leur utilisation practique, Rev. Romande d'Agriculture de Viticulture et d'Arboriculture, 8, 4-6.

[12] Baillod, M., Baggiolini, M. (1993): Les stades repérés de la vigne et leur utilisation pratique. Rev. Suisse Vitic. Arboric. Hortic. 25, 7-9. 
[13] Bartholy, J., Pongrácz, R., Matyasovszky, I., Schlanger, V. (2004): A XX. században bekövetkezett és a XXI. századra várható éghajlati tendenciák Magyarország területére, In: AGRO-21 Füzetek, 2004/33: 1-18.

[14] Bartholy, J., Mika, J. (2005): Időjárás és éghajlat - cseppben a tenger? Magyar Tudomány. 7, 789-796.

[15] Bartholy, J., Pongrácz, R., Barcza, Z., Haszpra, L., Gelybó, Gy., Kern, A., Hidy, D., Torma, Cs., Hunyady A., Kardos, P. (2007): A klímaváltozás regionális hatásai: a jelenlegi állapot és a várható tendenciák. - Földrajzi Közlemények. CXXXI. (LV.) kötet, 4. szám, pp. 257-269.

[16] Bartholy, J., Pongrácz, R., Torma, Cs. (2010): A Kárpát-medencében 2021-50-re várható regionális éghajlatváltozás RegCM-szimulációk alapján. - "KLÍMA-21” Füzetek, 60: 313.

[17] Bartholy, J., Pongrácz, R., Torma, Cs., Pieczka, I., Kardos, P., Hunyady, A. (2009): Analysis of regional climate change modelling experiments for the Carpathian basin. International Journal of Global Warming 1, 238-252.

[18] Beattie, A. J., Breedlove, D. E., Ehrlich, P. R. (1973): The ecology of pollinators and predators of Frasera speciosa. Ecology 54:81-91.

[19] Beaubien, E., Hamann, A. (2011): Spring Flowering Response to Climate Change between 1936 and 2006 in Alberta, Canada. BioScience 61: 514-524. ISSN 0006-3568, electronic ISSN 1525-3244.

[20] Bényei F., Lőrincz, A. (2005): Borszőlőfajták, csemegeszőlö-fajták és alanyok. Fajtaismeret és használat. Mezőgazda Kiadó. Budapest.

[21] Bényei F., Lőrincz, A., Sz. Nagy, L. (1999): Szőlőtermesztés. Mezőgazda Kiadó. Budapest.

[22] Bidabe, B. (1965a): Contrôle de l'époque de floraison du pommier par une nouvelle conception de l'action de températures. C R Acad Agric Fr 49:934-945.

[23] Bidabe, B. (1965b): L'action des températures sur l'évolution des bourgeons de l'entrée en dormance à la floraison. 96 Congrès Pomologique, pp 51-56.

[24] Bindi, M., Miglietta, F., Gozzini, B., Orlandini, S., Seghi, L. (1997 a): A simple model for simulation of growth and development in grapevine (Vitis vinifera L.). I. Model description. Vitis 36(2):67-71.

[25] Bindi, M., Miglietta, F., Gozzini, B., Orlandini, S., Seghi, L. (1997 b): A simple model for simulation of growth and development in grapevine (Vitis vinifera L.). II. Model validation. Vitis 36(2):73-76. 
[26] Bishop, J. G., Schmeske, D. W. (1998): Variation in flowering phenology and its consequences for lupines colonizing Mount St Helens. Ecology 79:534-546.

[27] Bisztray, Gy. D., Cindrić, P., Hajdu, E., Ivaniśević, D. Korać, N., Lázár, J., Medić, M., Szegedi, E. (eds Hajdu, E.) (2011): Szőlőfajták, szaporítóanyaguk és betegségeik. Agroinform Kiadó, Budapest. ISBN 978-963-502-940-2.

[28] Bootsma, A., Gameda, S., Mckenney, D. W. (2005a): Impacts of potential climate chae os selected agroclimatic indices in Atlantic Canada Canadian Journal of Soil Science Volume 85, Issue 2, May 2005, Pages 329-343.

[29] Bootsma, A., Gameda, S., Mckenney, D. W. (2005 b): Potenial impacts of climate change on corn, soybeans and barley yields in Atlantic Canada Canadian Journal of Soil Science Volume 85, Issue 2, May 2005, Pages 345-357.

[30] Bonhomme, R. (2000): Bases and limits to using "degree-day" units. Eur. J. Agron. (13):1-10, doi:10.1016/S1161-0301(00)00058-7.

[31] Borvidéki értesítő (2003): Kunsági Borvidék Hegyközségi Tanácsa, Kecskemét, 2003/2.

[32] Bos, P.R. (1893): Phyto-phenological observations in The Netherlands. Tijdschift van het Koninklijk Nederlands Aardrijkskundig Genootschap, 409^12 (In Dutch).

[33] Boss, P. K., Elise, J., Buckeridge, A. P., Thomas, M. (2003): New insights into grapevine flowering. Funct Plant Biol 30:593-606.

[34] Botos, E. P., Hajdu, E. (2004): A valószínűsíthető klímaváltozás hatásai a szőlő- és bortermelésre. "AGRO-21“"Füzetek, 34: 61-73.

[35] Boyer, W. D. (1973): Air temperature, heat sums, and pollen shedding phenology of longleaf pine. Ecology 54, 421-425.

[36] Bradley, N. L., Leopold, A. C., Ross, J., Huffaker, W. (1999): Phenological changes reflect climate change in Wisconsin. Proceedings of the National Academy of Sciences 96: 97019704.

[37] Bradshow, A. D., McNeilly, T. (1991): Evolutionary response to global change. Ann Bot 67:5-14.

[38] Branas, J., Bernon, G., Levadoux, L. (1946): Eléments de viticulture générale. Montpellier.

[39] Broecker, W. S. (1987): The Biggest Chill. Natural History Magazine. 97, 74-82.

[40] Bruggen van, A. H. C., Semenov, A. M. (1999): A new approach to the search for indicators of root disease suppression. Australasian Plant Pathology. 28, 4-10.

[41] Cahill, K. N., Lobell, D. B., Field, C. B., Bonfils, C., Hayhoe, K. (2007): Modeling climate change impacts on wine grape yields and quality in California http://chaireunescovinetculture.u-bourgogne.fr/Actes\%20clima/Actes/Article_Pdf/Cahill.pdf 
[42] Callendar, G. S. (1938): The Artifical Production of Carbon Dioxide and Its Influence on Temperature. Quarterly Journal of Royal Meteorological Society. 64, 223-240.

[43] Cannell, M. G. R., Smith, R. I. (1983): Thermal time, chill days and prediction of budburst in Picea sitchensis. J. Appl. Ecol. (20): 951-963.

[44] Cannell, M. G. R., Smith, R. I. (1986): Climatic warming, spring budburst and frost damage on trees. Journal of Applied Ecology 23: 177 \pm 191 .

[45] Carbonneau, A., Riou, C., Guyon, D., Riom, J., Schneider, C. (1992): Agrométéorologie de la vigne en France. EUR-OP, Luxembourg, p 168. Bonhomme R (2000) Bases and limits to using “degree-day” units. Eur. J. Agron. (13):1-10, doi:10.1016/S1161-0301(00)000587.

[46] Carter, T. R., Parry, M. L., Porter, J. H. (2007): Climatic change and future agroclimatic potential in Europe. International Journal of Climatology, 11. 3, P. 251- 269.

[47] Cattivelli, L., Bartlet, D. (1992): Biochemical and molecular biology of cold-inducible enzymes and proteins in higher plants. In: Wray, J. L. (ed) Society for experimental biology seminar series 49: Inducible plant proteins. Cambridge University Press, Cambridge, UK.

[48] Cecich, R. A., Kang, H., Chalupka, W. (1994): Regulation of early flowering in Pinus banksiana. Tree Physiology 14, 275-284.

[49] Champagnat, P. (1983): Quelques réflexions sur la dormance des bourgeons des végétaux ligneux. Physiologie Végétale 21: $607 \pm 618$.

[50] Champagnol, F. (1984): Eléments de physiologie de la vigne et viticulture générale. Champagnol, Saint-Gely-du-Fesc, France.

[51] Chuine, I., Cour, P. és Rousseau, D. D. (1998): Fitting models predicting dates of flowering of temperate-zone trees using simulated annealing. Plant, Cell and Environment $21,455-466$.

[52] Chuine, I., Cour, P., Rousseau, D. D. (1999): Selecting models to predict the timing of flowering of temperate trees: implications for tree phenology modelling. Plant, Cell Environ. (22): 1-13.

[53] Chuine, I., Cour, P. (1999): Climatic determinants of budburst seasonality in four temperate-zone tree species. New Phytologist, 143:339-349.

[54] Chuine, I. (2000): A unified model for budburst of trees. J. Theor. Biol. (207):337-347, doi:10.1006/jtbi.2000.2178.

[55] Chuine, I. és Beaubien, E. (2001): Phenology is a major determinant of tree species range. Ecology Letters, (2001) 4: 500-510. 
[56] Chuine, I., Kramer, K., Hänninen, H. (2003): Plant development models. In Phenology: An Integrative Environmental Science (Schwartz, M.D., ed.), pp. 217-235, Kluwer.

[57] Chuine, I., Yiou, P., Viovy, N., Seguin, B., Daux, V., Ladurie LeRoy, E. (2004): Grape ripening as a past climate indicator. Nature, 432, 289-290.

[58] Cleland, E. E., Chuine, I., Menzel, A., Mooney, H. A., Schwartz, M. D. (2007): Shifting plant phenology in response to global change. Trends in Ecology and Evolution, Volume 22, No. 7.

[59] Coombe, B. G. (1995): Adoption of a system for identifying grapevine growth stages. Australian Journal of Grape and Wine Research. 1(2), 104-110.

[60] Cortázar-Atauri, G.I., Brisson, N., Seguin, B., Gaudillere J.P., Baculat, B. (2005): Simulation of budbreak date for vine. The BRIN model. Some applications in climate change study. In: Proceedings of XIV International GESCO Viticulture Congress, Geisenheim, Germany, 23-27 August, 2005, pp 485-490.

[61] Cortázar-Atauri, G.I., Brisson, N., Gaudillere, J.P. (2009): Performance of several models for predicting budburst date of grapevine (Vitis vinifera L.) Int. J. Biometeorol DOI 10.1007/s00484-009-0217-4.

[62] Czelnai Rudolf (1999): Világóceán. Modern fizikai oceanográfia. Vince, Budapest.

[63] Csepregi, P., Zilai, J. (1988): Szőlőfajta-ismeret és -használat. Mezőgazdasági Kiadó, Budapest.

[64] Csepregi, P. (1997): Szőlőtermesztési ismeretek. Mezőgazda Kiadó, Budapest.

[65] De Jong, P. W., Brakefield, P. M. (1998): Climate and change in clines for melanism in the two-spot ladybird, Adalia bipunctata (Caleoptera: Coccinellidae). Proc R Soc Lond B Biol Sci B265:39-43.

[66] Deutsche Wetterdienst (1991): Anleitung für die phaenologischen Beobachter des Deutscher Wetterdienstes, Nr. 17, Deutsche Wetterdienst Zentralamt, Offenbach am Main (In German).

[67] Diós, N., Hufnagel, L., Szenteleki, K., Ferenczy, A., Petrányi, G. (2009): A Climate Profile Indicator Based Comparative Analysis of Climate Change Scenarios with Regard to Maize (Zea mays L.) Cultures. Applied Ecology and Environmental Research. 783 pp. 199-214.

[68] Dookazalian, N. K. (1999): Chilling temperature and duration interact on the budbreak of 'Perlette' grapevine cuttings. HortScience 34:1054-1056.

[69] Dookazalian N. K., Williams L. E. (1995): Chilling exposure and hydrogen cyanamide interact in breaking dormancy of grape buds. HortScience 30:1244-1247.

[70] Dry, P., Smart, R. E. (1988): The grapegrowing regions of Australia. Viticulture. Volume 1. Resources., Coombe, B. G. and P. Dry, eds., Winetitles, Adelaide. 
[71] Dunkel, Z., Kozma, F., Major, Gy. (1981): Szőlöültetvényeink hőmérséklet- és sugárzásellátottsága a vegetációs időszakban. Időjárás, 85 (4): 226-234.

[72] Dunne, J. A., Harte, J., Taylor, K. J. (2003): Subalpine meadow flowering phenology responses to climate change: integrating experimental and gradiant methods. Ecol Monogr 73:69-86.

[73] Eichorn, K. W., Lorenz, D. H. (1977): Phänologische Entwicklungsstadien der Rebe. Nachrichtenblatt des dt. Pflanzenschutzdienstes (Braunschweig), 29:119-120. p.

[74] English-Loeb, G. M., Karba, R. (1992): Cosequences of variation in flowering phenology for seed head herbivory and reproductive success in Erigeron glaucus (Compositae). Oecologia 89:588-595.

[75] Erdélyi, É., Ferenczy, A., Boksay, D. (2008): A klímaváltozás várható hatása a kukorica és a búza fenofázisainak alakulására. Klíma-21 füzetek 53, 115-130.

[76] Erdélyi, É., Gaál, M., Horváth, L. (2009): Climate change impacts in agriculture and possible responses. CIGR Section V International Symposium 2009 - Technology and Management to Increase the Efficiency in Sustainable Agricultural Systems. 1- 4. September 2009, Rosario, Argentina.

[77] Erdélyi, É. (2009): Benefit and detriment of changing climate in crop production. Workshop on Modelling and Measuring Aspects of some Environmental Issues in European Union and National Projects. 2009 április, Novi Sad, Serbia.

[78] Erez, A. (1987): Chemical control of bud break. HortScience 22:1240-1243.

[79] Erez, A., Lavee, S. (1974): Recent advances in breaking the dormancy of deciduous fruit trees. In: Proc 19th Intl Hort Congress, Warszawa. 3:69-78 Faust, M., Erez, A., Rowland, I. J., Wang, S.Y., Norman, H. A. (1997): Bud dormancy in perennial fruit trees: physiological basis for dormancy induction, maintenance, and release. HortScience 32:623-628.

[80] Estrella, N. és Menzel, A. (2006): Responses of leaf colouring of four deciduous tree species to climate and weather in Germany. Climate Res. 321, 253-267.

[81] Farmer, R. E. (1968): Sweetgum dormancy release: effects of chilling, photoperiod, and genotype. Physiologia Plantarum 21, 1241-1248.

[82] Fregoni, C., Pezzutto, S. (2000): Principes et premières approches de l'indice bioclimatique de qualité de Fregoni. Progr. Agric. Vitic. 18, 390-396.

[83] Frenguelli, G., Bricchi, E., Romano, B., Ferranti, M. F. és Antognozzi, E. (1992): The role of air temperature in determining dormancy release and flowering of Corylus avellana L. Aerobiologia 8, 415-418. 
[84] Galen, C., Stanton, M. L. (1991): Consequences of emergences phenology for reproductive success in Ranonculus adoneus (Ranunculaceae). Am J Bot 78:978-988.

[85] Galen, C., Stanton, M. L. (1993): Short-term responses of alpine buttercups to experimental manipulations of growing season length. Ecology 74:1052-1058.

[86] Geber, M. A., Dawson, T. E. (1993): Evolutionary responses of plants to global change. In Kareiva, P. M., Kingsolver, J. G., Huey, R. B. (eds) Biotic interactions and global change. Sineauer, USA, pp 179-197.

[87] Giorgi, F., Marinucci, M. R., Bates, G. T. (1993): Development of a second generation regional climate model (RegCM2) i: Boundary layer and radiative transfer processes, Mon. Wea. Rev., 121, 2794-2813.

[88] Gladstones, J. (1992): Viticulture and Environment. Winetitles, Adelaide, South Australia.

[89] Gladstones, J. (2000): Past and future climatic indices for Viticulture. Paper presented at 5th International Symposium for Cool Climate Viticulture and Oenology, Melbourne, Australia, January 16-20.

[90] Goudriaan, J., Zadoks, J. C. (1995): Global climate change: modeling the potential responses of agro-ecosystems with special reference to crop protection. Environ.Pollut. 87, pp. 215-224.

[91] Greven, M., Green, S., Neal, S., Clothier, B. (2007): Potential impact of climate change on water use and management in grapes. XXX. World Congress of Vine and Wine. 10-16. June. 2007. Budapest, Hungary. (CD ROM)

[92] http://www.oiv2007.hu/documents/viticulture/MGreven_The_potential_influence_of_clim ate_change_on_vine_water_use_FINAL.pdf

[93] Gross, R. S., Werner, P. A. (1983): Relationships among flowering phenology, insect visitors and seed set individuals: experimental studies of four co-occuring species of goldenord (Solidago compositae). Ecol Monogr 53:95-117.

[94] Hajdu, E., Saskői, B.-né (2009): Abiotikus stresszhatások a szőlő életterében Agroinform Kiadó, Budapest, p. 222.

[95] Happ, E. (1999): Indices for exploring the relationship between temperature and grape and wine flavour. The Australian and New Zealand Wine Industry Journal 14(4): 68-75.

[96] Harnos, Zs., Ladányi, M. (2005): Biometria agrártudományi alkalmazásokkal. Budapesti Corvinus Egyetem. Aula Kiadó, Budapest.

[97] Harnos, Zs., Gaál, M., Hufnagel, L. (2008): Klímaváltozásról mindenkinek. Budapesti Corvinus egyetem, Kertészettudományi Kar, Matematika és Informatika Tanszék, Budapest. 
[98] Haszpra, L., Barcza, Z. (2005): Légköri szén-dioxid mérések Magyarországon. Magyar Tudomány. 1, 104-112.

[99] Häkkinen, R., Linkosalo, T. és Hari, P. (1995): Methods for combining phenological time series: application to bud burst in birch (Betula pendula) in Central Finland for the period 1896-1955. Tree Physiology 15, 721-736.

[100] Hänninen, H. (1990): Modelling bud dormancy release in trees from cool and temperate regions. Acta Forestalia Fennica 213, 1-47.

[101] Hänninen, H. (1991): Does climatic warming increase the risk of frost damage in northern trees? Plant, Cell Environ. (14): 449-454.

[102] Hänninen, H., Backman, R. (1994): Rest break in Norway spruce seedlings: test of a dynamic temperature response hypothesis. Canadian Journal of Forest Research (24): 558563.

[103] Hänninen, H. (1995): Effects of climatic change on trees from cool and temperate regions: an ecophysiological approach to modelling of budburst phenology. Canadian Journal of Botany 73, 183-199.

[104] Hänninen, H. (1996): Effects of climatic warming on northern trees: testing the frost damage hypothesis with meteorological data from provenance transfer experiments. Scandinavian Journal of Forestry Research 11: 17 \pm 25 .

[105] Hänninen, H., Kellomäki, S., Laitinen, K., Pajari, B., Repo, T. (1993): Effect of increased winter temperature on the onset of height growth of Scots pine: a field test of a phenological model. Silva Fennica 27: 251 \pm 257 .

[106] Hänninen, H., Leinonen, I., Repo, T. Kellomäki, S. (1996): Overwintering and productivity of Scots Pine in a changing climate. Silva Fennica 30, 2-3.

[107] Haywood, J., Boucher, O. (2000): Estimates of the direct and indirect radiative forcing due to tropospheric aerosols: a review. Reviews of Geophysics, 38, 4. pp. 513-543.

[108] Heide, O. M. (1993): Daylength and thermal time responses of budburst during dormancy release in some northern deciduous trees. Physiologia Plantarum 88, 531-540.

[109] Holfman, A. A., Parson, P. A. (1997): Extreme environmental change and evolution. Cambridge University Press, Cambridge.

[110] Hong, X. C., Mitchell, J. F. B., Lavery, J. R. (1992): Simulated Diurnal Range and Variability of SDurface Temperature in a Global Climate Model for Present and Doubled CO2 Climates, Hadley Center for Climate Prediction and Research, UK.

[111] Hughes, L. (2000): Biological consequences of global warming: is the signal already apparent? Trends Ecol Evol 15:56-61. 
[112] Huglin, P. (1978): Nouveau Mode d'Évaluation des Possibilités Héliothermiques d'un Milieu Viticole. C. R. Acad. Agr. France, 1117-1126.

[113] Huglin, P. (1986): Biologie et écologie de la vigne. Ed. Payot, Lausanne - Paris.

[114] Hunter, A. F. és Lechowicz, M. J. (1992): Predicting the timing of budburst in temperate trees. Journal of Applied Ecology 29, 597-604.

[115] Intergovernmental Panel on Climate Change (IPCC) (2001): Third assessment report climate change. In McCarthy JJ, Canziani OF, Leary NA, Dokken DJ, White KS (eds) Impacts, adaptation and vulnerability. Cambridge University Press, Cambridge.

[116] Intergovernmental Panel on Climate Change (IPCC) (2007): Impacts, Adaptation and Vulnerability: Working Group II Contribution to the IPCC. Fourth Assessment Report: Summary for Policymakers. IPCC Secretariat, Geneva, Switzerland.

[117] Jackson D. I., Lombard, P. B. (1993): Environmental and management practices affecting grape composition and wine quality: a review. Am. J. Enol. Vitic. 4, 409-430.

[118] Jones, G. V., Davis, R. E. (2000 a): Using a synoptic climatological approach to understand climate-viticulture relationships. International Journal of Climatology, 20, pp. 813-837.

[119] Jones, G. V., Davis, R. E. (2000 b): Climate Influences on Grapevine Phenology, Grape Composition, and Wine Production and Quality for Bordeaux, France. Am. J. Enol. Vitic., Vol. 51, No. 3. pp. 249-261.

[120] Jones, G. V., Storchmann, K-H. (2001) Wine market prices and investment under uncertainty: an econometric model for Bordeaux Crus Classés. Agricultural Economics 26 (2001) pp. 115-133.

[121] Jones, G.V. (2003): Winegrape phenology. In: Schwartz MD (ed) Phenology: an integrative environmental science. Kluwer, Milwaukee, pp. 523-540.

[122] Jones, G. V., White, M. A., Cooper, O. R., Strochmann, K. (2005 a): Climate change and global wine quality. Climatic Change, 73(3):319-343.

[123] Jones, G.V., Duchene, E., Tomasi, D., Yuste, J., Braslavksa, O., Schultz, H., Martinez, C., Boso, S., Langellier, F., Perruchot, C., and G. Guimberteau (2005): Changes in European Winegrape Phenology and Relationships with Climate, GESCO 2005. August 2005.

[124] Jones, G. V. (2007): Climate Change: Observations, Projections, and General Implications for Viticulture and Wine Production. Practical Winery and Vineyard, July/August 44-64.

[125] Jones, G. V., Goodrich, G.B., (2008): Influence of Climate Variability on Wine Region in the Western USA and on Wine Quality in the Napa Valley. Climate Research, 35: 241254. 
[126] Jones, G.V., Moriondo, M., Bois, B., Hall, A., Duff, A. (2009): Analysis of the spatial climate structure in viticulture regions worldwide. Le Bulletin de l'OIV 82(944,945,946):507-518.

[127] Kadir, S. A., Proebsting, E. L. (1994): Screening sweet cherry selections for dormant floral bud hardiness. HortScience 29:104-106.

[128] Kádár, Gy. (1998): Az évjárat hatása a szőlő és a bor minőségére az Alföldi borvidéken. In: DIÓFÁSI, L., Magyarország besorolhatósága az EU jelenlegi borter- melési régióiba. Az új bortermelő régió kialakításának szakmai feltételei. Hatástanulmány. 141. pp.

[129] Katz, R. W. (1988): Statistical procedures for making inferences about climate variability. Journal of Climate, 1057-1064.

[130] Keeling, C. D., Chin, J. F. S., Whorf, T. P. (1996): Increased activity of northern vegetation inferred from atmospheric CO2 measurements. Nature 382:146-149.

[131] Kellett, B. M., Bristow, K. L. and Charlesworth, P. (2005): Indicator frameworks for assessing irrigation sustainability. Technical Report 05/01. 52 pp. http://www.clw.csiro.au/publications/technical2005/tr01-05.pdf

[132] Khanduri, V. P., Sharma C. M., Singh, S. P. (2008): The effects of climate change on plant phenology. Environmentalist 28:143-147 DOI 10.1007/s10669-007-9153-1.

[133] Kliewer, W. M. (1973): Berry composition of Vitis vinifera cultivars as influenced by photo and nycto-temperatures during maturation. J. Am. Soc. Hort. Sci. 2, 153-159.

[134] Kliewer, W. M., Torres, R. E. (1972): Effect of controlled day and night temperatures on grape coloration. Am. J. Enol.Vitic. 2, 71-77.

[135] Koocheki, A., Nasiri, M., Kamali, G. A., Shahandeh, H. (2006): Potential impacts of climate chane on aroclimatic indicators is Iran. Arid Land Research and Managment. Volume 20, Issue 3, '1 September 2006, Pages 245-259.

[136] Kozma, P. (1991): A szőlő és termesztése I. A szőlőtermesztés történeti, biológiai és ökológiai alapjai. Akadémiai Kiadó. Budapest.

[137] Kramer, K. (1994 a): A modelling analysis of the effects of climatic warming on the probability of spring frost damage to tree species in The Netherlands and Germany. Plant, Cell and Environment 17: $367 \pm 377$.

[138] Kramer, K. (1994 b) Selecting a model to predict the onset of growth of Fagus sylvatica. Journal of Applied Ecology 31, 172-181.

[139] Kramer, K. (1995): Phenotypic plasticity of the phenology of seven European tree species in relation to climatic warming. Plant, Cell and Environment 18: 93 \pm 104 . 
[140] Kramer, K., Friend, A., Leinonen, I. (1996): Modelling comparison to evaluate the importance of phenology and spring frost damage for the effects of climate change on growth of mixed temperate-zone deciduous forests. Climate Research 7: $31 \pm 41$.

[141] Kramer, K., Mohren, G. M. J. (1996): Sensitivity of FORGRO to climatic change scenarios: a case study on Betula pubescens, Fagus sylvatica and Quercus robur in the Netherlands. Climatic Change 34: 231 237.

[142] Lacey, E., Pace, R. (1983): Effect of flowering and dispersal times on offspring fate in Daucus carota (Apiaceae). Oecologia 60:274-278.

[143] Ladányi, M. (2006): Folyamatszemléleti lehetőségek az agro-ökoszisztémák modellezésében. Doktori (Ph.D.) értekezés. Budapesti Corvinus Egyetem.

[144] Ladányi, M., Hlaszny, E. (2010): Modellek vallanak a klímaváltozásról és hatásairól. Agrofórum 21 (7):98-101.

[145] Landsberg J.J. (1974): Apple fruit bud development and growth; analysis and an empirical model. Annals of Botany 38, 1013-1023.

[146] Lang, G. A., Early, J. D., Martin, G. C., Darnell, R. L. (1987): Endo-, para-, and ecodormancy: physiological terminology and classification for dormancy research. HortScience 22(3):371-377.

[147] Larcher, W. (1995): Physiological plant ecology. Springer, Berlin.

[148] Lavee, S., May, P. (1997): Dormancy of grapevine buds. Aust J Grape Wine Res 3:31-46.

[149] Liennard, M. E. (2002): Contribution ŕ l'étude de la prévision de la précocité de floraison et du déterminisme climatique des nécroses florales de l'Abricotier, Prunus armeniaca L., dans le contexte des changements climatiques. Institut National d'Horticulture, Angers.

[150] Li, H., You, J., Huo, X. (2007): The effect of global warming on Chinese viticulture. 30th World Congress of Vine and Wine. 10-16 June, 2007, Budapest, Hungary.

[151] Lieth, H. (1971): The phonological viewpoint in productivity studies. In: UNESCO, eds. Productivity of forest ecosystems. Paris, France: UNESCO, 71-83.

[152] Lorenz, D.H. Eichhorn, K. W., Bleiholder, H., Klose, R., Meier, U., Weber, E. (1994): Phänologische Entwicklungsstadien der Weinrebe (Vitis vinifera L. ssp. vinifera). Vitic. Enol. Sci. 49: 66-70.

[153] Matsumoto, K., Ohta, T., Nakamura, T. (2003): Climate change and extension of the Gingko biloba L. growing season in Japan. Glob Chang Biol 7:657-666.

[154] Mauget, J. C. (1977): Dormance des bourgeons végétatifs de Noyer (Juglans regia L.) cultivés sous différentes conditions climatiques. Comptes Rendus de l'Académie des Sciences, Série D 284: 2351 \pm 2354 . 
[155] Mauget, J. C. (1983): Etude de la levée de dormance et du débourrement des bourgeons de noyer (Juglans regia L., cv. 'Franquette') soumis à des températures supérieures à $15^{\circ} \mathrm{C}$ au cours de leur période de repos apparent. Agronomie 3, 745-750.

[156] McCarthy, J. P. (2001): Ecologycal consequences of recent climate change. Conserv Biol 15(2) 320-331.

[157] Menzel, A., Fabian, P. (1999): Growing season extended in Europe. Nature 397:659.

[158] Menzel, A. (2000): Trends in phenological phases in Europe between 1951-1996. Int J Biometeorol 44:76-81.

[159] Menzel, A., Estrella, N. (2001): Plant phenological changes In Walther, G. R., Burga, C. A., Edwards, P. J. (eds) Fingerprints of climatic change-Adapted behaviour and shifting species Ranges. Kluwer Academic/Plenum, New York, pp 123-137.

[160] Menzel, A. (2003): Plant phenological anomalies in Germany and their relation to air temperature and NAO. Climatic Change 57, 243-263.

[161] Menzel, A., Sparks T. H., Estrella N., Koch, E., Aasa, A., Ahas, R., Alm-Kübler, K., Bissolli, P., Braslavská, O., Breide, A., Chmielewski, F. M., Crepinsek, Z., Curnel, Y., Dahl, Å, Defila, C., Donnelly, A., Filella, Y., Jatczak, K., Måge, F., Mestre, A., Nordli, Ө., Peňuelas, J., Pirinen, P., Remisová, V., Scheifinger, H., Striz, M., Susnik, A., van Vliet, A. J. H., Wielgolaski, F. E., Zach, S., Zust, A. (2006): European phenological response to climate change matches the warming pattern. Global Change Biol. 12, 1969-1976.

[162] Mika, J. (1988): A globális felmelegedés regionális sajátosságai a Kárpát-medencében. Időjárás 92; 178-189. p.

[163] Mika, J. (1991): A nagyobb globális felmelegedés várható magyarországi sajátosságai. Időjárás 95, 265-278. p.

[164] Mitchell, J. F. B. (1989): The "greenhouse" effect and climate change. Reviews of Geophysics 27(1), 115-139.

[165] Moncur, M. W., Rattigan, K., Mackenzie, D. H., McIntyre, G. N. (1989): Base temperatures for budbreak and leaf appearance of grapevines. Am J Enol Vitic 40(1):2126.

[166] Morin, X., Chuine, I. (2005): Sensitivity analysis of the tree distribution model PHENOFIT to climatic input characteristics: implications for climate impact assessment. Global Change Biology (2005) 11, 1493-1503, doi: 10.1111/j.1365-2486.2005.00996.x

[167] Murray, M. B., Cannell, M. G. R., Smith, R. I. (1989): Date of budburst of fifteen tree species in Britain following climatic warming. Journal of Applied Ecology 26: 693 \pm 700 .

[168] Murray, M. B., Smith, R. I., Leith, I. D., Fowler, D., Lee, H. S. J., Friend, A. D., Jarvis, P. G. (1994): Effects of elevated $\mathrm{CO}_{2}$, nutrition and climatic warming on bud phenology in 
Sitka (Picea sitchensis) and their impact on the risk of frost damage. Tree Physiology $14: 691 \pm 706$.

[169] Myking, T. és Heide, O. M. (1995): Dormancy release and chilling requirements of buds of latitudinal ecotypes of Betula pendula and B. pubescens. Tree Physiology 15, 697-704.

[170] Myneni, R. B., Keeling, C. D., Tucker, C. J., Asrar, G., Nemani, R. R. (1997): Increased plant growth in the northern high latitudes from 1981 to 1991. Nature 386:698-702.

[171] NASA, Earth Observing System (1999): Volcanoes and Climate Effects of Aerosols. Lead authors: Hartmann, D. L., Mouginis-Mark, P. http://eospso.gsfc.nasa.gov

[172] Nelson, E., A., Lavender, D.,P. (1979): The chilling requirement of western hemlock seedlings. Forest Science 25, 485-490.

[173] New, M., Hulme, M., Jones, P. D. (1999): Representing twentieth century space-time climate variability. Part 1: development of a 1961-90 mean monthly terrestrial climatology. Journal of Climate 12, 829-856.

[174] Németh, M. (1970): Ampelográfiai album. Termesztett borszőlőfajták 2. Budapest: Mezőgazdasági Kiadó. 276 p.

[175] Nicholas, P. (Comp. \& Ed.). (2004): Soil, irrigation and nutrition. In Grape Production Series: No. 2. Adelaide: South Australian Resource and Development Institute.

[176] Nicholas, P., Magarey, P. Wachtel, M. (1994): Diseases and pests. Grape Production Series, Winetitles, Adelaide, 106.

[177] Nienstaedt, H. (1966): Dormancy and dormancy release in white Spruce. Forest Science 12: $374 \pm 384$.

[178] Nigond, J. (1967): Recherches sur la dormance de la vigne. Ann Amelior Veget 9:I:107152 II:197-232; III:273-338.

[179] Nizinski, J. J., Saugier, B. (1988): A model of leaf budding and development for a mature Quercus forest. Journal of Applied Ecology 25, 643-652.

[180] Oliveira, M. (1998): Calculation of budbreak and flowering base temperatures for Vitis vinifera cv. Touriga Francesa in the Douro Region of Portugal. Am J Enol Vitic 49(1):7478. Proceedings of XIV International GESCO Viticulture Congress, Geisenheim, Germany, 23-27 August, 2005, pp 485-490.

[181] Or, E., Nir, G., Vilozny, I. (1999): Timing of hydrogen cyanamide application to grapevine buds. Vitis 38:1-6

[182] Or, E. (2009): Grape bud dormancy release - the molecular aspect. Department of Fruit Tree Sciences, Institute of Horticulture, Agricultural Research Organization, The Volcani Center, Bet Dagan 50250, Israel. 
[183] Parmesan, C., Yohe, G. (2003): A globally coherent fingerprint of climate change impacts across natural systems. Nature 421:37-42.

[184] Passioura, J. D. (1973): Sense and nonsense in crop simulation. J. Aust. Inst. Agric. Sci. 39. pp. 181-183.

[185] Penuelas, J., Finella, I. (2001): Phenology: responses to a warming world. Science 294:793-794.

[186] Penuelas, J. et al. (2004): Complex spatiotemporal phenological shifts as a response to rainfall changes. New Phytol. 161, 837-846.

[187] Pernesz, Gy. (2004): New resistant table grape cultivars bred in Hungary Proceedings of the First International Symposium on Grapewine Growing, Commerce and Research, Acta Horticulturae (652): 321.

[188] Perry, T.O. és Wang, L.W. (1960): Genetic variations in the winter chilling requirement for date of dormancy break for Acer robur. Ecology 41, 790-794.

[189] Perry, T. O. (1971): Dormancy of trees in winter. Science 171: 29 \pm 36 .

[190] Peterson, M. A. (1997): Host plant phenology and butterfly dispersal: causes and consequences of uphill movement. Ecology 78:167-180.

[191] Peynaud, E., Ribéreau-Gayon, J. (1971): The grape. In: The biochemistry of fruits and their products. Vol. II. Ed by Hulme AC, Academic Press, London and New York.

[192] Pongrácz R., Bartholy J. (2007): Detected trends in extreme temperature and precipitation indices in the Central/Eastern European region. 87th AMS Annual Meeting (AMS Forum: Climate Variations and Change Manifested by Changes in Weather). San Antonio, TX, 1418 January 2007.

[193] Pouget, R. (1963): Recherches physiologiques sur le repos végétatif de la vigne (Vitis vinifera L.): la dormance des bourgeons et le mécanisme de sa disparition. PhD Thesis Bordeaux University \& Ann Amelior Plantes 13 Special Issue.

[194] Pouget, R. (1968): Nouvelle conception du seuil de croissance chez la vigne. Vitis 7:201205.

[195] Pouget, R. (1988): Le débourrement des bourgeons de la vigne: méthode de prévision et principes d'établissement d'une échelle de précocité de débourrement. Conn Vigne-Vin 22(2):105-123.

[196] Prentice, I. C., Sykes, M. T., Cramer, W. (1991): The possible dynamic response of northern forests to global warming. Global Ecology and Biogeography Letters 1: 129 \pm 135 .

[197] Price, M. V., Waser, N. M. (1998): Effects of experimental warming on plant reproductive phenology in a subalpine meadow. Ecology 79:1261-1271. 
[198] Randerson, J.T., Field, c. B., Fung, I. Y, Tans, P. P. (1999): Increases in early season ecosystem uptake explain recent changes in the seasonal cycle of atmospheric $\mathrm{CO} 2$ at high northern latitudes. Geophys. Res. Lett. 26, 2765-2768.

[199] Réaumur, R. A. F. (1735): Observations du thermomètre, faites à Paris pendant l'année 1735, comparées avec celles qui ont été faites sous la ligne, à l'isle de France, à Alger et quelques unes de nos isles de l'Amérique. Académie des Sciences de Paris 545.

[200] Ribereau-Gayon, P., Guimberteau, G. (1996 a): Vintage Reports: 1988-1996, University of Bordeaux, Bordeaux, France.

[201] Ribéreau-Gayon, J., Peynaud, E., Ribéreau-Gayon, P. and Sudraud, P. (1975) : Traité d'oenologie Sciences et techniques du vin. Vol. 2. Ed. Dunod, Paris (1975).

[202] Ribéreau-Gayon, J., Peynaud, E., Ribéreau-Gayon, P. and Sudraud, P. (1976) Traité d'oenologie Sciences et techniques du vin. Vol. 3. Ed. Dunod, Paris (1976).

[203] Richard, P. (1985): Contribution aéropalynologique à l'étude de l'action des facteurs climatiques sur la floraison de l'Orme (Ulmus campestris) et de 1' If (Taxus baccata). Pollen and Spores 27, 53-94.

[204] Richardson, E. A., Seeley, S. D., Walker, D. R. (1974): A model for estimating the completation of rest for Redhaven and Elberta peach trees. HortScience 9(4):331-332

[205] Richardson, E. A., Seeley, S. D., Walker, R. D., Anderson, J., Ashcroft, G. (1975): Phenoclimatography of spring peach bud development. HortScience 10:236-237

[206] Riou, C. (1994): The effect of climate on grape ripening: application to the zoning of sugar content in the European community. CECACEE- CECA, Luxembourg.

[207] Rodriguez-Trellis, F., Rodriguez, M. A. (1998): Rapid micro-evolution and loss of chromosomal diversity in Drosophila in response to climate warming. Evol Ecol 12:829838 .

[208] Roeckner, E., Bäuml, G., Bonaventura, L., Brokopf, R., Esch, M., Giorgetta, M., Hagemann, S., Kirchner, I., Kornblueh, L., Manzini, E., Rhodin, A., Schlese, U. Schulzweida, U., Tompkins, A. (2003): The atmospheric general circulation model ECHAM5. Part I: Model description. Max Planck Institute for Meteorology Rep. 349, 127 pp.

[209] Rosenzweig, C., Casassa, G., Karoly, D. J., Imeson, A., Liu, C., Menzel, A., Rawlins, S., Root, T. L., Seguin, B., Tryjanowski, P. (2007): Assessment of observed changes and responses in natural and managed systems. Pages 79-131 in Parry, M. L., Canziani, O. F., Palutikof, J. P., van der Linden, P. J., Hanson, C. E., eds. Climate Change 2007: Impacts, Adaptation, and Vulnerability. Contribution of Working Group II to the Fourth Assessment Report of the Intergovernmental Panel on Climate Change. Cambridge University Press. 
[210] Root, T. L., Price, J. T., Hall, K. R., Schneider, S. H., Rosenzweig, C., Pounds, J. A. (2003): Fingerprints of global warming ont the wild animals and plants. Nature 421:57-60.

[211] Sabatelli, M. P., Stendardi, M. L. (1981): Influence of some meteorologic factors during the first months of the vegetative cycle on the sugar content in the berries of some grape cvs. Riv. Viticolt. Enol. (Conegliano), 34 271-276.

[212] Salinari, F., Giosuè, S., N, Tubiello, F., Rettori, A., Rossi, V., Spanna, F., Rosenzweig, C., Gullino, M. L. (2006): Downy mildew (Plasmopara viticola) epidemics on grapevine under climate change. Global Change Biology 12 (7), 1299-1307.

[213] Salinger, M. J., Sivakumar, M. V. K., Motha, R. (2005): Reducing vulnerability of agriculture and forestry to climate variability and change: Workshop summary and recommendations, Climatic Chane Volume 70, Issue 1-2, May 2005, Pages 341-362.

[214] Salma, I. (2006): A légköri aeroszol szerepe a globális éghajlatváltozásban. Magyar tudomány. MTA folyóirata. Budapest. 167 (2) 205-211.

[215] Salonius, P. (2002): A new climate index for grape growing in short season areas, Minnesota Grape Growers Association Annual Report, 2002.

[216] Sarvas R. (1974): Investigations on the annual cycle of development of forest trees. Autumn dormancy and winter dormancy. Communicationes Instituti Forestalis Fenniae 84, 101.

[217] Saure, M. (1985): Dormancy release in deciduous fruit trees. Hort Rev 7:239-300.

[218] Schemske, D. W. (1977): Flowering phenology and seed set in Claytonia virginica (Portulacaceae). Bull Torey Bot Club 104: 354-363.

[219] Schmitt, J. (1983): Density dependent pollinator foraging flowering phenology and temporal pollen dispersal patterns in Linanthus bicolor. Evolution 37:1247-1257.

[220] Schnelle, F., Volkert, E. (1974): International phenological observations. In Phenology and Seasonality Modelling (ed. H. Lieth), pp. 383-387. Springer Verlag, New York.

[221] Schwartz, M. D. (2003): Phenoclimatic measures. In Phenology: An Integrative Environmental Science (Schwartz, M.D., ed.), pp. 331- 343, Kluwer.

[222] Schwartz, P., Randall, D. (2003): An abrupt climate change scenario and its implications for United States National Security. http://www. grist. org/pdf/AbruptClimateChange2003.pdf

[223] Sefc, K., Steinkeller, H., Wagner, H. W., Gloessl, Regner, F. (1997): Application of microsatellit markers to parentage studies in grapevine. Vitis 36 (4), 179-183.

[224] Sellers, W. D. (1965): Physical climatology. University of Chicago Press, Chicago, IL.

[225] SEG, 2007, Confronting Climate Change: Avoiding the Unmanageable and Managing the Unavoidable, http://www.unfoundation.org/files/pdf/2007/SEG_Report.pdf 
[226] Sherry, R. A. et al. (2007): Divergence of reproductive phenology under climate warming. Proc. Natl. Acad. Sci. U. S. A. 104, 198-202.

[227] Singleton, V. L., Esau, P. (1969): Phenolic substances in grapes and wine, and their significance. Adv. Food Res. Supp. 1, 112-133.

[228] Smart, R. E., Dry, P. R. (1980): A climatic classification for Australian viticultural regions. The Australian Grapegrower and Winemaker 196: 8, $10 \& 16$.

[229] Sparks, T. H., Carey, P. D. (1995): The responses of species to climate over two centuries: an analysis of the Marsham phenological record, 1736-1947. J. Ecol. 83, 321-329.

[230] Sparks, T. H., Tryjanowski, P. (2005): The detection of climate impacts: some methodological considerations. Int. J. Climatol. 25, 271-277.

[231] Sparks, T. H., Menzel, A., Stenseth, N. C. (2009): European cooperation in plant phenology: Introduction. Climate Research 39: 175-177.

[232] Stafne, E. T., Ker, K. (2009): Grapevine Phenology and Data Collection. Oklahoma State University.

http://www.grapes.okstate.edu/PDFs/2009/GrapevinePhenologyandDataCollection2009.pdf

[233] Suthurst, R. W., Russell, B., Maywald, G. F. (2000): Predicting the effects of climate change on pests of grapes using the CLIMEX model. In: Proceedings of 5th International Symposium on Cool Climate Viticulture and Oenology, January, 2000, Melbourne, Australia.

[234] Szász, G., Tőkei, L. (1997): Meteorológia mezőgazdáknak, kertészeknek, erdészeknek. Mezőgazda Kiadó, Budapest. 209-219.

[235] Teszlák, P., Mika, J., Csikász-Krizsics, A., Werner, J., Forgács, B., Kozma, P. (2009): A klímaváltozás hatása a borszőlö biológiai jellemzőire, a termés mennyiségére és minőségére (review). Kertgazdaság, 2009/4.

[236] Tomana, T., Utsunomiya, N., Dataoka, I. (1979): The effect of environmental temperatures on fruit on ripening on the tree. II. The effect of temperatures around whole vines and clusters on the coloration of 'Kyoho'grapes. J. Jap. Soc. Hort. Sci. 48, 261-266.

[237] Tonietto, J., Carbonneau, A. (2004): A multicriteria climatic classification system for grape growing regions worldwide. Agricultural and Meteorology, 124: 81-97.

[238] Torma, Cs., Bartholy, J., Pongrácz, R., Barcza, Z., Coppola, E., Giorgi, F. (2008): Adaptation and validation of the RegCM3 climate model for the Carpathian Basin. Időjárás, 112(3-4.): 233-247.

[239] Torma, Cs., E. Coppola, F. Giorgi, J. Bartholy, R. Pongrácz, (2011): Validation of a high resolution version of the regional climate model RegCM3 over the Carpathian Basin. Journal of Hydrometeorology. 12. (No 1.), pp 84-100. 
[240] Walther, G. R., Post, E., Convey, P., Menzel, A., Parmesan, C., Beebee, T. J. C., Fromentin, J. M., Guldberg, O. H., Bairlein, F. (2002): Ecological responses to recent climate change. Nature 416: 389-395.

[241] Walther, G. R, Burga, C. A, Edwards, P. J. (eds). (2001): „Fingerprints” of climatic change-Adapted behaviour and shifting species Ranges. Kluwer Academic/Plenum, New York, pp 123-137.

[242] Webb, L. B., Whetton, P. H., Barlow, E. W. R. (2005): Impact on Australian Viticulture from Greenhouse Induced Temperature Change. International congress on modeling and decision making, 2005, Modelling and Stimulation Society of Australia and New Zealand, 2005: $1504 \sim 1510$.

[243] Weise, T. (2009): Global Optimization Algorithms - Theory and Application http://www.it-weise.de/projects/book.pdf.

[244] Winkler, A. J., Cook, J. A., Kliere, W. M., Lider, L. A. (1974): General Viticulture (2nd ed.). University of California Press. ISBN 0-520-02591-1.

[245] Wit, de C. T., van Keulen, H. (1972): Simulation of transport processes in Soils. Pudoc, Wageningen. $100 \mathrm{p}$.

[246] Wit, de C. T., Goudriaan, Y. (1974): Simulation of Ecological Processes. Pudos, Wageningen, $175 \mathrm{p}$.

[247] Wit, de. C. T. (1982): Simulation of living systems. In: Simulation of plant growth and crop production. ed. by F. W. T. Pening de Vries and H. H. Van Laar. pp. 3-8. Centre for Agric. Pub. and Doc. (PUDOC) Wageningen.

[248] Wolf, J., Semenov, M. A., Eckersten, H., Evans, L. G., Iglesias, A., Porter, J. R. (1995): Effects on winter wheat: A comparison of five models. In: Harrison P., Butterfield R. E., Downing T. E. (eds): Climate Change and Agriculture in Europe. Assessment of impacts and adaptation. Environmental Change Unit, University of Oxford. pp. 231-279.

[249] Wolf, T. K., Boyer, J. D. (2003): "Vineyard Site Selection," Virginia Cooperative Extension Publication Number 463-020. http://www.ext.vt.edu/pubs/viticulture/463-020/463$\underline{020 . h t m l}$

[250] Wood, R. A., Vellinga, M., Thorpe, R. (2003): Global Warming and THC stability. Philosophical Transactions of the Royal Society A. 361,1961-1976.

[251] Wookey, P. A., Parsons, A. N., Welker, J. M., Potter, J. A., Callaghan, T. V., Lee, J. A., Press, M. C. (1993): Comparative responses in phenology and reproductive development to simulated environmental change in sub-arctic and high arctic plants. Oikos 67:490-502. 
[252] World Meteorological Organization (2009): Strategic Plan for the Implementation of WMO's World Weather Research Programme (WWRP): 2009-2017. http://www.wmo.int/pages/prog/arep/wwrp/new/documents/final_wwrp_sp_6_oct.pdf

[253] Wuethrich, B. (2000): How climate change alters rhytms of the wild? Science 287:793795.

[254] Zanathy, G. (2008): Gondolatok a klímaváltozás szőlőtermesztésre gyakorolt hatásáról. Agro Napló 2008/2.

[255] Zhou, L., Tucker, C. J., Kaufmann, R. K., Slayback, D., Shabanov, N. V., Myneni, R. B. (2001): Variations in northern vegetation activity inferred from satellite data of vegetation index during 1981 to 1999. J. Geophys. Res. Atmos. 106, 20069-20083.

[256] Zorer, R. (2008): Impacts of Climate Variability and Change on Wine Grape Quality. Klímaváltozás hatása a szőlő- és bortermelésre Konferencia. 2008. november 24-25. Budapest.

[257] Zsolnai B. 2006. Egy új szőlőkártevő jelent meg Magyarországon. www.agraroldal.hu/uj$\underline{\text { szolokartevo-jelent-meg-magyarorszagon_elorejelzes.html }}$ 


\section{RÖVIDÍTÉSEK JEGYZÉKE}

A1

A1B

A1FI

A1T

A2

ACIA

ANOVA

AR

AR4

B1

B2

$\mathrm{BBCH}$

BEDD

BPR

$\mathrm{Ch}$

$\mathrm{CH}$

Ch 75

Ch_96

$\mathrm{CNI}$

$\mathrm{CO}$

DR

$\mathrm{D}_{\text {start }}$

$D_{i j \text {, mod }}^{r f}$

$D_{i j, m f}^{r f}$

EHM

EL00

ENSZ

ET

F

FAR

GDD

GDD $_{\text {krit }}$

GDH

GSATG

GSATN

GSATX

GSR

GSRD

HHM

$\mathrm{HI}$

Hl_K9

Hl_P41

HMX

IPCC

MADR

MHDR

MJaT

MJuT

NEHD
Globális gazdasági szcenárió

kiegyensúlyozott szecnárió

fosszilis intenzív szecnárió

nem fosszilis energiaforrások használatú szecnárió

gazdasági regionális szcenárió

Arctic Climate Impact Assessment

Analysis of Variance

Annual Rainfall

Fourth Assessment Report

Globális környezeti szcenárió

Regionális környezeti szcenárió

Lorenz féle szőlő fenológiai skála

Biolodically Effective Day Degrees

Bloom Period Precipitation

Chardonnay fajta

mélynyugalmi hatás (chilling effect)

Chardonnay 75 klón

Chardonnay 96 klón

Cool Night Index

Continentality

Diurnal Range

kezdönap

a modell által becsült rügyfakadási időpont (nap)

megfigyelt rügyfakadási időpont (nap)

Egyszerü Höösszeg Modell

Eichorn-Lorenz féle szőlő fenológiai skála

Egyesült Nemzetek Szervezete

Sum of Daily Temperature Excursion

kényszernyugalmi hatás (forcing effect)

First Assessment Report

Growing Degree Days

fajtánkénti kritikus höösszeg $\left({ }^{\circ} \mathrm{C}\right)$

Growing Degree Hours

Growing Season Average Temperature

Growing Season Average Minimum Temperature

Growing Season Average Maximum Temperature

Growing Season Rainfall

Number of Growing Season Rain Days

Hideghatás Modell

Huglin Index

Hárslevelü K9 klón

Hárslevelü P41 klón

Harvest Maximum Temperature

Intergovernmental Panel on Climate Change

Mean April Daily Range

Mean Harvest Daily Range

Mean January Temperature

Mean July Temperature

Number of Extremly Hot Days 


$\begin{array}{ll}\text { NFD } & \text { Number of Frost Days } \\ \text { NFFD } & \text { Number of Fall Frost Days } \\ \text { NHD } & \text { Number of Hot Days } \\ \text { NID } & \text { Number of Icy Days } \\ \text { NOAA } & \text { National Oceanic and Atmospheric Administration } \\ \text { NPP } & \text { Net Primary Product } \\ \text { NSD } & \text { Number of Summer Days } \\ \text { NSFD } & \text { Number of Spring Frost Days } \\ \text { OMSz } & \text { Országosz Meteorológiai Szervezet } \\ \text { Pb_54 } & \text { Pinot blanc 54 klón } \\ \text { Pb_55 } & \text { Pinot blanc 55 klón } \\ \text { Pb_D55 } & \text { Pinot blanc D55 klón } \\ \text { RAT } & \text { Ripening Average Temperature } \\ \text { RegCM } & \text { Regionális klímamodell } \\ \text { RGP } & \text { Ribérau-Gayon-Peynaud Index } \\ \text { RMSE } & \text { Root Mean Square Error } \\ \text { RPR } & \text { Ripening Period Precipitation } \\ \text { Rr_239 } & \text { Rajnai rizling 239 klón } \\ \text { Rr_378 } & \text { Rajnai rizling 378 klón } \\ \text { Rr_391 } & \text { Rajnai rizling 391 klón } \\ \text { Rr_49 } & \text { Rajnai rizling 49 klón } \\ \text { SAR } & \text { Second Assessment Report } \\ \text { SFI } & \text { Spring Frost Index by Gladstones } \\ \text { SFI } & \text { Spring Frost Index by Wolf-Boyer } \\ \text { SR } & \text { Summer Rainfall } \\ \text { SRES } & \text { Special Report on Emissions Scenarios } \\ \text { Szb } & \text { Szürkebarát fajta } \\ \text { Szb_34 } & \text { Szürkebarát 34 klón } \\ \text { Szb_52 } & \text { Szürkebarát 52 klón } \\ \text { TAR } & \text { Third Assessment Report } \\ T_{\text {bázis }} & \text { bázis hömérséklet } \\ \mathrm{T}_{\mathrm{k} \text { _átl }} & \left.\text { napi középhömérséklet ( }{ }^{\circ} \mathrm{C}\right) \\ \text { WCRP } & \text { World Climate Research Programme } \\ \text { WI } & \text { Winkler Index } \\ \text { WMN } & \text { Winter Minimum Temperature } \\ \text { WMO } & \text { World Meteorological Organization } \\ \text { WR } & \text { Winter Rainfl }\end{array}$


1. Melléklet: A Huglin- és Winkler-indexek, a biológiailag hatásos hőösszegek (BEDD), a júliusi és januári átlaghőmérsékletek (MJuT, MJaT), valamint a tenyészidőszakok átlaghőmérséklete (GSAT), átlagos maximum és minimum hőmérséklete (GSATX, GSATN) $\left[{ }^{\circ} \mathrm{C}\right] 1977$ és 2003 között

$\begin{array}{crrrrrrrr}\text { Év } & \text { Huglin } & \text { Winkler } & \text { BEDD } & \text { MJuT } & \text { MJaT } & \text { GSAT } & \text { GSATX } & \text { GSATN } \\ 1977 & 1918 & 1490 & 1208 & 21 & 0 & 17 & 22 & 10 \\ 1978 & 1691 & 1270 & 1124 & 20 & 0 & 16 & 20 & 10 \\ 1979 & 2035 & 1567 & 1265 & 20 & -3 & 17 & 22 & 10 \\ 1980 & 1707 & 1304 & 1137 & 20 & -4 & 16 & 20 & 10 \\ 1981 & 2045 & 1595 & 1298 & 21 & -3 & 17 & 22 & 11 \\ 1982 & 2158 & 1736 & 1373 & 22 & -4 & 18 & 22 & 11 \\ 1983 & 2297 & 1799 & 1373 & 24 & 3 & 18 & 23 & 11 \\ 1984 & 1936 & 1518 & 1288 & 21 & 0 & 17 & 22 & 10 \\ 1985 & 2053 & 1589 & 1281 & 23 & -6 & 17 & 22 & 10 \\ 1986 & 2344 & 1777 & 1399 & 22 & 0 & 18 & 24 & 11 \\ 1987 & 2111 & 1614 & 1307 & 24 & -5 & 17 & 23 & 11 \\ 1988 & 2259 & 1651 & 1288 & 24 & 2 & 17 & 24 & 10 \\ 1989 & 2175 & 1596 & 1320 & 23 & -1 & 17 & 23 & 11 \\ 1990 & 2196 & 1607 & 1282 & 22 & 0 & 17 & 24 & 9 \\ 1991 & 2124 & 1550 & 1246 & 24 & 0 & 17 & 23 & 10 \\ 1992 & 2535 & 1906 & 1389 & 24 & 0 & 19 & 24 & 10 \\ 1994 & 2545 & 2026 & 1377 & 26 & 3 & 19 & 24 & 11 \\ 1995 & 2258 & 1847 & 1392 & 26 & 0 & 18 & 24 & 10 \\ 1996 & 2085 & 1691 & 1368 & 21 & -2 & 18 & 22 & 10 \\ 1997 & 2200 & 1750 & 1315 & 22 & -3 & 17 & 22 & 9 \\ 1998 & 2279 & 1831 & 1352 & 24 & 4 & 19 & 23 & 11 \\ 1999 & 2337 & 1895 & 1458 & 24 & 0 & 19 & 23 & 11 \\ 2000 & 2558 & 2157 & 1594 & 22 & -1 & 20 & 25 & 12 \\ 2001 & 2232 & 1883 & 1452 & 23 & 1 & 19 & 23 & 11 \\ 2002 & 2439 & 1957 & 1404 & 25 & 1 & 19 & 24 & 12 \\ 2003 & 2512 & 1833 & 1373 & 22 & -3 & 18 & 24 & 11\end{array}$


2. Melléklet: A szüretidő maximum hőmérséklete (HMX), a téli minimum hőmérséklet (WMN), az érésidő átlagos hőmérséklete (RAT), hideg éjszaka-index (CNI) és a kontinentális $(\mathrm{CO})$ hatás értékei [ $\left.{ }^{\circ} \mathrm{C}\right] 1977$ és 2003 között

$\begin{array}{cccccc}\text { Év } & \text { HMX } & \text { WMN } & \text { RAT } & \text { CNI } & \text { CO } \\ 1977 & 24 & -20 & 16 & 8 & 21 \\ 1978 & 23 & -17 & 15 & 10 & 20 \\ 1979 & 25 & -16 & 16 & 10 & 23 \\ 1980 & 24 & -17 & 16 & 9 & 24 \\ 1981 & 25 & -18 & 17 & 12 & 24 \\ 1982 & 26 & -21 & 18 & 13 & 27 \\ 1983 & 26 & -15 & 17 & 11 & 21 \\ 1984 & 25 & -13 & 17 & 11 & 21 \\ 1985 & 25 & -22 & 18 & 10 & 29 \\ 1986 & 26 & -18 & 17 & 9 & 21 \\ 1987 & 26 & -27 & 18 & 12 & 29 \\ 1988 & 27 & -11 & 17 & 11 & 22 \\ 1989 & 26 & -12 & 16 & 11 & 24 \\ 1990 & 26 & -14 & 17 & 9 & 22 \\ 1991 & 27 & -18 & 17 & 10 & 24 \\ 1992 & 29 & -13 & 18 & 8 & 24 \\ 1994 & 29 & -15 & 19 & 13 & 23 \\ 1995 & 27 & -13 & 18 & 10 & 27 \\ 1996 & 24 & -19 & 16 & 8 & 23 \\ 1997 & 27 & -20 & 19 & 8 & 25 \\ 1998 & 27 & -15 & 17 & 10 & 20 \\ 1999 & 27 & -18 & 19 & 13 & 24 \\ 2000 & 27 & -14 & 20 & 10 & 24 \\ 2001 & 25 & -13 & 19 & 10 & 22 \\ 2002 & 27 & -18 & 18 & 10 & 25 \\ 2003 & 28 & -22 & 17 & 10 & 25\end{array}$


3. Melléklet: Az extrém meleg napok száma (NEHD), a meleg napok száma (NHD), a nyári napok száma (NSD), a fagyos napok száma (NFD), a jeges napok száma (NID), a szőlő fagyindex (F8D), a szölö súlyos fagyindex(FS15D), valamint a tavaszi (NSFD) és őszi (NFFD) fagyos napok száma 1977 és 2003 között

$\begin{array}{rrrrrrrrrr}\text { Ev } & \text { NEHD } & \text { NHD } & \text { NSD } & \text { NFD } & \text { NID } & \text { F15D } & \text { F8D } & \text { NSFD } & \text { NFFD } \\ 1977 & 0 & 10 & 82 & 41 & 4 & 1 & 7 & 8 & 11 \\ 1978 & 0 & 2 & 46 & 56 & 8 & 1 & 7 & 12 & 16 \\ 1979 & 0 & 18 & 78 & 57 & 9 & 2 & 12 & 8 & 14 \\ 1980 & 0 & 7 & 43 & 70 & 8 & 2 & 14 & 17 & 14 \\ 1981 & 1 & 17 & 64 & 53 & 10 & 1 & 20 & 7 & 13 \\ 1982 & 0 & 18 & 87 & 64 & 11 & 6 & 21 & 14 & 8 \\ 1983 & 0 & 27 & 88 & 49 & 1 & 0 & 3 & 9 & 25 \\ 1984 & 2 & 14 & 59 & 64 & 0 & 0 & 4 & 20 & 8 \\ 1985 & 1 & 20 & 75 & 71 & 34 & 18 & 37 & 13 & 13 \\ 1986 & 0 & 31 & 96 & 74 & 11 & 4 & 15 & 16 & 20 \\ 1987 & 2 & 22 & 77 & 68 & 18 & 9 & 33 & 19 & 10 \\ 1988 & 9 & 34 & 95 & 55 & 1 & 0 & 1 & 19 & 33 \\ 1989 & 1 & 26 & 78 & 46 & 4 & 0 & 4 & 2 & 18 \\ 1990 & 7 & 35 & 89 & 55 & 4 & 0 & 4 & 8 & 14 \\ 1991 & 4 & 29 & 89 & 63 & 18 & 6 & 19 & 9 & 15 \\ 1992 & 15 & 53 & 106 & 67 & 3 & 0 & 4 & 19 & 9 \\ 1994 & 14 & 61 & 107 & 50 & 4 & 0 & 8 & 14 & 15 \\ 1995 & 7 & 42 & 95 & 56 & 4 & 0 & 6 & 15 & 23 \\ 1996 & 0 & 20 & 68 & 82 & 12 & 2 & 20 & 26 & 12 \\ 1997 & 1 & 36 & 94 & 96 & 7 & 0 & 18 & 29 & 25 \\ 1998 & 14 & 46 & 77 & 61 & 7 & 1 & 11 & 25 & 18 \\ 1999 & 3 & 22 & 100 & 72 & 4 & 0 & 6 & 15 & 19 \\ 2000 & 10 & 46 & 111 & 66 & 2 & 0 & 4 & 13 & 8 \\ 2001 & 4 & 31 & 85 & 47 & 1 & 0 & 6 & 8 & 22 \\ 2002 & 5 & 35 & 103 & 48 & 2 & 1 & 6 & 15 & 3 \\ 2003 & 4 & 56 & 120 & 89 & 26 & 10 & 31 & 25 & 14\end{array}$


4. Melléklet: A Gladstones (SFIGlad) és a Wolf-Boyer féle (SFIWB) tavaszi fagyindex, a júliusi hőmérsékleti terjedelem (DR), az áprilisi átlagos napi hőingás (MADR), és a szüreti átlagos napi hőingás (MHDR), az érésidő napi höingás összege (ET) és a Riberau-Gayon-Peynaud index (RGP) értékei [ $\left.{ }^{\circ} \mathrm{C}\right] 1977$ és 2003 között

$\begin{array}{cccccccc}\text { Év } & \text { SFI_Glad } & \text { SFI_WB } & \text { DR } & \text { MADR } & \text { MHDR } & \text { ET } & \text { RGP } \\ 1977 & 11 & 5 & 21 & 10 & 11 & 1800 & 1912 \\ 1978 & 10 & 5 & 21 & 11 & 11 & 1706 & 1443 \\ 1979 & 9 & 5 & 21 & 11 & 13 & 1796 & 1907 \\ 1980 & 9 & 4 & 22 & 9 & 11 & 1618 & 1426 \\ 1981 & 12 & 6 & 22 & 12 & 11 & 1712 & 1903 \\ 1982 & 10 & 5 & 24 & 10 & 11 & 1719 & 2076 \\ 1983 & 13 & 5 & 22 & 11 & 12 & 1843 & 2190 \\ 1984 & 13 & 6 & 26 & 11 & 11 & 1773 & 1820 \\ 1985 & 11 & 5 & 25 & 11 & 13 & 1857 & 1900 \\ 1986 & 15 & 7 & 23 & 13 & 15 & 2058 & 2308 \\ 1987 & 10 & 6 & 26 & 11 & 13 & 1837 & 1918 \\ 1988 & 12 & 6 & 30 & 12 & 12 & 2082 & 2141 \\ 1989 & 13 & 7 & 25 & 13 & 12 & 1954 & 1996 \\ 1990 & 11 & 5 & 31 & 11 & 14 & 2233 & 2093 \\ 1991 & 12 & 6 & 24 & 13 & 13 & 1967 & 1864 \\ 1992 & 14 & 7 & 26 & 13 & 16 & 2167 & 2272 \\ 1994 & 13 & 6 & 23 & 12 & 13 & 2103 & 2390 \\ 1995 & 17 & 6 & 27 & 12 & 13 & 2183 & 2034 \\ 1996 & 13 & 6 & 28 & 13 & 11 & 1815 & 1847 \\ 1997 & 14 & 5 & 23 & 11 & 15 & 2166 & 2088 \\ 1998 & 13 & 6 & 29 & 11 & 10 & 1937 & 1979 \\ 1999 & 13 & 6 & 25 & 12 & 12 & 1877 & 2054 \\ 2000 & 17 & 7 & 26 & 13 & 13 & 2060 & 2604 \\ 2001 & 12 & 6 & 25 & 12 & 12 & 1750 & 2078 \\ 2002 & 19 & 6 & 29 & 12 & 12 & 1841 & 2294 \\ 2003 & 15 & 7 & 25 & 13 & 13 & 2038 & 2293\end{array}$


5. Melléklet: Csapadékindexek [mm]: éves (AR), nyári (SR), téli (WR) csapadékmennyiségek, a tenyészidőszak (GSR), a virágzás (BPR), az érési időszak (RPR) csapadékmennyisége, valamint a tenyészidőszak csapadékos napjainak száma (GSRD [nap]).

$\begin{array}{cccccccc}\text { Év } & \text { AR } & \text { SR } & \text { WR } & \text { GSR } & \text { BPR } & \text { RPR } & \text { GSRD } \\ 1977 & 367 & 71 & 237 & 169 & 2 & 49 & 50 \\ 1978 & 472 & 182 & 113 & 388 & 63 & 51 & 67 \\ 1979 & 457 & 110 & 148 & 250 & 66 & 32 & 54 \\ 1980 & 609 & 126 & 180 & 408 & 62 & 125 & 76 \\ 1981 & 454 & 117 & 167 & 307 & 59 & 84 & 65 \\ 1982 & 360 & 131 & 184 & 229 & 42 & 39 & 56 \\ 1983 & 348 & 67 & 126 & 240 & 45 & 96 & 52 \\ 1984 & 421 & 44 & 95 & 289 & 66 & 88 & 68 \\ 1985 & 521 & 92 & 157 & 311 & 106 & 64 & 62 \\ 1986 & 335 & 69 & 240 & 182 & 59 & 24 & 49 \\ 1987 & 551 & 96 & 144 & 364 & 90 & 42 & 63 \\ 1988 & 461 & 83 & 213 & 268 & 62 & 94 & 56 \\ 1989 & 483 & 86 & 126 & 357 & 66 & 109 & 77 \\ 1990 & 413 & 80 & 101 & 276 & 24 & 67 & 56 \\ 1991 & 515 & 117 & 156 & 403 & 74 & 62 & 71 \\ 1992 & 469 & 169 & 77 & 344 & 156 & 49 & 53 \\ 1994 & 378 & 57 & 158 & 269 & 29 & 77 & 58 \\ 1995 & 698 & 141 & 153 & 465 & 159 & 184 & 55 \\ 1996 & 550 & 117 & 201 & 400 & 28 & 142 & 70 \\ 1997 & 393 & 138 & 119 & 256 & 91 & 47 & 54 \\ 1998 & 605 & 111 & 155 & 455 & 53 & 143 & 77 \\ 1999 & 732 & 186 & 183 & 440 & 66 & 64 & 68 \\ 2000 & 360 & 47 & 269 & 209 & 12 & 50 & 36 \\ 2001 & 576 & 186 & 199 & 390 & 35 & 125 & 51 \\ 2002 & 383 & 86 & 101 & 273 & 39 & 82 & 63 \\ 2003 & 412 & 101 & 148 & 291 & 26 & 75 & 49\end{array}$


6. Melléklet: Becsült Huglin- és Winkler-indexek, biológiailag hatásos hőösszegek, júliusi és januári átlaghőmérsékletek, valamint a tenyészidőszakok átlaghőmérséklete, átlagos maximum és minimum hömérséklete $\left[{ }^{\circ} \mathrm{C}\right] 1961$ és 1990 között

$\begin{array}{ccccccccc}\text { Ev } & \text { Huglin } & \text { Winkler } & \text { BEDD } & \text { MJuT } & \text { MJaT } & \text { GSAT } & \text { GSATX } & \text { GSATN } \\ 1961 & 1868 & 1292 & 1111 & 23 & 0 & 15 & 21 & 10 \\ 1962 & 1821 & 1256 & 1098 & 21 & -1 & 15 & 21 & 10 \\ 1963 & 1836 & 1269 & 1064 & 22 & 2 & 15 & 20 & 10 \\ 1964 & 1948 & 1400 & 1226 & 20 & 5 & 16 & 22 & 12 \\ 1965 & 2284 & 1608 & 1238 & 24 & 1 & 17 & 23 & 11 \\ 1966 & 1762 & 1203 & 987 & 20 & 3 & 15 & 21 & 10 \\ 1967 & 1793 & 1322 & 1190 & 20 & 1 & 16 & 21 & 11 \\ 1968 & 2030 & 1399 & 1068 & 23 & 3 & 16 & 22 & 10 \\ 1969 & 1765 & 1224 & 1097 & 20 & 2 & 15 & 21 & 11 \\ 1970 & 1575 & 1021 & 931 & 18 & 0 & 14 & 20 & 10 \\ 1971 & 1461 & 1000 & 957 & 18 & -6 & 14 & 19 & 10 \\ 1972 & 1656 & 1122 & 978 & 19 & -4 & 15 & 20 & 10 \\ 1973 & 1753 & 1215 & 1064 & 19 & 4 & 15 & 21 & 11 \\ 1974 & 1903 & 1272 & 1123 & 20 & 0 & 16 & 22 & 11 \\ 1975 & 1795 & 1267 & 1102 & 20 & 1 & 16 & 21 & 11 \\ 1976 & 2162 & 1563 & 1270 & 23 & 4 & 17 & 23 & 12 \\ 1977 & 1627 & 1110 & 965 & 20 & 2 & 14 & 19 & 10 \\ 1978 & 1683 & 1182 & 1002 & 19 & 2 & 15 & 21 & 11 \\ 1979 & 1881 & 1293 & 1141 & 20 & 1 & 15 & 21 & 11 \\ 1980 & 1998 & 1354 & 1137 & 20 & 3 & 16 & 22 & 10 \\ 1981 & 1748 & 1177 & 1068 & 20 & 2 & 15 & 20 & 10 \\ 1982 & 1574 & 1099 & 955 & 20 & 1 & 14 & 19 & 10 \\ 1983 & 1896 & 1332 & 1150 & 21 & 5 & 16 & 21 & 11 \\ 1984 & 1798 & 1215 & 1031 & 20 & 3 & 15 & 21 & 10 \\ 1985 & 1764 & 1167 & 989 & 18 & 0 & 15 & 21 & 10 \\ 1986 & 1951 & 1455 & 1181 & 23 & 4 & 16 & 22 & 12 \\ 1987 & 1740 & 1190 & 1033 & 18 & 1 & 15 & 21 & 10 \\ 1988 & 1584 & 1052 & 900 & 20 & 2 & 14 & 20 & 9 \\ 1989 & 1904 & 1282 & 1032 & 21 & 2 & 16 & 21 & 10 \\ 1990 & 1892 & 1307 & 1084 & 21 & 2 & 15 & 21 & 10\end{array}$


7. Melléklet: A szüreti időszak maximum hömérséklete (HMX), a téli minimum hőmérséklet (WMN), az érésidő átlagos hőmérséklete (RAT), hideg éjszaka-index (CNI) és a kontinentális (CO) hatás értékei [ $\left.{ }^{\circ} \mathrm{C}\right] 1961$ és 1990 között

$\begin{array}{cccccc}\text { Ev } & \text { HMX } & \text { WMN } & \text { RAT } & \text { CNI } & \text { CO } \\ 1961 & 24 & -9 & 15 & 11 & 22 \\ 1962 & 25 & -18 & 15 & 10 & 22 \\ 1963 & 25 & -14 & 15 & 12 & 20 \\ 1964 & 24 & -7 & 15 & 12 & 16 \\ 1965 & 27 & -11 & 15 & 12 & 23 \\ 1966 & 24 & -10 & 13 & 8 & 17 \\ 1967 & 24 & -12 & 16 & 11 & 19 \\ 1968 & 27 & -13 & 16 & 12 & 19 \\ 1969 & 23 & -10 & 15 & 12 & 18 \\ 1970 & 22 & -13 & 13 & 11 & 18 \\ 1971 & 22 & -19 & 14 & 9 & 24 \\ 1972 & 23 & -19 & 14 & 11 & 23 \\ 1973 & 24 & -4 & 15 & 12 & 16 \\ 1974 & 25 & -10 & 16 & 11 & 20 \\ 1975 & 24 & -9 & 16 & 9 & 19 \\ 1976 & 26 & -13 & 16 & 10 & 19 \\ 1977 & 24 & -10 & 14 & 11 & 17 \\ 1978 & 24 & -9 & 13 & 9 & 17 \\ 1979 & 24 & -10 & 15 & 11 & 20 \\ 1980 & 26 & -13 & 16 & 10 & 16 \\ 1981 & 23 & -12 & 13 & 9 & 18 \\ 1982 & 23 & -10 & 14 & 10 & 19 \\ 1983 & 25 & -4 & 15 & 11 & 17 \\ 1984 & 24 & -15 & 16 & 12 & 17 \\ 1985 & 23 & -12 & 12 & 7 & 19 \\ 1986 & 26 & -9 & 17 & 12 & 19 \\ 1987 & 24 & -14 & 16 & 12 & 18 \\ 1988 & 23 & -11 & 13 & 10 & 18 \\ 1989 & 25 & -14 & 13 & 9 & 20 \\ 1990 & 26 & -10 & 16 & 11 & 19\end{array}$


8. Melléklet: Az extrém meleg napok száma (NEHD), a meleg napok száma (NHD), a nyári napok száma (NSD), a fagyos napok száma (NFD), a jeges napok száma (NID), valamint a tavaszi (NSFD) és őszi (NFFD) fagyos napok száma 1961 és 1990 között

$\begin{array}{cccccccccc}\text { Ev } & \text { NEHD } & \text { NHD } & \text { NSD } & \text { NFD } & \text { NID } & \text { F15D } & \text { F8D } & \text { NSFD } & \text { NFFD } \\ 1961 & 1 & 20 & 62 & 41 & 0 & 0 & 1 & 7 & 8 \\ 1962 & 3 & 19 & 63 & 41 & 10 & 1 & 10 & 9 & 9 \\ 1963 & 1 & 19 & 66 & 53 & 0 & 0 & 0 & 19 & 7 \\ 1964 & 0 & 18 & 55 & 35 & 0 & 0 & 0 & 4 & 0 \\ 1965 & 16 & 44 & 89 & 50 & 2 & 0 & 3 & 18 & 12 \\ 1966 & 3 & 26 & 65 & 45 & 1 & 0 & 5 & 7 & 7 \\ 1967 & 0 & 17 & 53 & 47 & 4 & 0 & 8 & 10 & 13 \\ 1968 & 11 & 39 & 80 & 41 & 2 & 0 & 2 & 9 & 7 \\ 1969 & 1 & 9 & 55 & 31 & 0 & 0 & 2 & 8 & 15 \\ 1970 & 0 & 14 & 39 & 51 & 4 & 0 & 6 & 11 & 19 \\ 1971 & 0 & 2 & 25 & 74 & 19 & 5 & 21 & 23 & 7 \\ 1972 & 2 & 16 & 52 & 63 & 18 & 6 & 22 & 16 & 8 \\ 1973 & 0 & 17 & 58 & 33 & 0 & 0 & 0 & 14 & 0 \\ 1974 & 0 & 20 & 66 & 37 & 0 & 0 & 0 & 6 & 7 \\ 1975 & 2 & 19 & 54 & 35 & 0 & 0 & 0 & 9 & 3 \\ 1976 & 10 & 33 & 84 & 38 & 2 & 0 & 2 & 9 & 4 \\ 1977 & 0 & 18 & 44 & 70 & 0 & 0 & 1 & 25 & 3 \\ 1978 & 4 & 22 & 44 & 42 & 0 & 0 & 0 & 7 & 5 \\ 1979 & 2 & 13 & 59 & 48 & 0 & 0 & 2 & 11 & 9 \\ 1980 & 1 & 29 & 66 & 41 & 0 & 0 & 1 & 7 & 26 \\ 1981 & 2 & 8 & 58 & 57 & 5 & 0 & 9 & 15 & 2 \\ 1982 & 0 & 12 & 51 & 64 & 0 & 0 & 3 & 21 & 9 \\ 1983 & 1 & 20 & 59 & 24 & 0 & 0 & 0 & 8 & 13 \\ 1984 & 0 & 22 & 66 & 37 & 3 & 0 & 3 & 13 & 8 \\ 1985 & 8 & 20 & 50 & 61 & 2 & 0 & 5 & 16 & 5 \\ 1986 & 6 & 33 & 74 & 46 & 0 & 0 & 1 & 16 & 9 \\ 1987 & 1 & 17 & 56 & 55 & 5 & 0 & 6 & 10 & 10 \\ 1988 & 3 & 17 & 51 & 61 & 3 & 0 & 7 & 32 & 22 \\ 1989 & 7 & 31 & 67 & 46 & 3 & 0 & 7 & 4 & 5 \\ 1990 & 2 & 30 & 66 & 50 & 0 & 0 & 5 & 17 & 3\end{array}$


9. Melléklet: A Gladstones (SFIGlad) és a Wolf-Boyer féle (SFIWB) tavaszi fagyindex, a júliusi hőmérsékleti terjedelem (DR), az áprilisi átlagos napi hőingás (MADR), és a szüreti átlagos napi hőingás (MHDR), érésidei napi hőingás összege (ET) és a Riberau-Gayon-Peynaud index (RGP) értékei $\left[{ }^{\circ} \mathrm{C}\right] 1961$ és 1990 között

$\begin{array}{cccccccc}\text { Ev } & \text { SFI_Glad } & \text { SFI_WB } & \text { DR } & \text { MADR } & \text { MHDR } & \text { ET } & \text { RGP } \\ 1961 & 12 & 4 & 26 & 9 & 9 & 1525 & 1590 \\ 1962 & 10 & 5 & 25 & 10 & 10 & 1588 & 1620 \\ 1963 & 11 & 4 & 23 & 8 & 10 & 1590 & 1486 \\ 1964 & 12 & 5 & 22 & 9 & 9 & 1434 & 1610 \\ 1965 & 14 & 6 & 30 & 11 & 10 & 1771 & 2114 \\ 1966 & 11 & 4 & 24 & 7 & 10 & 1623 & 1456 \\ 1967 & 13 & 5 & 22 & 10 & 10 & 1536 & 1598 \\ 1968 & 10 & 4 & 27 & 9 & 12 & 1867 & 1883 \\ 1969 & 11 & 4 & 24 & 9 & 10 & 1506 & 1481 \\ 1970 & 11 & 5 & 24 & 9 & 9 & 1537 & 1220 \\ 1971 & 10 & 4 & 22 & 7 & 9 & 1420 & 1046 \\ 1972 & 9 & 4 & 29 & 8 & 9 & 1497 & 1447 \\ 1973 & 11 & 4 & 25 & 9 & 9 & 1555 & 1368 \\ 1974 & 13 & 5 & 24 & 10 & 12 & 1680 & 1670 \\ 1975 & 12 & 5 & 25 & 10 & 10 & 1619 & 1627 \\ 1976 & 13 & 5 & 27 & 10 & 11 & 1732 & 2037 \\ 1977 & 10 & 4 & 24 & 9 & 9 & 1513 & 1303 \\ 1978 & 9 & 4 & 26 & 9 & 9 & 1572 & 1313 \\ 1979 & 11 & 5 & 28 & 9 & 10 & 1530 & 1593 \\ 1980 & 11 & 5 & 23 & 10 & 12 & 1773 & 1791 \\ 1981 & 14 & 5 & 26 & 10 & 9 & 1465 & 1388 \\ 1982 & 10 & 4 & 24 & 8 & 8 & 1411 & 1216 \\ 1983 & 9 & 4 & 24 & 9 & 10 & 1575 & 1584 \\ 1984 & 11 & 6 & 24 & 11 & 10 & 1599 & 1444 \\ 1985 & 13 & 5 & 27 & 11 & 10 & 1636 & 1541 \\ 1986 & 14 & 4 & 27 & 9 & 11 & 1649 & 1827 \\ 1987 & 10 & 5 & 24 & 10 & 10 & 1635 & 1553 \\ 1988 & 11 & 4 & 28 & 9 & 9 & 1652 & 1305 \\ 1989 & 13 & 5 & 26 & 10 & 10 & 1710 & 1666 \\ 1990 & 10 & 4 & 27 & 8 & 12 & 1854 & 1680\end{array}$


10. Melléklet: Csapadékindexek [mm]: éves (AR), nyári (SR), téli (WR) csapadékmennyiségek, a tenyészidőszak (GSR), a virágzás (BPR), az érési időszak (RPR) csapadékmennyisége, valamint a tenyészidőszak csapadékos napjainak száma (GSRD) 1961 és 1990 között

$\begin{array}{cccccccc}\text { Ev } & \text { AR } & \text { SR } & \text { WR } & \text { GSR } & \text { BPR } & \text { RPR } & \text { GSRD } \\ 1961 & 565 & 91 & 92 & 314 & 82 & 88 & 89 \\ 1962 & 609 & 116 & 308 & 289 & 38 & 76 & 103 \\ 1963 & 720 & 124 & 342 & 393 & 30 & 151 & 92 \\ 1964 & 649 & 150 & 317 & 413 & 58 & 131 & 107 \\ 1965 & 498 & 61 & 158 & 220 & 34 & 117 & 64 \\ 1966 & 628 & 111 & 341 & 381 & 46 & 125 & 101 \\ 1967 & 763 & 153 & 302 & 387 & 88 & 118 & 96 \\ 1968 & 425 & 29 & 355 & 177 & 16 & 26 & 75 \\ 1969 & 683 & 80 & 271 & 367 & 29 & 54 & 87 \\ 1970 & 773 & 94 & 245 & 414 & 55 & 130 & 101 \\ 1971 & 734 & 118 & 331 & 496 & 51 & 117 & 119 \\ 1972 & 543 & 82 & 214 & 252 & 39 & 70 & 98 \\ 1973 & 668 & 150 & 262 & 497 & 69 & 121 & 109 \\ 1974 & 577 & 82 & 271 & 293 & 64 & 77 & 77 \\ 1975 & 568 & 135 & 255 & 308 & 54 & 95 & 87 \\ 1976 & 523 & 79 & 229 & 253 & 52 & 53 & 76 \\ 1977 & 648 & 80 & 253 & 383 & 34 & 112 & 98 \\ 1978 & 782 & 115 & 272 & 510 & 49 & 101 & 94 \\ 1979 & 605 & 104 & 290 & 327 & 18 & 54 & 90 \\ 1980 & 554 & 40 & 294 & 243 & 64 & 56 & 80 \\ 1981 & 797 & 133 & 368 & 404 & 59 & 90 & 97 \\ 1982 & 750 & 129 & 395 & 442 & 37 & 134 & 107 \\ 1983 & 626 & 75 & 241 & 403 & 46 & 119 & 103 \\ 1984 & 724 & 130 & 263 & 413 & 100 & 172 & 87 \\ 1985 & 527 & 83 & 255 & 279 & 30 & 76 & 87 \\ 1986 & 539 & 34 & 289 & 288 & 18 & 65 & 96 \\ 1987 & 594 & 166 & 247 & 305 & 16 & 57 & 87 \\ 1988 & 670 & 52 & 329 & 348 & 80 & 115 & 96 \\ 1989 & 515 & 33 & 283 & 287 & 40 & 102 & 76 \\ 1990 & 587 & 41 & 190 & 300 & 50 & 26 & 85\end{array}$


11. Melléklet: Becsült Huglin- és Winkler-indexek, biológiailag hatásos hőösszegek, júliusi és januári átlaghőmérsékletek, valamint a tenyészidőszakok átlaghőmérséklete, átlagos maximum és minimum hömérséklete $\left[{ }^{\circ} \mathrm{C}\right] 2021$ és 2050 között

\begin{tabular}{crrrrrrrr} 
Ev & Huglin & Winkler & BEDD & \multicolumn{5}{c}{ MJuT MJaT GSAT GSATX GSATN } \\
2021 & 1616 & 1085 & 950 & 19 & 0 & 15 & 20 & 10 \\
2022 & 2268 & 1656 & 1267 & 23 & 3 & 17 & 24 & 12 \\
2023 & 1722 & 1186 & 1118 & 18 & 3 & 15 & 20 & 11 \\
2024 & 1804 & 1220 & 1060 & 21 & 1 & 15 & 21 & 10 \\
2025 & 2047 & 1517 & 1276 & 20 & 2 & 17 & 23 & 12 \\
2026 & 1725 & 1168 & 1035 & 17 & 2 & 15 & 20 & 10 \\
2027 & 1757 & 1189 & 1041 & 21 & 3 & 15 & 21 & 10 \\
2028 & 1901 & 1353 & 1215 & 19 & 4 & 16 & 22 & 11 \\
2029 & 1743 & 1289 & 1229 & 19 & 3 & 16 & 21 & 12 \\
2030 & 2150 & 1636 & 1323 & 21 & 2 & 17 & 24 & 12 \\
2031 & 2192 & 1582 & 1302 & 21 & 3 & 17 & 23 & 12 \\
2032 & 2007 & 1454 & 1199 & 22 & 2 & 16 & 23 & 11 \\
2033 & 2030 & 1530 & 1283 & 22 & 5 & 17 & 23 & 12 \\
2034 & 2198 & 1569 & 1235 & 25 & 1 & 17 & 23 & 12 \\
2035 & 2159 & 1578 & 1295 & 20 & 1 & 17 & 23 & 12 \\
2036 & 2135 & 1496 & 1229 & 22 & 0 & 16 & 22 & 11 \\
2037 & 2235 & 1617 & 1331 & 21 & 0 & 17 & 23 & 12 \\
2038 & 1663 & 1141 & 1058 & 20 & 3 & 15 & 20 & 11 \\
2039 & 1979 & 1383 & 1164 & 20 & 3 & 16 & 22 & 12 \\
2040 & 1885 & 1341 & 1165 & 21 & 4 & 16 & 22 & 12 \\
2041 & 2289 & 1632 & 1280 & 23 & 3 & 17 & 24 & 12 \\
2042 & 2266 & 1592 & 1240 & 23 & 3 & 17 & 23 & 11 \\
2043 & 2102 & 1501 & 1228 & 20 & 4 & 17 & 23 & 12 \\
2044 & 2142 & 1518 & 1190 & 23 & -1 & 17 & 23 & 12 \\
2045 & 1899 & 1329 & 1114 & 22 & 6 & 16 & 22 & 11 \\
2046 & 2175 & 1622 & 1325 & 21 & 7 & 17 & 23 & 13 \\
2047 & 1950 & 1411 & 1194 & 22 & 4 & 16 & 22 & 12 \\
2048 & 2357 & 1749 & 1342 & 25 & 6 & 18 & 24 & 13 \\
2049 & 2062 & 1453 & 1210 & 22 & 4 & 17 & 23 & 11 \\
2050 & 1900 & 1387 & 1177 & 22 & 2 & 16 & 22 & 12 \\
& & & & & & & &
\end{tabular}


12. Melléklet: A szüreti időszak maximum hőmérséklete (HMX), a téli minimum hőmérséklet (WMN), az érésidő átlaghőmérséklete (RAT), hideg éjszaka-index (CNI) és a kontinentális $(\mathrm{CO})$ hatás értékei $\left[{ }^{\circ} \mathrm{C}\right] 2021$ és 2050 között

$\begin{array}{cccccc}\text { Ev } & \text { HMX } & \text { WMN } & \text { RAT } & \text { CNI } & \text { CO } \\ 2021 & 23 & -16 & 14 & 9 & 19 \\ 2022 & 27 & -10 & 15 & 11 & 20 \\ 2023 & 23 & -11 & 14 & 12 & 15 \\ 2024 & 24 & -10 & 15 & 11 & 20 \\ 2025 & 25 & -8 & 16 & 10 & 18 \\ 2026 & 22 & -4 & 13 & 8 & 15 \\ 2027 & 24 & -10 & 15 & 10 & 19 \\ 2028 & 24 & -3 & 15 & 10 & 15 \\ 2029 & 22 & -5 & 16 & 12 & 17 \\ 2030 & 27 & -10 & 18 & 14 & 19 \\ 2031 & 26 & -5 & 18 & 13 & 18 \\ 2032 & 26 & -8 & 16 & 11 & 19 \\ 2033 & 26 & -5 & 17 & 11 & 17 \\ 2034 & 27 & -11 & 16 & 11 & 24 \\ 2035 & 25 & -7 & 16 & 12 & 19 \\ 2036 & 26 & -11 & 16 & 12 & 22 \\ 2037 & 26 & -11 & 18 & 13 & 21 \\ 2038 & 23 & -9 & 14 & 10 & 17 \\ 2039 & 25 & -4 & 16 & 13 & 17 \\ 2040 & 24 & -6 & 16 & 11 & 18 \\ 2041 & 26 & -7 & 15 & 10 & 20 \\ 2042 & 28 & -11 & 16 & 11 & 20 \\ 2043 & 26 & -10 & 15 & 10 & 16 \\ 2044 & 27 & -8 & 15 & 10 & 24 \\ 2045 & 24 & -9 & 14 & 9 & 15 \\ 2046 & 25 & -3 & 15 & 10 & 14 \\ 2047 & 24 & -10 & 15 & 10 & 18 \\ 2048 & 28 & -5 & 17 & 12 & 19 \\ 2049 & 26 & -7 & 16 & 12 & 18 \\ 2050 & 25 & -11 & 16 & 11 & 19\end{array}$


13. Melléklet: Az extrém meleg napok száma (NEHD), a meleg napok száma (NHD), a nyári napok száma (NSD), a fagyos napok száma (NFD), a jeges napok száma (NID), valamint a tavaszi (NSFD) és őszi (NFFD) fagyos napok száma 2021 és 2050 között

$\begin{array}{rrrrrrrrrr}\text { Ev } & \text { NEHD } & \text { NHD } & \text { NSD } & \text { NFD } & \text { NID } & \text { F15D } & \text { F8D } & \text { NSFD } & \text { NFFD } \\ 2021 & 0 & 15 & 48 & 69 & 8 & 1 & 14 & 25 & 0 \\ 2022 & 14 & 45 & 88 & 49 & 0 & 0 & 0 & 17 & 12 \\ 2023 & 0 & 2 & 54 & 41 & 1 & 0 & 3 & 3 & 8 \\ 2024 & 0 & 20 & 62 & 41 & 0 & 0 & 7 & 13 & 3 \\ 2025 & 2 & 31 & 70 & 47 & 0 & 0 & 1 & 17 & 10 \\ 2026 & 0 & 16 & 50 & 41 & 0 & 0 & 0 & 3 & 13 \\ 2027 & 1 & 17 & 55 & 35 & 0 & 0 & 0 & 5 & 0 \\ 2028 & 1 & 13 & 64 & 32 & 0 & 0 & 0 & 4 & 3 \\ 2029 & 0 & 4 & 36 & 33 & 1 & 0 & 1 & 11 & 11 \\ 2030 & 10 & 41 & 89 & 41 & 0 & 0 & 2 & 21 & 2 \\ 2031 & 4 & 32 & 89 & 40 & 0 & 0 & 0 & 8 & 2 \\ 2032 & 5 & 26 & 79 & 30 & 0 & 0 & 0 & 7 & 7 \\ 2033 & 9 & 25 & 70 & 28 & 0 & 0 & 0 & 7 & 2 \\ 2034 & 11 & 39 & 89 & 41 & 0 & 0 & 0 & 3 & 7 \\ 2035 & 7 & 27 & 77 & 30 & 0 & 0 & 0 & 0 & 14 \\ 2036 & 12 & 35 & 65 & 40 & 1 & 0 & 4 & 5 & 13 \\ 2037 & 9 & 32 & 85 & 46 & 1 & 0 & 3 & 7 & 2 \\ 2038 & 0 & 7 & 40 & 18 & 0 & 0 & 2 & 2 & 5 \\ 2039 & 4 & 25 & 68 & 34 & 0 & 0 & 0 & 8 & 7 \\ 2040 & 4 & 19 & 50 & 22 & 0 & 0 & 0 & 2 & 8 \\ 2041 & 18 & 41 & 100 & 21 & 0 & 0 & 0 & 5 & 3 \\ 2042 & 18 & 38 & 85 & 34 & 2 & 0 & 3 & 1 & 9 \\ 2043 & 8 & 34 & 79 & 18 & 0 & 0 & 0 & 7 & 9 \\ 2044 & 11 & 36 & 84 & 40 & 0 & 0 & 2 & 11 & 7 \\ 2045 & 7 & 24 & 75 & 25 & 0 & 0 & 0 & 12 & 9 \\ 2046 & 6 & 32 & 94 & 19 & 0 & 0 & 0 & 11 & 7 \\ 2047 & 4 & 23 & 69 & 35 & 0 & 0 & 0 & 16 & 14 \\ 2048 & 15 & 53 & 93 & 10 & 0 & 0 & 0 & 1 & 3 \\ 2049 & 8 & 27 & 80 & 31 & 0 & 0 & 0 & 12 & 0 \\ 2050 & 7 & 21 & 61 & 33 & 2 & 0 & 5 & 2 & 0\end{array}$


14. Melléklet: A Gladstones (SFIGlad) és a Wolf-Boyer féle (SFIWB) tavaszi fagyindex, a hőmérséklet (DR), az áprilisi átlagos napi hőingás (MADR), és a szüreti átlagos napi hőingás (MHDR), az érésidei napi hőingás összege (ET) és a Riberau-Gayon-Peynaud index (RGP) értékei $\left[{ }^{\circ} \mathrm{C}\right] 2021$ és 2050 között

$\begin{array}{cccccccc}\text { Ev } & \text { SFI_Glad } & \text { SFI_WB } & \text { DR } & \text { MADR } & \text { MHDR } & \text { ET } & \text { RGP } \\ 2021 & 12 & 4 & 25 & 8 & 10 & 1628 & 1391 \\ 2022 & 14 & 5 & 28 & 10 & 10 & 1727 & 2164 \\ 2023 & 13 & 5 & 20 & 10 & 8 & 1339 & 1180 \\ 2024 & 12 & 6 & 24 & 12 & 10 & 1586 & 1567 \\ 2025 & 13 & 6 & 23 & 11 & 10 & 1638 & 1935 \\ 2026 & 11 & 6 & 20 & 12 & 10 & 1479 & 1382 \\ 2027 & 12 & 5 & 25 & 10 & 11 & 1666 & 1502 \\ 2028 & 13 & 5 & 26 & 10 & 11 & 1632 & 1648 \\ 2029 & 10 & 6 & 18 & 12 & 9 & 1358 & 1459 \\ 2030 & 13 & 5 & 26 & 9 & 13 & 1921 & 2211 \\ 2031 & 15 & 5 & 26 & 11 & 12 & 1754 & 2053 \\ 2032 & 10 & 5 & 24 & 9 & 11 & 1804 & 1844 \\ 2033 & 12 & 5 & 30 & 11 & 10 & 1667 & 1948 \\ 2034 & 16 & 6 & 25 & 12 & 9 & 1639 & 1841 \\ 2035 & 12 & 6 & 26 & 12 & 9 & 1538 & 1792 \\ 2036 & 12 & 5 & 30 & 9 & 10 & 1704 & 1879 \\ 2037 & 14 & 6 & 32 & 12 & 11 & 1689 & 2049 \\ 2038 & 11 & 5 & 22 & 10 & 8 & 1412 & 1189 \\ 2039 & 12 & 5 & 23 & 10 & 9 & 1595 & 1721 \\ 2040 & 9 & 5 & 26 & 9 & 10 & 1615 & 1718 \\ 2041 & 15 & 6 & 28 & 12 & 9 & 1666 & 2058 \\ 2042 & 11 & 5 & 30 & 10 & 11 & 1892 & 2125 \\ 2043 & 11 & 4 & 26 & 9 & 10 & 1712 & 1959 \\ 2044 & 13 & 5 & 31 & 9 & 9 & 1712 & 1942 \\ 2045 & 8 & 5 & 26 & 10 & 9 & 1579 & 1664 \\ 2046 & 7 & 4 & 26 & 9 & 10 & 1610 & 1953 \\ 2047 & 10 & 5 & 28 & 9 & 9 & 1557 & 1741 \\ 2048 & 11 & 5 & 28 & 9 & 11 & 1827 & 2223 \\ 2049 & 13 & 5 & 27 & 11 & 11 & 1794 & 1986 \\ 2050 & 12 & 5 & 28 & 10 & 9 & 1511 & 1603\end{array}$


15. Melléklet: Csapadékindexek [mm]: éves (AR), nyári (SR), téli (WR) csapadékmennyiségek, a tenyészidőszak (GSR), a virágzás (BPR), az érési időszak (RPR) csapadékmennyisége, valamint a tenyészidőszak csapadékos napjainak száma (GSRD) 2021 és 2050 között

$\begin{array}{cccccccc}\text { Ev } & \text { AR } & \text { SR } & \text { WR } & \text { GSR } & \text { BPR } & \text { RPR } & \text { GSRD } \\ 2021 & 521 & 70 & 157 & 312 & 46 & 119 & 89 \\ 2022 & 533 & 64 & 165 & 233 & 19 & 127 & 68 \\ 2023 & 863 & 131 & 341 & 584 & 93 & 205 & 119 \\ 2024 & 670 & 56 & 317 & 316 & 28 & 163 & 88 \\ 2025 & 618 & 74 & 388 & 278 & 33 & 83 & 89 \\ 2026 & 621 & 157 & 253 & 412 & 45 & 117 & 85 \\ 2027 & 581 & 110 & 183 & 359 & 59 & 72 & 91 \\ 2028 & 766 & 61 & 261 & 397 & 35 & 67 & 88 \\ 2029 & 752 & 210 & 362 & 477 & 96 & 90 & 97 \\ 2030 & 404 & 32 & 187 & 209 & 37 & 26 & 67 \\ 2031 & 487 & 121 & 214 & 257 & 56 & 71 & 70 \\ 2032 & 521 & 127 & 238 & 330 & 47 & 72 & 70 \\ 2033 & 532 & 95 & 248 & 297 & 19 & 114 & 67 \\ 2034 & 664 & 71 & 222 & 432 & 52 & 232 & 79 \\ 2035 & 663 & 167 & 177 & 467 & 101 & 119 & 85 \\ 2036 & 562 & 33 & 199 & 306 & 44 & 76 & 82 \\ 2037 & 494 & 70 & 298 & 308 & 59 & 84 & 82 \\ 2038 & 721 & 199 & 117 & 579 & 153 & 218 & 107 \\ 2039 & 581 & 57 & 155 & 338 & 39 & 123 & 88 \\ 2040 & 475 & 109 & 267 & 302 & 50 & 60 & 95 \\ 2041 & 465 & 77 & 133 & 323 & 64 & 148 & 85 \\ 2042 & 475 & 57 & 188 & 223 & 16 & 30 & 74 \\ 2043 & 537 & 76 & 285 & 278 & 75 & 47 & 82 \\ 2044 & 537 & 46 & 170 & 287 & 20 & 107 & 87 \\ 2045 & 500 & 67 & 292 & 339 & 60 & 125 & 79 \\ 2046 & 689 & 69 & 211 & 380 & 55 & 132 & 86 \\ 2047 & 584 & 53 & 318 & 348 & 94 & 85 & 98 \\ 2048 & 434 & 89 & 120 & 307 & 46 & 87 & 71 \\ 2049 & 502 & 71 & 254 & 204 & 26 & 65 & 63 \\ 2050 & 754 & 149 & 290 & 438 & 78 & 151 & 88\end{array}$


16. Melléklet: Becsült Huglin- és Winkler-indexek, biológiailag hatásos hőösszegek, júliusi és januári átlaghőmérsékletek, valamint a tenyészidőszakok átlaghőmérséklete, átlagos maximum és minimum hömérséklete $\left[{ }^{\circ} \mathrm{C}\right] 2071$ és 2100 között

$\begin{array}{crrrrrrrr}\text { Ev } & \text { Huglin } & \text { Winkle } & \text { BEDD } & \text { MJuT } & \text { MJaT } & \text { GSAT } & \text { GSATX } & \text { GSATN } \\ 2071 & 2636 & 2058 & 1540 & 23 & 2 & 20 & 26 & 14 \\ 2072 & 2250 & 1681 & 1252 & 22 & 6 & 18 & 23 & 13 \\ 2073 & 2336 & 1720 & 1319 & 22 & 4 & 18 & 24 & 13 \\ 2074 & 2336 & 1774 & 1319 & 24 & 1 & 18 & 24 & 13 \\ 2075 & 2544 & 1918 & 1366 & 25 & 2 & 19 & 25 & 13 \\ 2076 & 2199 & 1652 & 1282 & 25 & 4 & 18 & 24 & 13 \\ 2077 & 2412 & 1799 & 1312 & 26 & 3 & 18 & 24 & 13 \\ 2078 & 2274 & 1789 & 1473 & 22 & 5 & 18 & 24 & 14 \\ 2079 & 2187 & 1740 & 1381 & 24 & 5 & 18 & 24 & 13 \\ 2080 & 2318 & 1773 & 1325 & 24 & 5 & 18 & 24 & 13 \\ 2081 & 2494 & 1874 & 1402 & 23 & 3 & 19 & 25 & 14 \\ 2082 & 2437 & 1854 & 1420 & 26 & 4 & 19 & 25 & 14 \\ 2083 & 2526 & 1950 & 1344 & 24 & 6 & 19 & 25 & 13 \\ 2084 & 2238 & 1723 & 1379 & 23 & 5 & 18 & 24 & 13 \\ 2085 & 2375 & 1804 & 1322 & 26 & 7 & 18 & 24 & 13 \\ 2086 & 2716 & 2119 & 1447 & 25 & 5 & 20 & 26 & 14 \\ 2087 & 2390 & 1814 & 1395 & 22 & 5 & 18 & 24 & 13 \\ 2088 & 2747 & 2120 & 1430 & 26 & 7 & 20 & 26 & 14 \\ 2089 & 2767 & 2140 & 1547 & 24 & 7 & 20 & 26 & 15 \\ 2090 & 2248 & 1781 & 1422 & 21 & 7 & 18 & 24 & 13 \\ 2091 & 2579 & 1996 & 1465 & 25 & 5 & 19 & 25 & 14 \\ 2092 & 2302 & 1751 & 1354 & 23 & 6 & 18 & 24 & 13 \\ 2093 & 2120 & 1544 & 1259 & 22 & 6 & 17 & 22 & 13 \\ 2094 & 2528 & 1944 & 1352 & 26 & -2 & 19 & 25 & 13 \\ 2095 & 2459 & 1876 & 1478 & 23 & 5 & 19 & 24 & 14 \\ 2096 & 2395 & 1786 & 1377 & 23 & -1 & 18 & 24 & 13 \\ 2097 & 2732 & 2047 & 1444 & 25 & 6 & 19 & 26 & 14 \\ 2098 & 2331 & 1736 & 1322 & 24 & 4 & 18 & 24 & 13 \\ 2099 & 3175 & 2462 & 1577 & 29 & 6 & 21 & 28 & 15 \\ 2100 & 2822 & 2159 & 1504 & 23 & 7 & 20 & 27 & 14\end{array}$


17. Melléklet: A szüreti időszak maximum hömérséklete (HMX), a téli minimum hőmérséklet (WMN), az érésidő átlagos hőmérséklete (RAT), hideg éjszaka-index (CNI) és a kontinentális (CO) hatás értékei [ $\left.{ }^{\circ} \mathrm{C}\right] 2071$ és 2100 között

$\begin{array}{cccccc}\text { Ev } & \text { HMX } & \text { WMN } & \text { RAT } & \text { CNI } & \text { CO } \\ 2071 & 29 & -5 & 21 & 15 & 21 \\ 2072 & 27 & -3 & 16 & 11 & 16 \\ 2073 & 28 & -4 & 18 & 14 & 18 \\ 2074 & 28 & -7 & 18 & 13 & 23 \\ 2075 & 30 & -5 & 20 & 16 & 23 \\ 2076 & 27 & -3 & 18 & 13 & 20 \\ 2077 & 29 & -7 & 16 & 11 & 24 \\ 2078 & 26 & -5 & 17 & 14 & 17 \\ 2079 & 27 & -7 & 19 & 13 & 20 \\ 2080 & 27 & -3 & 16 & 11 & 20 \\ 2081 & 28 & -6 & 18 & 15 & 20 \\ 2082 & 28 & -9 & 18 & 12 & 21 \\ 2083 & 30 & -3 & 20 & 15 & 19 \\ 2084 & 26 & -7 & 17 & 13 & 18 \\ 2085 & 29 & -8 & 18 & 14 & 19 \\ 2086 & 30 & -4 & 20 & 15 & 20 \\ 2087 & 28 & -6 & 19 & 16 & 17 \\ 2088 & 31 & -3 & 21 & 16 & 19 \\ 2089 & 30 & -3 & 19 & 14 & 17 \\ 2090 & 26 & -4 & 19 & 12 & 14 \\ 2091 & 28 & -3 & 18 & 15 & 21 \\ 2092 & 27 & -6 & 16 & 12 & 17 \\ 2093 & 26 & -4 & 16 & 12 & 16 \\ 2094 & 30 & -14 & 18 & 13 & 28 \\ 2095 & 27 & -4 & 17 & 14 & 18 \\ 2096 & 28 & -9 & 19 & 14 & 24 \\ 2097 & 30 & -4 & 20 & 16 & 19 \\ 2098 & 27 & -4 & 16 & 11 & 20 \\ 2099 & 32 & -6 & 19 & 14 & 22 \\ 2100 & 31 & -2 & 20 & 13 & 16\end{array}$


18. Melléklet: Az extrém meleg napok száma (NEHD), a meleg napok száma (NHD), a nyári napok száma (NSD), a fagyos napok száma (NFD), a jeges napok száma (NID), valamint a tavaszi (NSFD) és őszi (NFFD) fagyos napok száma 2071 és 2100 között

$\begin{array}{rrrrrrrrrr}\text { Ev } & \text { NEHD } & \text { NHD } & \text { NSD } & \text { NFD } & \text { NID } & \text { F15D } & \text { F8D } & \text { NSFD } & \text { NFFD } \\ 2071 & 20 & 56 & 118 & 32 & 0 & 0 & 0 & 2 & 3 \\ 2072 & 12 & 43 & 88 & 17 & 0 & 0 & 0 & 0 & 3 \\ 2073 & 15 & 49 & 90 & 28 & 0 & 0 & 0 & 8 & 0 \\ 2074 & 22 & 50 & 88 & 43 & 0 & 0 & 0 & 17 & 0 \\ 2075 & 22 & 63 & 111 & 42 & 0 & 0 & 0 & 12 & 1 \\ 2076 & 15 & 40 & 80 & 24 & 0 & 0 & 0 & 4 & 0 \\ 2077 & 25 & 49 & 94 & 27 & 0 & 0 & 0 & 5 & 3 \\ 2078 & 6 & 33 & 92 & 14 & 0 & 0 & 0 & 0 & 0 \\ 2079 & 9 & 35 & 87 & 35 & 0 & 0 & 0 & 20 & 3 \\ 2080 & 26 & 46 & 80 & 7 & 0 & 0 & 0 & 0 & 0 \\ 2081 & 14 & 49 & 107 & 26 & 0 & 0 & 0 & 0 & 1 \\ 2082 & 19 & 41 & 97 & 28 & 0 & 0 & 5 & 7 & 3 \\ 2083 & 21 & 64 & 112 & 19 & 0 & 0 & 0 & 7 & 0 \\ 2084 & 8 & 38 & 86 & 35 & 0 & 0 & 0 & 9 & 2 \\ 2085 & 21 & 54 & 99 & 40 & 0 & 0 & 0 & 15 & 0 \\ 2086 & 27 & 75 & 128 & 15 & 0 & 0 & 0 & 11 & 1 \\ 2087 & 8 & 44 & 96 & 11 & 0 & 0 & 0 & 1 & 2 \\ 2088 & 39 & 79 & 119 & 9 & 0 & 0 & 0 & 3 & 1 \\ 2089 & 23 & 63 & 127 & 12 & 0 & 0 & 0 & 2 & 0 \\ 2090 & 8 & 35 & 100 & 4 & 0 & 0 & 0 & 0 & 5 \\ 2091 & 14 & 55 & 108 & 13 & 0 & 0 & 0 & 2 & 2 \\ 2092 & 13 & 42 & 90 & 15 & 0 & 0 & 0 & 2 & 0 \\ 2093 & 4 & 28 & 80 & 13 & 0 & 0 & 0 & 7 & 2 \\ 2094 & 31 & 62 & 103 & 44 & 5 & 0 & 6 & 3 & 5 \\ 2095 & 9 & 41 & 96 & 13 & 0 & 0 & 0 & 2 & 3 \\ 2096 & 13 & 54 & 100 & 34 & 0 & 0 & 1 & 0 & 2 \\ 2097 & 28 & 58 & 117 & 21 & 0 & 0 & 0 & 9 & 0 \\ 2098 & 15 & 49 & 98 & 19 & 0 & 0 & 0 & 1 & 2 \\ 2099 & 46 & 93 & 139 & 25 & 0 & 0 & 0 & 2 & 1 \\ 2100 & 25 & 89 & 129 & 5 & 0 & 0 & 0 & 1 & 4\end{array}$


19. Melléklet: A Gladstones (SFIGlad) és a Wolf-Boyer féle (SFIWB) tavaszi fagyindex, a júliusi hőmérsékleti terjedelem (DR), az áprilisi átlagos napi hőingás (MADR), és a szüreti átlagos napi hőingás (MHDR), érésidei napi hőingás összege (ET) és a Riberau-Gayon-Peynaud index (RGP) értékei $\left[{ }^{\circ} \mathrm{C}\right] 2071$ és 2100 között

$\begin{array}{cccccccc}\text { Ev } & \text { SFI_Glad } & \text { SFI_WB } & \text { DR } & \text { MADR } & \text { MHDR } & \text { ET } & \text { RGP } \\ 2071 & 13 & 6 & 32 & 11 & 14 & 1901 & 2690 \\ 2072 & 11 & 4 & 25 & 8 & 10 & 1686 & 1977 \\ 2073 & 9 & 5 & 28 & 9 & 12 & 1849 & 2320 \\ 2074 & 9 & 5 & 28 & 10 & 10 & 1691 & 2004 \\ 2075 & 12 & 5 & 27 & 10 & 12 & 1815 & 2368 \\ 2076 & 9 & 4 & 26 & 8 & 11 & 1759 & 2080 \\ 2077 & 15 & 6 & 31 & 11 & 11 & 1824 & 2161 \\ 2078 & 13 & 5 & 29 & 11 & 9 & 1550 & 2041 \\ 2079 & 8 & 4 & 28 & 9 & 11 & 1738 & 2200 \\ 2080 & 13 & 5 & 34 & 10 & 8 & 1652 & 2099 \\ 2081 & 10 & 5 & 23 & 10 & 10 & 1679 & 2350 \\ 2082 & 9 & 5 & 26 & 10 & 12 & 1728 & 2275 \\ 2083 & 10 & 5 & 25 & 10 & 11 & 1827 & 2442 \\ 2084 & 12 & 5 & 23 & 9 & 9 & 1578 & 2075 \\ 2085 & 12 & 4 & 31 & 7 & 12 & 1876 & 2282 \\ 2086 & 12 & 4 & 28 & 7 & 12 & 1889 & 2585 \\ 2087 & 13 & 4 & 24 & 8 & 10 & 1660 & 2122 \\ 2088 & 11 & 4 & 27 & 9 & 11 & 1848 & 2603 \\ 2089 & 10 & 6 & 26 & 11 & 10 & 1720 & 2483 \\ 2090 & 13 & 5 & 21 & 9 & 11 & 1645 & 2053 \\ 2091 & 9 & 6 & 26 & 11 & 9 & 1664 & 2369 \\ 2092 & 10 & 5 & 25 & 10 & 9 & 1584 & 2000 \\ 2093 & 8 & 3 & 25 & 7 & 9 & 1518 & 1747 \\ 2094 & 11 & 5 & 28 & 9 & 11 & 1763 & 2320 \\ 2095 & 13 & 5 & 27 & 9 & 10 & 1603 & 2259 \\ 2096 & 9 & 5 & 29 & 9 & 11 & 1771 & 2158 \\ 2097 & 10 & 5 & 34 & 11 & 11 & 1752 & 2465 \\ 2098 & 12 & 5 & 26 & 11 & 10 & 1677 & 2176 \\ 2099 & 12 & 7 & 31 & 13 & 12 & 1913 & 3084 \\ 2100 & 11 & 5 & 31 & 10 & 13 & 1991 & 2834\end{array}$


20. Melléklet: Csapadékindexek [mm]: éves (AR), nyári (SR), téli (WR) csapadékmennyiségek, a tenyészidőszak (GSR), a virágzás (BPR), az érési időszak (RPR) csapadékmennyisége, valamint a tenyészidőszak csapadékos napjainak száma (GSRD) 2071 és 2100 között

$\begin{array}{ccccccccc}\text { Ev } & \text { RGP } & \text { AR } & \text { SR } & \text { WR } & \text { GSR } & \text { BPR } & \text { RPR } & \text { GSRD } \\ 2071 & 2690 & 472 & 119 & 188 & 189 & 89 & 18 & 57 \\ 2072 & 1977 & 615 & 102 & 232 & 393 & 56 & 118 & 89 \\ 2073 & 2320 & 285 & 43 & 131 & 182 & 31 & 67 & 71 \\ 2074 & 2004 & 690 & 110 & 198 & 470 & 86 & 226 & 96 \\ 2075 & 2368 & 556 & 61 & 244 & 316 & 22 & 122 & 67 \\ 2076 & 2080 & 651 & 28 & 288 & 305 & 16 & 58 & 79 \\ 2077 & 2161 & 584 & 48 & 261 & 387 & 46 & 147 & 79 \\ 2078 & 2041 & 728 & 146 & 189 & 451 & 44 & 169 & 81 \\ 2079 & 2200 & 504 & 22 & 241 & 285 & 44 & 56 & 73 \\ 2080 & 2099 & 646 & 33 & 251 & 373 & 3 & 195 & 67 \\ 2081 & 2350 & 585 & 47 & 316 & 268 & 29 & 61 & 79 \\ 2082 & 2275 & 694 & 67 & 417 & 338 & 90 & 70 & 76 \\ 2083 & 2442 & 533 & 88 & 247 & 267 & 40 & 78 & 58 \\ 2084 & 2075 & 630 & 107 & 281 & 362 & 92 & 147 & 73 \\ 2085 & 2282 & 567 & 43 & 243 & 287 & 58 & 90 & 72 \\ 2086 & 2585 & 507 & 74 & 230 & 321 & 41 & 39 & 77 \\ 2087 & 2122 & 704 & 96 & 346 & 388 & 103 & 73 & 91 \\ 2088 & 2603 & 499 & 65 & 108 & 292 & 21 & 121 & 79 \\ 2089 & 2483 & 738 & 79 & 261 & 449 & 26 & 160 & 76 \\ 2090 & 2053 & 828 & 172 & 372 & 455 & 110 & 72 & 85 \\ 2091 & 2369 & 716 & 35 & 335 & 367 & 42 & 117 & 83 \\ 2092 & 2000 & 852 & 42 & 393 & 450 & 71 & 169 & 86 \\ 2093 & 1747 & 792 & 66 & 411 & 431 & 30 & 85 & 101 \\ 2094 & 2320 & 719 & 75 & 319 & 354 & 11 & 101 & 69 \\ 2095 & 2259 & 590 & 90 & 348 & 350 & 13 & 140 & 80 \\ 2096 & 2158 & 643 & 31 & 258 & 367 & 54 & 156 & 66 \\ 2097 & 2465 & 627 & 130 & 263 & 344 & 57 & 124 & 68 \\ 2098 & 2176 & 499 & 33 & 202 & 288 & 19 & 117 & 72 \\ 2099 & 3084 & 448 & 37 & 174 & 244 & 11 & 52 & 56 \\ 2100 & 2834 & 527 & 90 & 278 & 197 & 22 & 24 & 47\end{array}$


21. Melléklet: Tenyészidőszakok Helvécián 2000-2004 között

\begin{tabular}{|l|c|c|c|c|c|c|c|c|}
\hline & \multicolumn{3}{|c|}{ I. módszer } & \multicolumn{3}{c|}{ II. módszer } & \multicolumn{3}{c|}{ I. módszer } & \multicolumn{2}{c|}{ II. módszer } \\
\hline Helvécia & \multicolumn{3}{|c|}{ Tenyészidő kezdete } & \multicolumn{3}{c|}{ Tenyészidő vége } \\
\hline Év & Dátum & JD & Dátum & JD & Dátum & JD & Dátum & JD \\
\hline 2000 & 04.12. & 103 & 03.31. & 91 & 10.10. & 284 & 11.14. & 324 \\
\hline 2001 & 04.19 & 109 & 04.10. & 100 & 10.24. & 297 & 12.01 & 336 \\
\hline 2002 & 04.13. & 103 & 04.05. & 95 & 09.25. & 268 & 10.20. & 293 \\
\hline 2003 & 04.22 & 112 & 04.16 & 106 & 10.06 & 280 & 10.10. & 284 \\
\hline 2004 & 05.10. & 130 & 04.07. & 98 & 10.10. & 284 & 11.03. & 313 \\
\hline
\end{tabular}


22. Melléklet: Tenyészidőszakok Kecskeméten 1977-2003 között

\begin{tabular}{|c|c|c|c|c|c|c|c|c|}
\hline \multirow{2}{*}{ Kecskemét } & \multicolumn{2}{|c|}{ I. módszer } & \multicolumn{2}{|c|}{ II. módszer } & \multicolumn{2}{|c|}{ I. módszer } & \multicolumn{2}{|c|}{ II. módszer } \\
\hline & \multicolumn{4}{|c|}{ Tenyészidő kezdete } & \multicolumn{4}{|c|}{ Tenyészidő vége } \\
\hline Év & Dátum & JD & Dátum & JD & Dátum & JD & Dátum & JD \\
\hline 1977 & 04.22 . & 111 & 04.19. & 109 & 11.13. & 315 & 11.05. & 287 \\
\hline 1978 & 05.15 . & 136 & 04.10. & 100 & 10.25 . & 298 & 10.23. & 286 \\
\hline 1979 & 05.14. & 134 & 04.12. & 102 & 10.18. & 291 & 10.12. & 285 \\
\hline 1980 & 05.15 . & 136 & 04.23. & 114 & 10.19. & 293 & 10.24 . & 298 \\
\hline 1981 & 05.06. & 115 & 04.04. & 94 & 11.03. & 305 & 10.29. & 302 \\
\hline 1982 & 05.02 . & 122 & 04.27. & 117 & 10.28. & 301 & 10. 23. & 286 \\
\hline 1983 & 04.17. & 107 & 03.29. & 88 & 10.20. & 293 & 10.18. & 291 \\
\hline 1984 & 05.12. & 133 & 04.09. & 100 & 10.27. & 301 & 10.31. & 305 \\
\hline 1985 & 05.05 . & 125 & 04.07. & 97 & 10.12. & 285 & 10.17. & 290 \\
\hline 1986 & 04.21. & 111 & 04.04. & 94 & 10. 23. & 296 & 10.18. & 291 \\
\hline 1987 & 05.24. & 144 & 04.11. & 101 & 10. 26. & 299 & 10.23. & 296 \\
\hline 1988 & 04.27. & 118 & 04.12. & 103 & 10. 18. & 292 & 10. 16. & 290 \\
\hline 1989 & 05.02. & 122 & 03.25 . & 84 & 11.06. & 308 & 10.24. & 297 \\
\hline 1990 & 04.24 & 114 & 03.28. & 87 & 10. 20. & 293 & 10. 22. & 295 \\
\hline 1991 & 05.25 . & 145 & 04.18. & 108 & 10.18. & 291 & 10.15. & 288 \\
\hline 1992 & 04.21. & 112 & 04.01. & 92 & 10. 28. & 301 & 10.15. & 289 \\
\hline 1993 & 04.15. & 105 & 04.07. & 97 & 10. 25. & 298 & 11.06. & 288 \\
\hline 1994 & 04. 20. & 110 & 03.23. & 82 & 10.05. & 278 & 10.17. & 290 \\
\hline 1995 & 05.16. & 136 & 04.05 . & 95 & 10. 21. & 294 & 12.01. & 333 \\
\hline 1996 & 04.17. & 108 & 04.08. & 99 & 10.19. & 293 & 12.03. & 336 \\
\hline 1997 & 04. 27. & 117 & 04.08. & 98 & 10. 13. & 286 & 10. 16. & 289 \\
\hline 1998 & 04.15. & 105 & 05.11. & 131 & 10. 26. & 299 & 11.09. & 291 \\
\hline 1999 & 05.06. & 126 & 04.03. & 93 & 11.07. & 309 & 10.24. & 297 \\
\hline 2000 & 04.11. & 102 & 03.27. & 87 & 10. 20. & 294 & 12. 21. & 354 \\
\hline 2001 & 04.24. & 114 & 03.25 . & 84 & 10. 24. & 297 & 12.01. & 333 \\
\hline 2002 & 04.14. & 104 & 03.27. & 86 & 10.30. & 303 & 10.23. & 286 \\
\hline 2003 & 04. 12. & 102 & 04. 07. & 97 & 10. 12. & 285 & 10. 10. & 283 \\
\hline
\end{tabular}


23. Melléklet: A korai fajták és klónjainak megfigyelt rügyfakadási időpontjai a kétféle módszerrel számított tenyészidőszak kezdeteihez viszonyítva Helvécián

\begin{tabular}{|r|r|r|l|l|l|l|l|r|}
\hline Helvécia & Teny.i.kezd. I. m. & Teny.i.kezd. II. m. & Ch & Ch75 & Ch96 & Szb & Szb34 & Szb52 \\
\hline 2000 & április 12. & március 31. & április 19. & április 19. & április 21. & április 25. & április 25. & április 25. \\
\hline 2001 & április 19. & április 10. & április 26. & április 28. & április 26. & április 30. & április 29. & május 1. \\
\hline 2002 & április 13. & április 5. & április 23. & április 23. & április 24. & április 29. & április 29. & április 30. \\
\hline 2003 & április 22. & április 16. & április 28. & április 28. & április 28. & április 30. & május 1. & április 30. \\
\hline 2004 & május 10. & április 7. & április 28. & április 29. & április 29. & április 26. & április 29. & április 28. \\
\hline
\end{tabular}

24. Melléklet: A közepes érésü Pinot blanc klónok megfigyelt rügyfakadási időpontjai a kétféle módszerrel számított tenyészidőszak kezdeteihez viszonyítva Helvécián

\begin{tabular}{|r|r|r|r|r|r|}
\hline Helvécia & Teny.i.kezd. I. m. & Teny.i.kezd. II. m. & Pb54 & Pb55 & PbD55 \\
\hline 2000 & április 12. & március 31. & április 21. & április 25. & április 25. \\
\hline 2001 & április 19. & április 10. & április 25. & április 26. & április 26. \\
\hline 2002 & április 13. & április 5. & április 23. & április 24. április 22. \\
\hline 2003 & április 22. & április 16. & április 30. & április 30. április 29. \\
\hline 2004 & május 10. & április 7. & április 27. & április 30. április 29. \\
\hline
\end{tabular}

25. Melléklet: A kései érésű Rajnai rizling és Hárslevelü klónok megfigyelt rügyfakadási időpontjai a kétféle módszerrel számított tenyészidőszak kezdeteihez viszonyítva Helvécián

\begin{tabular}{|r|r|r|r|r|r|r|r|r|}
\hline Helvécia Teny.i.kezd. I. m. & Teny.i.kezd. II. m. & RfRr239 & RfRr378 & RfRr391 & $R f R r 49$ & $R f H I P .4$ & $R f H I K .9$ \\
\hline 2000 & április 12. & március 31. & április 25. & április 25. & április 25. & április 25. április 25. április 25. \\
\hline 2001 & április 19. & április 10. & április 30. & május 1. & május 1. & május 1. április 30. április 30. \\
\hline 2002 & április 13. & április 5. & április 25. & április 27. & április 24. & április 27. április 26. április 26. \\
\hline 2003 & április 22. & április 16. & április 30. & április 30. & április 30. & április 30. & április 30. április 29. \\
\hline 2004 & május 10. & április 7. & május 4. & május 3. & május 3. & április 29. & május 1. & május 1. \\
\hline
\end{tabular}

